Supporting Information

\title{
Regio- and Enantioselective Synthesis of Azole Hemiaminal Esters by Lewis-Base-Catalyzed Dynamic Kinetic Resolution
}

David W. Piotrowski, ${ }^{*}$ Adam S. Kamlet, ${ }^{*}$ Anne-Marie Dechert Schmitt, Jiangli Yan,

Thomas Brandt, Jun Xiao, Liuqing Wei, Mark T. Barrila

Worldwide Medicinal Chemistry, Pfizer Inc.

Eastern Point Road, Groton, Connecticut, 06340 USA

E-mail: david.w.piotrowski@pfizer.com, adam.kamlet@pfizer.com 


\section{Table of Contents}

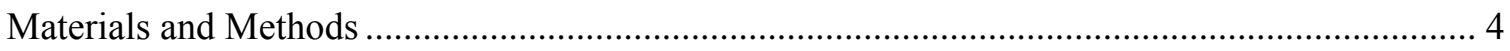

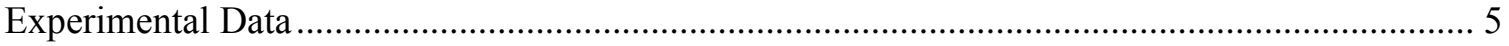

Alkylation of 5-phenyl-1H-tetrazole with 1-chloroethyl ethyl carbonate ................................. 5

Ethyl (1-(5-phenyl-2H-tetrazol-2-yl)ethyl) carbonate (Table 1, 2a) .................................... 5

Ethyl (1-(5-phenyl-1 $H$-tetrazol-1-yl)ethyl) carbonate (Table 1, 2b) .................................... 5

Experimental procedures for synthesis of 2,5-disubstituted tetrazoles (Table 1) ...................... 6

Ethyl (1-(5-phenyl-2H-tetrazol-2-yl)ethyl) carbonate (Table 1, 2a) ..................................... 6

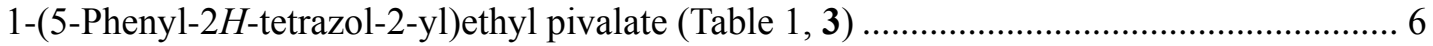

Ethyl (2-methyl-1-(5-phenyl-2H-tetrazol-2-yl)propyl) carbonate (Table 1, 4) ..................... 7

Methyl 2-(1-((ethoxycarbonyl)oxy)ethyl)-2H-tetrazole-5-carboxylate (Table 1, 5) .............. 7

1-(5-(tert-Butyl)-2H-tetrazol-2-yl)ethyl ethyl carbonate (Table 1, 6) .................................. 8

Ethyl (1-(5-(4-iodo-1-methyl-1H-pyrazol-5-yl)-2H-tetrazol-2-yl)ethyl) carbonate (Table 1,

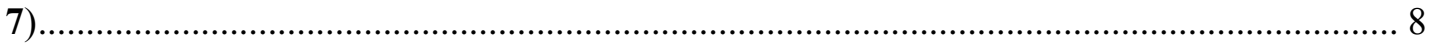

1-(5-Phenyl-2H-tetrazol-2-yl)cyclobutyl isobutyrate (Table 1, 8) ..................................... 9

(4-bromophenyl)(5-phenyl-2H-tetrazol-2-yl)methyl isobutyrate (Table 1, 9) ...................... 10

1-(5-Phenyl-2H-tetrazol-2-yl)ethyl 4-methylbenzenesulfonate (Table 1, 10) ...................... 10

1-(5-Phenyl-2H-tetrazol-2-yl)ethyl methanesulfonate (S-1) ............................................... 11

Elaboration of sulfonate ester products (Table 2) ..................................................................11

2-Ethyl-5-phenyl-2H-tetrazole (Table 2, 11) ...................................................................... 11

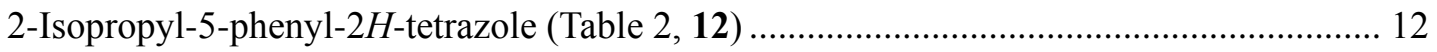

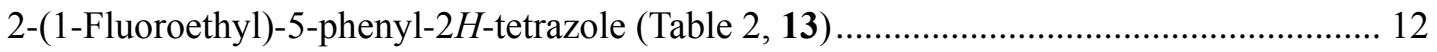

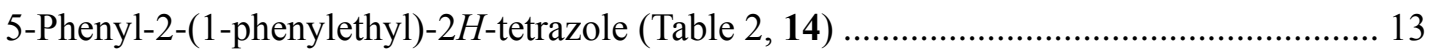

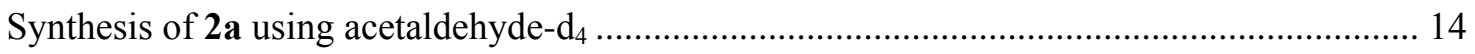

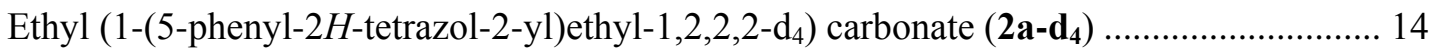

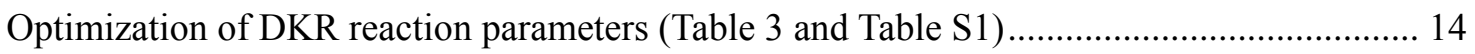

Table S1. Catalyst, base, solvent, and temperature variation ............................................. 16

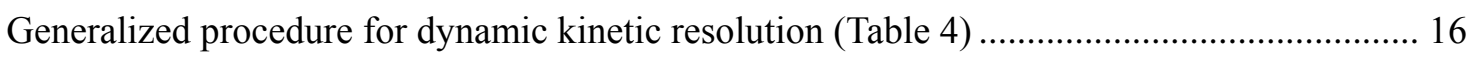

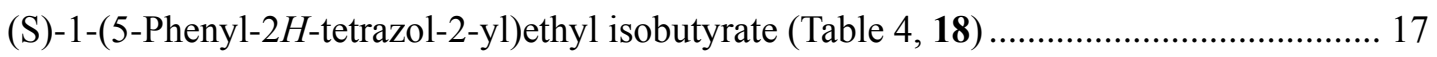

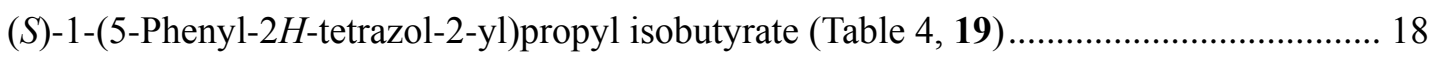

(S)-2-Methyl-1-(5-phenyl-2H-tetrazol-2-yl)propyl isobutyrate (Table 4, 20) ....................... 18

(S)-Phenyl(5-phenyl-2H-tetrazol-2-yl)methyl isobutyrate (Table 4, 21)............................ 19 


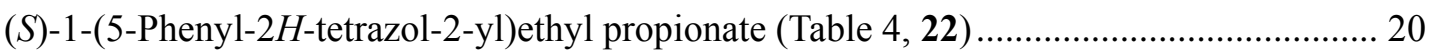

(S)-Ethyl (1-(5-phenyl-2H-tetrazol-2-yl)ethyl) carbonate (Table 4, 23 ((S)-2a))................. 21

(S)-(4-Bromophenyl)(5-phenyl-2H-tetrazol-2-yl)methyl isobutyrate (Table 4, 24 ((S)-9)) .. 21

(S)-(3'-Fluoro-4'-nitro-[1,1'-biphenyl]-4-yl)(5-phenyl-2H-tetrazol-2-yl)methyl isobutyrate

(S)-Ethyl (1-(5-(4-iodo-1-methyl-1H-pyrazol-5-yl)-2H-tetrazol-2-yl)ethyl) carbonate (Table 4, $25((S)-7))$.

(S)-2-Methyl-1-(5-(4'-methyl-[1,1'-biphenyl]-2-yl)-2H-tetrazol-2-yl)propyl isobutyrate (Table 4, 26). 24

(S)-1-(4-Phenyl-1H-pyrazol-1-yl)ethyl isobutyrate (Table 4, 27) ...................................... 25

(S)-1-(3-Phenyl-1H-pyrazol-1-yl)ethyl isobutyrate (Table 4, 28) ....................................... 26

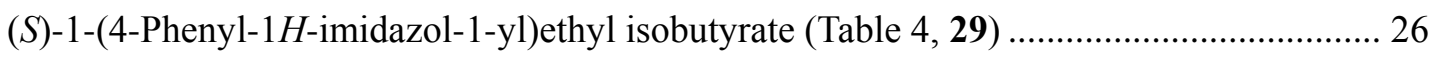

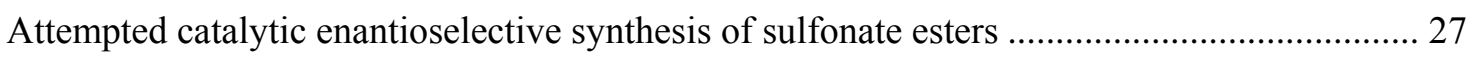

Formation of sulfonate ester $\mathbf{1 0}$ using stoichiometric chiral catalyst .................................... 28

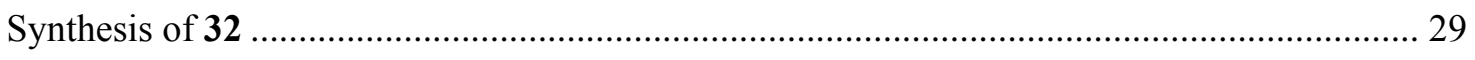

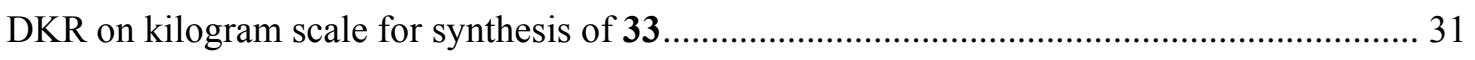

(S)-1-(5-(4-Iodo-1-methyl-1H-pyrazol-5-yl)-2H-tetrazol-2-yl)ethyl isobutyrate (Scheme 3, 33). 31

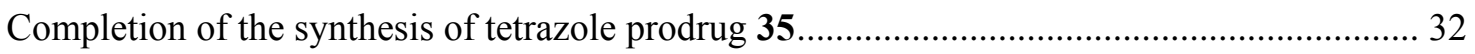

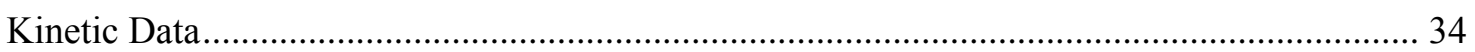

Equilibrium data for 5-phenyl- $1 H$-tetrazole and acetaldehyde: ${ }^{1} \mathrm{H}$ NMR .............................. 34

Figure S1: ${ }^{1} \mathrm{H}$ NMR spectra of $5 \mathrm{mM} 5$-phenyl- $1 H$-tetrazole and $100 \mathrm{mM}$ acetaldehyde in

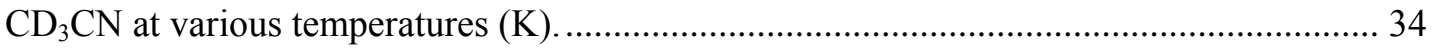

Figure S2: Kinetic data of 5-phenyl- $1 H$-tetrazole and acetaldehyde in $\mathrm{CD}_{3} \mathrm{CN}$ determined by

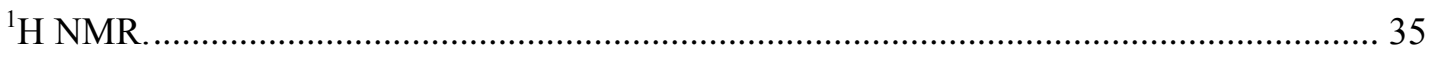

Equilibrium data for 5-(4'-methyl-[1,1'-biphenyl]-2-yl)-2H-tetrazole (15) and

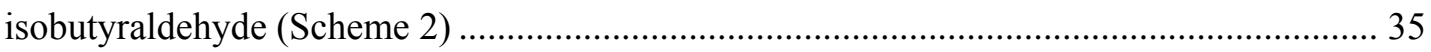

Figure S3: ${ }^{1} \mathrm{H}$ NMR spectra of $5 \mathrm{mM}$ 5-(4'-methyl-[1,1'-biphenyl]-2-yl)-2H-tetrazole (15)

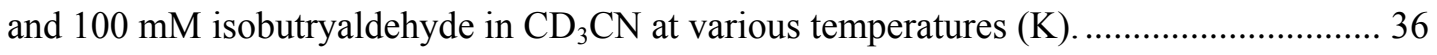

Table S2: NMR data observed for reaction of 5-(4'-methyl-[1,1'-biphenyl]-2-yl)-2H-tetrazole

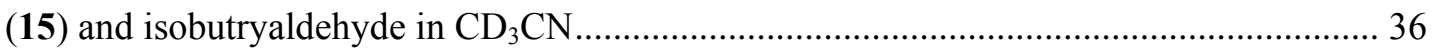

Figure S4: The exponential relationship of $K_{\text {eq }}$ to the temperature for the reaction of 5-(4'methyl-[1,1'-biphenyl]-2-yl)-2H-tetrazole (15) and isobutryaldehyde in $\mathrm{CD}_{3} \mathrm{CN}$. ............... 37

X-ray crystal structure of ethyl (1-(5-phenyl-1H-tetrazol-1-yl)ethyl) carbonate (2b) .............. 38

Figure S5. ORTEP drawing of ethyl (1-(5-phenyl-1H-tetrazol-1-yl)ethyl) carbonate (2b) .. 38 
Table S3. Crystal data and structure refinement for ethyl (1-(5-phenyl-1H-tetrazol-1yl)ethyl) carbonate (2b) 38

X-ray crystal structure of $(S)$-(3'-fluoro-4'-nitro-[1,1'-biphenyl]-4-yl)(5-phenyl-2 $H$-tetrazol-2yl)methyl isobutyrate (S-2).

Figure S6. ORTEP drawing of $(S)$-(3'-fluoro-4'-nitro-[1,1'-biphenyl]-4-yl)(5-phenyl-2Htetrazol-2-yl)methyl isobutyrate (S-2)....

Table S4. Crystal data and structure refinement for $(S)$-(3'-fluoro-4'-nitro-[1,1'-biphenyl]-4yl)(5-phenyl-2H-tetrazol-2-yl)methyl isobutyrate (S-2).

X-ray crystal structure of $(S)$-ethyl 1-[5-(4-iodo-1-methyl-1H-pyrazol-5-yl)-2 $H$-tetrazol-2yl]ethyl carbonate (25)

Figure S7. ORTEP drawing of (S)-ethyl 1-[5-(4-iodo-1-methyl-1H-pyrazol-5-yl)-2Htetrazol-2-yl] ethyl carbonate (25).

Table S5. Crystal data and structure refinement for (S)-ethyl 1-[5-(4-iodo-1-methyl-1H-

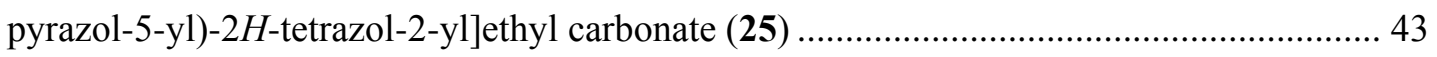

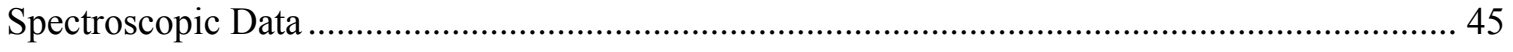

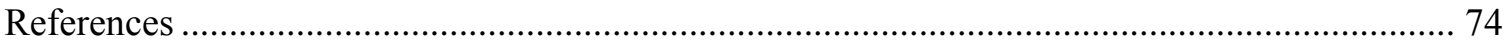




\section{Materials and Methods}

All chemicals, reagents, and solvents were purchased from commercial sources when available and used without further purification. Air- and moisture-insensitive reactions were carried out under an ambient atmosphere, magnetically stirred, and monitored by thin layer chromatography (TLC) using pre-coated Whatman $250 \mu \mathrm{m}$ silica gel plates and visualized by fluorescence quenching under UV light. Air- and moisture-sensitive reactions were carried out as described in Experimental Data. Silica gel chromatography was performed using an ISCO system using ISCO pre-packaged columns. Concentration under reduced pressure (in vacuo) was performed by rotary evaporation at appropriate temperature and pressure. Purified compounds were further dried under high vacuum to remove residual solvent. Yields refer to purified compounds. NMR spectra were recorded with a Bruker Avance III spectrometer using a $5 \mathrm{~mm}$ BBFO probe at 400 $\mathrm{MHz}$ and $101 \mathrm{MHz}$ for ${ }^{1} \mathrm{H}$ and ${ }^{13} \mathrm{C}$ acquisitions, respectively or with an Agilent DD2 spectrometer using a Protasis microflow probe at $600 \mathrm{MHz}$ and $151 \mathrm{MHz}$ for ${ }^{1} \mathrm{H}$ and ${ }^{13} \mathrm{C}$ acquisitions, respectively. Chemical shifts were referenced to the residual ${ }^{1} \mathrm{H}$ solvent signals $\left(\mathrm{CDCl}_{3}, \delta\right.$ 7.26) and solvent ${ }^{13} \mathrm{C}$ signals $\left(\mathrm{CDCl}_{3}, \delta 77.16\right) .{ }^{1}$ Signals are listed as follows: chemical shift in $\mathrm{ppm}$ (multiplicity identified as $\mathrm{s}=$ singlet, $\mathrm{d}=$ doublet, $\mathrm{t}=$ triplet, $\mathrm{q}=$ quartet, $\mathrm{m}=$ multiplet, $\mathrm{br}=$ broad; coupling constants in $\mathrm{Hz}$; integration). Melting points of solid compounds were obtained on a Buchi B-545 melting point apparatus. High resolution mass spectrometry (HRMS) was performed via atmospheric pressure chemical ionization (APCI) or electron scatter ionization (ESI) sources.

SFC method for determining enantiomeric ratio (column size: $250 \mathrm{~mm}$ x $4.6 \mathrm{~mm}$; type of column used for individual samples noted in text):

\section{Gradient: A: $\mathrm{CO} 2$ \\ B: Methanol}

\begin{tabular}{|c|c|c|}
\hline Time $(\mathrm{min})$ & $\% \mathrm{~A}$ & $\% \mathrm{~B}$ \\
\hline 0.00 & 95 & 5 \\
\hline 1.00 & 95 & 5 \\
\hline 9.00 & 40 & 60 \\
\hline 9.50 & 40 & 60 \\
\hline 10.0 & 95 & 5 \\
\hline
\end{tabular}

Backpressure: 120 Bar

Detection: $210 \mathrm{~nm}$

Flow: $\quad 3.0 \mathrm{~mL} / \mathrm{min}$ 


\section{Experimental Data}

\section{Alkylation of 5-phenyl-1H-tetrazole with 1-chloroethyl ethyl carbonate}

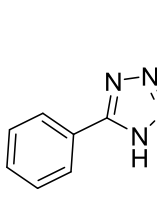

1

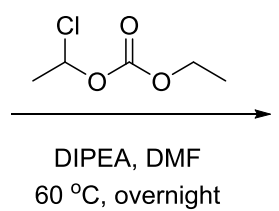

$60^{\circ} \mathrm{C}$, overnight

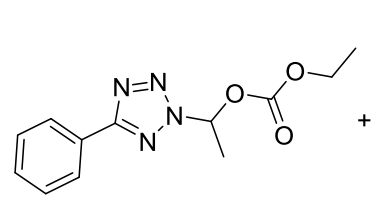

2a, $71 \%$

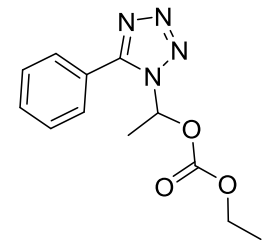

2b, $12 \%$

A round-bottom flask was charged with 5-phenyl-1H-tetrazole (1) $(774 \mathrm{mg}, 5.30 \mathrm{mmol}, 1.00$ equiv), DMF (15 mL), DIPEA (9.32 mL, $53.0 \mathrm{mmol}, 10.0$ equiv), and finally 1-chloroethyl ethyl carbonate $\left(4.27 \mathrm{~mL}, 31.8 \mathrm{mmol}, 6.00\right.$ equiv). The reaction mixture was heated at $60{ }^{\circ} \mathrm{C}$ overnight. The reaction mixture was cooled and concentrated in vacuo to remove volatiles and solvent. The residue was diluted with EtOAc and washed with $0.5 \mathrm{~N} \mathrm{HCl}$ aqueous solution three times, then washed with $4 \% \mathrm{MgSO}_{4}$ aqueous solution and brine. The organic layer was dried over $\mathrm{MgSO}_{4}$, filtered, and concentrated in vacuo. The residue was purified by silica gel chromatography (gradient of 0-30\% EtOAc in heptane (v/v)) to afford $991 \mathrm{mg}$ ( $71 \%$ yield) of ethyl (1-(5-phenyl-2H-tetrazol-2-yl)ethyl) carbonate (2a) as an oil and $162 \mathrm{mg}$ (12\% yield) of ethyl (1-(5-phenyl-1H-tetrazol-1-yl)ethyl) carbonate (2b) as a colorless solid.

\section{Ethyl (1-(5-phenyl-2H-tetrazol-2-yl)ethyl) carbonate (Table 1, 2a)}

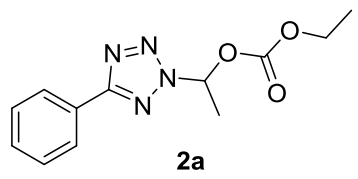

$\mathrm{R}_{f}=0.23$ (heptane/EtOAc 9:1 (v/v)). NMR Spectroscopy: ${ }^{1} \mathrm{H}$ NMR (400 MHz, $\left.\mathrm{CDCl}_{3}, 25{ }^{\circ} \mathrm{C}, \delta\right)$ : 8.20-8.16 (m, 2H), 7.50-7.47 (m, 3H), 7.24 (q, $J=6.3 \mathrm{~Hz}, 1 \mathrm{H}), 4.29-4.21$ (m, 2H), 2.06 (d, $J=6.2$ $\mathrm{Hz}, 3 \mathrm{H}), 1.31$ (t, $J=7.0 \mathrm{~Hz}, 3 \mathrm{H}) .{ }^{13} \mathrm{C} \mathrm{NMR}\left(101 \mathrm{MHz}, \mathrm{CDCl}_{3}, 25{ }^{\circ} \mathrm{C}, \delta\right): 165.5,153.1,130.7$, 129.0, 127.2, 127.1, 83.1, 65.4, 19.5, 14.2. IR (thin film, $\mathrm{cm}^{-1}$ ): 1756, 1450, 1247, 1113, 1092, 1038, 733, 693. HRMS (m/z): calculated for $\mathrm{C}_{12} \mathrm{H}_{15} \mathrm{~N}_{4} \mathrm{O}_{3}[\mathrm{M}+\mathrm{H}]^{+}$263.1139; found 263.1134.

Ethyl (1-(5-phenyl-1H-tetrazol-1-yl)ethyl) carbonate (Table 1, 2b)

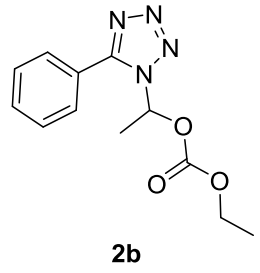

$\mathrm{R}_{f}=0.13$ (heptane/EtOAc 4:1 (v/v). m.p. $71.5-72.5^{\circ} \mathrm{C}$ (heptane). NMR Spectroscopy: ${ }^{1} \mathrm{H}$ NMR 
(600 MHz, $\left.\mathrm{CDCl}_{3}, 25{ }^{\circ} \mathrm{C}, \delta\right): 7.73-7.69(\mathrm{~m}, 2 \mathrm{H}), 7.65-7.57(\mathrm{~m}, 3 \mathrm{H}), 6.85$ (q, $\left.J=6.5 \mathrm{~Hz}, 1 \mathrm{H}\right)$, $4.23-4.14(\mathrm{~m}, 2 \mathrm{H}), 1.98(\mathrm{~d}, J=6.5 \mathrm{~Hz}, 2 \mathrm{H}), 1.29$ (t, $J=7.0 \mathrm{~Hz}, 3 \mathrm{H}) .{ }^{13} \mathrm{C}$ NMR $\left(151 \mathrm{MHz}, \mathrm{CDCl}_{3}\right.$, $25{ }^{\circ} \mathrm{C}, \delta$ ): $154.5,152.9,131.5,129.2$ 129.1, 123.6, 79.6, 65.2, 20.2, 14.0. IR (thin film, $\mathrm{cm}^{-1}$ ): 1753, 1246, 1091, 697. HRMS (m/z): calculated for $\mathrm{C}_{12} \mathrm{H}_{14} \mathrm{~N}_{4} \mathrm{O}_{3}[\mathrm{M}+\mathrm{H}]^{+}$263.1139; found 263.1135 .

An X-ray crystal structure of $\mathbf{2 b}$ was obtained (see X-ray results, Figure S5, and Table S3 below).

\section{Experimental procedures for synthesis of 2,5-disubstituted tetrazoles (Table 1)}

\section{Ethyl (1-(5-phenyl-2H-tetrazol-2-yl)ethyl) carbonate (Table 1, 2a)}

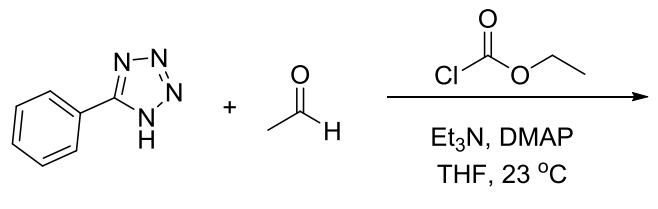

$98 \%$

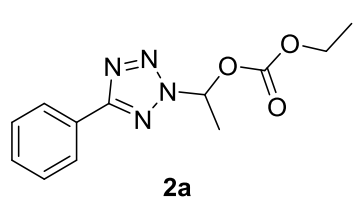

$2 \mathbf{a}$

A round-bottom flask was charged with 5-phenyl- $1 H$-tetrazole (107 mg, $0.735 \mathrm{mmol}, 1.00$ equiv), 4-dimethylaminopyridine (5.6 mg, $46 \mu \mathrm{mol}, 6 \mathrm{~mol} \%)$, THF $(2 \mathrm{~mL})$, acetaldehyde $(50.5 \mu \mathrm{L}, 0.808$ mmol, 1.10 equiv), triethylamine (113 $\mu \mathrm{L}, 0.808 \mathrm{mmol}, 1.10$ equiv), and lastly ethyl chloroformate $(73.8 \mu \mathrm{L}, 0.772 \mathrm{mmol}, 1.05$ equiv). The reaction mixture was stirred overnight at room temperature. The reaction mixture was then diluted with $\mathrm{Et}_{2} \mathrm{O}$ and filtered through a plug of Celite twice. The reaction mixture was concentrated in vacuo to afford $190 \mathrm{mg}$ ( $98 \%$ yield) of the title compound (2a) as a colorless oil.

See above for full characterization.

\section{1-(5-Phenyl-2H-tetrazol-2-yl)ethyl pivalate (Table 1, 3)}

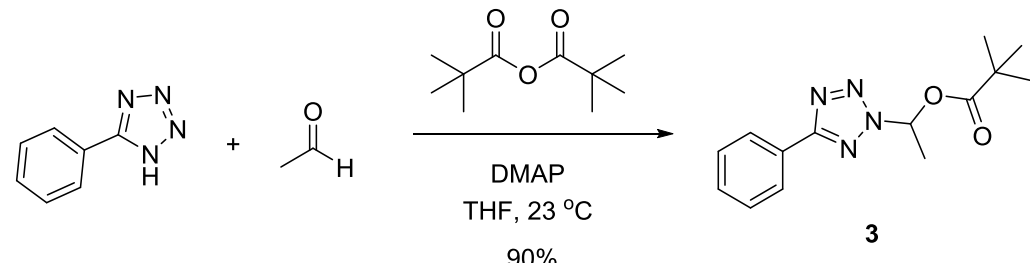

A round-bottom flask was charged with 5-phenyl- $1 H$-tetrazole (106 mg, $0.727 \mathrm{mmol}, 1.00$ equiv), THF $(2 \mathrm{~mL})$ acetaldehyde $(50.0 \mu \mathrm{L}, 0.800 \mathrm{mmol}, 1.10$ equiv), pivalic anhydride (162 $\mu \mathrm{L}, 0.800$ mmol, 1.10 equiv) and 4-dimethylaminopyridine $(6.6 \mathrm{mg}, 74 \mu \mathrm{mol}, 5 \mathrm{~mol} \%)$. The reaction mixture was stirred for $9 \mathrm{~d}$ at room temperature. The reaction mixture was then diluted with EtOAc and $\mathrm{H}_{2} \mathrm{O}$ and transferred to a separatory funnel. The layers were separated. The aqueous layer was extracted with EtOAc. The combined organic layers were dried over $\mathrm{MgSO}_{4}$, filtered, and concentrated in vacuo. The residue was diluted with heptane and filtered through a plug of 
Celite and concentrated in vacuo to afford $179 \mathrm{mg}$ (90\% yield) of the title compound (3) as a colorless solid.

$\mathrm{R}_{f}=0.51$ (heptane/EtOAc 4:1 (v/v). m.p. 61.3-62.0 ${ }^{\circ} \mathrm{C}$ (heptane). NMR Spectroscopy: ${ }^{1} \mathrm{H}$ NMR (600 MHz, $\mathrm{CDCl}_{3}, 25^{\circ} \mathrm{C}, \delta$ ): 8.21-8.17 (m, 2H), 7.53-7.47 (m, 3H), 7.34 (q, J=6.5 Hz, 1H), 2.02 (d, $J=6.5 \mathrm{~Hz}, 3 \mathrm{H}), 1.22$ (s, 9H). ${ }^{13} \mathrm{C}$ NMR (151 MHz, $\left.\mathrm{CDCl}_{3}, 25{ }^{\circ} \mathrm{C}, \delta\right): 176.2,165.1,130.5$, 128.9, 127.1, 127.0, 80.1, 38.7 26.7, 19.2. IR (thin film, $\mathrm{cm}^{-1}$ ): 1749, 1468, 1450, 1129, 1085 , 733, 694. HRMS (m/z): calculated for $\mathrm{C}_{14} \mathrm{H}_{18} \mathrm{~N}_{4} \mathrm{NaO}_{2}[\mathrm{M}+\mathrm{Na}]^{+}$297.1322; found 297.1320.

\section{Ethyl (2-methyl-1-(5-phenyl-2H-tetrazol-2-yl)propyl) carbonate (Table 1, 4)}

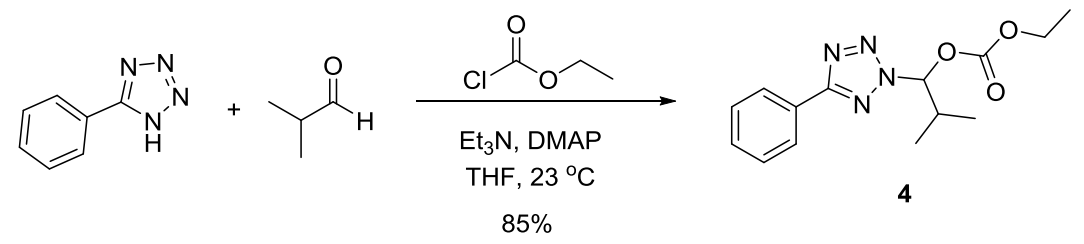

A round-bottom flask was charged with 5-phenyl- $1 H$-tetrazole (104 mg, $0.708 \mathrm{mmol}, 1.00$ equiv), 4-dimethylaminopyridine ( $4.2 \mathrm{mg}, 34 \mu \mathrm{mol}, 5 \mathrm{~mol} \%)$, THF $(2 \mathrm{~mL})$, isobutyraldehyde $(64.4 \mu \mathrm{L}$, $0.708 \mathrm{mmol}, 1.00$ equiv), triethylamine (113 $\mu \mathrm{L}, 0.810 \mathrm{mmol}, 1.14$ equiv), and lastly ethyl chloroformate $(71.0 \mu \mathrm{L}, 0.743 \mathrm{mmol}, 1.05$ equiv). The reaction mixture was stirred for $36 \mathrm{~h}$ at room temperature. The reaction mixture was then diluted with EtOAc and $\mathrm{H}_{2} \mathrm{O}$ and transferred to a separatory funnel. The layers were separated. The aqueous layer was extracted with EtOAc. The combined organic layers were dried over $\mathrm{MgSO}_{4}$, filtered, and concentrated in vacuo to afford $174 \mathrm{mg}$ (85\% yield) of the title compound (4) as a colorless oil.

$\mathrm{R}_{f}=0.44$ (heptane/EtOAc 4:1 (v/v). NMR Spectroscopy: ${ }^{1} \mathrm{H}$ NMR $\left(600 \mathrm{MHz}, \mathrm{CDCl}_{3}, 25{ }^{\circ} \mathrm{C}, \delta\right)$ : 8.22-8.17 (m, 2H), 7.53-7.47 (m, 3H), 6.78 (d, $J=8.8 \mathrm{~Hz}, 1 \mathrm{H}), 4.30-4.20$ (m, 2H), 2.85-2.77 (m, $1 \mathrm{H}), 1.32$ (t, $J=7.1 \mathrm{~Hz}, 3 \mathrm{H}), 1.19$ (d, $J=6.7 \mathrm{~Hz}, 3 \mathrm{H}), 0.89$ (d, $J=6.7 \mathrm{~Hz}, 3 \mathrm{H}) .{ }^{13} \mathrm{C}$ NMR $(151$ $\left.\mathrm{MHz}, \mathrm{CDCl}_{3}, 25^{\circ} \mathrm{C}, \delta\right): 165.3,153.4,130.5,128.8,127.1,90.4,65.3,32.3,17.6,17.3,14.0$. IR (thin film, $\mathrm{cm}^{-1}$ ): 1760, 1468, 1450, 1249, 1009, 733, 694. HRMS (m/z): calculated for $\mathrm{C}_{14} \mathrm{H}_{18} \mathrm{~N}_{4} \mathrm{NaO}_{3}[\mathrm{M}+\mathrm{Na}]^{+}$313.1271; found 313.1269.

Methyl 2-(1-((ethoxycarbonyl)oxy)ethyl)-2H-tetrazole-5-carboxylate (Table 1, 5)

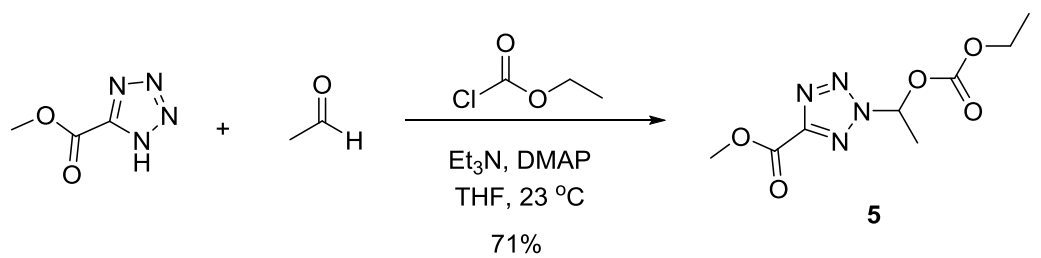

A round-bottom flask was charged with methyl $1 H$-tetrazole-5-carboxylate $(74.0 \mathrm{mg}, 0.578$ mmol, 1.00 equiv), THF ( $2 \mathrm{~mL})$, 4-dimethylaminopyridine (4.1 mg, $34 \mu \mathrm{mol}, 6 \mathrm{~mol} \%$ ), acetaldehyde $(39.7 \mu \mathrm{L}, 0.708 \mathrm{mmol}, 1.00$ equiv), triethylamine $(88.6 \mu \mathrm{L}, 0.636 \mathrm{mmol}, 1.10$ 
equiv), and lastly ethyl chloroformate $(58.0 \mu \mathrm{L}, 0.607 \mathrm{mmol}, 1.05$ equiv). The reaction mixture was stirred for $16 \mathrm{~h}$ at room temperature. The reaction mixture was then diluted with EtOAc and $\mathrm{H}_{2} \mathrm{O}$ and transferred to a separatory funnel. The layers were separated. The aqueous layer was extracted with EtOAc. The combined organic layers were dried over $\mathrm{MgSO}_{4}$, filtered, and concentrated in vacuo to afford $99.7 \mathrm{mg}$ (71\% yield) of the title compound (5) as a colorless oil.

$\mathrm{R}_{f}=0.14$ (heptane/EtOAc 4:1 (v/v). NMR Spectroscopy: ${ }^{1} \mathrm{H}$ NMR (600 MHz, $\left.\mathrm{CDCl}_{3}, 25{ }^{\circ} \mathrm{C}, \delta\right)$ : 7.25 (q, $J=6.5 \mathrm{~Hz}, 1 \mathrm{H}), 4.30-4.22(\mathrm{~m}, 2 \mathrm{H}), 4.07$ (s, 3H), 2.06 (d, J=6.3 Hz, 3H), 1.32 (t, $J=7.0$ $\mathrm{Hz}, 3 \mathrm{H}) .{ }^{13} \mathrm{C} \mathrm{NMR}\left(151 \mathrm{MHz}, \mathrm{CDCl}_{3}, 25^{\circ} \mathrm{C}, \delta\right): 157.9,157.6,152.7,83.7,65.5,53.2,19.4,14.0$. IR (thin film, $\mathrm{cm}^{-1}$ ): 1751, 1254, 1231, 1060. HRMS (m/z): calculated for $\mathrm{C}_{8} \mathrm{H}_{12} \mathrm{~N}_{4} \mathrm{NaO}_{5}[\mathrm{M}+$ $\mathrm{Na}]^{+}$267.0700; found 267.0696.

\section{1-(5-(tert-Butyl)-2H-tetrazol-2-yl)ethyl ethyl carbonate (Table 1, 6)}
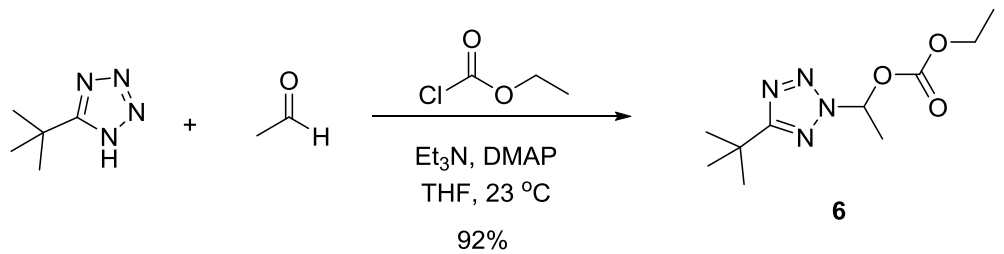

A round-bottom flask was charged with 5-(tert-butyl)- $1 H$-tetrazole $(93.5 \mathrm{mg}, 0.741 \mathrm{mmol}, 1.00$ equiv), THF ( $2 \mathrm{~mL})$, 4-dimethylaminopyridine $(6.0 \mathrm{mg}, 49 \mu \mathrm{mol}, 7 \mathrm{~mol} \%)$, acetaldehyde (50.9 $\mu \mathrm{L}, 0.815 \mathrm{mmol}, 1.10$ equiv), triethylamine (114 $\mu \mathrm{L}, 0.815 \mathrm{mmol}, 1.10$ equiv), and lastly ethyl chloroformate $(74.4 \mu \mathrm{L}, 0.778 \mathrm{mmol}, 1.05$ equiv). The reaction mixture was stirred for $16 \mathrm{~h}$ at room temperature. The reaction mixture was then diluted with EtOAc and $\mathrm{H}_{2} \mathrm{O}$ and transferred to a separatory funnel. The layers were separated. The aqueous layer was extracted with EtOAc. The combined organic layers were dried over $\mathrm{MgSO}_{4}$, filtered, and concentrated in vacuo to afford $165 \mathrm{mg}$ (92\% yield) of the title compound (6) as a colorless oil.

$\mathrm{R}_{f}=0.43$ (heptane/EtOAc 4:1 (v/v). NMR Spectroscopy: ${ }^{1} \mathrm{H}$ NMR (600 MHz, $\left.\mathrm{CDCl}_{3}, 25{ }^{\circ} \mathrm{C}, \delta\right)$ : 7.15 (q, $J=6.5 \mathrm{~Hz}, 1 \mathrm{H}), 4.30-4.22(\mathrm{~m}, 1 \mathrm{H}), 2.00$ (d, $J=6.5 \mathrm{~Hz}, 3 \mathrm{H}), 1.44$ (s, 9H), 1.33 (t, $J=7.0$ $\mathrm{Hz}, 3 \mathrm{H}) .{ }^{13} \mathrm{C} \mathrm{NMR}\left(151 \mathrm{MHz}, \mathrm{CDCl}_{3}, 25{ }^{\circ} \mathrm{C}, \delta\right): 174.7,153.0,82.7,65.1,31.6,29.4,19.2$, 14.0. IR (thin film, $\mathrm{cm}^{-1}$ ): 2972, 1760, 1255. HRMS (m/z): calculated for $\mathrm{C}_{10} \mathrm{H}_{18} \mathrm{~N}_{4} \mathrm{NaO}_{3}\left[\mathrm{M}+\mathrm{Na}^{+}\right.$ 265.1271 ; found 265.1267 .

Ethyl (1-(5-(4-iodo-1-methyl-1H-pyrazol-5-yl)-2H-tetrazol-2-yl)ethyl) carbonate (Table 1, 7)
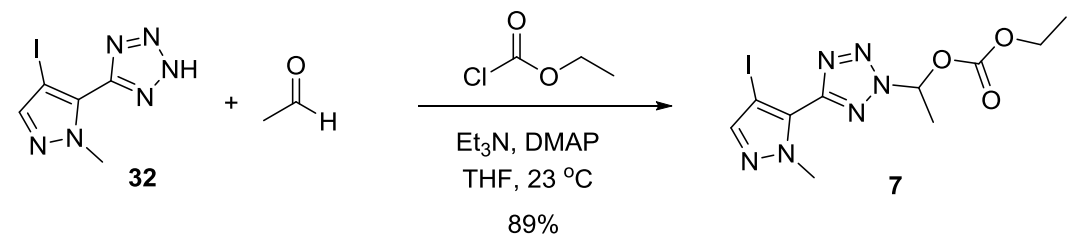

A round bottom flask was charged with 5-(4-iodo-1-methyl- $1 H$-pyrazol-5-yl)-2H-tetrazole (32), ${ }^{2}$ 
(50.0 g, $181 \mathrm{mmol}, 1.00$ equiv), 4-dimethylaminopyridine (1.14 g, $9.33 \mathrm{mmol}, 5.2 \mathrm{~mol} \%$ ), acetaldehyde (12.6 mL, $202 \mathrm{mmol}, 1.11$ equiv), triethylamine (27.8 mL, $0.199 \mathrm{mmol}, 1.10$ equiv), THF $(450 \mathrm{~mL})$. The reaction mixture was cooled to $0{ }^{\circ} \mathrm{C}$. Ethyl chloroformate $(17.4 \mathrm{~mL}, 181$ mmol, 1.00 equiv) was added and the reaction mixture was allowed to warm to room temperature and stirred for $72 \mathrm{~h}$. The reaction mixture was then diluted with $\mathrm{H}_{2} \mathrm{O}(100 \mathrm{~mL})$ and transferred to a separatory funnel. The layers were separated. The organic layer was washed with brine (100 $\mathrm{mL})$. The combined aqueous layers were extracted with EtOAc $(2 \times 100 \mathrm{~mL})$. The combined organic layers were dried over $\mathrm{MgSO}_{4}$, filtered, and concentrated in vacuo. The residue was diluted with EtOAc and filtered through a plug of Celite and concentrated in vacuo to afford 63.5 $\mathrm{g}(89 \%$ yield) of the title compound (7).

$\mathrm{R}_{f}=0.18$ (heptane/EtOAc 4:1 (v/v)). NMR Spectroscopy: ${ }^{1} \mathrm{H}$ NMR (400 MHz, $\left.\mathrm{CDCl}_{3}, 25^{\circ} \mathrm{C}, \delta\right)$ : 7.62 (s, 1H), 7.27 (q, J=5.9 Hz, 1H), 4.29-4.23 (m, 2H), 4.22 (s, 3H), 2.09 (d, J=5.9 Hz, 3H), 1.32 (t, $J=7.3 \mathrm{~Hz}, 3 \mathrm{H}) .{ }^{13} \mathrm{C} \mathrm{NMR}\left(101 \mathrm{MHz}, \mathrm{CDCl}_{3}, 25{ }^{\circ} \mathrm{C}, \delta\right): 156.9,153.0,145.3,131.4,83.4$, 65.5, 60.9, 40.4, 19.4, 14.2. IR (thin film, $\mathrm{cm}^{-1}$ ): 1758, 1371, 1249, 1116, 1016, 993, 957, 859, 785. HRMS (m/z): calculated for $\mathrm{C}_{10} \mathrm{H}_{14} \mathrm{IN}_{6} \mathrm{O}_{3}[\mathrm{M}+\mathrm{H}]^{+}$393.0167; found 393.0166.

\section{1-(5-Phenyl-2H-tetrazol-2-yl)cyclobutyl isobutyrate (Table 1, 8)}

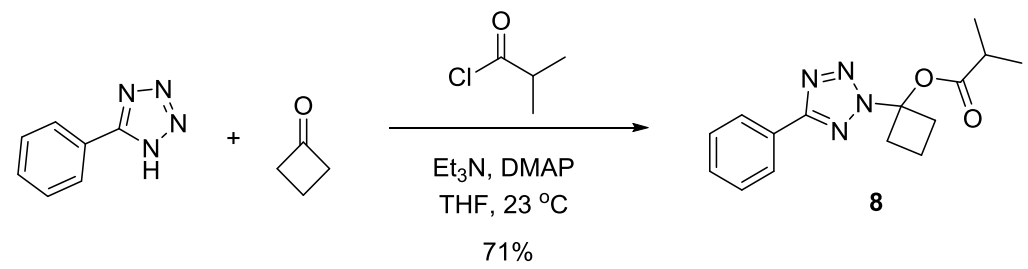

A round-bottom flask was charged with 5-phenyl-1H-tetrazole (335 mg, $2.29 \mathrm{mmol}, 1.00$ equiv), 4-dimethylaminopyridine (28.1 mg, $0.229 \mathrm{mmol}, 10 \mathrm{~mol} \%)$, THF (23 mL), cyclobutanone (343 $\mu \mathrm{L}, 4.58 \mathrm{mmol}, 2.00$ equiv), triethylamine ( $379 \mu \mathrm{L}, 2.75 \mathrm{mmol}, 1.20$ equiv), and lastly isobutyryl chloride ( $288 \mu \mathrm{L}, 2.75 \mathrm{mmol}, 1.20$ equiv). The reaction mixture was stirred for $72 \mathrm{~h}$ at room temperature at which point additional cyclobutanone ( $343 \mu \mathrm{L}, 4.58 \mathrm{mmol}, 2.00$ equiv) was added. The reaction mixture was stirred at room temperature for $48 \mathrm{~h}$. The reaction mixture was then diluted with EtOAc and washed with $\mathrm{H}_{2} \mathrm{O}$ and brine. The organic layers was dried over $\mathrm{Na}_{2} \mathrm{SO}_{4}$, filtered, and concentrated in vacuo. The residue was purified by silica gel chromatography (gradient of $0-30 \%$ EtOAc in heptane (v/v)) to afford $466 \mathrm{mg}$ (71\% yield) of the title compound (8).

$\mathrm{R}_{f}=0.41$ (heptane/EtOAc 9:1 (v/v)). NMR Spectroscopy: ${ }^{1} \mathrm{H}$ NMR $\left(400 \mathrm{MHz}, \mathrm{CDCl}_{3}, 25^{\circ} \mathrm{C}, \delta\right)$ : 8.19-8.17 (m, 2H), 7.52-7.46 (m, 3H), 3.31-3.24 (m, 2H), 2.97-2.88 (m, 2H), 2.63 (septet, $J=7.0$ $\mathrm{Hz}, 1 \mathrm{H}), 2.16-2.04(\mathrm{~m}, 2 \mathrm{H}), 1.18(\mathrm{~d}, J=7.0 \mathrm{~Hz}, 6 \mathrm{H}) .{ }^{13} \mathrm{C} \mathrm{NMR}\left(101 \mathrm{MHz}, \mathrm{CDCl}_{3}, 25{ }^{\circ} \mathrm{C}, \delta\right)$ : $174.7,165.2,130.5,129.0,127.5,127.1,92.1,35.1,34.1,18.6,13.8$. IR (thin film, $\mathrm{cm}^{-1}$ ): 1758, 1467, 1451, 1130, 1022, 733, 695. HRMS (m/z): calculated for $\mathrm{C}_{15} \mathrm{H}_{19} \mathrm{~N}_{4} \mathrm{O}_{2}[\mathrm{M}+\mathrm{H}]^{+}$287.1503; found 287.1502 . 


\section{(4-bromophenyl)(5-phenyl-2H-tetrazol-2-yl)methyl isobutyrate (Table 1, 9)}

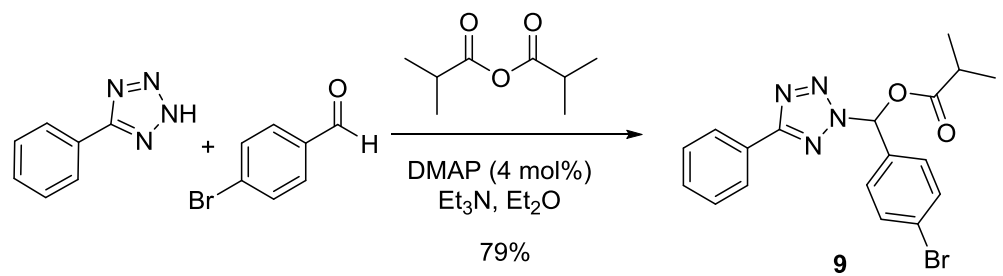

A vial was charged with 5-phenyl- $1 H$-tetrazole $(25.0 \mathrm{mg}, 0.171 \mathrm{mmol}, 1.00$ equiv), 4dimethylaminopyridine (3.3 mg, $6.8 \mu \mathrm{mol}, 4 \mathrm{~mol} \%), \mathrm{Et}_{2} \mathrm{O}(2 \mathrm{~mL}), 4$-bromobenzaldehyde (139 $\mathrm{mg}, 0.188 \mathrm{mmol}, 1.10$ equiv), triethylamine (105 $\mu \mathrm{L}, 0.188 \mathrm{mmol}, 1.10$ equiv), and lastly isobutyric anhydride (147 $\mu \mathrm{L}, 0.222 \mathrm{mmol}, 1.30$ equiv). The reaction mixture was stirred overnight at room temperature. The reaction mixture was concentrated in vacuo. The residue was purified by silica gel chromatography (gradient of 0-20\% EtOAc in heptane (v/v)) to afford $54 \mathrm{mg}$ (79\% yield) of the title compound (9).

$\mathrm{R}_{f}=0.30$ (heptane/EtOAc 9:1 (v/v)). NMR Spectroscopy: ${ }^{1} \mathrm{H}$ NMR $\left(400 \mathrm{MHz}, \mathrm{CDCl}_{3}, 25^{\circ} \mathrm{C}, \delta\right)$ : 8.17-8.10 (m, 3H), 7.63-7.56 (m, 2H), 7.54-7.50 (m, 2H), 7.49-7.43 (m, 3H), 2.75 (qq, J=7.0, $7.0 \mathrm{~Hz}, 1 \mathrm{H}), 1.25(\mathrm{~d}, J=6.8 \mathrm{~Hz}, 3 \mathrm{H}), 1.23(\mathrm{~d}, J=6.8 \mathrm{~Hz}, 3 \mathrm{H}) .{ }^{13} \mathrm{C} \mathrm{NMR}\left(101 \mathrm{MHz}, \mathrm{CDCl}_{3}, 25{ }^{\circ} \mathrm{C}\right.$,

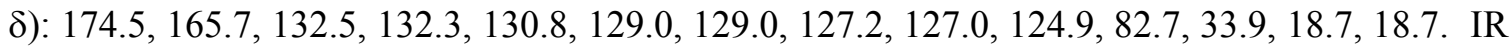
(thin film, $\mathrm{cm}^{-1}$ ): 1761, 1468, 1450, 1094, 1072, 1014. HRMS (m/z): calculated for $\mathrm{C}_{18} \mathrm{H}_{17} \mathrm{BrN}_{4} \mathrm{NaO}_{2}[\mathrm{M}+\mathrm{Na}]^{+}$423.0427; found 423.0422.

1-(5-Phenyl-2H-tetrazol-2-yl)ethyl 4-methylbenzenesulfonate (Table 1, 10)

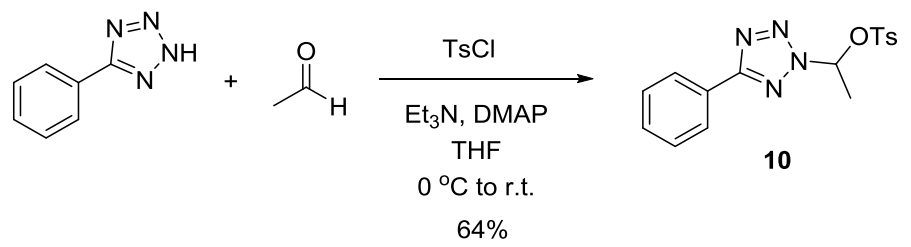

A round-bottom flask was charged with 5-phenyl- $1 H$-tetrazole $(0.500 \mathrm{~g}, 3.42 \mathrm{mmol}, 1.00$ equiv), THF $(9.3 \mathrm{~mL})$, and acetaldehyde $(0.851 \mathrm{~mL}, 16.3 \mathrm{mmol}, 4.77$ equiv). The solution was stirred for $5 \mathrm{~min}$ at room temperature and then DMAP (16.7 $\mathrm{mg}, 0.137 \mathrm{mmol}, 4.0 \mathrm{~mol} \%)$ was added followed by triethylamine $\left(0.500 \mathrm{~mL}, 3.58 \mathrm{mmol}, 1.05\right.$ equiv). The reaction was cooled to $0{ }^{\circ} \mathrm{C}$, and $p$-toluenesulfonyl chloride (621 mg, $3.26 \mathrm{mmol}, 0.953$ equiv) dissolved in THF (1.5 mL) was added dropwise over $30 \mathrm{~min}$. The reaction was maintained at $0{ }^{\circ} \mathrm{C}$ for $1 \mathrm{~h}$, and then warmed to room temperature and stirred for $16 \mathrm{~h}$ at room temperature. The reaction mixture was concentrated in vacuo, and the residue was purified by silica gel chromatography (gradient of 0 $25 \%$ EtOAc in heptane $(\mathrm{v} / \mathrm{v}))$ to afford $751 \mathrm{mg}(64 \%$ yield) of the title compound (10).

$\mathrm{R}_{f}=0.33$ (heptane/EtOAc 4:1 (v/v)). NMR Spectroscopy: ${ }^{1} \mathrm{H}$ NMR (400 MHz, $\left.\mathrm{CDCl}_{3}, 25{ }^{\circ} \mathrm{C}, \delta\right)$ : 7.96-7.94 (m, 2H), 7.57 (d, $J=8.0 \mathrm{~Hz}, 2 \mathrm{H}), 7.48-7.44$ (m, 3H), 7.08 (d, J=8.0 Hz, 2H), 7.00 (q, 
$J=6.2 \mathrm{~Hz}, 1 \mathrm{H}), 2.12(\mathrm{~s}, 3 \mathrm{H}), 2.08(\mathrm{~d}, J=6.2 \mathrm{~Hz}, 3 \mathrm{H}) .{ }^{13} \mathrm{C} \mathrm{NMR}\left(101 \mathrm{MHz}, \mathrm{CDCl}_{3}, 25{ }^{\circ} \mathrm{C}, \delta\right)$ : 165.3, 145.6, 132.8, 130.8, 129.7, 129.0, 127.9, 127.1, 126.7, 85.4, 21.4, 20.7. IR (thin film, $\mathrm{cm}^{-}$ $\left.{ }^{1}\right)$ : $1597,1531,1469,1450,1373,1190,1177,1118,1071,1018$. HRMS (m/z): calculated for $\mathrm{C}_{16} \mathrm{H}_{17} \mathrm{~N}_{4} \mathrm{O}_{3} \mathrm{~S}[\mathrm{M}+\mathrm{H}]^{+}$345.1016; found 345.1016.

\section{1-(5-Phenyl-2H-tetrazol-2-yl)ethyl methanesulfonate (S-1)}

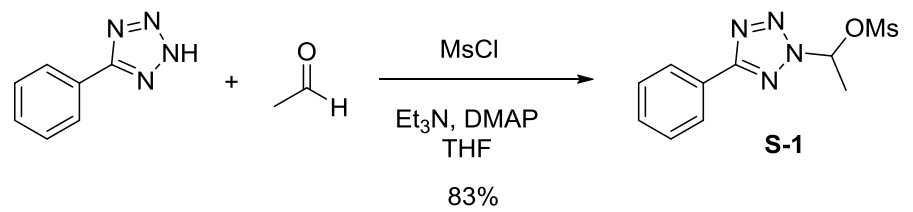

A round-bottom flask was charged with 5-phenyl- $1 H$-tetrazole $(1.00 \mathrm{~g}, 6.84 \mathrm{mmol}, 1.00$ equiv), THF (23 mL) and acetaldehyde ( $1.5 \mathrm{~mL}, 5.0 \mathrm{M}$ solution in THF, $7.5 \mathrm{mmol}$. 1.1 equiv). The solution was stirred for $5 \mathrm{~min}$ at room temperature and then DMAP (35.0 $\mathrm{mg}, 0.286 \mathrm{mmol}, 4.2$ mol\%) was added followed by triethylamine ( $1.05 \mathrm{~mL}, 7.53 \mathrm{mmol}, 1.10$ equiv). Methanesulfonyl chloride $(0.530 \mathrm{~mL}, 0.684 \mathrm{mmol}, 1.00$ equiv) was added dropwise at room temperature. The reaction was stirred for $16 \mathrm{~h}$ at room temperature. The reaction was quenched via the addition of $\mathrm{H}_{2} \mathrm{O}(30 \mathrm{~mL})$, and extracted with EtOAc $(3 \times 25 \mathrm{~mL})$. The combined organic extracts were dried over $\mathrm{Na}_{2} \mathrm{SO}_{4}$, filtered, and concentrated in vacuo. The residue was redissolved in EtOAc (25 $\mathrm{mL}$ ), filtered through a plug of silica, and concentrated in vacuo to afford $1.53 \mathrm{~g}$ (83\% yield) of the title compound (S-1).

$\mathrm{R}_{f}=0.38$ (heptane/EtOAc 3:1 (v/v)). m.p. 88.3-88.7 ${ }^{\circ} \mathrm{C}$ (heptane). NMR Spectroscopy: ${ }^{1} \mathrm{H}$ NMR (400 MHz, $\mathrm{CDCl}_{3}, 25^{\circ} \mathrm{C}, \delta$ ): 8.20-8.16 (m, 2H), 7.52-7.50 (m, 3H), 7.09 (q, J=6.2 Hz, 1H), 2.99 (s, 3H), 2.18 (d, J=6.2 Hz, 3H). ${ }^{13} \mathrm{C}$ NMR (101 MHz, $\left.\mathrm{CDCl}_{3}, 25{ }^{\circ} \mathrm{C}, \delta\right): 165.8,131.0,129.1$, 127.1, 126.5, 85.0, 39.3, 20.3. IR (thin film, $\mathrm{cm}^{-1}$ ): 2986, 1465, 1450, 1333, 1072, 1040, 1027. HRMS (m/z): calculated for $\mathrm{C}_{10} \mathrm{H}_{12} \mathrm{~N}_{4} \mathrm{O}_{3} \mathrm{~S}[\mathrm{M}+\mathrm{H}]^{+}$269.0703; found 269.0699.

\section{Elaboration of sulfonate ester products (Table 2)}

\section{2-Ethyl-5-phenyl-2H-tetrazole (Table 2, 11)}

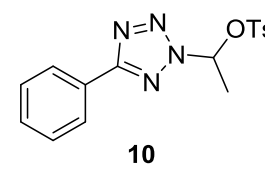

10

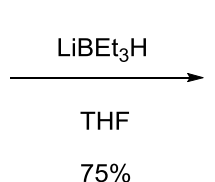

$75 \%$

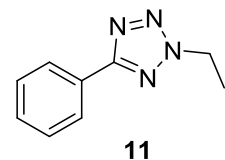

11

An oven-dried microwave vial was charged with 1-(5-phenyl-2H-tetrazol-2-yl)ethyl 4methylbenzenesulfonate (10) $(0.100 \mathrm{~g}, 0.290 \mathrm{mmol}, 1.00$ equiv). The atmosphere was exchanged for nitrogen. THF $(0.97 \mathrm{~mL})$ was added followed by lithium triethylborohydride $(0.87 \mathrm{~mL}, 0.87$ mmol, 1.0 M in THF, 3.0 equiv). The reaction mixture was stirred at room temperature for $4 \mathrm{~h}$. The reaction mixture was quenched via the addition of $\mathrm{H}_{2} \mathrm{O}(6 \mathrm{~mL})$, extracted with EtOAc $(3 \times 5$ 
$\mathrm{mL}$ ). The combined organic layers were dried over $\mathrm{Na}_{2} \mathrm{SO}_{4}$, filtered, and concentrated in vacuo. The residue was redissolved in EtOAc, filtered through a plug of silica, and concentrated in vacuo to afford $37.5 \mathrm{mg}$ (75\% yield) of the title compound (11).

NMR Spectroscopy: ${ }^{1} \mathrm{H}$ NMR (400 MHz, $\left.\mathrm{CDCl}_{3}, 25{ }^{\circ} \mathrm{C}, \delta\right): 8.17-8.14(\mathrm{~m}, 2 \mathrm{H}), 7.52-7.44(\mathrm{~m}$, $3 \mathrm{H}), 4.69$ (q, $J=7.4 \mathrm{~Hz}, 2 \mathrm{H}), 1.68$ (t, $J=7.4 \mathrm{~Hz}, 3 \mathrm{H}) .{ }^{13} \mathrm{C} \mathrm{NMR}\left(101 \mathrm{MHz}, \mathrm{CDCl}_{3}, 25{ }^{\circ} \mathrm{C}, \delta\right)$ : $165.2,130.3,129.0,127.7,126.9,48.5,14.7$. IR (thin film, $\mathrm{cm}^{-1}$ ): 1528, 1464, 1449, 1380, 1348, 1189, 1189, 1071, 1044, 1027, 1007. HRMS (m/z): calculated for $\mathrm{C}_{9} \mathrm{H}_{11} \mathrm{~N}_{4}[\mathrm{M}+\mathrm{H}]^{+} 175.0978$; found 175.0975 .

\section{2-Isopropyl-5-phenyl-2H-tetrazole (Table 2, 12)}

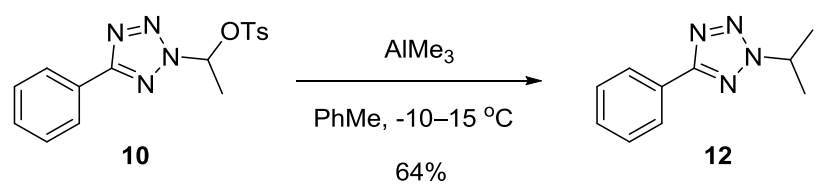

An oven-dried microwave vial was charged with 1-(5-phenyl-2H-tetrazol-2-yl)ethyl 4methylbenzenesulfonate (10) $(74.0 \mathrm{mg}, 0.215 \mathrm{mmol}, 1.0$ equiv). The atmosphere was exchanged for nitrogen. PhMe $(2.2 \mathrm{~mL})$ was added and the reaction mixture was cooled to $-10{ }^{\circ} \mathrm{C}$. Trimethyl aluminum $(0.27 \mathrm{~mL}, 0.54 \mathrm{mmol}, 2.0 \mathrm{M}$ in PhMe, 2.5 equiv) was added dropwise at -10 ${ }^{\circ} \mathrm{C}$. The reaction mixture was stirred at $-10{ }^{\circ} \mathrm{C}$ for $1 \mathrm{~h}$, warmed to $15^{\circ} \mathrm{C}$, and stirred for $1 \mathrm{~h}$. The reaction mixture was cooled back to $-10{ }^{\circ} \mathrm{C}$ and quenched via dropwise addition of $1 \mathrm{M} \mathrm{HCl}$ (2 $\mathrm{mL})$. The reaction mixture was extracted with EtOAc $(3 \times 5 \mathrm{~mL})$. The combined organic layers were dried over $\mathrm{Na}_{2} \mathrm{SO}_{4}$, filtered, and concentrated in vacuo. The residue was purified by silica gel chromatography (gradient of $0-20 \%$ EtOAc in heptane (v/v)) to afford $26 \mathrm{mg}$ (64\% yield) of the title compound (12). ${ }^{3}$

NMR Spectroscopy: ${ }^{1} \mathrm{H}$ NMR (400 MHz, $\left.\mathrm{CDCl}_{3}, 25^{\circ} \mathrm{C}, \delta\right): 8.18-8.14(\mathrm{~m}, 2 \mathrm{H}), 7.52-7.44(\mathrm{~m}$, $3 \mathrm{H}), 5.11$ (septet, $J=6.8 \mathrm{~Hz}, 1 \mathrm{H}), 1.71(\mathrm{~d}, J=6.6 \mathrm{~Hz}, 6 \mathrm{H}) .{ }^{13} \mathrm{C} \mathrm{NMR}\left(101 \mathrm{MHz}, \mathrm{CDCl}_{3}, 25{ }^{\circ} \mathrm{C}, \delta\right)$ : $164.9,130.3,129.0,127.9,127.0,56.7,22.4$. IR (thin film, $\mathrm{cm}^{-1}$ ): 1528, 1465, 1450, 1371, 1333, 1188, 1072, 1040, 1027. HRMS (m/z): calculated for $\mathrm{C}_{10} \mathrm{H}_{13} \mathrm{~N}_{4}[\mathrm{M}+\mathrm{H}]^{+}$189.1135; found 186.1133.

\section{2-(1-Fluoroethyl)-5-phenyl-2H-tetrazole (Table 2, 13)}

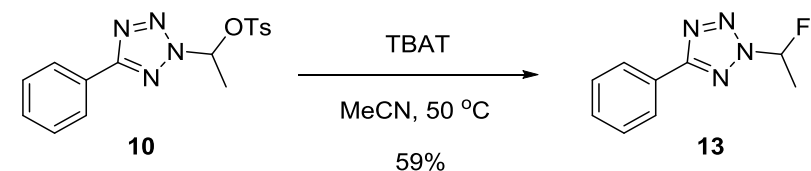

An oven-dried microwave vial was charged with 1-(5-Phenyl-2H-tetrazol-2-yl)ethyl 4methylbenzenesulfonate (10) $(0.100 \mathrm{~g}, 0.290 \mathrm{mmol}, 1.00$ equiv). The atmosphere was exchanged for nitrogen. MeCN (1.5 mL) was added followed by added tetrabutylammonium 
difluorotriphenylsilicate (TBAT) $(470 \mathrm{mg}, 0.870 \mathrm{mmol}, 3.00$ equiv). The reaction mixture was heated at $50{ }^{\circ} \mathrm{C}$ for $48 \mathrm{~h}$. The reaction mixture was cooled to room temperature and filtered. The filter cake washed with $\mathrm{MeCN}(10 \mathrm{~mL})$ and the combined organic filtrates were concentrated in vacuo. The residue was purified by silica gel chromatography (gradient of 0-40\% EtOAc in heptane $(\mathrm{v} / \mathrm{v}))$ to afford $32.9 \mathrm{mg}(59 \%$ yield) of the title compound (13) as a colorless oil.

NMR Spectroscopy: ${ }^{1} \mathrm{H}$ NMR (400 MHz, $\left.\mathrm{CDCl}_{3}, 25{ }^{\circ} \mathrm{C}, \delta\right): 8.23-8.19(\mathrm{~m}, 2 \mathrm{H}), 7.54-7.50$ (m, $3 \mathrm{H}), 6.86(\mathrm{dq}, J=51 \mathrm{~Hz}, 7.5 \mathrm{~Hz}, 1 \mathrm{H}), 2.16(\mathrm{dd}, J=24 \mathrm{~Hz}, 7.5 \mathrm{~Hz}, 3 \mathrm{H}) .{ }^{13} \mathrm{C}$ NMR $(101 \mathrm{MHz}$, $\mathrm{CDCl}_{3}, 25^{\circ} \mathrm{C}, \delta$ ): $165.8,130.9,129.1,127.3,127.0,95.2$ (d, $\left.J=211 \mathrm{~Hz}\right), 19.2$ (d, $\left.J=25 \mathrm{~Hz}\right)$. IR (thin film, $\mathrm{cm}^{-1}$ ): 1531, 1470, 1451, 1407, 1381, 1355, 1142, 1095, $1019 . \operatorname{HRMS~(m/z):~}$ calculated for $\mathrm{C}_{9} \mathrm{H}_{10} \mathrm{FN}_{4}[\mathrm{M}+\mathrm{H}]^{+}$193.0884; found 193.0884.

\section{5-Phenyl-2-(1-phenylethyl)-2H-tetrazole (Table 2, 14)}

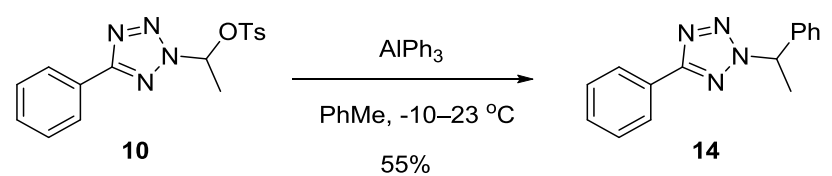

An oven-dried microwave vial was charged with triphenyl aluminum $(0.87 \mathrm{~mL}, 0.87 \mathrm{mmol}, 1.0$ $\mathrm{M}$ in dibutyl ether, 3.00 equiv). The reaction mixture was heated under vacuum at the mixture was heated at $50{ }^{\circ} \mathrm{C}$ to remove the dibutyl ether. The reaction mixture was cooled to room temperature and $\mathrm{PhMe}(0.80 \mathrm{~mL})$ was added. The reaction mixture was further cooled to $-10{ }^{\circ} \mathrm{C}$. 1-(5-Phenyl-2H-tetrazol-2-yl)ethyl 4-methylbenzenesulfonate ( $0.100 \mathrm{~g}, 0.290 \mathrm{mmol}, 1.00$ equiv) dissolved in $\mathrm{PhMe}(1.0 \mathrm{~mL})$ was added dropwise. The reaction mixture was maintained at $-10{ }^{\circ} \mathrm{C}$ for $3 \mathrm{~h}$, then warmed room temperature and stirred for $5 \mathrm{~h}$. The reaction mixture was poured into cold $1 \mathrm{M} \mathrm{HCl}(5 \mathrm{~mL})$, extracted with $\mathrm{CH}_{2} \mathrm{Cl}_{2}(3 \times 5 \mathrm{~mL})$. The combined organic layers were dried over $\mathrm{Na}_{2} \mathrm{SO}_{4}$, filtered, and concentrated in vacuo. The residue was purified by silica gel chromatography (gradient of $0-40 \%$ EtOAc in heptane (v/v)) to afford $39.8 \mathrm{mg}(55 \%$ yield) of the title compound (14).

NMR Spectroscopy: ${ }^{1} \mathrm{H}$ NMR (400 $\left.\mathrm{MHz}, \mathrm{CDCl}_{3}, 2{ }^{\circ} \mathrm{C}, \delta\right): 8.17-8.14(\mathrm{~m}, 2 \mathrm{H}), 7.51-7.31$ (m, $8 \mathrm{H}), 6.12$ (q, $J=7.0 \mathrm{~Hz}, 1 \mathrm{H}), 2.11(\mathrm{~d}, J=7.0 \mathrm{~Hz}, 3 \mathrm{H}) .{ }^{13} \mathrm{C} \mathrm{NMR}\left(101 \mathrm{MHz}, \mathrm{CDCl}_{3}, 25{ }^{\circ} \mathrm{C}, \delta\right)$ : $165.2,139.1,130.3,129.1,128.9,128.8,127.4,127.0,126.8,63.8,21.3$. IR (thin film, $\mathrm{cm}^{-1}$ ): $1528,1495,1465,1449,1329,1071,1039,1025,1006$. HRMS (m/z): calculated for $\mathrm{C}_{15} \mathrm{H}_{15} \mathrm{~N}_{4}$ $[\mathrm{M}+\mathrm{H}]^{+}$251.1291; found 251.1289. 


\section{Synthesis of 2 a using acetaldehyde- $d_{4}$}

\section{Ethyl (1-(5-phenyl-2H-tetrazol-2-yl)ethyl-1,2,2,2-d 4 ) carbonate (2a-d 4 )}

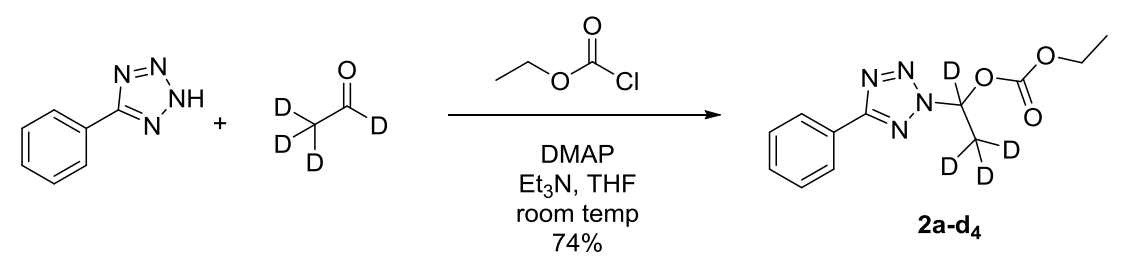

A flask was charged with 5-phenyl- $1 H$-tetrzole $(103 \mathrm{mg}, 0.706 \mathrm{mmol}, 1.00$ equiv) and THF (2 $\mathrm{mL})$. To the reaction mixture was added acetaldehyde- $\mathrm{d}_{4}(39.4 \mu \mathrm{L}, 0.705 \mathrm{mmol}, 1.00$ equiv), DMAP (5.3 mg, $43 \mu \mathrm{mol}, 6 \mathrm{~mol} \%$ ), triethylamine (108 $\mu \mathrm{L}, 0.777 \mathrm{mmol}, 1.10$ equiv), and lastly ethyl chloroformate $(70.9 \mu \mathrm{L}, 0.741 \mathrm{mmol}, 1.05$ equiv). The reaction mixture was allowed to stir at room temperature overnight and then diluted with water and transferred to a separatory funnel. The reaction mixture was extracted three times with EtOAc. The combined organic layers were dried over $\mathrm{MgSO}_{4}$, filtered, and concentrated in vacuo. The residue was filtered through a plug of silica gel, eluting with EtOAc. Concentration in vacuo afforded $139 \mathrm{mg}$ (74\% yield) of the title compound (2a-d $\left.\mathbf{d}_{\mathbf{4}}\right)$ as a colorless oil.

$\mathrm{R}_{f}=0.35$ (heptane/EtOAc 4:1 (v/v). NMR Spectroscopy: ${ }^{1} \mathrm{H}$ NMR (600 MHz, $\left.\mathrm{CDCl}_{3}, 25{ }^{\circ} \mathrm{C}, \delta\right)$ : 8.21-8.17 (m, 2H), 7.56-7.48 (m, 3H), 4.31-4.22 (m, 2H), $1.33(\mathrm{t}, J=7.0 \mathrm{~Hz}, 3 \mathrm{H}) .{ }^{13} \mathrm{C}$ NMR (125.8 MHz, $\left.\mathrm{CDCl}_{3}, 27{ }^{\circ} \mathrm{C}, \delta\right): 165.4,152.9,130.6,128.8,127.0,82.5(\mathrm{t}, J=25.2 \mathrm{~Hz}), 65.2,18.5$ (septet, $J=19.8 \mathrm{~Hz}$ ), 14.0. IR (thin film, $\mathrm{cm}^{-1}$ ): 1759, 1271, 1014, 993. HRMS (m/z): calculated for $\mathrm{C}_{12} \mathrm{H}_{10} \mathrm{D}_{4} \mathrm{~N}_{4} \mathrm{NaO}_{3}[\mathrm{M}+\mathrm{H}]^{+}$289.1209; found 289.1209.

\section{Optimization of DKR reaction parameters (Table 3 and Table S1)}

General procedure: A microwave vial was charged with 5-phenyl- $1 H$-tetrazole (26.7 mg, 0.183 mmol, 1.00 equiv) and catalyst ( $4 \mathrm{~mol} \%)$ and sealed with a septum cap. Solvent $(2.0 \mathrm{~mL})$ was added through the septum followed by base $(0.201 \mathrm{mmol}, 1.10$ equiv $)$ and acetaldehyde $(11.3 \mu \mathrm{L}$, $0.201 \mathrm{mmol}, 1.10$ equiv). Lastly, isobutyric anhydride $(39.5 \mu \mathrm{L}, 0.238 \mathrm{mmol}, 1.30$ equiv) was added. The reaction was stirred at the indicated temperature overnight. The reaction mixture was concentrated in vacuo and purified by column chromatography on silica gel using a gradient of EtOAc in heptane.

List of catalysts:

A: $(S)$-(-)-4-dimethylaminopyrindinyl(pentaphenylcyclopentadienyl)iron ((S)-C5Ph5-DMAP)

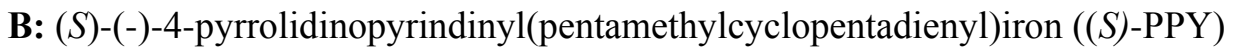

C: (S)-(4-(tert-butyl)-2-thioxothiazolidin-3-yl)(4-(dimethylamino)pyridin-3-yl)methanone

D: $(R)$-(4-benzyl-2-thioxothiazolidin-3-yl)(4-(dimethylamino)pyridin-3-yl)methanone

E: ((2S)-2-(bis(3,5-bis(trifluoromethyl)phenyl)hydroxymethyl)-1-pyrrolidinyl)(4-(1- 
pyrrolidinyl)-3-pyridinyl)methanone

F: ((2S)-2-(bis(3,5-dimethylphenyl)hydroxymethyl)-1-pyrrolidinyl)(4-(1-pyrrolidinyl)-3pyridinyl)methanone

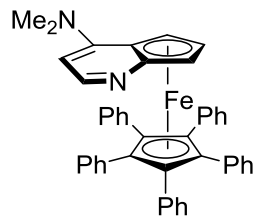

A: $(S)-C_{5} \mathrm{Ph}_{5}-\mathrm{DMAP}$
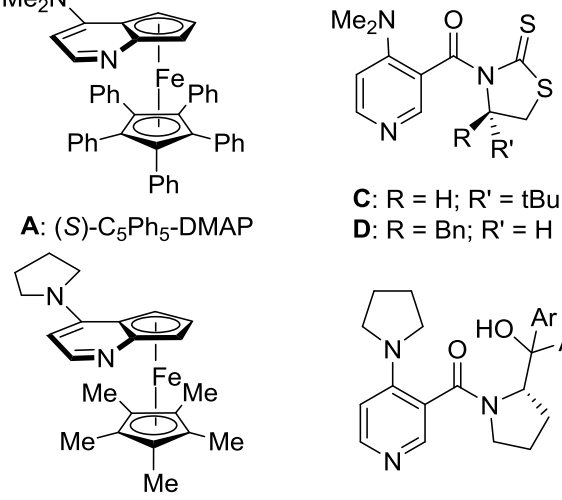

C: $\mathrm{R}=\mathrm{H} ; \mathrm{R}^{\prime}=\mathrm{tBu}$

D: $R=B n ; R^{\prime}=H$

B: (S)-PPY

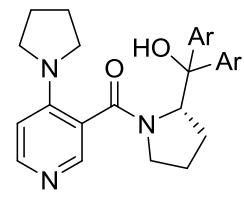

$\mathrm{E}: \mathrm{Ar}=3,5-\left(\mathrm{CF}_{3}\right)_{2}-\mathrm{C}_{6} \mathrm{H}_{3}$

$\mathbf{F}: \mathrm{Ar}=3,5-\mathrm{Me}_{2}-\mathrm{C}_{6} \mathrm{H}_{3}$ 
Table S1. Catalyst, base, solvent, and temperature variation

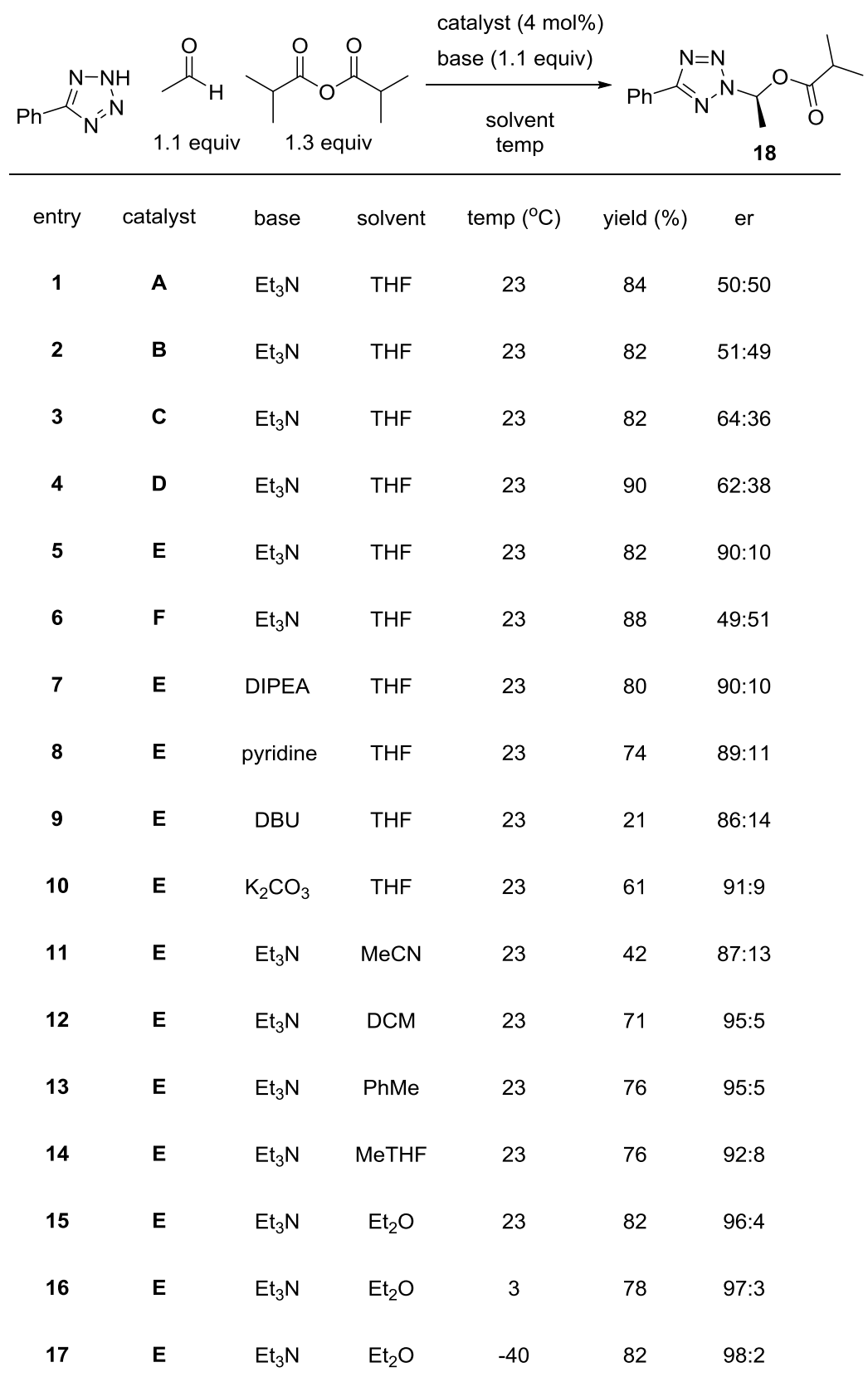

Generalized procedure for dynamic kinetic resolution (Table 4)

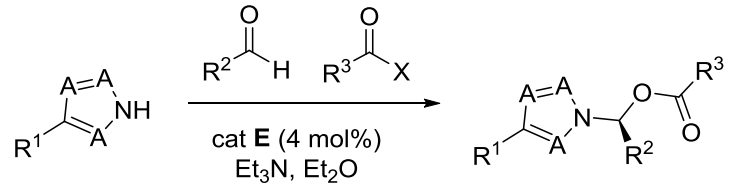

A microwave vial was charged with azole $(0.183 \mathrm{mmol}, 1.00$ equiv) and $\{(2 S)-2-\{$ bis[3,5bis(trifluoromethyl)phenyl]hydroxymethyl \}-1-pyrrolidinyl\}[4-(1-pyrrolidinyl)-3- 
pyridinyl]methanone (chiral DMAP catalyst E) $(4.9 \mathrm{mg}, 4 \mathrm{~mol} \%, 7.3 \mu \mathrm{mol})$ and sealed with a septum cap. $\mathrm{Et}_{2} \mathrm{O}(2.0 \mathrm{~mL})$ was added through the septum followed by triethylamine $(28.0 \mu \mathrm{L}$, $0.201 \mathrm{mmol}, 1.10$ equiv) and aldehyde ( $0.201 \mathrm{mmol}, 1.10$ equiv). Lastly, isobutyric anhydride (or equivalent reagent) $(39.5 \mu \mathrm{L}, 0.238 \mathrm{mmol}, 1.30$ equiv) was added. The reaction was stirred at room temperature overnight. The reaction mixture was concentrated in vacuo and purified by column chromatography on silica gel using a gradient of EtOAc in heptane.))

Notes:

No precautions to exclude air or moisture were taken.

Use of a commercially available solution of acetaldehyde (5.0 M in THF) had no discernible effect on yield or enantiomeric ratio of the product.

Reaction can be set up using a stock solution of reagents in solvent if the final reaction volume is similar ( 0.1 M, based on azole).

(S)-1-(5-Phenyl-2H-tetrazol-2-yl)ethyl isobutyrate (Table 4, 18)

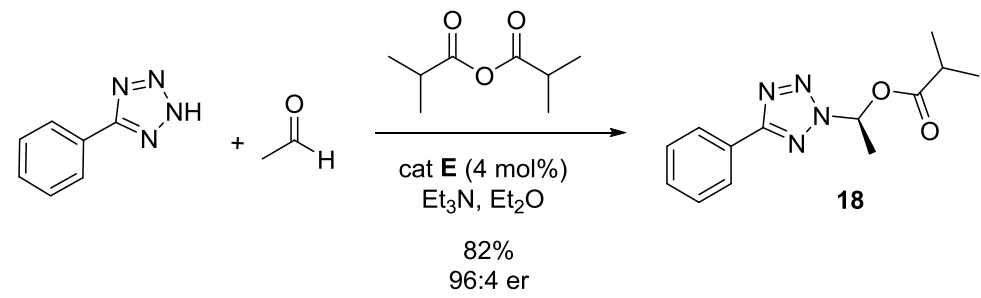

Isolated $39 \mathrm{mg}$ (82\% yield).

$\mathrm{R}_{f}=0.25$ (heptane/EtOAc 9:1 (v/v)). NMR Spectroscopy: ${ }^{1} \mathrm{H}$ NMR (400 MHz, $\left.\mathrm{CDCl}_{3}, 25^{\circ} \mathrm{C}, \delta\right)$ : 8.20-8.16 (m, 2H), 7.52-7.46 (m, 3H), 7.36 (q, J=6.2 Hz, 1H), 2.61 (qq, J=7.0, 7.0 Hz, 1H), 2.01 $(\mathrm{d}, J=6.2 \mathrm{~Hz}, 3 \mathrm{H}), 1.20$ (d, $J=7.0 \mathrm{~Hz}, 3 \mathrm{H}), 1.16(\mathrm{~d}, J=7.0 \mathrm{~Hz}, 3 \mathrm{H}) .{ }^{13} \mathrm{C} \mathrm{NMR}\left(101 \mathrm{MHz}, \mathrm{CDCl}_{3}\right.$, $25^{\circ} \mathrm{C}, \delta$ ): $175.0,165.4,130.7,129.0,127.2,127.2,80.1,33.9,19.5,18.7,18.7$. IR (thin film, $\mathrm{cm}^{-}$ $\left.{ }^{1}\right)$ : $1752,1468,1450,1135,1080,1018,732,693$. HRMS (m/z): calculated for $\mathrm{C}_{13} \mathrm{H}_{16} \mathrm{~N}_{4} \mathrm{NaO}_{2}[\mathrm{M}$ $+\mathrm{Na}]^{+}$283.1165; found 283.1168. Enantiomeric ratio (er) determination (Chiral Tech OJ-H column): 96:4.
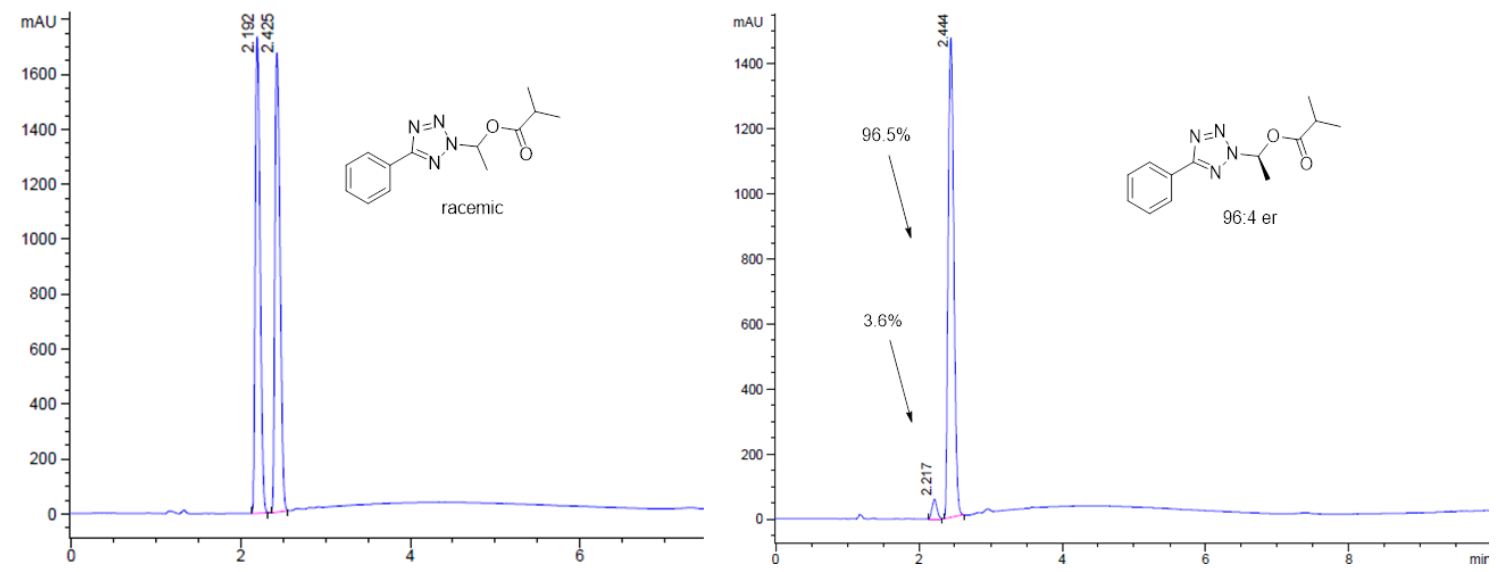
(S)-1-(5-Phenyl-2H-tetrazol-2-yl)propyl isobutyrate (Table 4, 19)
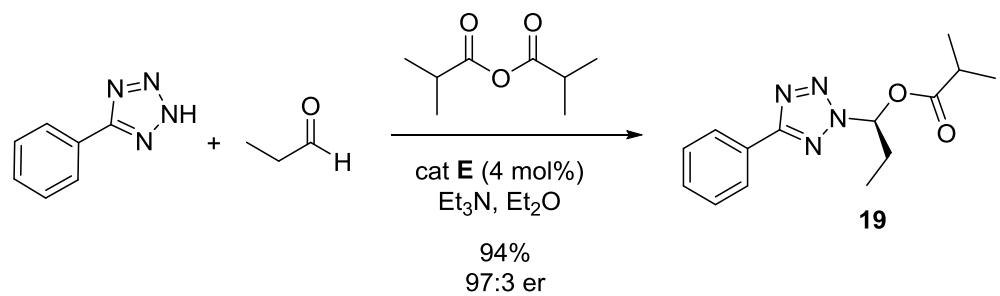

Isolated $47 \mathrm{mg}$ (94\% yield).

$\mathrm{R}_{f}=0.35$ (heptane/EtOAc 9:1 (v/v)). NMR Spectroscopy: ${ }^{1} \mathrm{H}$ NMR $\left(400 \mathrm{MHz}, \mathrm{CDCl}_{3}, 25^{\circ} \mathrm{C}, \delta\right)$ : $8.22-8.15(\mathrm{~m}, 2 \mathrm{H}), 7.52-7.45(\mathrm{~m}, 3 \mathrm{H}), 7.17$ (t, $J=7.0 \mathrm{~Hz}, 1 \mathrm{H}), 2.63$ (qq, $J=7.0,7.0 \mathrm{~Hz}, 1 \mathrm{H}), 2.49-$ $2.29(\mathrm{~m}, 2 \mathrm{H}), 1.21(\mathrm{~d}, J=7.0 \mathrm{~Hz}, 3 \mathrm{H}), 1.16(\mathrm{~d}, J=7.0 \mathrm{~Hz}, 3 \mathrm{H}), 0.99$ (dd, $J=7.6,7.6 \mathrm{~Hz}, 3 \mathrm{H}) .{ }^{13} \mathrm{C}$ NMR (101 MHz, $\left.\mathrm{CDCl}_{3}, 25^{\circ} \mathrm{C}, \delta\right): 175.1,165.3,130.7,129.0,127.3,127.2,84.0,33.9,26.8$, 18.8, 18.7, 8.7. IR (thin film, $\mathrm{cm}^{-1}$ ): 1755, 1467, 1450, 1133, 1093, 1022, 733, 693. HRMS $(\mathrm{m} / \mathrm{z})$ : calculated for $\mathrm{C}_{14} \mathrm{H}_{18} \mathrm{~N}_{4} \mathrm{NaO}_{2}[\mathrm{M}+\mathrm{Na}]^{+}$297.1322; found 297.1314. Enantiomeric ratio (er) determination (Lux Amylose-2 column): 97:3.
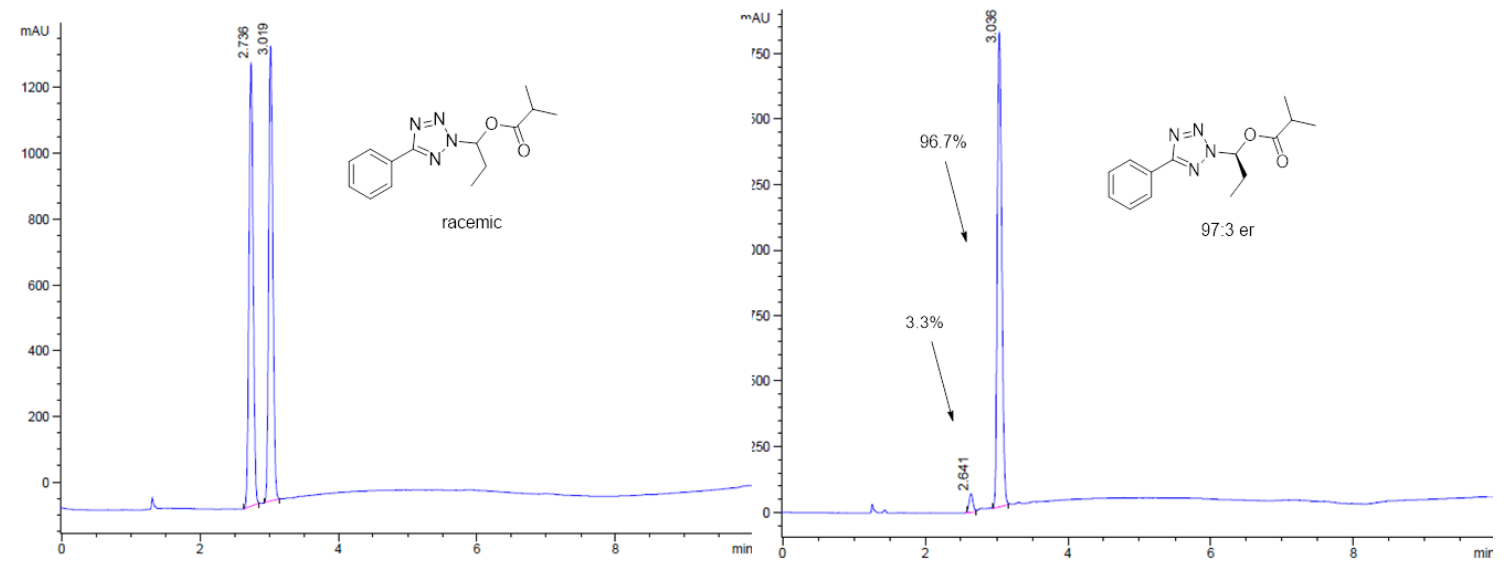

(S)-2-Methyl-1-(5-phenyl-2H-tetrazol-2-yl)propyl isobutyrate (Table 4, 20)
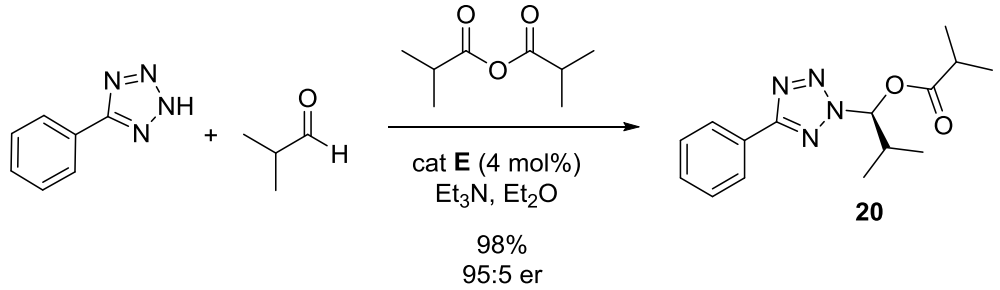

Isolated $52 \mathrm{mg}(98 \%$ yield).

$\mathrm{R}_{f}=0.38$ (heptane/EtOAc 9:1 (v/v)). NMR Spectroscopy: ${ }^{1} \mathrm{H}$ NMR $\left(400 \mathrm{MHz}, \mathrm{CDCl}_{3}, 25^{\circ} \mathrm{C}, \delta\right)$ : 8.21-8.15 (m, 2H), 7.52-7.45 (m, 3H), 6.94 (d, J=8.6 Hz, 1H), 2.83-2.70 (m, 1H), 2.66 (qq, 
$J=7.0,7.0 \mathrm{~Hz}, 1 \mathrm{H}), 1.22(\mathrm{~d}, J=7.0 \mathrm{~Hz}, 3 \mathrm{H}), 1.16(\mathrm{~d}, J=7.0 \mathrm{~Hz}, 3 \mathrm{H}), 1.13(\mathrm{~d}, J=6.6 \mathrm{~Hz}, 3 \mathrm{H}), 0.88$ $(\mathrm{d}, J=7.0 \mathrm{~Hz}, 3 \mathrm{H}) .{ }^{13} \mathrm{C} \mathrm{NMR}\left(101 \mathrm{MHz}, \mathrm{CDCl}_{3}, 25{ }^{\circ} \mathrm{C}, \delta\right): 175.1,165.2,130.6,129.0,127.3$, 127.2, 87.0, 33.9, 32.4, 18.9, 18.6, 17.7, 17.5. IR (thin film, $\mathrm{cm}^{-1}$ ): 1756, 1468, 1450, 1132, 1095 , 1017, 732, 692. HRMS (m/z): calculated for $\mathrm{C}_{15} \mathrm{H}_{21} \mathrm{~N}_{4} \mathrm{O}_{2}[\mathrm{M}+\mathrm{H}]^{+}$289.1659; found 289.1651. Enantiomeric ratio (er) determination (Lux Amylose-2 column): 95:5.
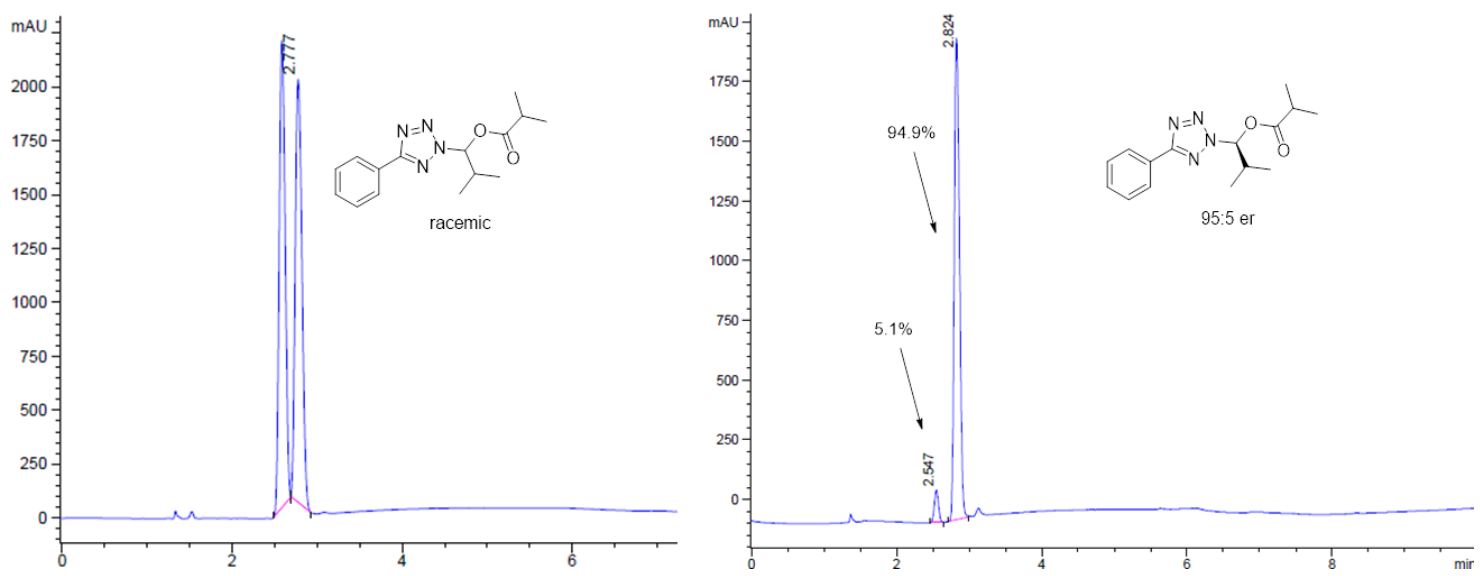

(S)-Phenyl(5-phenyl-2H-tetrazol-2-yl)methyl isobutyrate (Table 4, 21)

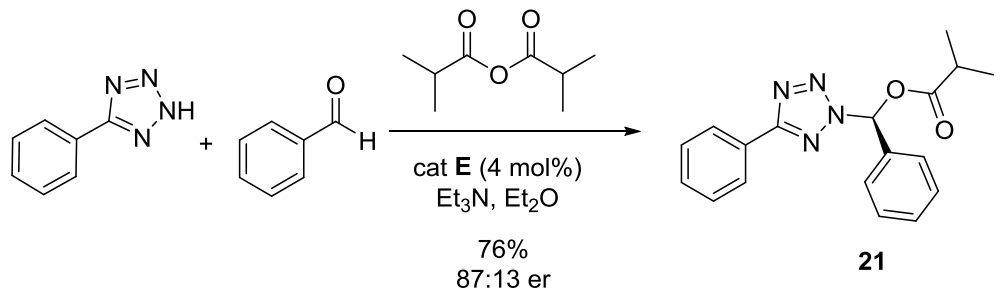

Isolated $45 \mathrm{mg}$ (76\% yield).

$\mathrm{R}_{f}=0.26$ (heptane/EtOAc 9:1 (v/v)). NMR Spectroscopy: ${ }^{1} \mathrm{H}$ NMR $\left(400 \mathrm{MHz}, \mathrm{CDCl}_{3}, 25{ }^{\circ} \mathrm{C}, \delta\right)$ : $8.20(\mathrm{~s}, 1 \mathrm{H}), 8.18-8.11(\mathrm{~m}, 2 \mathrm{H}), 7.67-7.59(\mathrm{~m}, 2 \mathrm{H}), 7.51-7.41(\mathrm{~m}, 6 \mathrm{H}), 2.76$ (qq, J=7.0, $7.0 \mathrm{~Hz}$, $1 \mathrm{H}), 1.26(\mathrm{~d}, J=6.4 \mathrm{~Hz}, 3 \mathrm{H}), 1.24(\mathrm{~d}, J=6.4 \mathrm{~Hz}, 3 \mathrm{H}) .{ }^{13} \mathrm{C} \mathrm{NMR}\left(101 \mathrm{MHz}, \mathrm{CDCl}_{3}, 25{ }^{\circ} \mathrm{C}, \delta\right)$ : 174.6, 165.5, 133.5, 130.7, 130.4, 129.1, $129.0127 .2,83.4,34.0,18.7,18.7$. IR (thin film, $\mathrm{cm}^{-1}$ ): 1757, 1467, 1450, 1093, 1017, 731, 692. HRMS (m/z): calculated for $\mathrm{C}_{18} \mathrm{H}_{18} \mathrm{~N}_{4} \mathrm{NaO}_{2}\left[\mathrm{M}+\mathrm{Na}^{+}\right.$ 345.1322; found 345.1329. Enantiomeric ratio (er) determination (Chiral Tech AD-H column): $87: 13$. 

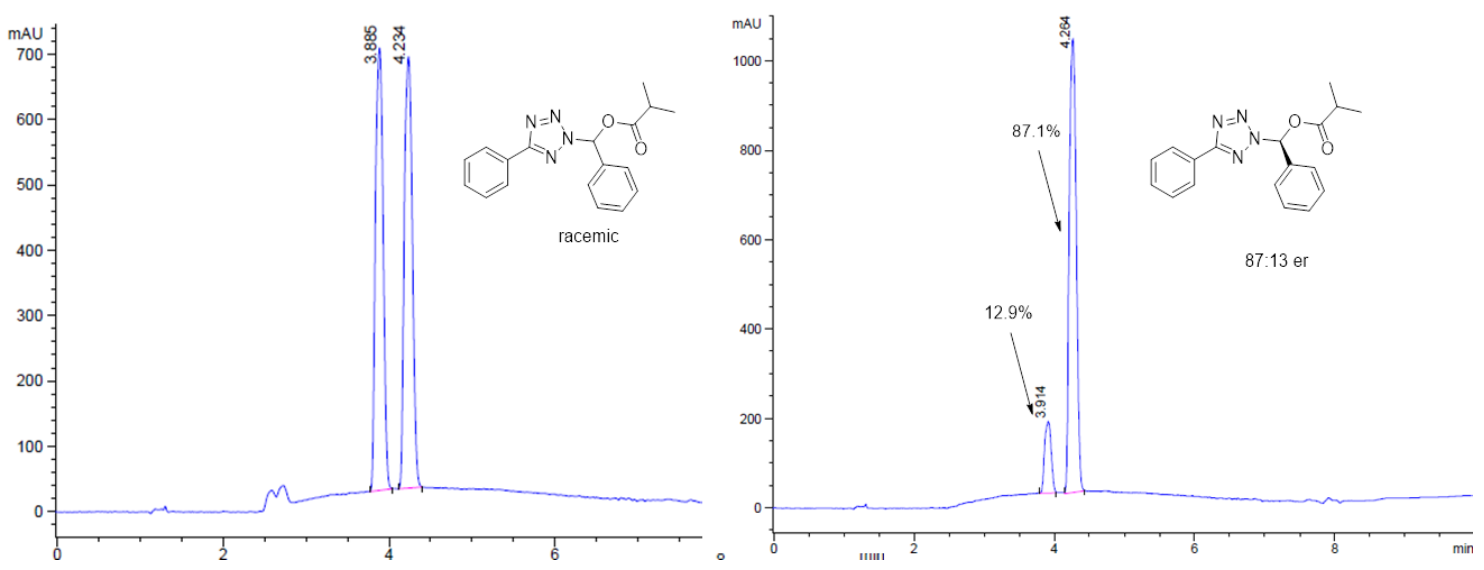

(S)-1-(5-Phenyl-2H-tetrazol-2-yl)ethyl propionate (Table 4, 22)

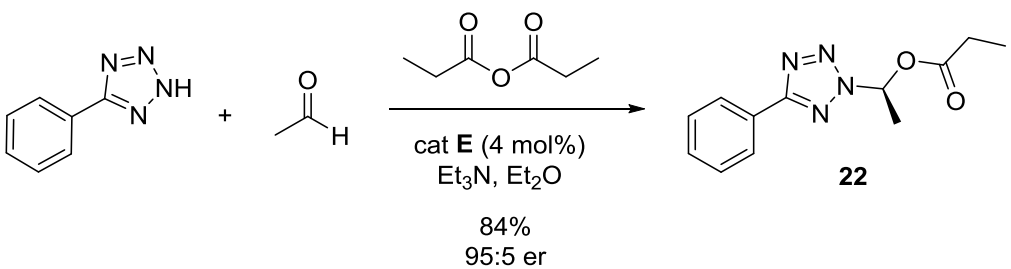

Note: Reaction performed using propionic anhydride $(30.7 \mu \mathrm{L}, 0.238 \mathrm{mmol}, 1.30$ equiv) instead of isobutyric anhydride

Isolated $38 \mathrm{mg}$ ( $84 \%$ yield).

$\mathrm{R}_{f}=0.30$ (heptane/EtOAc 9:1 (v/v)). NMR Spectroscopy: ${ }^{1} \mathrm{H}$ NMR (400 MHz, $\left.\mathrm{CDCl}_{3}, 25{ }^{\circ} \mathrm{C}, \delta\right)$ : 8.21-8.14 (m, 2H), 7.53-7.45 (m, 3H), 7.38 (q, $J=6.2 \mathrm{~Hz}, 1 \mathrm{H}), 2.40$ (dq, $J=1.8,7.5 \mathrm{~Hz}, 2 \mathrm{H}), 2.01$ $(\mathrm{d}, J=6.2 \mathrm{~Hz}, 3 \mathrm{H}), 1.15$ (t, $J=7.6 \mathrm{~Hz}, 3 \mathrm{H}) .{ }^{13} \mathrm{C} \mathrm{NMR}\left(101 \mathrm{MHz}, \mathrm{CDCl}_{3}, 25{ }^{\circ} \mathrm{C}, \delta\right): 172.3,165.4$, $130.7,129.0,127.2,80.0,27.4,19.5,8.8$. IR (thin film, $\mathrm{cm}^{-1}$ ): 1756, 1467, 1450, 1149, 1086, 1038, 1019, 906, 733, 693. HRMS (m/z): calculated for $\mathrm{C}_{12} \mathrm{H}_{14} \mathrm{~N}_{4} \mathrm{NaO}_{2}[\mathrm{M}+\mathrm{Na}]^{+}$269.1009; found 269.0999. Enantiomeric ratio (er) determination (Chiral Tech OJ-H column): 95:5.
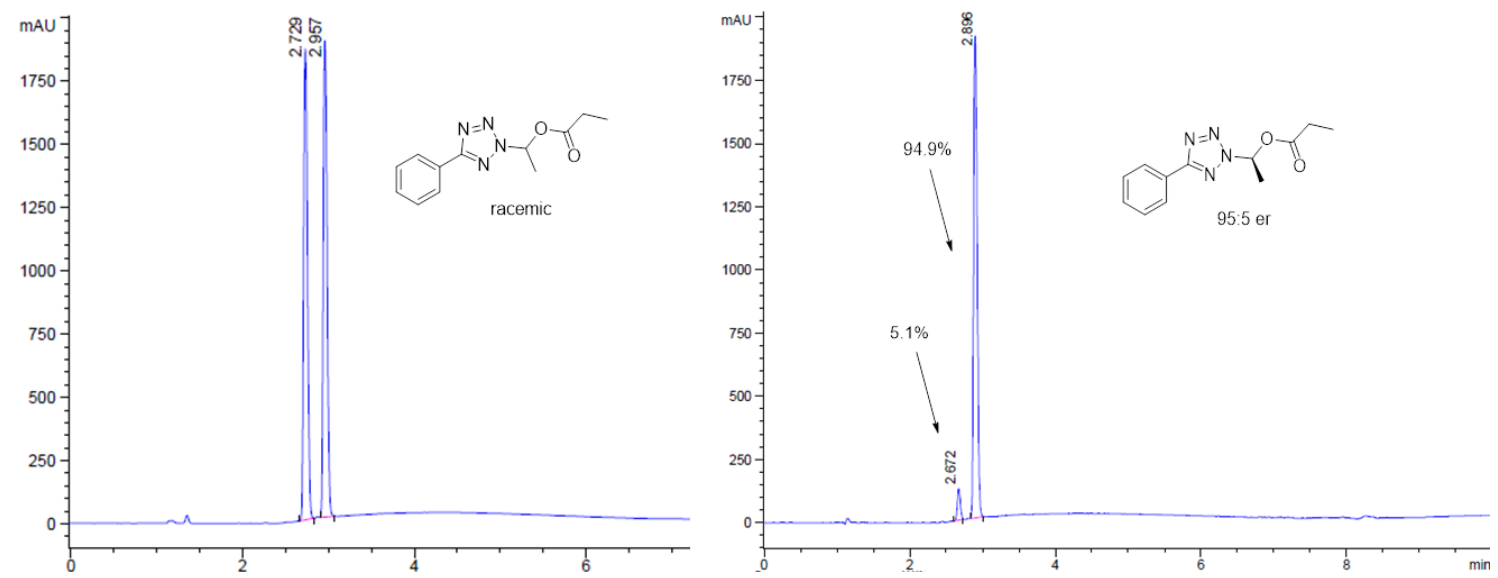
(S)-Ethyl (1-(5-phenyl-2H-tetrazol-2-yl)ethyl) carbonate (Table 4, 23 ((S)-2a))
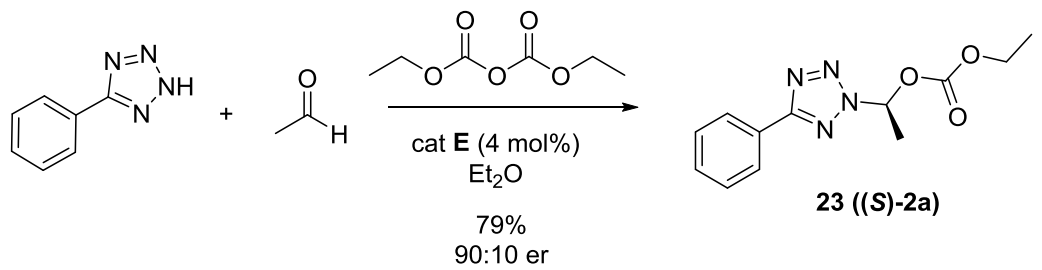

Note: Reaction performed using diethyl pyrocarbonate ( $40.3 \mu \mathrm{L}, 0.274 \mathrm{mmol}, 1.50$ equiv) instead of isobutyric anhydride and $\mathrm{Et}_{3} \mathrm{~N}$ was omitted.

Isolated $38 \mathrm{mg}$ (79\% yield).

See compound $\mathbf{2 a}$ above for full characterization.

Enantiomeric ratio (er) determination (Chiral Tech OJ-H column): 90:10.
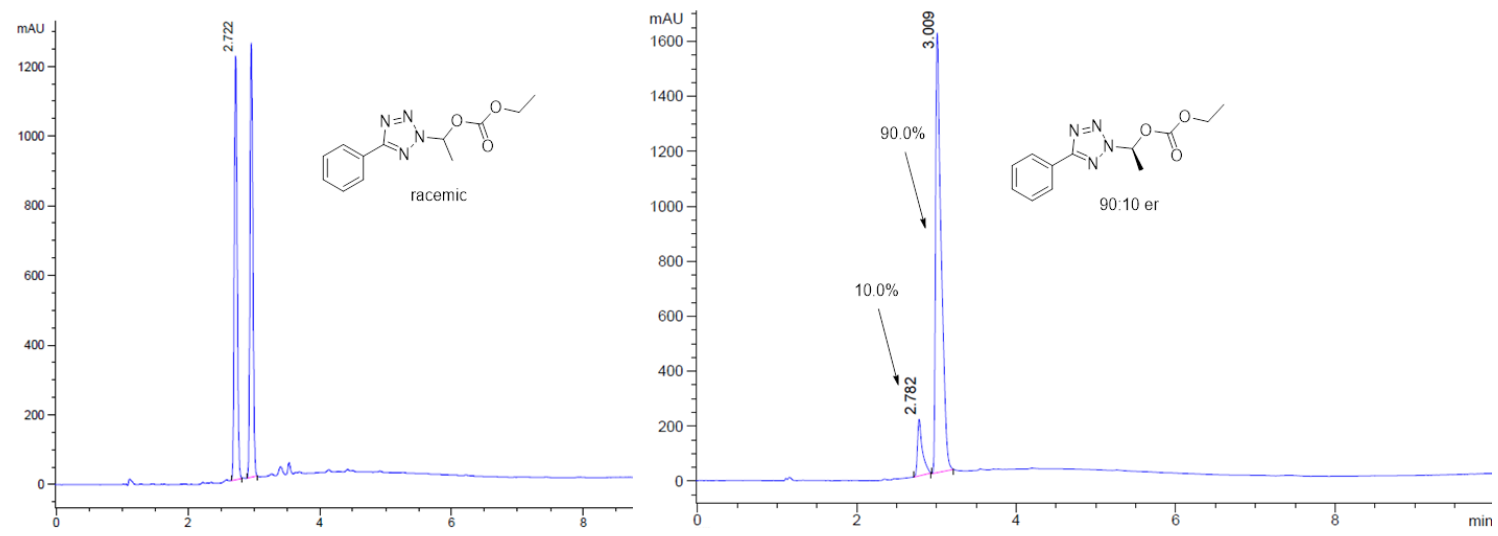

(S)-(4-Bromophenyl)(5-phenyl-2H-tetrazol-2-yl)methyl isobutyrate (Table 4, $24((S)-9))$
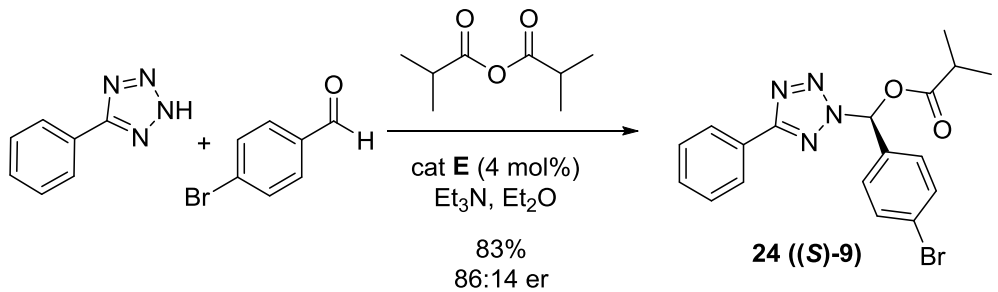

Note: Reaction performed on $0.684 \mathrm{mmol}$ of tetrazole and scaling other reagents proportionally.

Isolated $228 \mathrm{mg}$ ( $83 \%$ yield).

See compound 9 above for full characterization.

Enantiomeric ratio (er) determination (Chiral Tech OJ-H column): 86:14. 

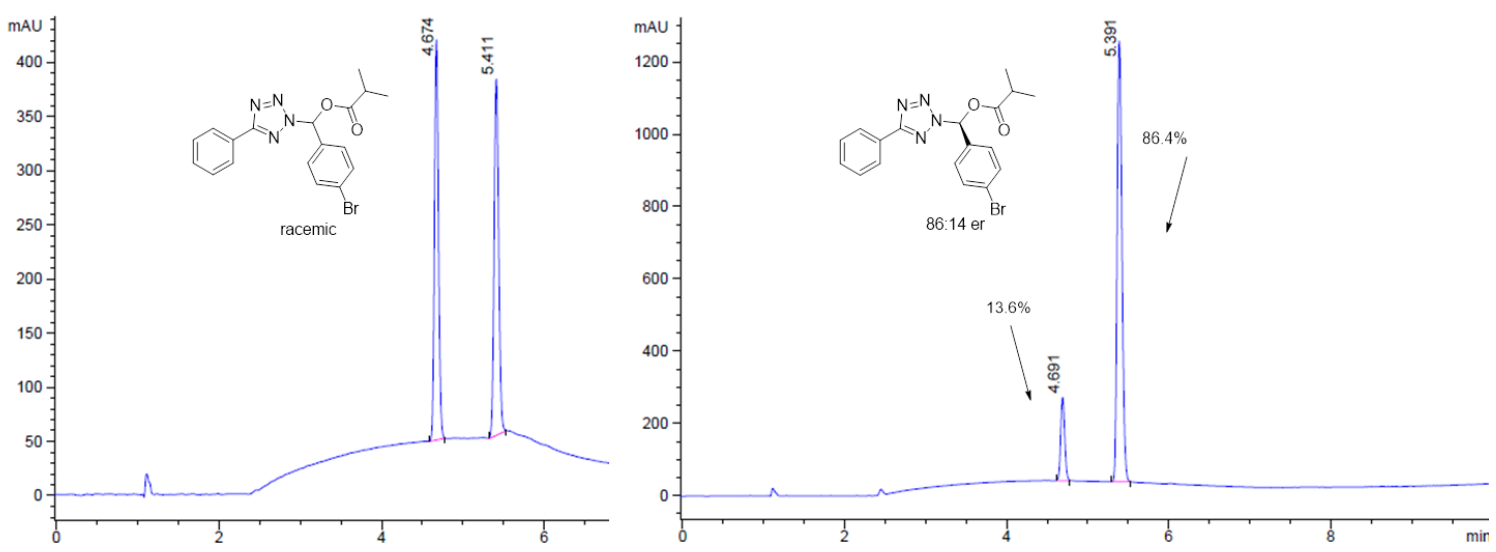

(S)-(3'-Fluoro-4'-nitro-[1,1'-biphenyl]-4-yl)(5-phenyl-2H-tetrazol-2-yl)methyl isobutyrate (S-2)

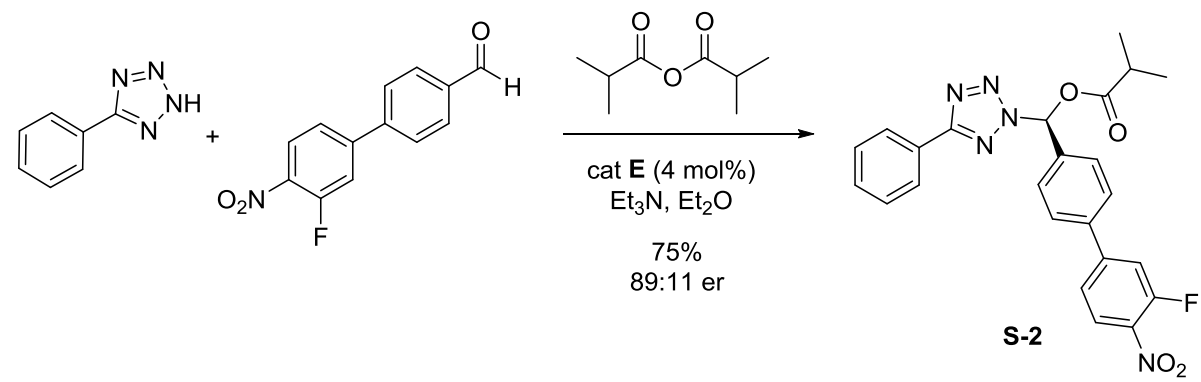

Note: Reaction performed on $0.712 \mathrm{mmol}$ of tetrazole and scaling other reagents proportionally.

Isolated $245 \mathrm{mg}$ (75\% yield).

$\mathrm{R}_{f}=0.49$ (heptane/EtOAc 4:1 (v/v)). NMR Spectroscopy: ${ }^{1} \mathrm{H}$ NMR $\left(400 \mathrm{MHz}, \mathrm{CDCl}_{3}, 25{ }^{\circ} \mathrm{C}, \delta\right)$ : $8.26(\mathrm{~s}, 1 \mathrm{H}), 8.18-8.15(\mathrm{~m}, 3 \mathrm{H}), 7.79-7.76(\mathrm{~m}, 2 \mathrm{H}), 7.70-7.68(\mathrm{~m}, 2 \mathrm{H}), 7.51-7.46(\mathrm{~m}, 5 \mathrm{H}), 2.79$ (qq, $J=7.0,7.0 \mathrm{~Hz}, 1 \mathrm{H}), 1.28(\mathrm{~d}, J=7.0 \mathrm{~Hz}, 3 \mathrm{H}), 1.26(\mathrm{~d}, J=7.0 \mathrm{~Hz}, 3 \mathrm{H}) .{ }^{13} \mathrm{C}$ NMR $(101 \mathrm{MHz}$, $\mathrm{CDCl}_{3}, 25^{\circ} \mathrm{C}, \delta$ ): 174.6, 165.7, 156.0 (d, $J=260 \mathrm{~Hz}$ ), 148.0 (d, $\left.J=8 \mathrm{~Hz}\right), 139.7,136.6,134.7$, 130.8, 129.1, 128.2, 128.1, 127.2, 127.0 (d, $J=7 \mathrm{~Hz}), 123.2,123.2,117.0$ (d, $J=23 \mathrm{~Hz}), 82.9,34.0$, 18.8, 18.7. Enantiomeric ratio (er) determination (Chiral Tech AS-H column, EtOH instead of $\mathrm{MeOH}): 89: 11$. 

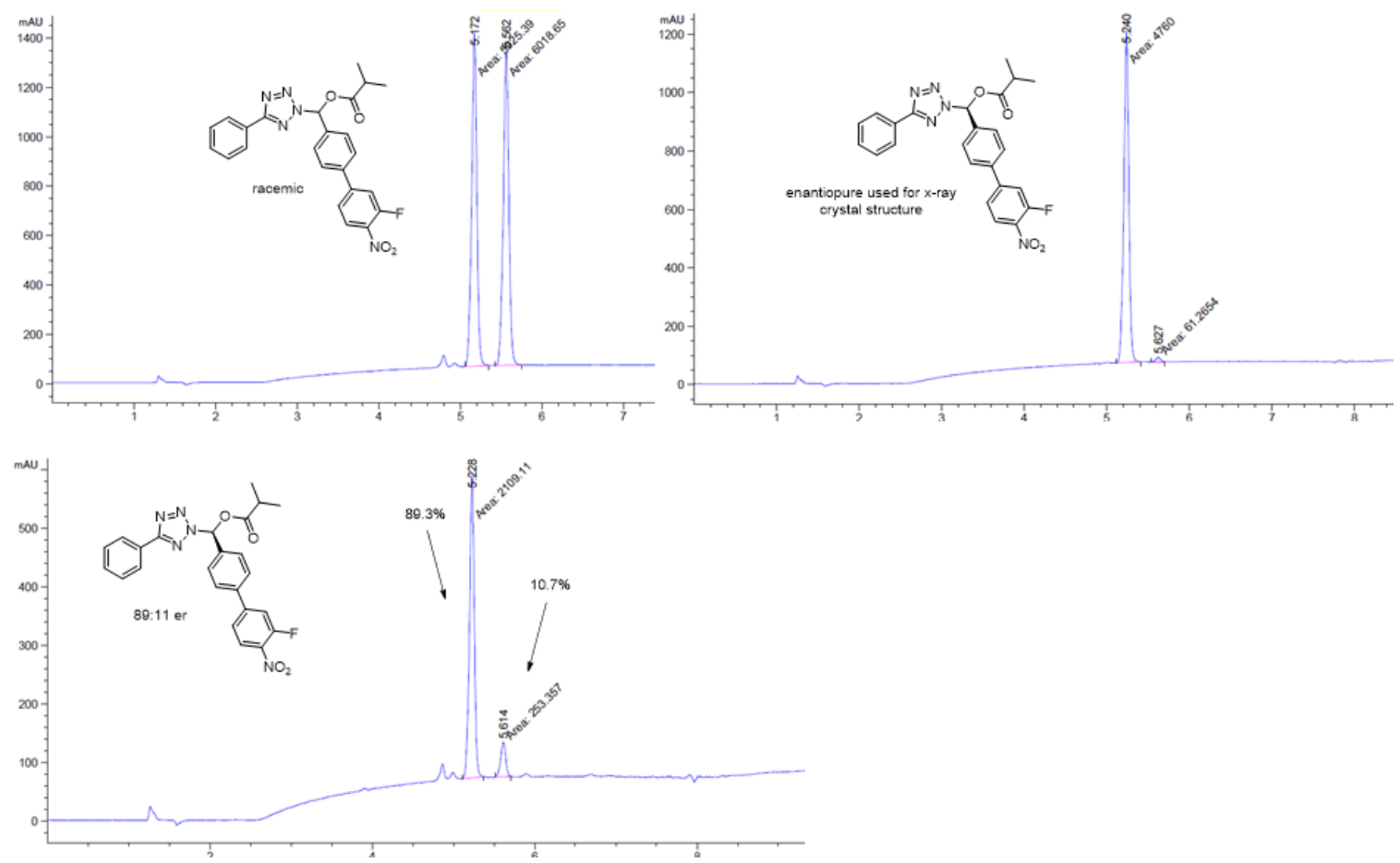

The major enantiomer was isolated by chiral preparatory SFC. An X-ray crystal structure of S-2 was obtained (see X-ray results, Figure S6, and Table S4 below). The absolute stereochemistry of the major enantiomer was $S$. The absolute stereochemistry of other aromatic-aldehyde-derived products isolated from the dynamic kinetic resolution reaction was assigned by analogy.

(S)-Ethyl (1-(5-(4-iodo-1-methyl-1H-pyrazol-5-yl)-2H-tetrazol-2-yl)ethyl) carbonate (Table $4,25((S)-7))$
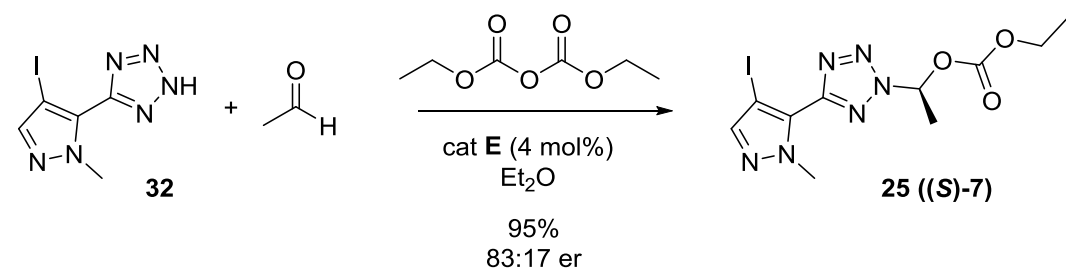

Note: Reaction performed using diethyl pyrocarbonate $(40.3 \mu \mathrm{L}, 0.274 \mathrm{mmol}, 1.50$ equiv) instead of isobutyric anhydride and $\mathrm{Et}_{3} \mathrm{~N}$ was omitted.

Isolated $68 \mathrm{mg}$ (95\% yield).

See compound 7 above for full characterization.

Enantiomeric ratio (er) determination (Chiral Tech IA-H column): 83:17. 

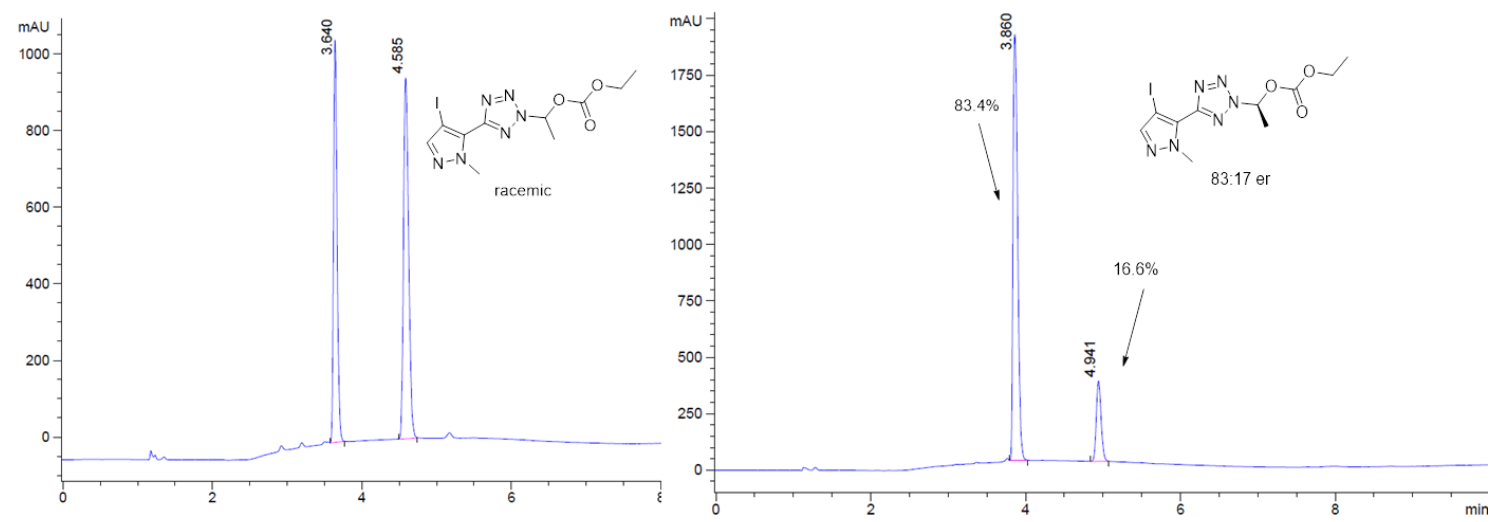

The major enantiomer was isolated by chiral preparatory SFC. An X-ray crystal structure of 25 was obtained (see X-ray results, Figure S7 and Table S5 below). The absolute stereochemistry of the major enantiomer was $S$. The absolute stereochemistry of other aliphatic-aldehyde-derived products isolated from the dynamic kinetic resolution reaction was assigned by analogy.

(S)-2-Methyl-1-(5-(4'-methyl-[1,1'-biphenyl]-2-yl)-2H-tetrazol-2-yl)propyl

isobutyrate (Table 4, 26)
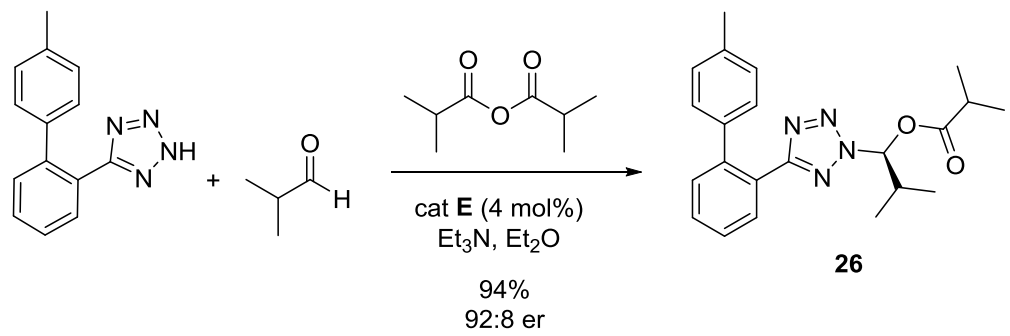

Note: Reaction performed on $0.423 \mathrm{mmol}$ of tetrazole and $5 \mathrm{~mol} \%$ cat $\mathbf{E}$ and scaling other reagents proportionally.

Isolated $150 \mathrm{mg}$ (94\% yield).

$\mathrm{R}_{f}=0.40$ (heptane/EtOAc 4:1 (v/v)). NMR Spectroscopy: ${ }^{1} \mathrm{H}$ NMR $\left(400 \mathrm{MHz}, \mathrm{CDCl}_{3}, 25{ }^{\circ} \mathrm{C}, \delta\right)$ : $7.80(\mathrm{~d}, J=7.8 \mathrm{~Hz}, 1 \mathrm{H}), 7.55-7.51(\mathrm{~m}, 1 \mathrm{H}), 7.47-7.43(\mathrm{~m}, 2 \mathrm{H}), 7.07-7.03(\mathrm{~m}, 4 \mathrm{H}), 6.80$ (d, $J=8.6$ $\mathrm{Hz}, 1 \mathrm{H}), 2.62-2.43$ (m, 2H), 2.33 (s, 3H), 1.17 (d, J=7.0 Hz, 3H), 1.11 (d, J=7.0 Hz, 3H), 0.98 (d, $J=6.6 \mathrm{~Hz}, 3 \mathrm{H}), 0.69$ (d, $J=6.6 \mathrm{~Hz}, 3 \mathrm{H}) .{ }^{13} \mathrm{C} \mathrm{NMR}\left(101 \mathrm{MHz}, \mathrm{CDCl}_{3}, 25{ }^{\circ} \mathrm{C}, \delta\right): 175.0,165.5$, $142.5,138.0,136.7,130.8,130.6,130.2,129.2,128.8,127.4,126.3,86.7,33.9,32.3,21.2,18.8$, 18.6, 17.5, 17.3. IR (thin film, $\mathrm{cm}^{-1}$ ): 1757, 1469, 1132, 1097, 1019, 820, 761. HRMS (m/z): calculated for $\mathrm{C}_{22} \mathrm{H}_{27} \mathrm{~N}_{4} \mathrm{O}_{2}[\mathrm{M}+\mathrm{H}]^{+}$379.2129; found 379.2136. Enantiomeric ratio (er) determination (Chiral Tech IC column): 92:8. 

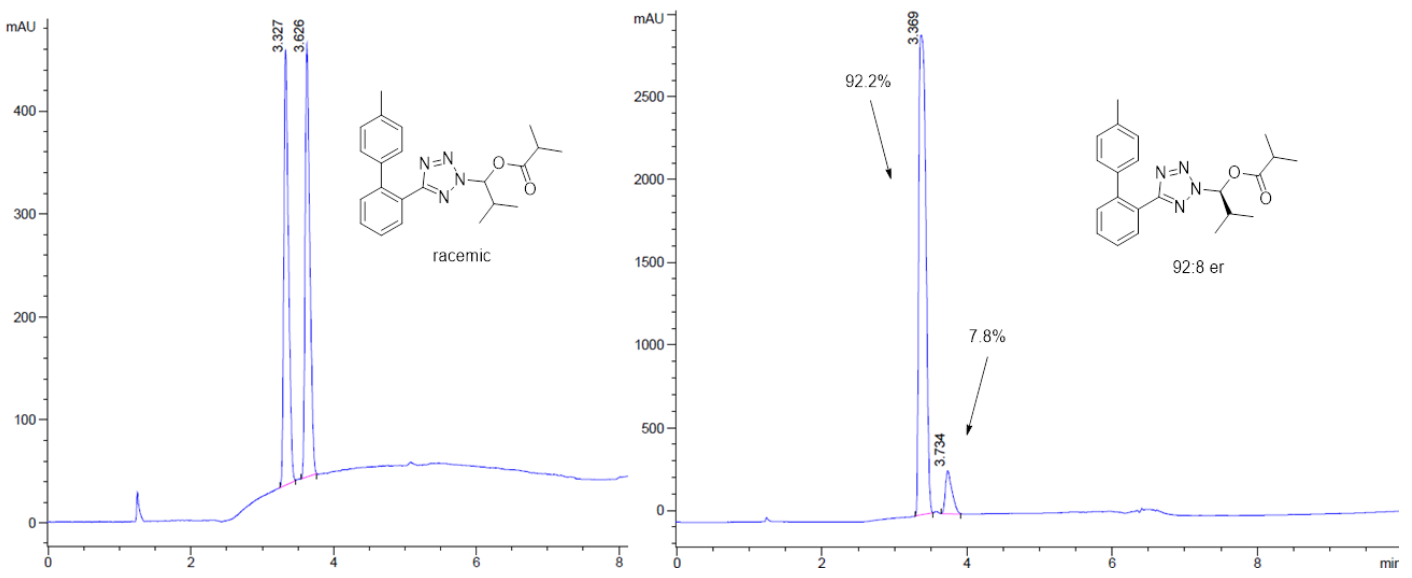

(S)-1-(4-Phenyl-1H-pyrazol-1-yl)ethyl isobutyrate (Table 4, 27)

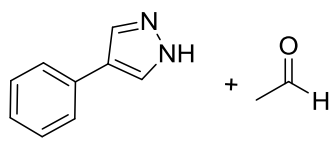

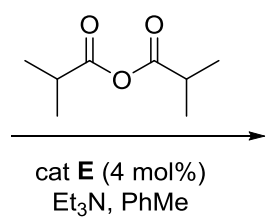

$70 \%$ $89: 11$ er

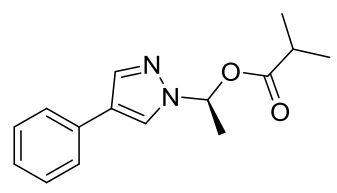

27

Note: PhMe used as solvent.

Isolated $33 \mathrm{mg}$ (70\% yield).

$\mathrm{R}_{f}=0.15$ (heptane/EtOAc 9:1 (v/v)). NMR Spectroscopy: ${ }^{1} \mathrm{H}$ NMR $\left(400 \mathrm{MHz}, \mathrm{CDCl}_{3}, 25{ }^{\circ} \mathrm{C}, \delta\right)$ : 7.87-7.85 (m, 2H), 7.50-7.48 (m, 2H), 7.38-7.34 (m, 2H), 7.27-7.21 (m, 1H), 6.84 (q, J=6.2 Hz, $1 \mathrm{H}), 2.55$ (qq, $J=7.0,7.0 \mathrm{~Hz}, 1 \mathrm{H}), 1.89$ (d, $J=6.2 \mathrm{~Hz}, 3 \mathrm{H}), 1.17$ (d, $J=7.0 \mathrm{~Hz}, 3 \mathrm{H}), 1.11$ (d, $J=7.0$ $\mathrm{Hz}, 3 \mathrm{H}) .{ }^{13} \mathrm{C} \mathrm{NMR}\left(101 \mathrm{MHz}, \mathrm{CDCl}_{3}, 25^{\circ} \mathrm{C}, \delta\right): 176.1,138.1,132.2,129.0,126.8,126.4,125.8$, 123.5, 79.1, 33.9, 19.3, 18.8, 18.7. IR (thin film, $\mathrm{cm}^{-1}$ ): 1737, 1182, 1144, 1080, 1062, 759, 695. $\operatorname{HRMS}(\mathrm{m} / \mathrm{z})$ : calculated for $\mathrm{C}_{15} \mathrm{H}_{19} \mathrm{~N}_{2} \mathrm{O}_{2}[\mathrm{M}+\mathrm{H}]^{+} 259.1441$; found 259.1439. Enantiomeric ratio (er) determination (Lux Amylose-2 column; eluent B: methanol + 0.2\% ammonia): 89:11.
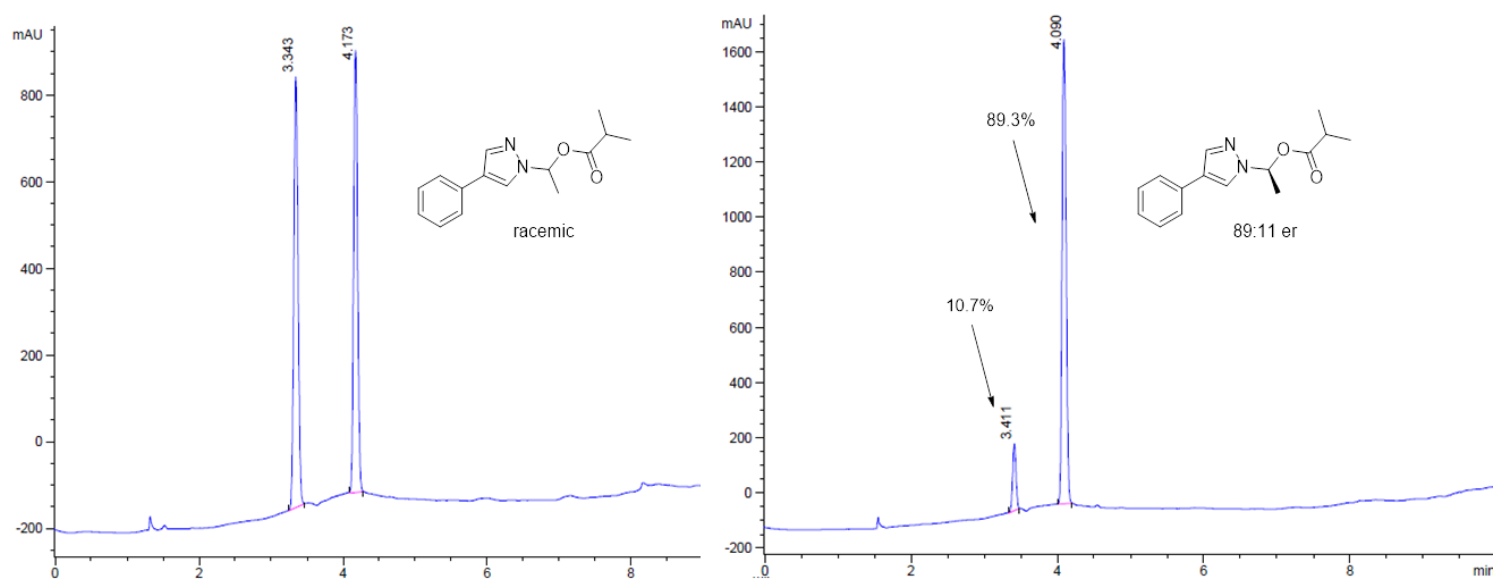


\section{(S)-1-(3-Phenyl-1H-pyrazol-1-yl)ethyl isobutyrate (Table 4, 28)}
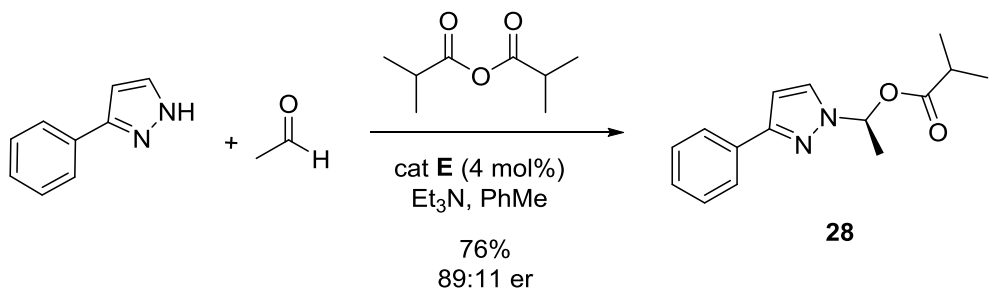

28

Note: PhMe used as solvent.

Isolated $36 \mathrm{mg}$ (76\% yield).

$\mathrm{R}_{f}=0.25$ (heptane/EtOAc 9:1 (v/v)). NMR Spectroscopy: ${ }^{1} \mathrm{H}$ NMR $\left(400 \mathrm{MHz}, \mathrm{CDCl}_{3}, 25{ }^{\circ} \mathrm{C}, \delta\right)$ : 7.85-7.82 (m, 2H), 7.64 (d, $J=2.3 \mathrm{~Hz}, 1 \mathrm{H}), 7.42-7.38$ (m, 2H), 7.34-7.28 (m, 1H), 6.83 (q, $J=6.2$ $\mathrm{Hz}, 1 \mathrm{H}), 6.58$ (d, $J=2.3 \mathrm{~Hz}, 1 \mathrm{H}), 2.55$ (qq, $J=7.0,7.0 \mathrm{~Hz}, 1 \mathrm{H}), 1.91$ (d, $J=6.2 \mathrm{~Hz}, 3 \mathrm{H}), 1.17$ (d, $J=7.0 \mathrm{~Hz}, 3 \mathrm{H}), 1.11(\mathrm{~d}, J=7.0 \mathrm{~Hz}, 3 \mathrm{H}) .{ }^{13} \mathrm{C} \mathrm{NMR}\left(101 \mathrm{MHz}, \mathrm{CDCl}_{3}, 25{ }^{\circ} \mathrm{C}, \delta\right): 176.2,152.4$, 133.4, 131.0, 128.7, 128.0, 126.0, 103.6, 79.4, 34.0, 19.4, 18.9, 18.7. IR (thin film, $\mathrm{cm}^{-1}$ ): 1736, $1457,1186,1145,1073,1020,752,730,694$. HRMS (m/z): calculated for $\mathrm{C}_{15} \mathrm{H}_{19} \mathrm{~N}_{2} \mathrm{O}_{2}[\mathrm{M}+\mathrm{H}]^{+}$ 259.1441; found 259.1441. Regiochemistry was assigned after observing a correlation (HMBC experiment) between the hemiaminal methine proton $(6.83 \mathrm{ppm})$ and the $\mathrm{C}_{5}$-carbon of the pyrazole (131.0 ppm). Enantiomeric ratio (er) determination (Chiral Tech OD column): 89:11.
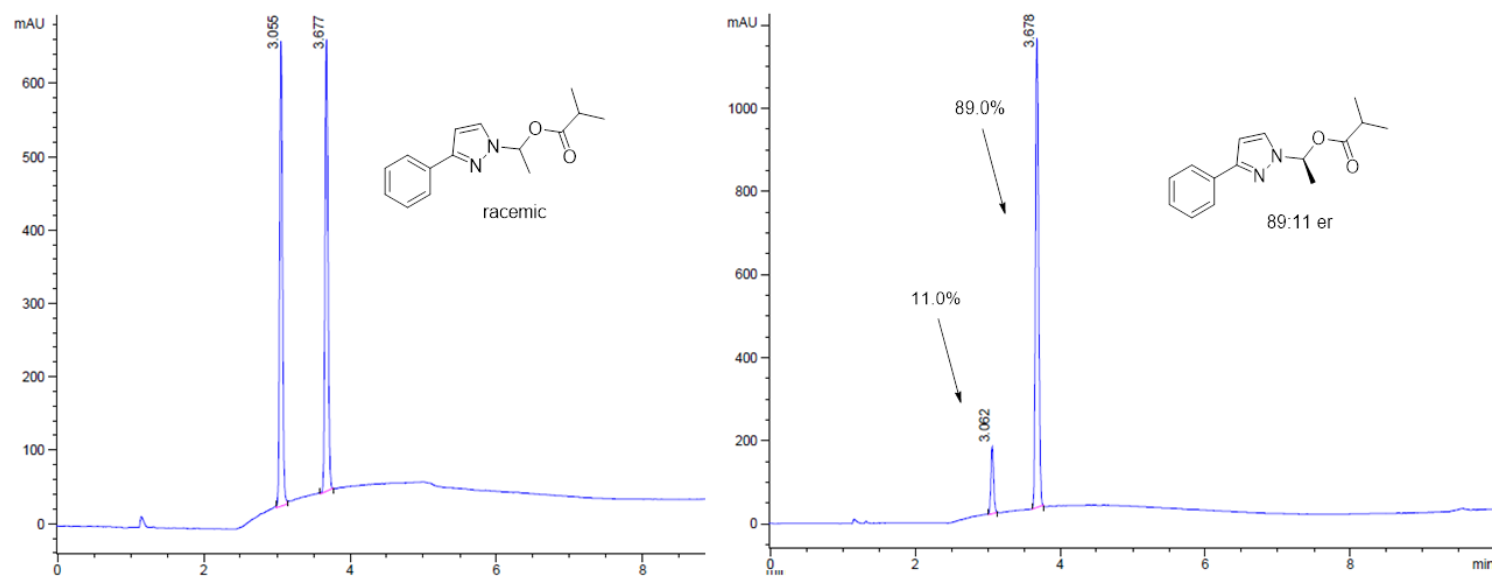

(S)-1-(4-Phenyl-1H-imidazol-1-yl)ethyl isobutyrate (Table 4, 29)

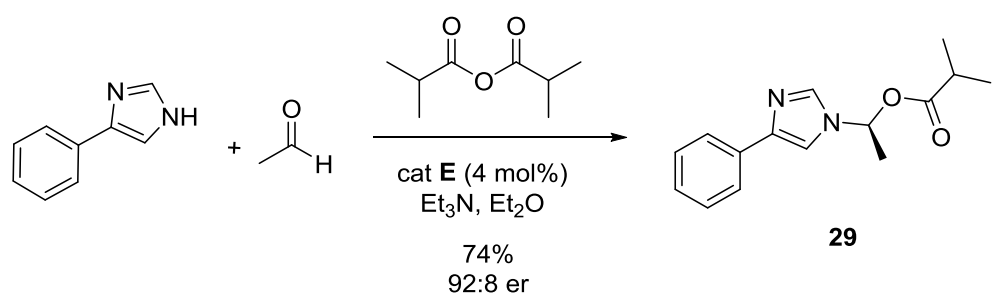


Isolated $35 \mathrm{mg}$ (74\% yield).

$\mathrm{R}_{f}=0.22$ (heptane/EtOAc 3:2 (v/v)). NMR Spectroscopy: ${ }^{1} \mathrm{H}$ NMR $\left(400 \mathrm{MHz}, \mathrm{CDCl}_{3}, 25{ }^{\circ} \mathrm{C}, \delta\right)$ : 7.79-7.77 (m, 3H), 7.39-7.36 (m, 3H), 7.27-7.23 (m, 1H), 6.72 (q, J=6.2 Hz, 1H), 2.53 (qq, $J=7.0,7.0 \mathrm{~Hz}, 1 \mathrm{H}), 1.82(\mathrm{~d}, J=6.2 \mathrm{~Hz}, 3 \mathrm{H}), 1.16(\mathrm{~d}, J=7.0 \mathrm{~Hz}, 3 \mathrm{H}), 1.11(\mathrm{~d}, J=7.0 \mathrm{~Hz}, 3 \mathrm{H}) .{ }^{13} \mathrm{C}$ $\operatorname{NMR}\left(101 \mathrm{MHz}, \mathrm{CDCl}_{3}, 25^{\circ} \mathrm{C}, \delta\right): 175.8,142.4,136.6,133.6,128.8,127.3,125.1,112.4,75.4$, 33.9, 20.4, 18.7, 18.7. IR (thin film, $\mathrm{cm}^{-1}$ ): 1740, 1186, 1142, 1085, 1044, 749, 695. HRMS $(\mathrm{m} / \mathrm{z})$ : calculated for $\mathrm{C}_{15} \mathrm{H}_{19} \mathrm{~N}_{2} \mathrm{O}_{2}[\mathrm{M}+\mathrm{H}]^{+}$259.1441; found 259.1445. Regiochemistry was assigned after observing a correlation (HMBC experiment) between the hemiaminal methine proton $(6.72 \mathrm{ppm})$ and the $\mathrm{C}_{5}$-carbon of the imidazole $(112.4 \mathrm{ppm}) . \quad$ Enantiomeric ratio (er) determination (Lux Amylose-2 column; eluent B: methanol + 0.2\% ammonia): 92:8.
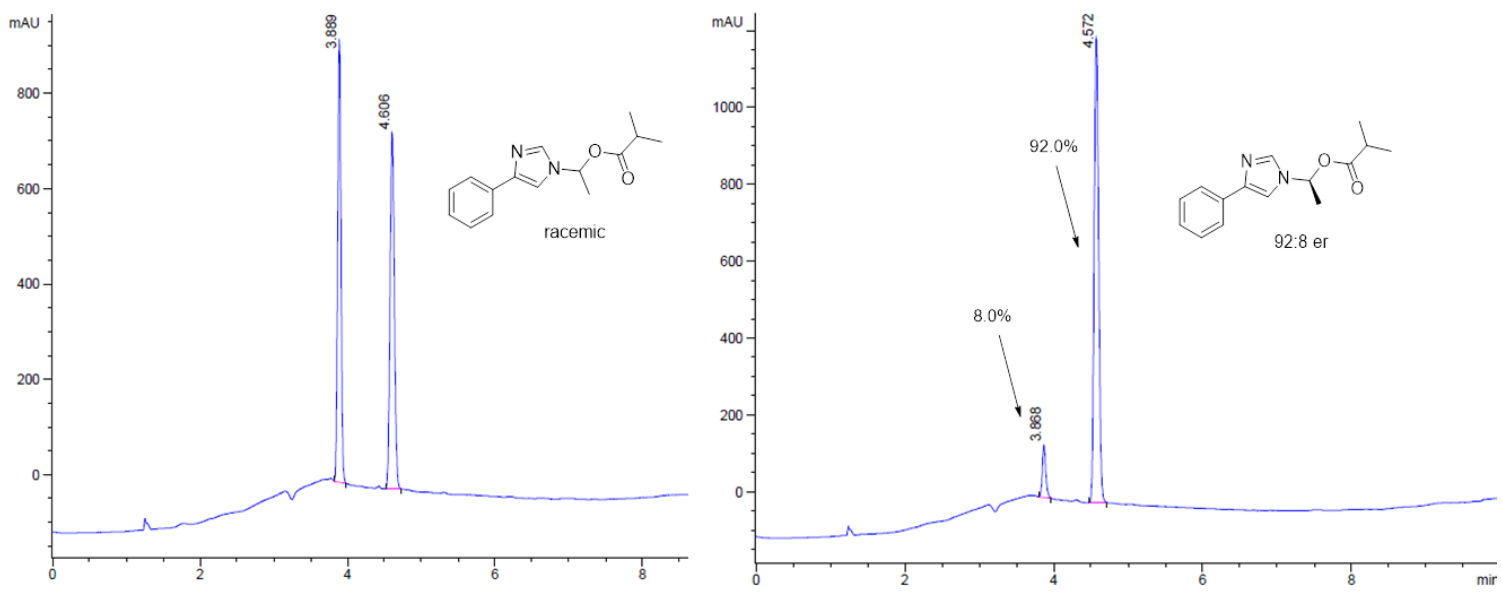

\section{Attempted catalytic enantioselective synthesis of sulfonate esters}

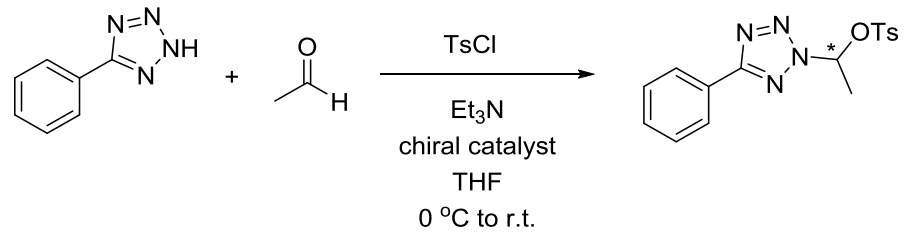

A round-bottom flask was charged with 5-phenyl- $1 H$-tetrazole (100 mg, $0.684 \mathrm{mmol}, 1.05$ equiv), THF (1.85 mL), acetaldehyde ( $0.17 \mathrm{~mL}, 3.3 \mathrm{mmol}, 5.0$ equiv), a chiral catalyst ( 0.04 equiv), and triethylamine $\left(0.10 \mathrm{~mL}, 0.72 \mathrm{mmol}, 1.1\right.$ equiv). The reaction was cooled to $0{ }^{\circ} \mathrm{C}$, and tosyl chloride (124 mg, $0.651 \mathrm{mmol}, 1.00$ equiv) dissolved in THF ( $3 \mathrm{~mL})$ was added dropwise at the rate of $(0.12 \mathrm{~mL} / \mathrm{min})$. The reaction was maintained at $0{ }^{\circ} \mathrm{C}$ for $3 \mathrm{~h}$, and then warmed to $25{ }^{\circ} \mathrm{C}$ for $16 \mathrm{~h}$. The reaction mixtures was concentrated in vacuo, and purified via column chromatography to provide the product which was analyzed by chiral HPLC.

Chiral catalysts screened include:

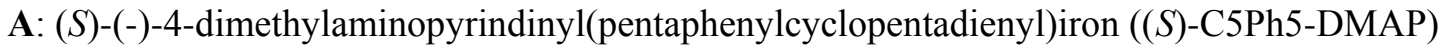

B: $(S)$-(-)-4-pyrrolidinopyrindinyl(pentamethylcyclopentadienyl)iron ((S)-PPY) 
E: ((2S)-2-(bis(3,5-bis(trifluoromethyl)phenyl)hydroxymethyl)-1-pyrrolidinyl)(4-(1-pyrrolidinyl)3-pyridinyl)methanone

G: (R)-(4-(dimethylamino)pyridin-3-yl)(4-isopropyl-2-thioxothiazolidin-3-yl)methanone

H: (R)-2-phenyl-2,3-dihydrobenzo[d]imidazo[2,1-b]thiazole

Yield (\%) / e.r.

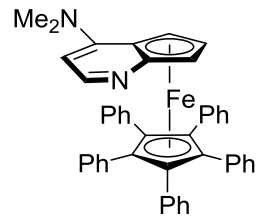

A: $(S)-\mathrm{C}_{5} \mathrm{Ph}_{5}$-DMAP

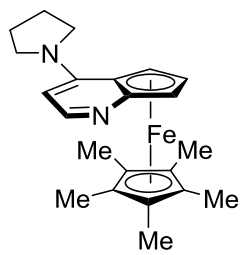

B: (S)-PPY

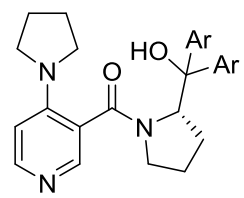

$\mathrm{E}: \mathrm{Ar}=3,5-\left(\mathrm{CF}_{3}\right)_{2}-\mathrm{C}_{6} \mathrm{H}_{3}$
$46 / 0$<smiles>CC(C)[C@H]1CSC(=S)N1C(=O)c1cnccc1N(C)C</smiles>

G<smiles>c1ccc(C2CN3C(=N2)Sc2ccccc23)cc1</smiles>

H
Yield (\%) / e.r.

$32 / 0$

$52 / 0$

\section{Formation of sulfonate ester 10 using stoichiometric chiral catalyst}

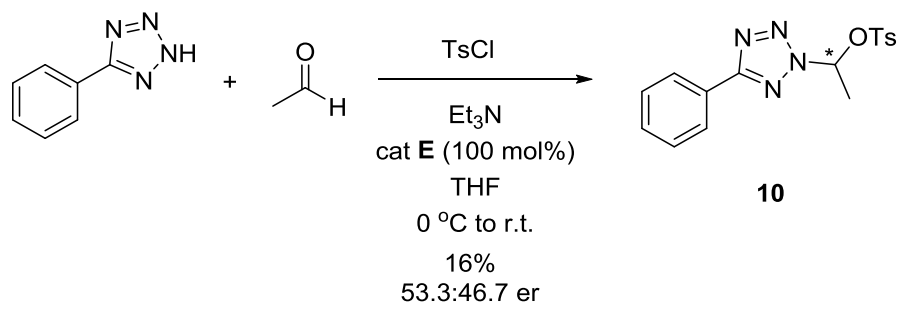

A vial was charged with $\{(2 S)-2-\{$ bis[3,5-bis(trifluoromethyl)phenyl]hydroxymethyl $\}-1$ pyrrolidinyl\} [4-(1-pyrrolidinyl)-3-pyridinyl]methanone (chiral DMAP catalyst E) (461 mg, 100 mol\%, $0.659 \mathrm{mmol})$, THF (3.2 mL) and tosyl chloride (127 mg, $0.666 \mathrm{mmol}, 1.01$ equiv). The solution was stirred for $15 \mathrm{~min}$ then cooled to $0{ }^{\circ} \mathrm{C}$. A solution of 5-phenyl- $1 \mathrm{H}$-tetrazole $(96.3$ $\mathrm{mg}, 0.659 \mathrm{mmol}, 1.00$ equiv), acetaldehyde (45.3 $\mu \mathrm{L}, 0.725 \mathrm{mmol}, 1.10$ equiv) and trimethylamine $(101 \mu \mathrm{L}, 0.725 \mathrm{mmol}, 1.10$ equiv) in THF $(4.0 \mathrm{~mL})$ was added and the reaction mixture was warmed to room temperature and stirred overnight. The reaction mixture was diluted with EtOAc and $0.2 \mathrm{~N} \mathrm{HCl} /$ brine and extracted $3 \mathrm{x}$ with EtOAc. The combined organic layers were dried over $\mathrm{MgSO}_{4}$, concentrated in vacuo, and the residue was purified by silica gel 
chromatography (gradient of 0-20\% EtOAc in heptane (v/v)) to afford $36.2 \mathrm{mg}$ (16\% yield) of the product 10.

See above for full characterization.

Enantiomeric ratio (er) determination (Lux Amylose-1 column, EtOH in place of $\mathrm{MeOH}$ ): $53.3: 46.7$

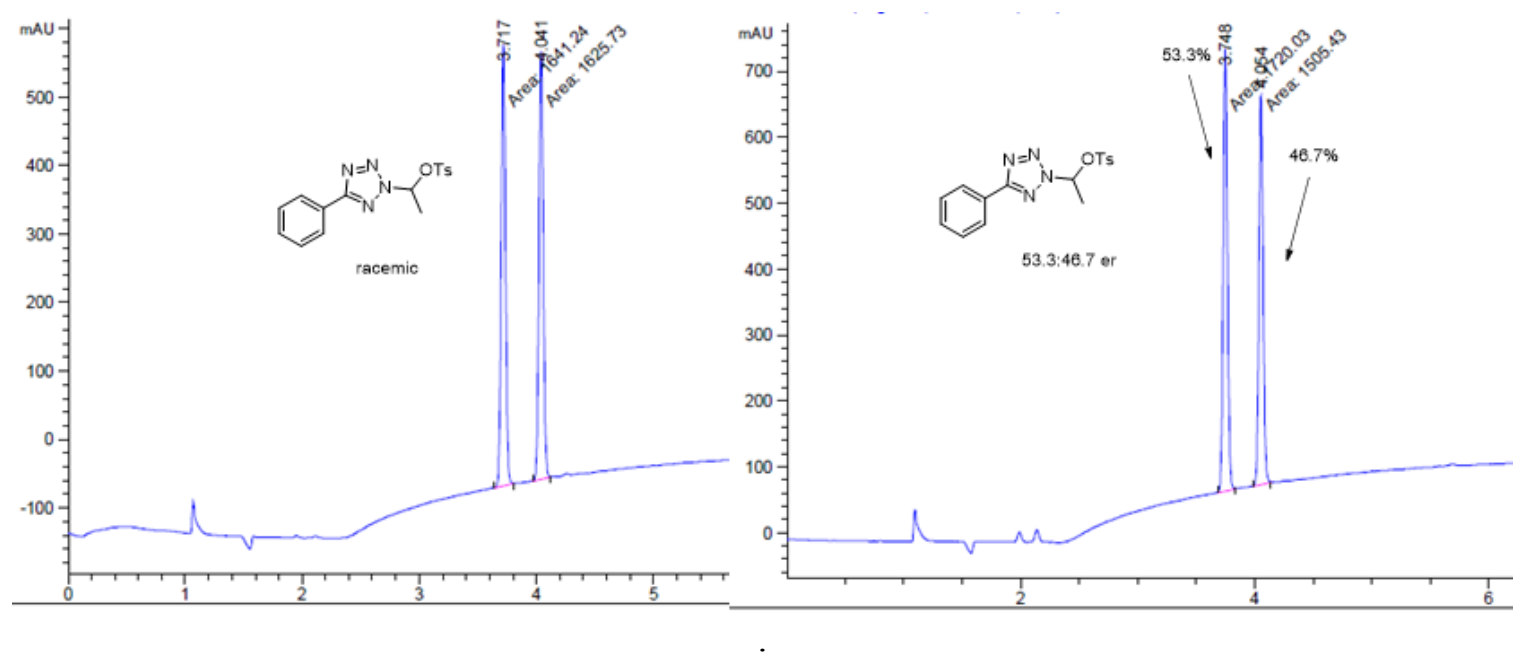

\section{Synthesis of $32^{2}$}

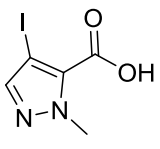

30

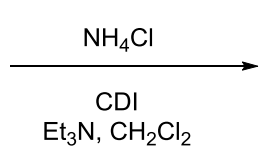

$75 \%$

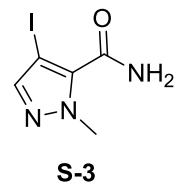

S-3

A round-bottom flask was charged with 4-iodo-1-methyl-1H-pyrazole-5-carboxylic acid (30) (297 g, 1.18 mol, 1.00 equiv), $\mathrm{CH}_{2} \mathrm{Cl}_{2}$ (2.97 L), and 1,1'-carbonyldiimidazole (CDI) (207 g, 97\% by mass, $1.24 \mathrm{~mol}, 1.05$ equiv). The reaction mixture was stirred at room temperature for $45 \mathrm{~min}$. Ammonium chloride (189 g, $3.53 \mathrm{~mol})$ and triethylamine $(498 \mathrm{~mL}, 3.53 \mathrm{~mol}, 3.00$ equiv) were added and the reaction mixture was stirred at room temperature overnight. The reaction mixture was concentrated in vacuo and the residue was suspended in $\mathrm{H}_{2} \mathrm{O}(\sim 3 \mathrm{~L})$ and granulated at room temperature for $1 \mathrm{~h}$. The solid was collected via filtration, washed with $\mathrm{H}_{2} \mathrm{O}$, and dried in a vacuum oven to afford 4-iodo-1-methyl-1 $H$-pyrazole-5-carboxamide (S-3) as a colorless solid (222 g, 75\% yield).

NMR Spectroscopy: ${ }^{1} \mathrm{H}$ NMR (400 MHz, $\mathrm{CDCl}_{3}, 25{ }^{\circ} \mathrm{C}, \delta$ ): 7.53 (s, 1H), 6.56 (br s, 1H), 6.01 (br $\mathrm{s}, 1 \mathrm{H}), 4.21(\mathrm{~s}, 3 \mathrm{H})$. 


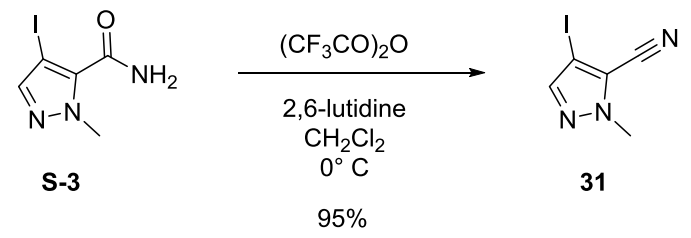

A round-bottom flask was charged with 4-iodo-1-methyl-1H-pyrazole-5-carboxamide (S-3) (222 g, $886 \mathrm{mmol}, 1.00$ equiv) and $\mathrm{CH}_{2} \mathrm{Cl}_{2}(2.22 \mathrm{~L})$ and the reaction mixture was cooled to $0{ }^{\circ} \mathrm{C}$. 2,6Lutidine $(310 \mathrm{~mL}, 2.66 \mathrm{~mol}, 3.00$ equiv) and trifluoroacetic anhydride $(253 \mathrm{~mL}, 1.77 \mathrm{~mol}, 2.00$ equiv) were added. After reaction was complete, saturated aqueous sodium bicarbonate $(800 \mathrm{~mL})$ was added and the layers separated. The aqueous layer was washed with $\mathrm{CH}_{2} \mathrm{Cl}_{2}(800 \mathrm{~mL})$. The organic layers were combined and washed with saturated aqueous ammonium chloride $(800 \mathrm{~mL})$, $1 \mathrm{~N} \mathrm{HCl}(800 \mathrm{~mL})$, and brine $(800 \mathrm{~mL})$. The organic layer was dried over magnesium sulfate, filtered, and concentrated in vacuo. The residue was suspended in heptanes ( $2 \mathrm{~L})$ and granulated at $0-5{ }^{\circ} \mathrm{C}$ for $30 \mathrm{~min}$. The solid was collected via filtration and dried in a vacuum oven to afford 4-iodo-1-methyl-1 $H$-pyrazole-5-carbonitrile (31) as a colorless solid (196 g, 95\% yield).

NMR Spectroscopy: ${ }^{1} \mathrm{H}$ NMR (400 MHz, $\left.\mathrm{CDCl}_{3}, 25^{\circ} \mathrm{C}, \delta\right): 7.60$ (s, $\left.1 \mathrm{H}\right), 4.09$ (s, 3H).

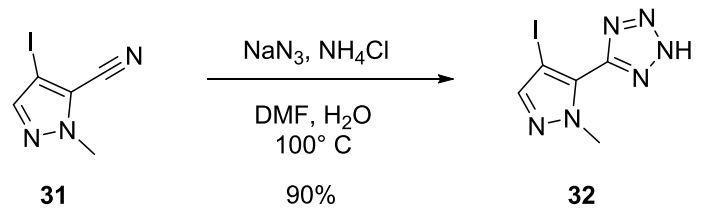

Caution: This reaction generates hydrazoic acid and requires extreme safety measures.

A reaction vessel was charged with DMF (1.225 L), 4-iodo-1-methyl-1 $H$-pyrazole-5-carbonitrile (31) (175 g, $751 \mathrm{mmol}, 1.00$ equiv), sodium azide (147 g, $2.25 \mathrm{~mol}, 3.00$ equiv), and ammonium chloride (121 g, $2.25 \mathrm{~mol}, 3.00$ equiv). $\mathrm{H}_{2} \mathrm{O}(525 \mathrm{~mL})$ was added slowly to minimize exotherm. The reaction mixture was heated at $100{ }^{\circ} \mathrm{C}$ overnight. The reaction mixture was cooled to room temperature and poured into a mixture of $\mathrm{H}_{2} \mathrm{O}(2 \mathrm{~L})$ and ice $(1 \mathrm{~kg})$. An aqueous solution of $\mathrm{NaNO}_{2}(600 \mathrm{~mL}, 120 \mathrm{~g} \mathrm{NaNO} 2,20 \%$ by weight) was added followed by the slow addition of aqueous $\mathrm{H}_{2} \mathrm{SO}_{4}$ until the $\mathrm{pH}$ of the reaction mixture was 1 . The precipitate was collected via filtration, washed with $\mathrm{H}_{2} \mathrm{O}$ and dried in vacuo to afford 5-(4-iodo-1-methyl-1H-pyrazol-5-yl)$2 \mathrm{H}$-tetrazole (32) as a colorless solid (187 g, 90\%).

NMR Spectroscopy: ${ }^{1} \mathrm{H}$ NMR (400 MHz, $\left.\mathrm{CD}_{3} \mathrm{OD}, 25{ }^{\circ} \mathrm{C}, \delta\right): 7.69$ (s, 1H), 4.08 (s, 3H).

Note: The preparation of $\mathbf{3 2}$ has been carried out on a kilogram scale. 


\section{DKR on kilogram scale for synthesis of $\mathbf{3 3}$}

(S)-1-(5-(4-Iodo-1-methyl-1H-pyrazol-5-yl)-2H-tetrazol-2-yl)ethyl isobutyrate (Scheme 3, 33)
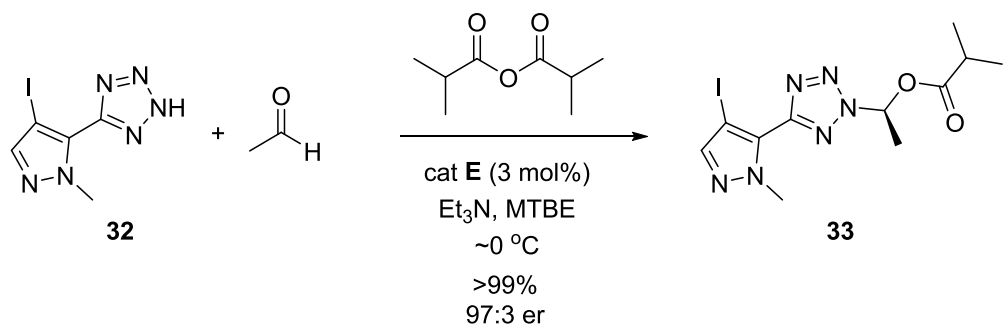

A reactor purged with nitrogen was charged with MTBE (125 L), 5-(4-iodo-1-methyl-1Hpyrazol-5-yl)-2 $H$-tetrazole (32) $(2.50 \mathrm{~kg}, 9.06 \mathrm{~mol}, 1.00$ equiv), catalyst $\mathbf{E}$ (188 g, $0.269 \mathrm{~mol}, 3$ mol\%). The reactor was cooled to $2{ }^{\circ} \mathrm{C}$. While maintaining an internal temperature of $-5-5{ }^{\circ} \mathrm{C}$, acetaldehyde (0.808 kg, 18.3 mol, 2.02 equiv) was added followed by $\mathrm{Et}_{3} \mathrm{~N}$ (1.37 kg, $13.5 \mathrm{~mol}$, 1.49 equiv), and lastly isobutyric anhydride $(2.15 \mathrm{~kg}, 13.6 \mathrm{~mol}, 1.50$ equiv). The internal temperature was held between $-5-5{ }^{\circ} \mathrm{C}$ for $14 \mathrm{~h}$, at which point a sample indicated $>99 \%$ conversion to product. The reaction mixture was concentrated in vacuo to approximately $38 \mathrm{~L}$. The temperature was adjusted to $16^{\circ} \mathrm{C}$. While maintaining an internal temperature of $15-30{ }^{\circ} \mathrm{C}$, $\mathrm{H}_{2} \mathrm{O}(25 \mathrm{~L})$ was added, and the reaction mixture was agitated for $30 \mathrm{~min}$. The layers were allowed to separate and the aqueous layer removed. The organic layer was concentrated in vacuo to approximately $15 \mathrm{~L}$. Three times, $\mathrm{MeOH}(50 \mathrm{~L})$ was added to the reaction mixture and then concentrated in vacuo to approximately $15 \mathrm{~L}$ to afford the title compound (33) as a solution in $\mathrm{MeOH}$ for further processing.

$\mathrm{R}_{f}=0.29$ (heptane/EtOAc 4:1 (v/v)). NMR Spectroscopy: ${ }^{1} \mathrm{H}$ NMR $\left(400 \mathrm{MHz}, \mathrm{CDCl}_{3}, 25{ }^{\circ} \mathrm{C}, \delta\right)$ : 7.62 (s, 1H), 7.38 (q, J=6.2 Hz, 1H), 4.22 (s, 3H), 2.62 (qq, $J=7.0,7.0 \mathrm{~Hz}, 1 \mathrm{H}), 2.04$ (d, $J=6.2 \mathrm{~Hz}$, $3 \mathrm{H}), 1.20(\mathrm{~d}, J=6.8 \mathrm{~Hz}, 3 \mathrm{H}), 1.17(\mathrm{~d}, J=6.8 \mathrm{~Hz}, 3 \mathrm{H}) .{ }^{13} \mathrm{C}$ NMR $\left(101 \mathrm{MHz}, \mathrm{CDCl}_{3}, 25{ }^{\circ} \mathrm{C}, \delta\right)$ : 174.9, 156.7, 145.3, 131.6, 80.4, 60.8, 40.4, 33.8, 19.5, 18.8, 18.7. IR (thin film, $\mathrm{cm}^{-1}$ ): 1754, 1328, 1184, 1085, 992, 957, 845, 755. HRMS (m/z): calculated for $\mathrm{C}_{11} \mathrm{H}_{16} \mathrm{IN}_{6} \mathrm{O}_{2}[\mathrm{M}+\mathrm{H}]^{+}$ 391.0374; found 391.0370. Enantiomeric ratio (er) determination (Lux Amylose-2 column; eluent B: methanol/acetonitrile 1:1): 97:3. 

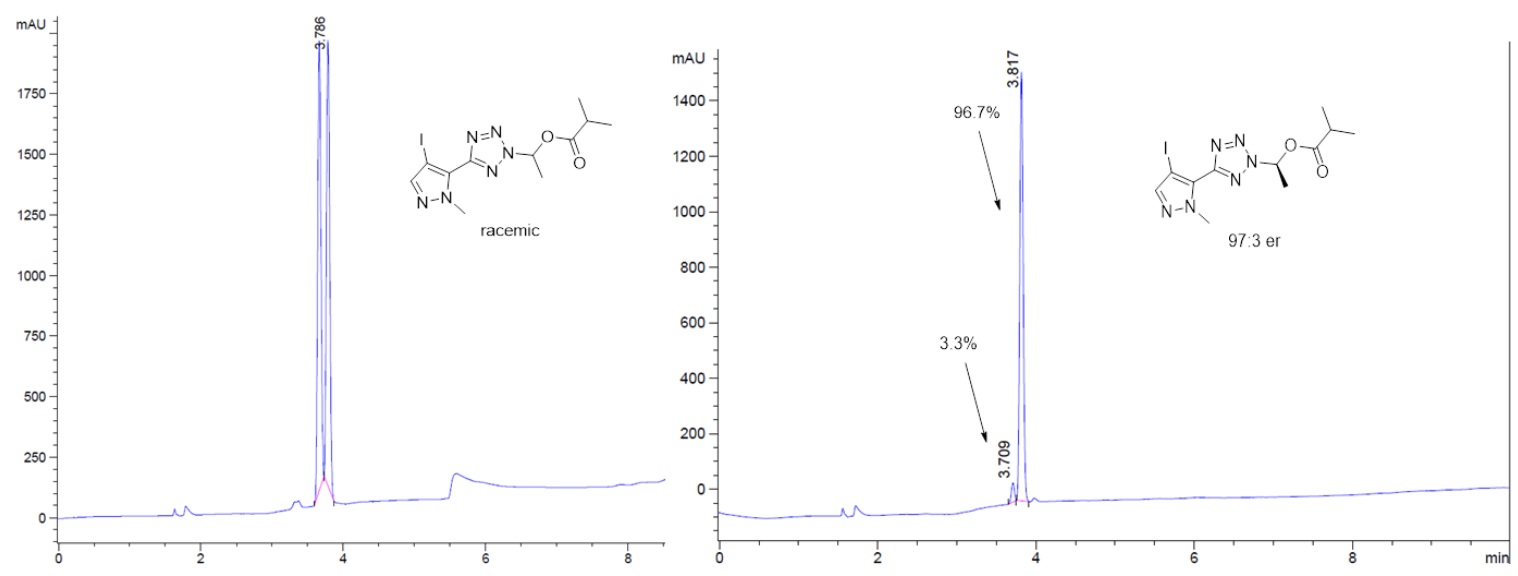

\section{Completion of the synthesis of tetrazole prodrug 35}

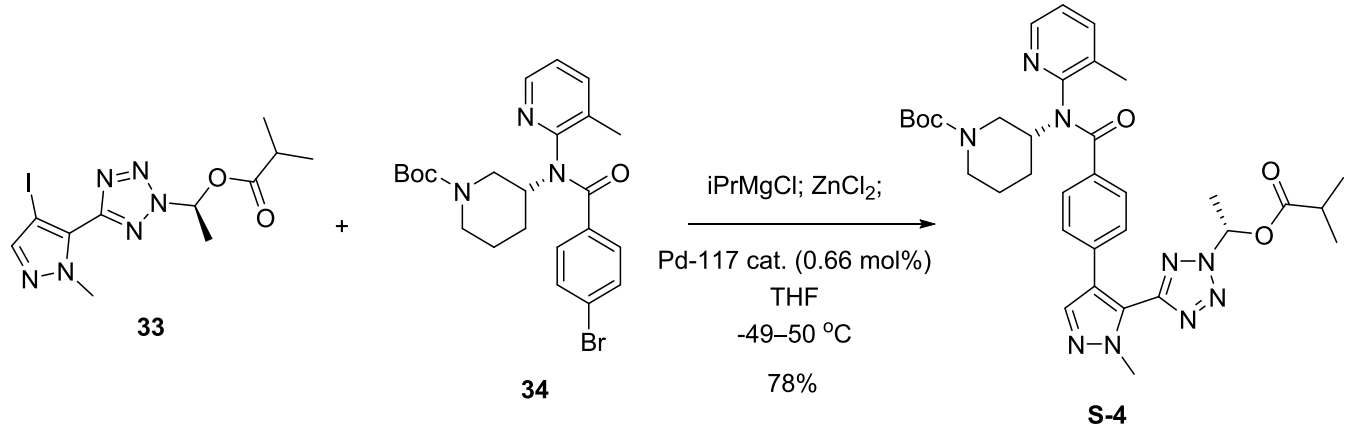

A 5L, 4-necked round-bottom flask was charged with (S)-1-(5-(4-iodo-1-methyl-1H-pyrazol-5yl)-2H-tetrazol-2-yl)ethyl isobutyrate (33) (192 g, $487 \mathrm{mmol}, 1.00$ equiv), and THF (2 L). The solution was cooled to $-49^{\circ} \mathrm{C}$. A solution of isopropylmagnesium chloride $(2.0 \mathrm{~mol} / \mathrm{L})$ in THF (305 mL, $610 \mathrm{mmol}, 1.30$ equiv) was added over the course of $26 \mathrm{~min}$. The internal temperature did not rise above $-41{ }^{\circ} \mathrm{C}$. The reaction mixture was held at -45 to $-42{ }^{\circ} \mathrm{C}$ for $10 \mathrm{~min}$. A solution of zinc chloride ( $1.9 \mathrm{~mol} / \mathrm{L})$ in 2-methylTHF $(175 \mathrm{~mL}, 330 \mathrm{mmol}, 0.678$ equiv) was added over the course of $10 \mathrm{~min}$. The internal temperature did not rise above $33{ }^{\circ} \mathrm{C}$. The reaction mixture became opaque yellow. The reaction mixture was warmed $25{ }^{\circ} \mathrm{C}$ over 50 min to give a clear yellow solution. Solid tert-butyl (3R)-3-[(4-bromobenzoyl)(3-methylpyridin-2yl)amino]piperidine-1-carboxylate (34) (230 g, $485 \mathrm{mmol}, 0.995$ equiv) was added. The reaction mixture was warmed to 31 ${ }^{\circ} \mathrm{C}$ and then dichloro[bis(diphenylphosphinophenyl)ether]palladium(II) (Pd-117) (2.44 g, 3.24 mmol, 0.00664 equiv) was added. The reaction mixture was heated between 45 and $50{ }^{\circ} \mathrm{C}$ for $25 \mathrm{~min}$. The reaction mixture was cooled and quenched with addition of half-saturated aqueous ammonium chloride solution $(1 \mathrm{~L})$. The layers were filtered through Celite and separated. The organic layer was concentrated in vacuo, dissolved in $\mathrm{CH}_{2} \mathrm{Cl}_{2}(1 \mathrm{~L})$ and filtered through Celite again. The solution was concentrated in vacuo and the residue was purified by silica gel chromatography (gradient of 50-70\% EtOAc in heptane (v/v)) to afford $250 \mathrm{~g}$ (78\% yield) of tert-butyl (R)-3-(4(5-(2-((S)-1-(isobutyryloxy)ethyl)-2H-tetrazol-5-yl)-1-methyl-1H-pyrazol-4-yl)- $N$-(3- 
methylpyridin-2-yl)benzamido)piperidine-1-carboxylate (S-4).

NMR Spectroscopy: ${ }^{1} \mathrm{H}$ NMR (400 MHz, $\mathrm{CDCl}_{3}, 25^{\circ} \mathrm{C}, \delta$ ): 8.40 (br s, 1H), 7.60 (s, 1H), 7.34 (br s, 1H), 7.30 (q, 1H), 7.23 (br s, 2H), 7.17-7.07 (br m, 3H), 4.48 (br d, 1H), 4.15-3.95 (br m, 4H), 3.42 (br s, 1H), 2.63-2.50 (m, 2H), 2.39 (br s, 1H), 2.05-1.93 (br m, 6H), 1.76-1.62 (br m, 4H), 1.50-1.42 (br m, 9H), 1.19 (d, 3H), 1.14 (d, 3H).

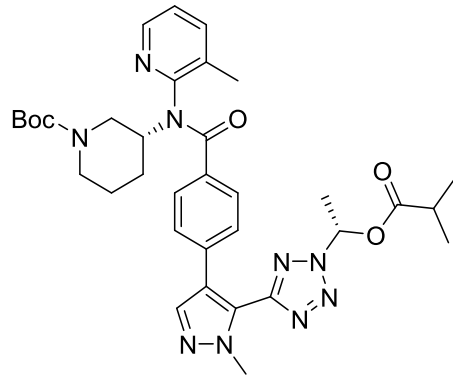

S-4

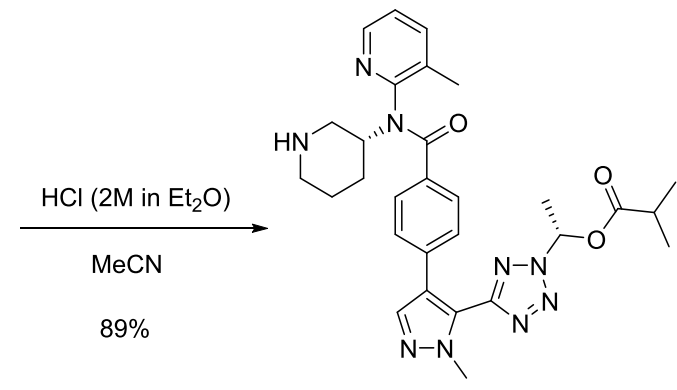

35

A 5L round-bottom flask was charged with tert-butyl $(R)-3-(4-(5-(2-((S)-1-($ isobutyryloxy)ethyl)2H-tetrazol-5-yl)-1-methyl-1 $H$-pyrazol-4-yl)- $N$-(3-methylpyridin-2-yl)benzamido)piperidine-1carboxylate (S-4) (276 g, $428 \mathrm{mmol}, 1.00$ equiv) and $\mathrm{MeCN}$ (2.76 L). Hydrochloric acid (2 $\mathrm{mol} / \mathrm{L})$ in diethyl ether (1.5 L, $3.0 \mathrm{~mol}, 7.0$ equiv) was added over $20 \mathrm{~min}$. The reaction mixture was stirred at room temperature for $1.5 \mathrm{~h}$. The reaction mixture was concentrated in vacuo to a volume of $1.1 \mathrm{~L}$, diluted with MTBE $(2.76 \mathrm{~L})$, and granulated for $1 \mathrm{~h}$. The solid was collected via filtration and dried to afford $241 \mathrm{~g}$ (89\% yield) of the bis $\mathrm{HCl}$ salt of 35 ((S)-1-(5-(1-methyl-4-(4((3-methylpyridin-2-yl)((R)-piperidin-3-yl)carbamoyl)phenyl)- $1 H$-pyrazol-5-yl)-2H-tetrazol-2yl)ethyl isobutyrate (35).

NMR Spectroscopy: ${ }^{1} \mathrm{H}$ NMR (400 MHz, $\mathrm{CDCl}_{3}, 25{ }^{\circ} \mathrm{C}, \delta$ ): 9.75 (br s, $1 \mathrm{H}$ ), 9.31 (br s, $1 \mathrm{H}$ ), 8.47 (s, 1H), 7.98 (br s, 1H), 7.68 (s, 1H), 7.60 (br s, 1H), 7.38-7.32 (m, 3H), 7.24-7.20 (br m, 2H), 5.05 (br s, 1H), 3.99 (s, 3H), 3.87 (br s, 1H), 3.68 (br s, 1H), 3.33 (br s, 1H), 2.88 (br s, 1H), 2.64-2.59 (m, 1H), 2.26 (br s, 4H), 2.07-2.01 (m, 1H), 1.94-1.86 (m, 4H), 1.60 (br s, 1H), 1.17 $(\mathrm{d}, 3 \mathrm{H}), 1.10(\mathrm{~d}, 3 \mathrm{H})$. 


\section{Kinetic Data}

Equilibrium data for 5-phenyl- $1 H$-tetrazole and acetaldehyde: ${ }^{1} \mathrm{H}$ NMR

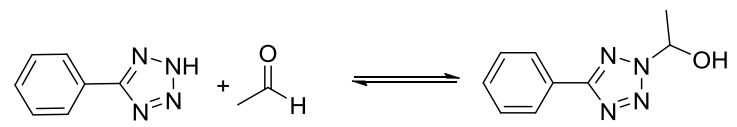

A solution of 5-phenyl- $1 H$-tetrazole $(5 \mathrm{mM})$ and acetaldehyde $(100 \mathrm{mM})$ in $\mathrm{CD}_{3} \mathrm{CN}$ was analyzed by NMR for the formation of an adduct at various temperatures. Only the 2,5-disubstituted tetrazole-aldehyde adduct was observed. The yield was temperature dependent. From variable temperature NMR experiments, kinetic parameters, $\Delta G^{0}, \Delta H^{0}$ and $\Delta S^{0}$, of this reaction were determined (Figures S2).

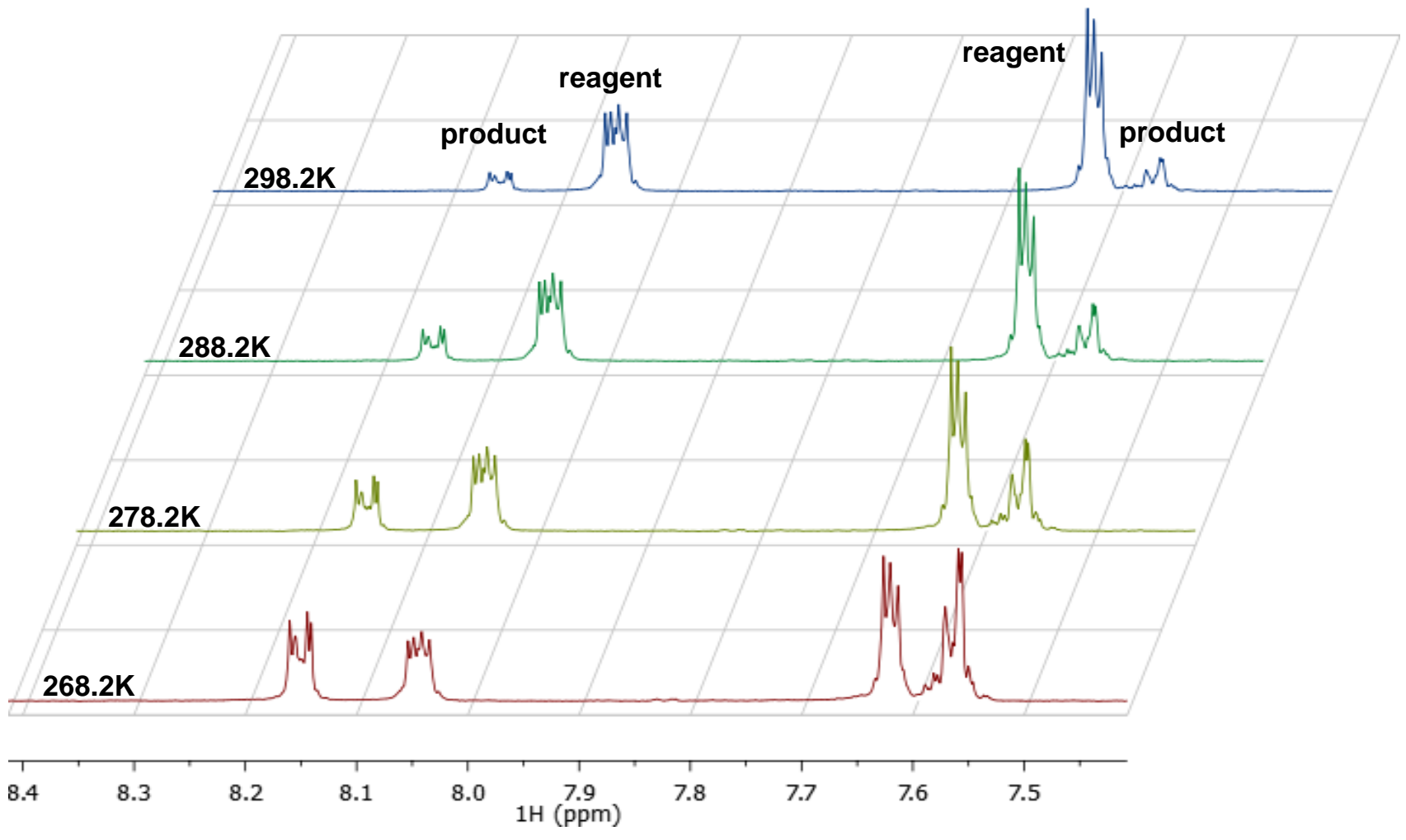

Figure S1: ${ }^{1} \mathrm{H}$ NMR spectra of $5 \mathrm{mM}$ 5-phenyl-1H-tetrazole and $100 \mathrm{mM}$ acetaldehyde in $\mathrm{CD}_{3} \mathrm{CN}$ at various temperatures $(\mathrm{K})$. 


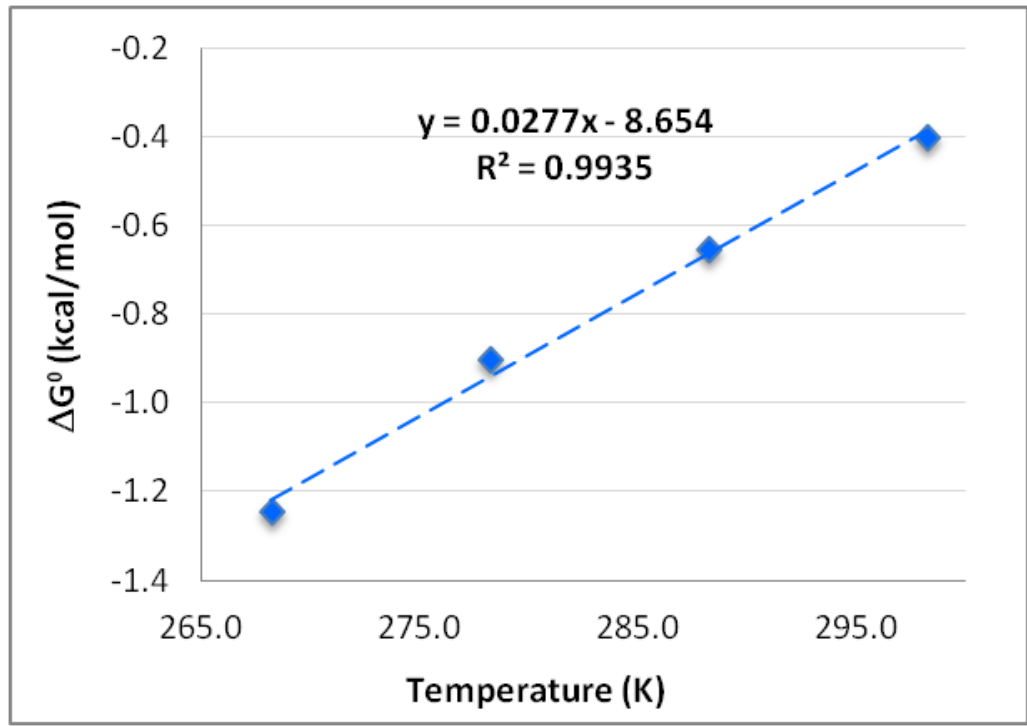

$$
\begin{gathered}
\Delta G^{0}=\Delta H^{0}-T \Delta S^{0} \\
\Delta H^{0}=-8.7 \mathrm{kcal} / \mathrm{mol} \\
\Delta S^{0}=-28 \mathrm{cal} /(\mathrm{mol} \cdot \mathrm{K})
\end{gathered}
$$

Figure S2: Kinetic data of 5-phenyl-1H-tetrazole and acetaldehyde in $\mathrm{CD}_{3} \mathrm{CN}$ determined by ${ }^{1}$ H NMR.

Equilibrium data for 5-(4'-methyl-[1,1'-biphenyl]-2-yl)-2H-tetrazole (15) and isobutyraldehyde (Scheme 2)

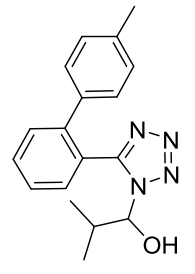

17, 1,5-isomer
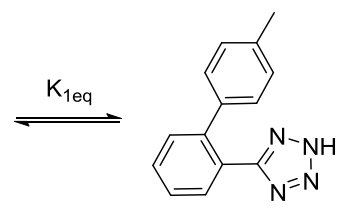

15
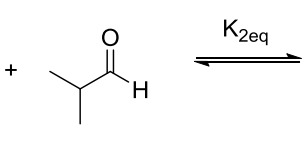
When 5-(4'-methyl-[1,1'-biphenyl]-2-yl)-2H-tetrazole $(15) \quad(5 \quad \mathrm{mM})$ was mixed with
isobutryaldehyde $(100 \mathrm{mM})$ in $\mathrm{CD}_{3} \mathrm{CN}$, both 2,5-disubstituted and 1,5-disubstituted tetrazoleWhen 5-(4'-methyl-[1,1'-biphenyl]-2-yl)-2H-tetrazole $(15) \quad(5 \quad \mathrm{mM})$ was mixed with
isobutryaldehyde $(100 \mathrm{mM})$ in $\mathrm{CD}_{3} \mathrm{CN}$, both 2,5-disubstituted and 1,5-disubstituted tetrazolealdehyde adducts (16 and 17) were observed, as shown in Figure S3. The yield of the 2,5-isomer was higher than that of 1,5-isomer and both increased when temperature dropped. With the known concentrations of starting materials, the concentration of each product was measured and the equilibrium constant $\left(K_{\text {eq }}\right)$ was also determined, as listed in Table S2. $K_{\text {eq }}$ of both reactions exponentially increased as temperature decreased. The difference of $\Delta G^{0}$ to form 2,5- and 1,5isomers was measured to be roughly $0.8 \mathrm{kcal} / \mathrm{mol}$ in the experimental temperature window from 258 to $308 \mathrm{~K}$. From a linear fit of $\Delta \mathrm{G}^{0}$ to temperature, $\Delta H^{0}$ and $\Delta S^{0}$ were also calculated. 

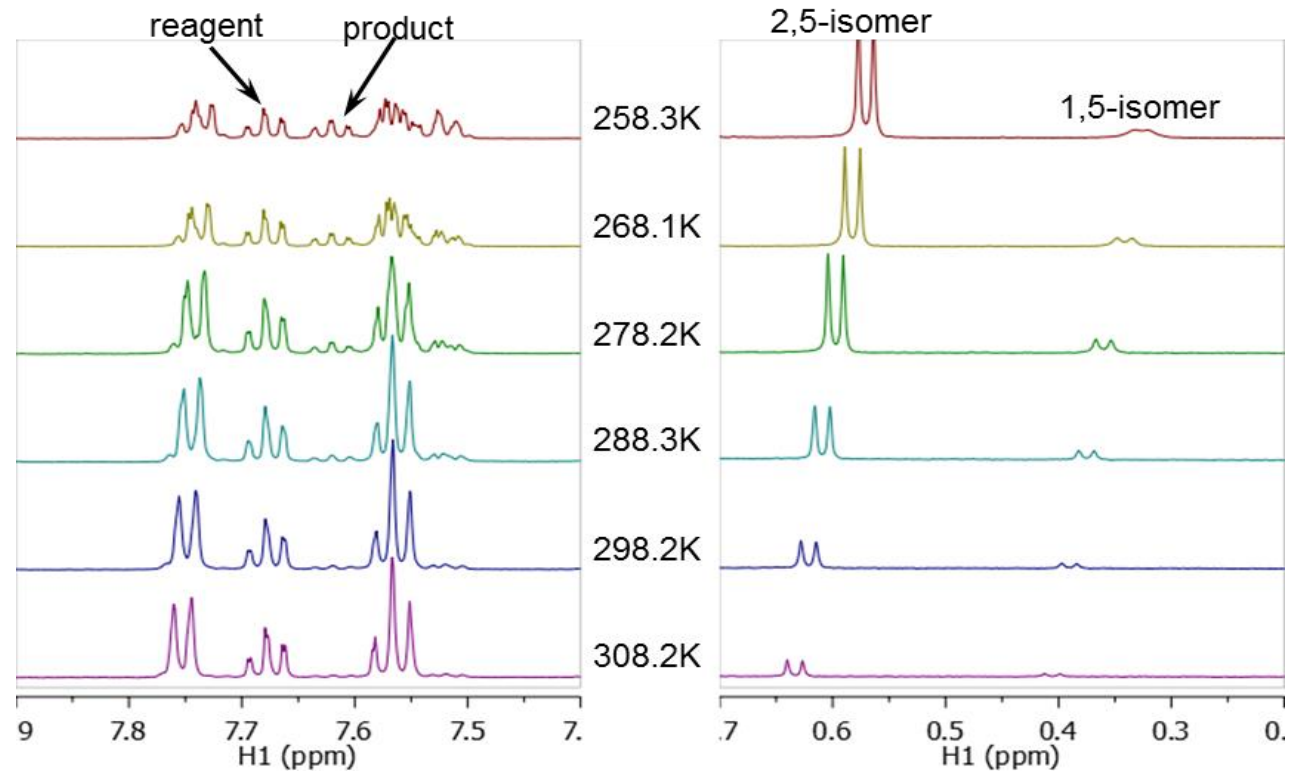

Figure S3: ${ }^{1} \mathrm{H}$ NMR spectra of $5 \mathrm{mM} \mathrm{5-(4'-methyl-[1,1'-biphenyl]-2-yl)-2H-tetrazole} \mathrm{(15)}$ and $100 \mathrm{mM}$ isobutryaldehyde in $\mathrm{CD}_{3} \mathrm{CN}$ at various temperatures (K).

\begin{tabular}{|c|c|c|c|c|c|c|c|}
\hline \multicolumn{2}{|c|}{ Temp (K) } & 258.3 & 268.1 & 278.2 & 288.3 & 298.2 & 308.2 \\
\hline \multirow{4}{*}{ Con. (mM) } & 1,5-isomer (17) & 0.36 & 0.27 & 0.16 & 0.10 & 0.06 & 0.04 \\
\hline & 2,5-isomer (16) & 1.79 & 1.07 & 0.65 & 0.43 & 0.27 & 0.18 \\
\hline & tetrazole (15) & 2.85 & 3.67 & 4.19 & 4.47 & 4.67 & 4.78 \\
\hline & isobutyraldehyde & 56.92 & 73.31 & 83.88 & 89.46 & 93.45 & 95.63 \\
\hline \multirow{2}{*}{$K_{\text {eq }}$} & 1,5-isomer (17) & 2.22 & 0.99 & 0.45 & 0.24 & 0.14 & 0.09 \\
\hline & 2,5-isomer (16) & 11.07 & 3.98 & 1.84 & 1.07 & 0.61 & 0.39 \\
\hline \multirow{3}{*}{$\begin{array}{c}\Delta \mathbf{G}^{0} \\
\mathrm{Kcal} / \mathrm{mol}\end{array}$} & 1,5-isomer (17) & -0.41 & 0.01 & 0.44 & 0.81 & 1.17 & 1.46 \\
\hline & 2,5 isomer (16) & -1.23 & -0.74 & -0.34 & -0.04 & 0.29 & 0.58 \\
\hline & $\Delta \mathrm{G}_{1}^{0}-\Delta \mathrm{G}_{2}^{0}$ & 0.82 & 0.74 & 0.78 & 0.85 & 0.88 & 0.88 \\
\hline
\end{tabular}

Table S2: NMR data observed for reaction of 5-(4'-methyl-[1,1'-biphenyl]-2-yl)-2H-tetrazole (15) and isobutryaldehyde in $\mathrm{CD}_{3} \mathrm{CN}$ 


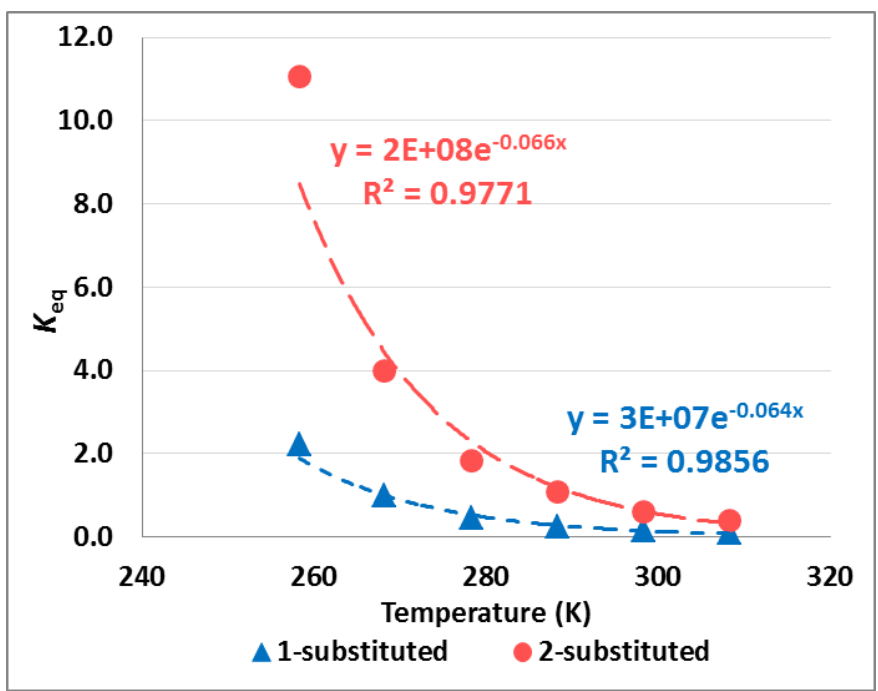

Figure S4: The exponential relationship of $K_{\text {eq }}$ to the temperature for the reaction of 5-(4'methyl-[1,1'-biphenyl]-2-yl)-2H-tetrazole (15) and isobutryaldehyde in $\mathrm{CD}_{3} \mathrm{CN}$. 


\section{X-ray crystal structure of ethyl (1-(5-phenyl-1 $H$-tetrazol-1-yl)ethyl) carbonate (2b, CCDC 1445809)}

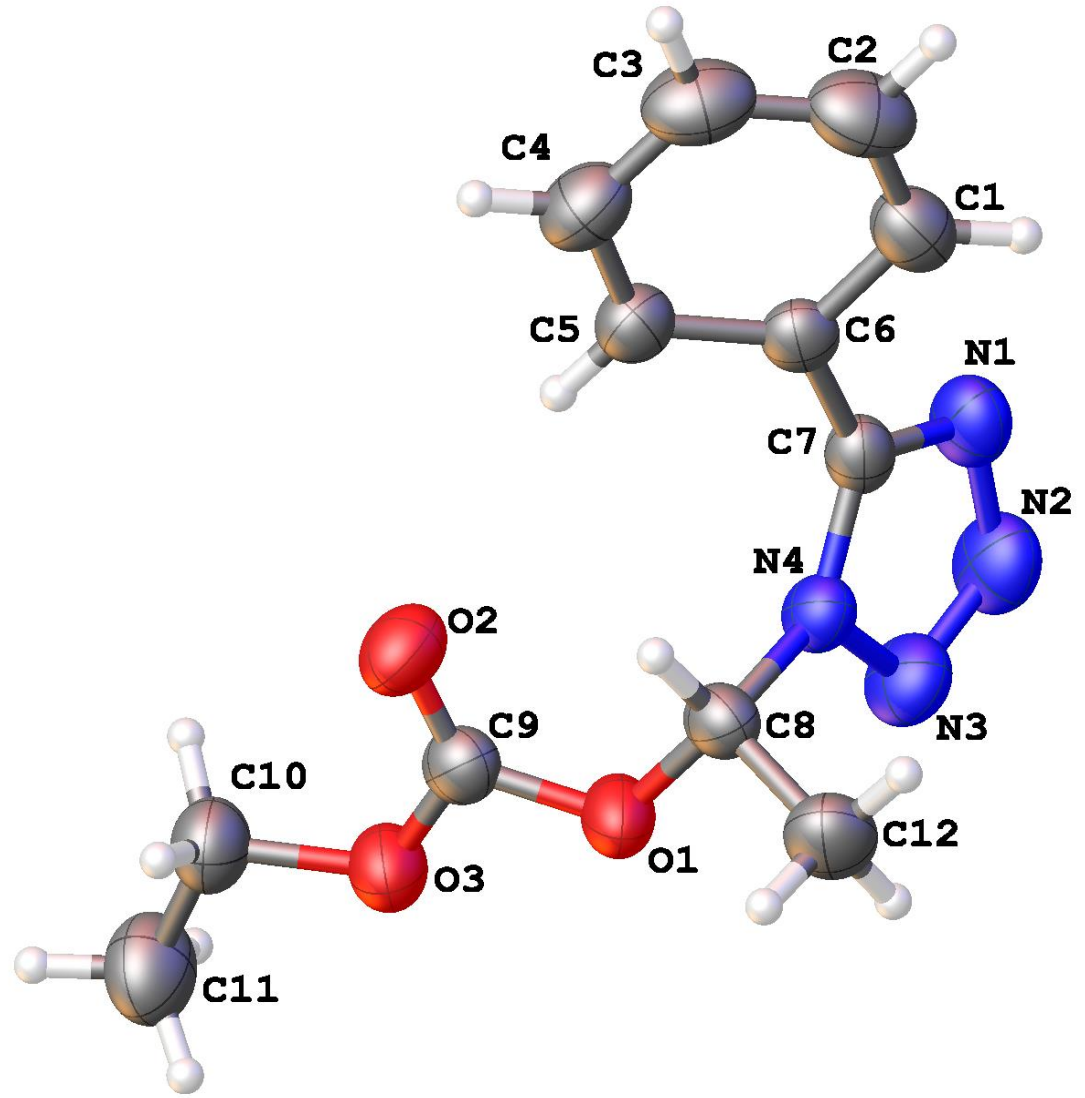

Figure S5. ORTEP drawing of ethyl (1-(5-phenyl-1 $H$-tetrazol-1-yl)ethyl) carbonate (2b)

Data collection was performed on a Bruker APEX diffractometer at room temperature. Data collection consisted of omega and phi scans. The structure was solved by direct methods using SHELX software suite in the space group P-1. The structure was subsequently refined by the full-matrix least squares method. All non-hydrogen atoms were found and refined using anisotropic displacement parameters. All hydrogen atoms were placed in calculated positions and were allowed to ride on their carrier atoms. The final refinement included isotropic displacement parameters for all hydrogen atoms. The final R-index was 3.9\%. A final difference Fourier revealed no missing or misplaced electron density.

Pertinent crystal, data collection and refinement are summarized in Table 1.

Table S3. Crystal data and structure refinement for ethyl (1-(5-phenyl-1H-tetrazol-1yl)ethyl) carbonate (2b)

Empirical formula

$\mathrm{C}_{12} \mathrm{H}_{14} \mathrm{~N}_{4} \mathrm{O}_{3}$ 
Formula weight

Temperature

Wavelength

Crystal system

Space group

Unit cell dimensions

Volume

Z

Density (calculated)

Absorption coefficient

$\mathrm{F}(000)$

Theta range for data collection

Index ranges

Reflections collected

Independent reflections

Completeness to theta $=70.20^{\circ}$

Absorption correction

Refinement method

Data / restraints / parameters

Goodness-of-fit on $\mathrm{F}^{2}$

Final R indices [I>2sigma(I)]

$\mathrm{R}$ indices (all data)

Largest diff. peak and hole
262.27

273(2) K

$1.54178 \AA$

Triclinic

P-1

$\mathrm{a}=7.9189(2) \AA \quad \alpha=86.5842(12)^{\circ}$.

$\mathrm{b}=8.9993(2) \AA \quad \beta=82.1820(11)^{\circ}$.

$\mathrm{c}=9.5359(3) \AA \quad \gamma=76.2332(11)^{\circ}$.

653.65(3) $\AA^{3}$

2

$1.333 \mathrm{Mg} / \mathrm{m}^{3}$

$0.824 \mathrm{~mm}^{-1}$

276

4.68 to $70.20^{\circ}$.

$-9<=\mathrm{h}<=9,-10<=\mathrm{k}<=10,-11<=\mathrm{l}<=11$

19289

$2430[\mathrm{R}(\mathrm{int})=0.0529]$

$97.8 \%$

Empirical

Full-matrix least-squares on $\mathrm{F}^{2}$

$2430 / 0 / 174$

0.965

$\mathrm{R} 1=0.0391, \mathrm{wR} 2=0.0972$

$\mathrm{R} 1=0.0463, \mathrm{wR} 2=0.1022$

0.220 and -0.137 e. $\AA^{-3}$ 


\section{X-ray crystal structure of $(S)-(3$ '-fluoro-4'-nitro-[1,1'-biphenyl]-4-yl)(5- phenyl-2H-tetrazol-2-yl)methyl isobutyrate (S-2, CCDC 1468821)}

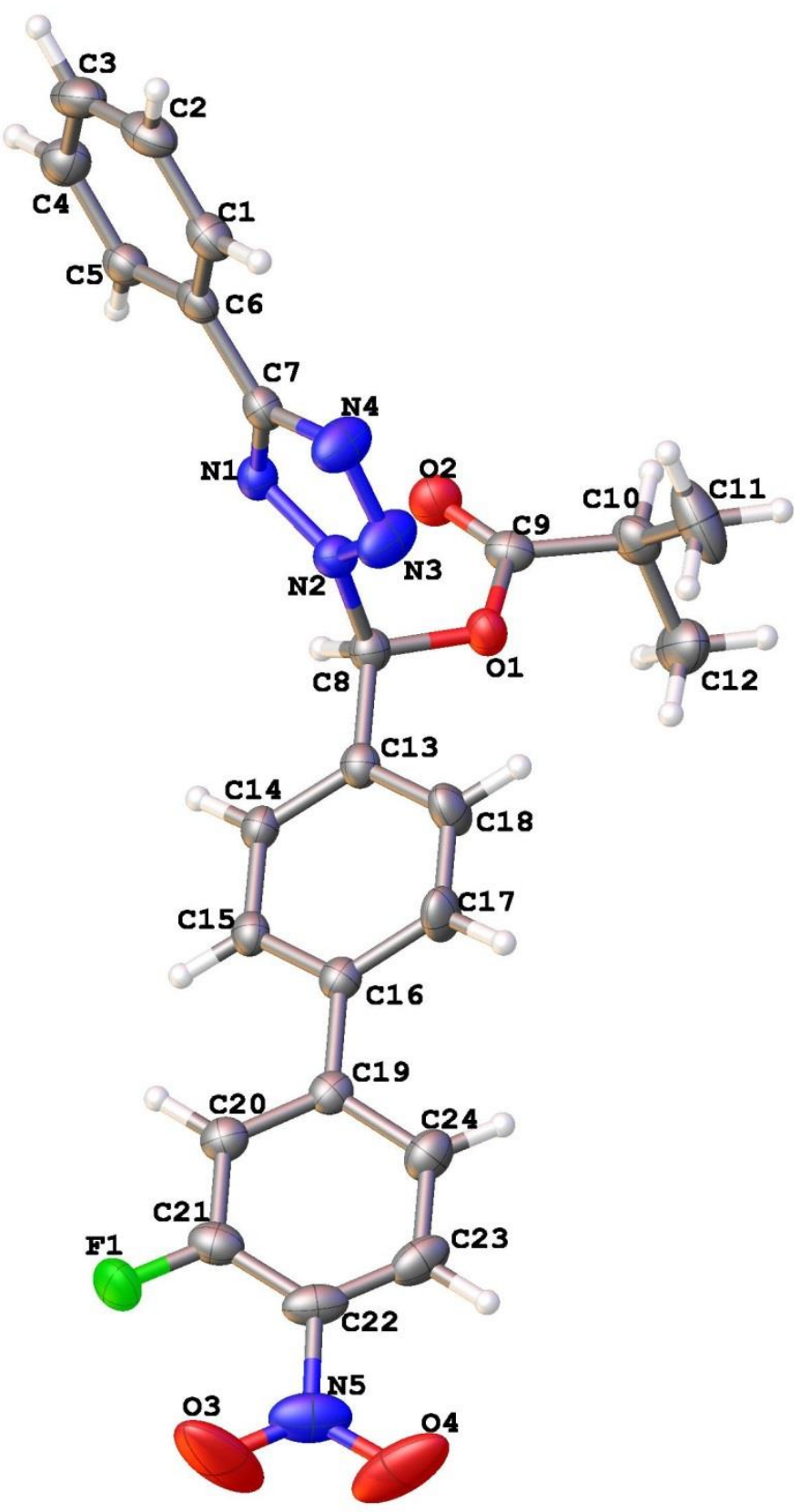

Figure S6. ORTEP drawing of $(S)$-(3'-fluoro-4'-nitro-[1,1'-biphenyl]-4-yl)(5-phenyl-2Htetrazol-2-yl)methyl isobutyrate (S-2)

Data collection was performed on a Bruker APEX diffractometer at $-150{ }^{\circ} \mathrm{C}$ temperature. Data collection consisted of omega and phi scans. The structure was solved by direct methods using SHELX software suite in the Trigonal class space group $\mathrm{P} 3{ }_{1} 21$. The structure was subsequently refined by the full-matrix least squares method. All non-hydrogen atoms were found and refined 
using anisotropic displacement parameters. The hydrogen atoms were placed in calculated positions and were allowed to ride on their carrier atoms. The final refinement included isotropic displacement parameters for all hydrogen atoms. Ring system (C19-C24-F1) disordered with two occupancies and modeled with $\sim 75$ to 25 population. Analysis of the absolute structure using likelihood methods was performed using PLATON. Assuming the sample submitted is enantiopure, the results indicate that the absolute structure has been correctly assigned. The method calculates that the probability that the structure is correctly assigned is 1.000 . The Hooft parameter is reported as -0.01 with an esd of 0.04 . The final R-index was $3.8 \%$. A final difference Fourier revealed no missing or misplaced electron density.

Pertinent crystal, data collection and refinement are summarized in Table S4.

Table S4. Crystal data and structure refinement for $(S)$-(3'-fluoro-4'-nitro-[1,1'-biphenyl]-4yl)(5-phenyl-2H-tetrazol-2-yl)methyl isobutyrate (S-2)

Empirical formula

Formula weight

Temperature

Wavelength

Crystal system

Space group

Unit cell dimensions

Volume

Z

Density (calculated)

Absorption coefficient

$\mathrm{F}(000)$

Crystal size

Theta range for data collection

Index ranges

Reflections collected

Independent reflections

Completeness to theta $=67.679^{\circ}$
$\mathrm{C}_{24} \mathrm{H}_{20} \mathrm{FN}_{5} \mathrm{O}_{4}$

461.45

123(2) K

$1.54178 \AA$

Trigonal

$\mathrm{P} 3{ }_{1} 21$

$\mathrm{a}=11.73880(10) \AA \quad \alpha=90^{\circ}$.

$\mathrm{b}=11.73880(10) \AA \quad \beta=90^{\circ}$.

$\mathrm{c}=27.4082(4) \AA \quad \gamma=120^{\circ}$.

$3270.83(7) \AA^{3}$

6

$1.406 \mathrm{Mg} / \mathrm{m}^{3}$

$0.871 \mathrm{~mm}^{-1}$

1440

$0.380 \times 0.180 \times 0.100 \mathrm{~mm}^{3}$

4.349 to $68.718^{\circ}$.

$-14<=\mathrm{h}<=14,-13<=\mathrm{k}<=14,-30<=1<=32$

33122

$3989[\mathrm{R}(\mathrm{int})=0.0289]$

$99.7 \%$ 
Absorption correction

Refinement method

Data / restraints / parameters

Goodness-of-fit on $\mathrm{F}^{2}$

Final $\mathrm{R}$ indices [I>2sigma(I)]

$\mathrm{R}$ indices (all data)

Absolute structure parameter

Extinction coefficient

Largest diff. peak and hole
None

Full-matrix least-squares on $\mathrm{F}^{2}$

3989 / 0 / 319

1.051

$\mathrm{R} 1=0.0382, \mathrm{wR} 2=0.0952$

$\mathrm{R} 1=0.0390, \mathrm{wR} 2=0.0961$

$0.00(4)$

$\mathrm{n} / \mathrm{a}$

0.495 and -0.353 e. $\AA^{-3}$

\section{X-ray crystal structure of $(S)$-ethyl 1-[5-(4-iodo-1-methyl-1H-pyrazol-5- yl)-2H-tetrazol-2-yl]ethyl carbonate (25, CCDC 1445810)}

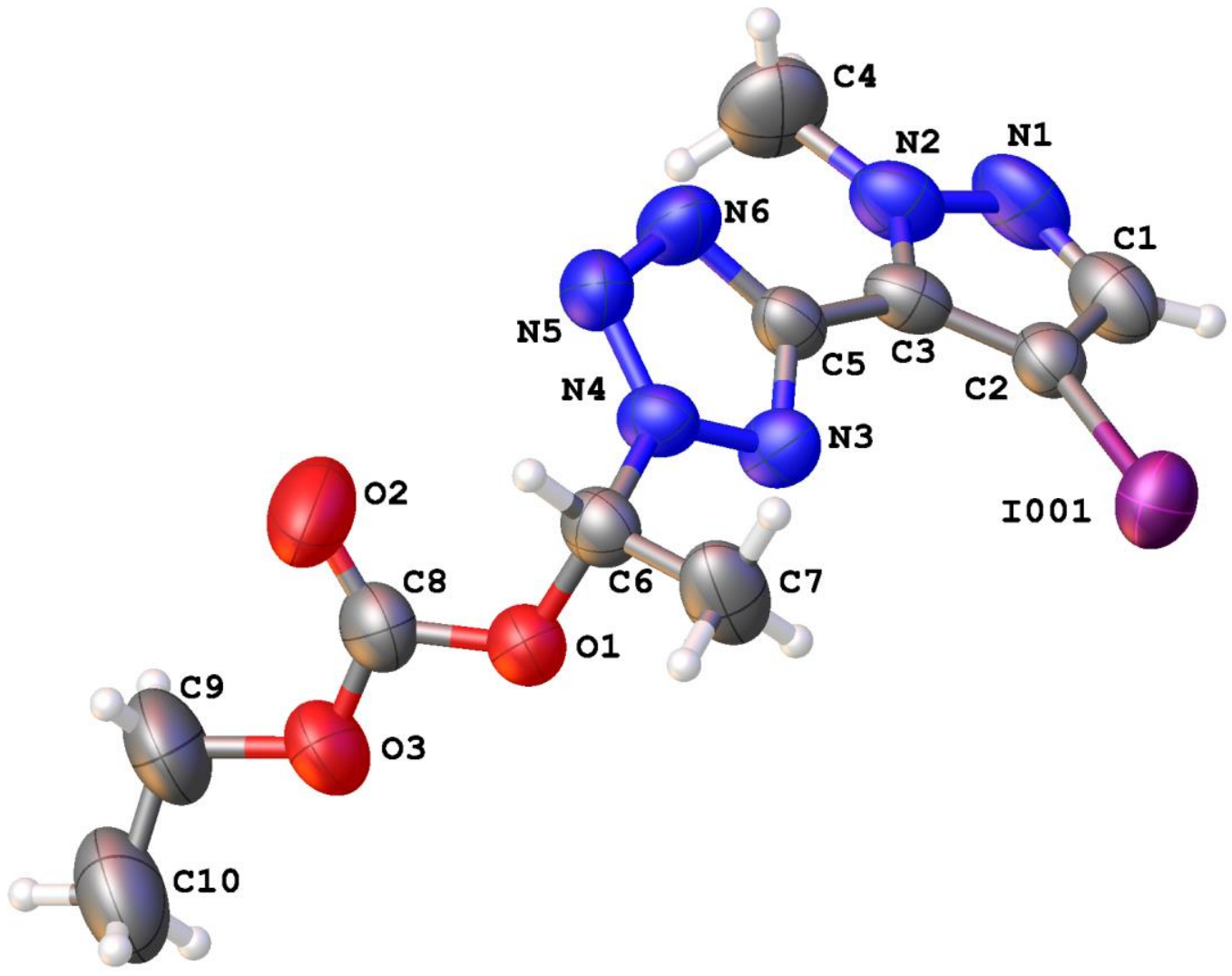

Figure S7. ORTEP drawing of $(S)$-ethyl 1-[5-(4-iodo-1-methyl-1 $H$-pyrazol-5-yl)-2H-tetrazol2-yl]ethyl carbonate (25)

Data collection was performed on a Bruker APEX diffractometer at room temperature. Data collection consisted of omega and phi scans. The structure was solved by direct methods using 
SHELX software suite in the space group $\mathrm{P} 2{ }_{1}$. The structure was subsequently refined by the full-matrix least squares method. All non-hydrogen atoms were found and refined using anisotropic displacement parameters. All hydrogen atoms were placed in calculated positions and were allowed to ride on their carrier atoms. The final refinement included isotropic displacement parameters for all hydrogen atoms. Absolute configuration was determined be examination of the Flack parameter. In this case, the parameter $=0.0396$ with an esd of 0.003 . These values are within range for absolute configuration determination. The final R-index was 3.5\%. A final difference Fourier revealed no missing or misplaced electron density.

Pertinent crystal, data collection and refinement are summarized in Table S5.

Table S5. Crystal data and structure refinement for $(S)$-ethyl 1-[5-(4-iodo-1-methyl-1Hpyrazol-5-yl)-2H-tetrazol-2-yl]ethyl carbonate (25)

Empirical formula

Formula weight

Temperature

Wavelength

Crystal system

Space group

Unit cell dimensions

Volume

Z

Density (calculated)

Absorption coefficient

$\mathrm{F}(000)$

Crystal size

Theta range for data collection

Index ranges

Reflections collected

Independent reflections

Completeness to theta $=70.22^{\circ}$

Absorption correction
$\mathrm{C}_{10} \mathrm{H}_{13} \mathrm{IN}_{6} \mathrm{O}_{3}$

392.16

293(2) K

$1.54178 \AA$

Monoclinic

P2(1)

$\mathrm{a}=4.5885(4) \AA$

$\alpha=90^{\circ}$.

$\mathrm{b}=10.0115(9) \AA$

$\beta=90.413(5)^{\circ}$.

$\mathrm{c}=16.2053(13) \AA$

$\gamma=90^{\circ}$.

744.42(11) $\AA^{3}$

2

$1.750 \mathrm{Mg} / \mathrm{m}^{3}$

$17.076 \mathrm{~mm}^{-1}$

384

$0.31 \times 0.1 \times 0.08 \mathrm{~mm}^{3}$

5.19 to $70.22^{\circ}$.

$-5<=\mathrm{h}<=5,-12<=\mathrm{k}<=11,-18<=\mathrm{l}<=18$

12126

$2625[\mathrm{R}(\mathrm{int})=0.0527]$

$95.5 \%$

None 
Refinement method

Data / restraints / parameters

Goodness-of-fit on $\mathrm{F}^{2}$

Final R indices [I $>2 \operatorname{sigma}(\mathrm{I})]$

$\mathrm{R}$ indices (all data)

Absolute structure parameter

Largest diff. peak and hole
Full-matrix least-squares on $\mathrm{F}^{2}$

$2625 / 1 / 184$

1.039

$\mathrm{R} 1=0.0355, \mathrm{wR} 2=0.0787$

$\mathrm{R} 1=0.0511, \mathrm{wR} 2=0.0864$

$0.040(10)$

0.727 and -0.373 e. $\AA^{-3}$ 


\section{Spectroscopic Data}

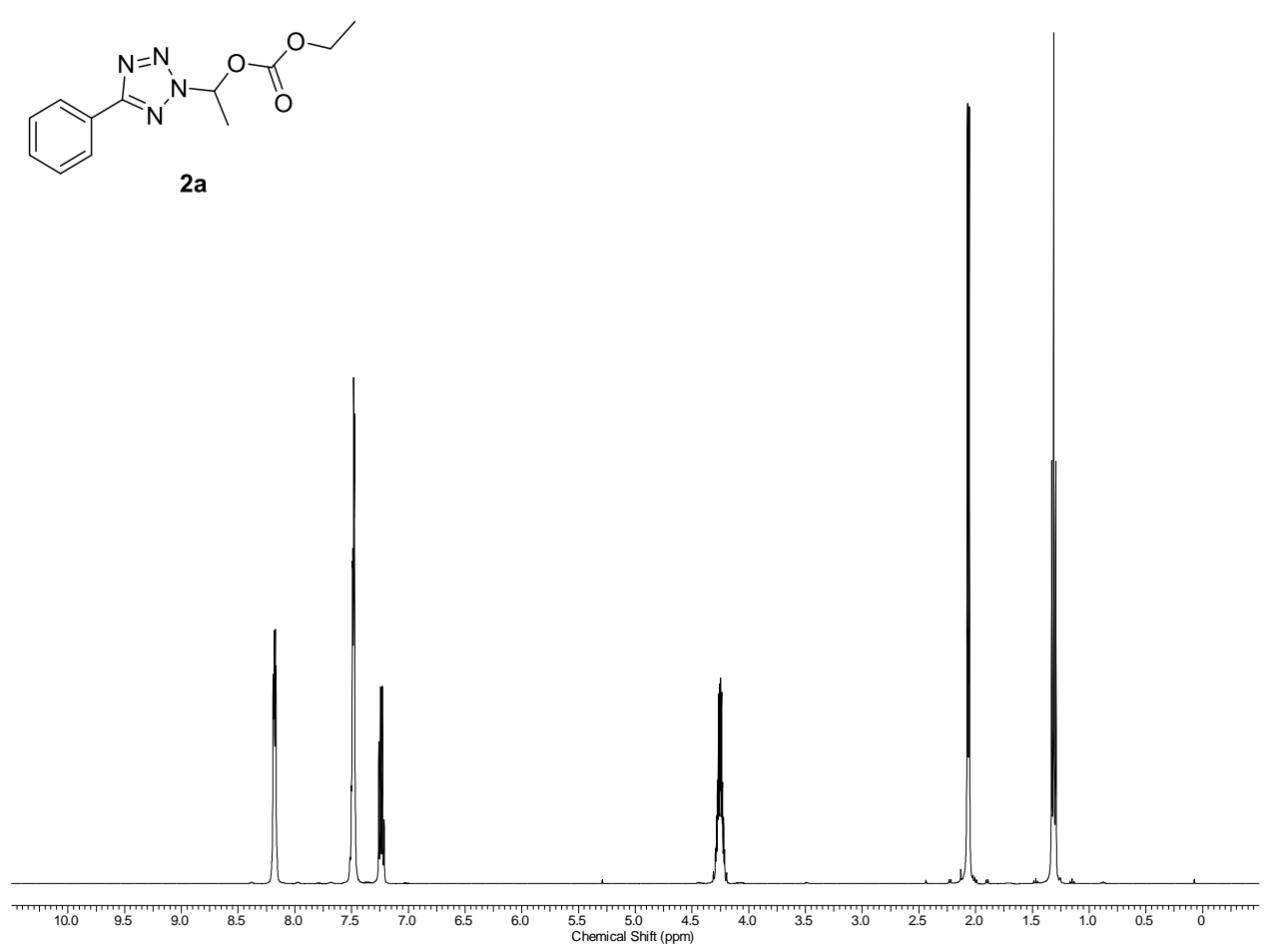

${ }^{1} \mathrm{H}$ NMR $\left(\mathrm{CDCl}_{3}, 25^{\circ} \mathrm{C}\right)$

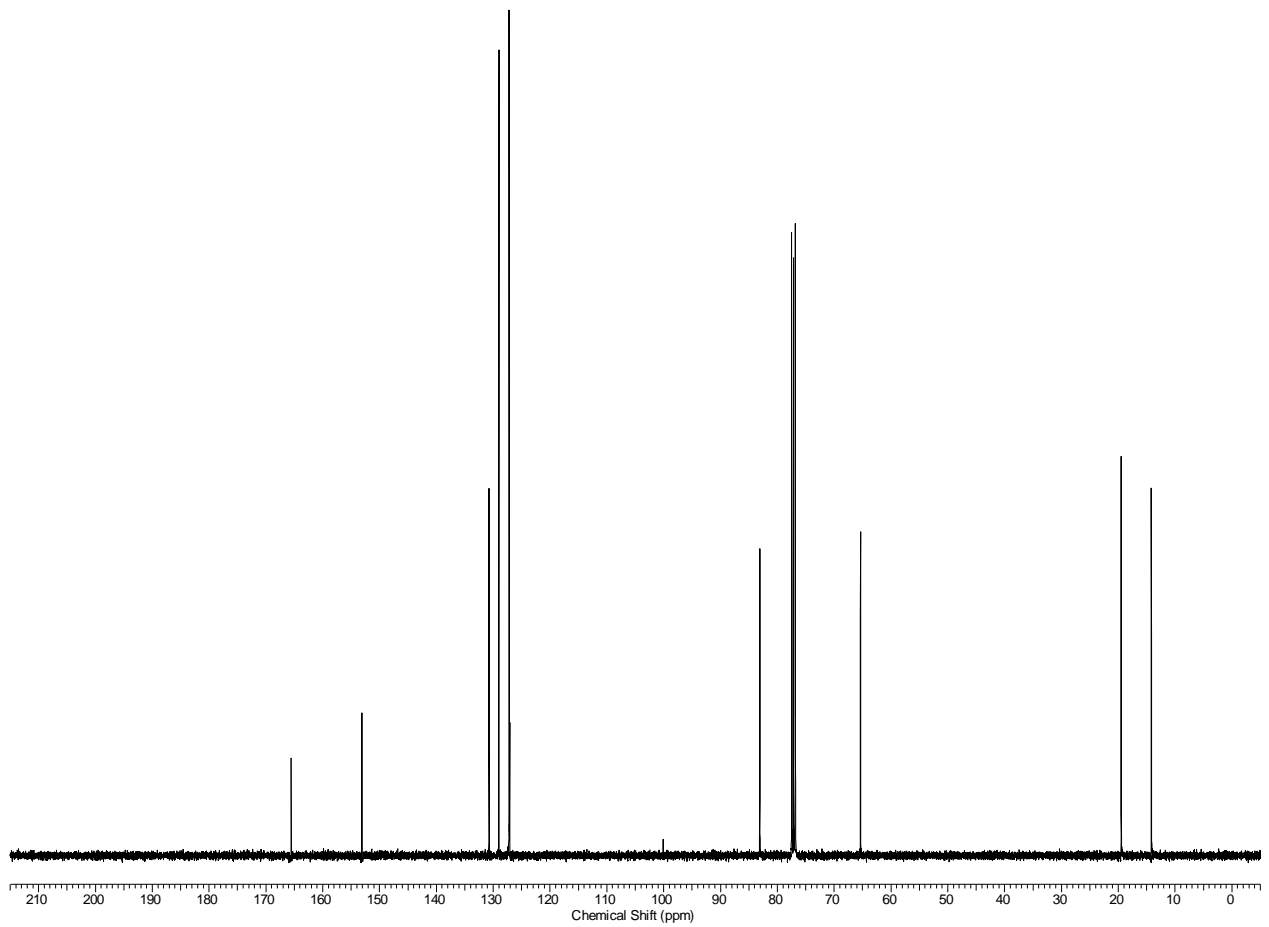

${ }^{13} \mathrm{C}$ NMR $\left(\mathrm{CDCl}_{3}, 25{ }^{\circ} \mathrm{C}\right)$ 


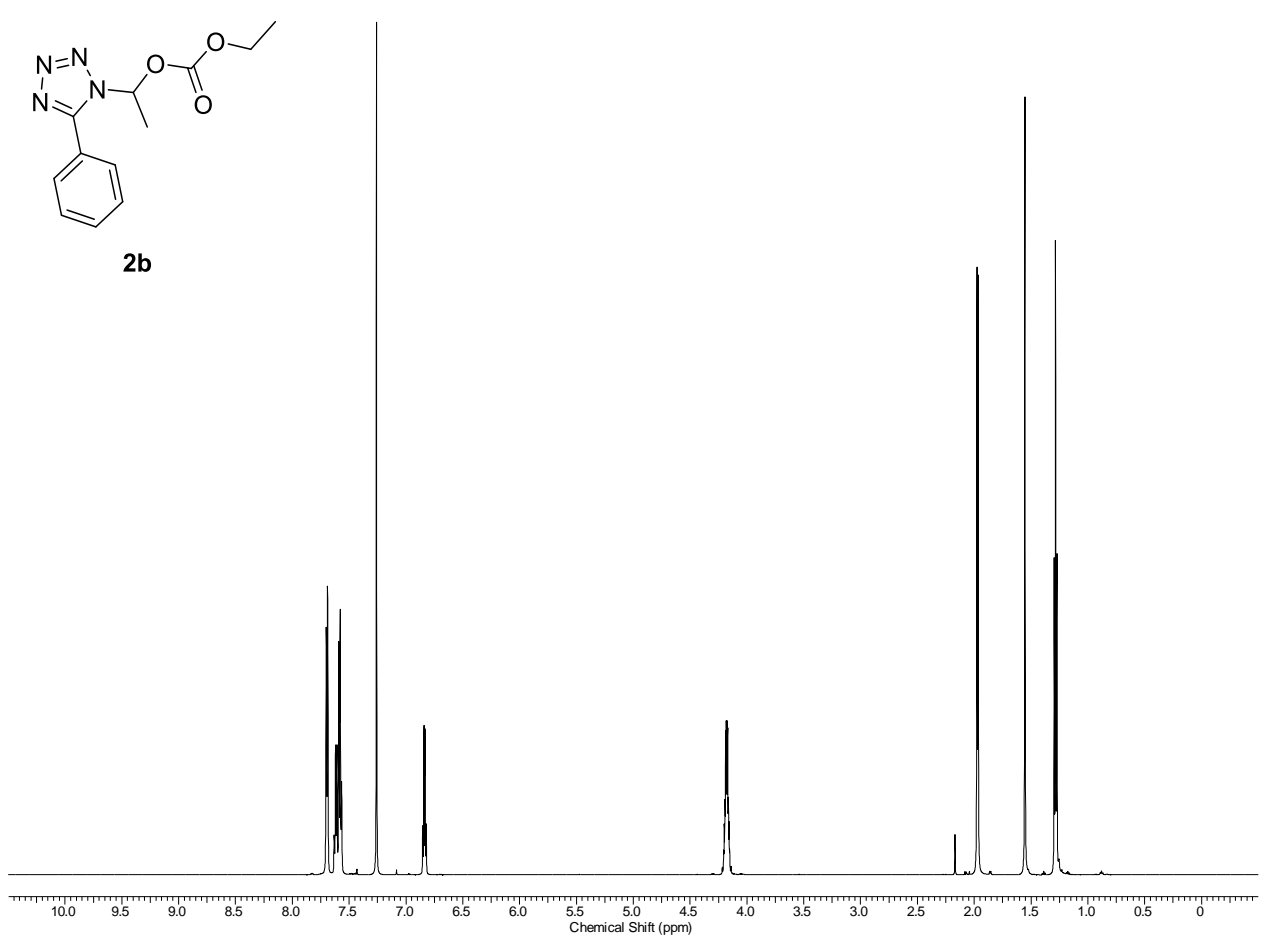

${ }^{1} \mathrm{H} \operatorname{NMR}\left(\mathrm{CDCl}_{3}, 25{ }^{\circ} \mathrm{C}\right)$

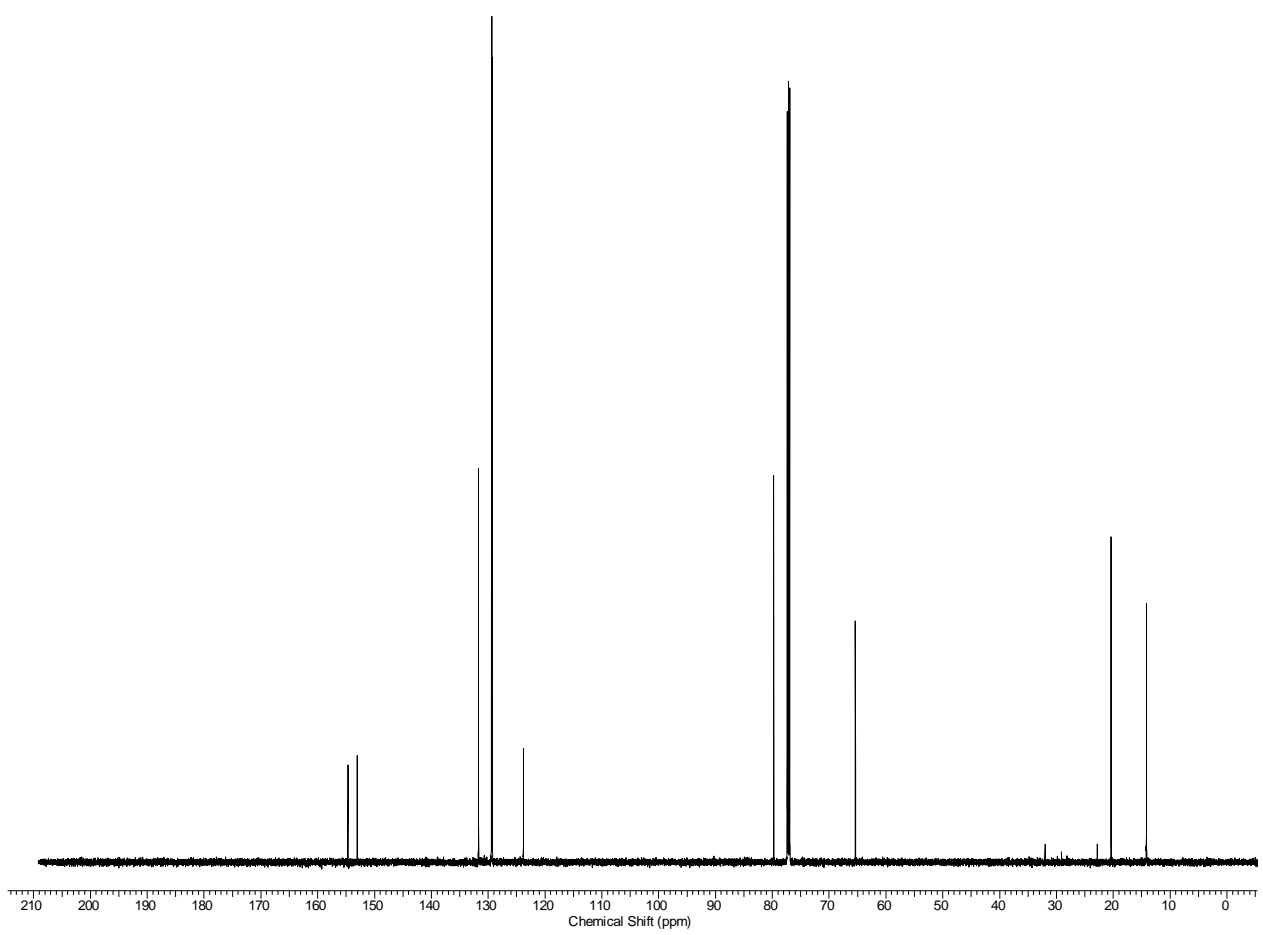

${ }^{13} \mathrm{C}$ NMR $\left(\mathrm{CDCl}_{3}, 25{ }^{\circ} \mathrm{C}\right)$ 


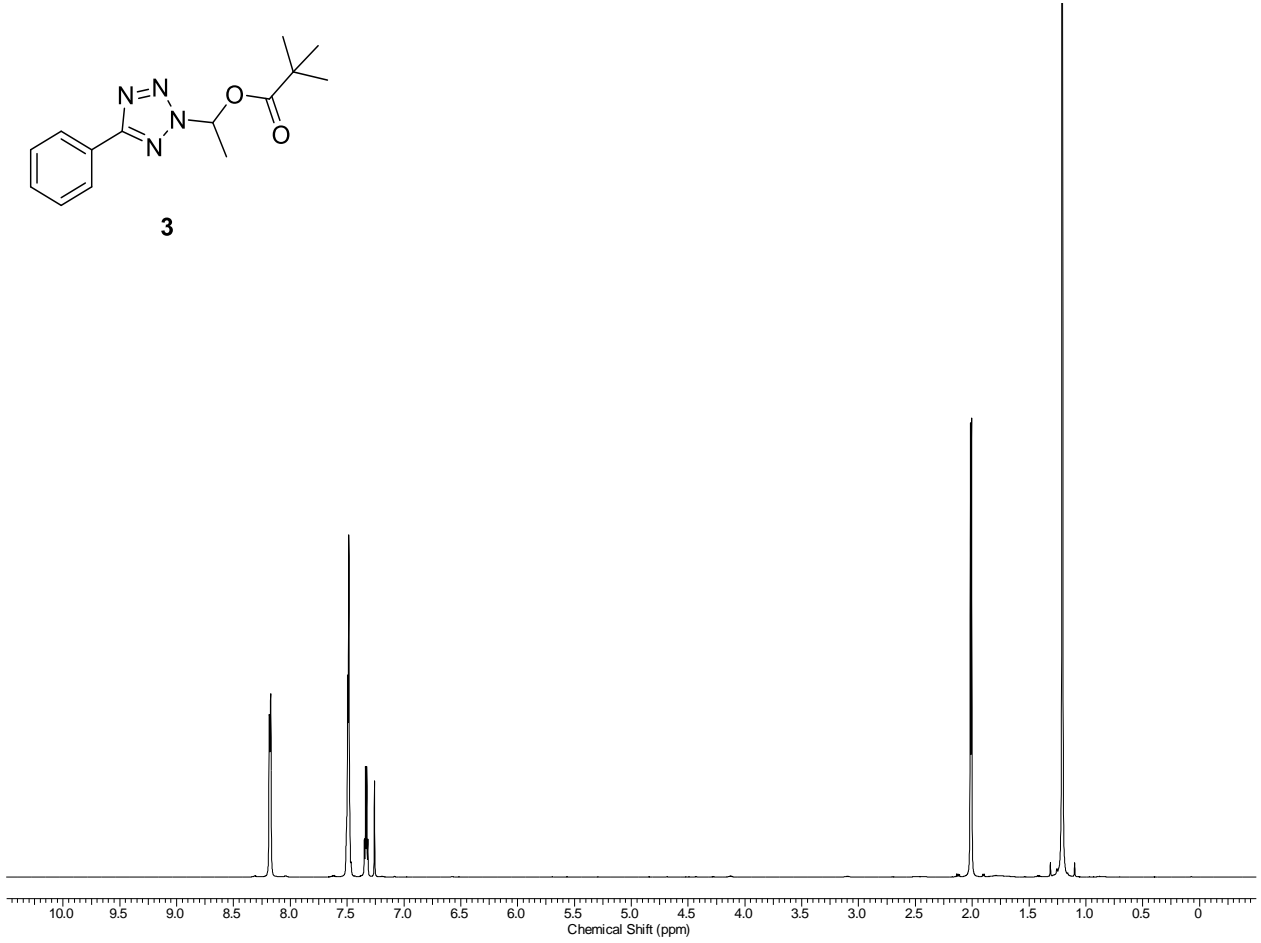

${ }^{1} \mathrm{H} \operatorname{NMR}\left(\mathrm{CDCl}_{3}, 25{ }^{\circ} \mathrm{C}\right)$

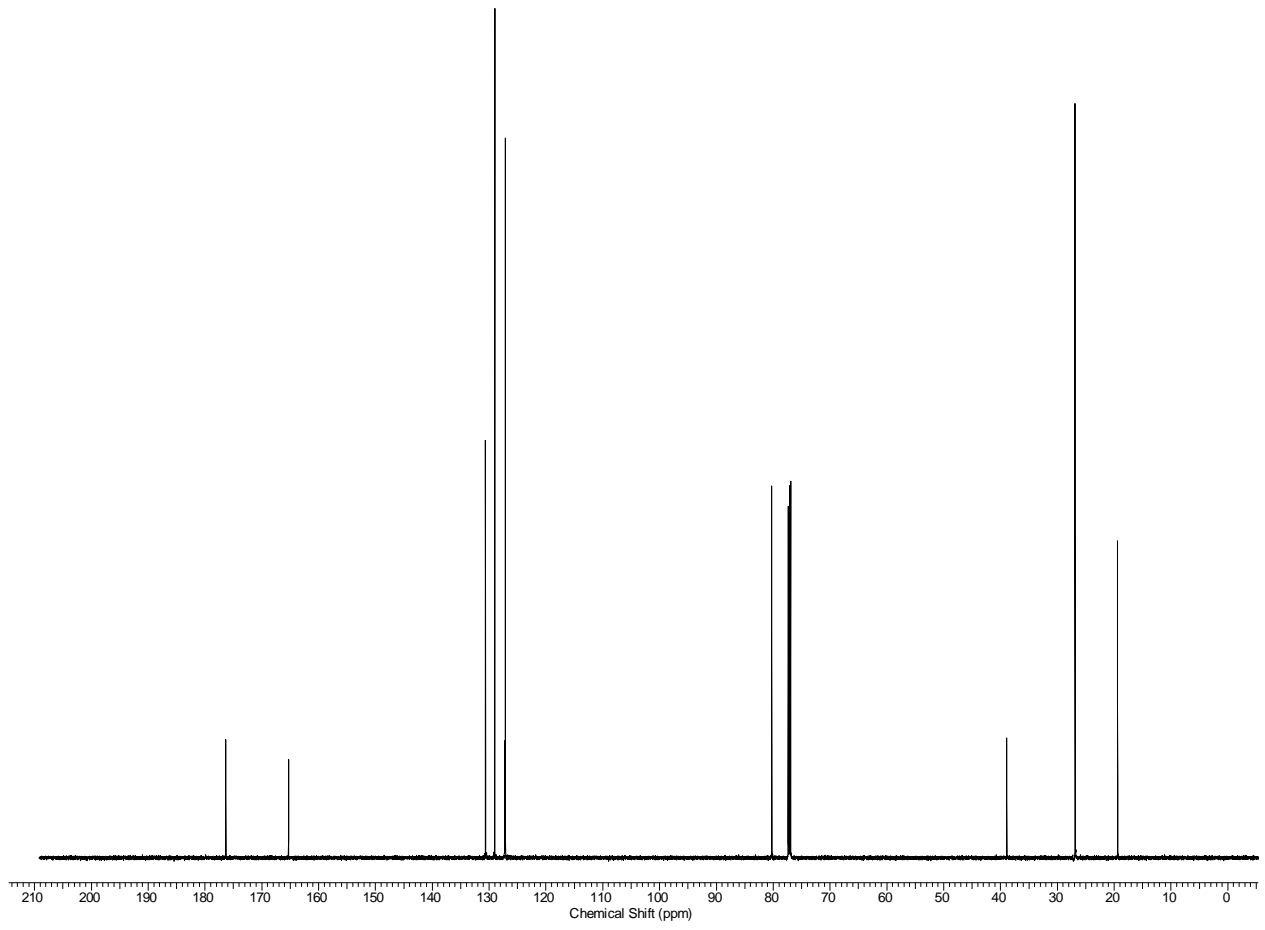

${ }^{13} \mathrm{C}$ NMR $\left(\mathrm{CDCl}_{3}, 25{ }^{\circ} \mathrm{C}\right)$ 


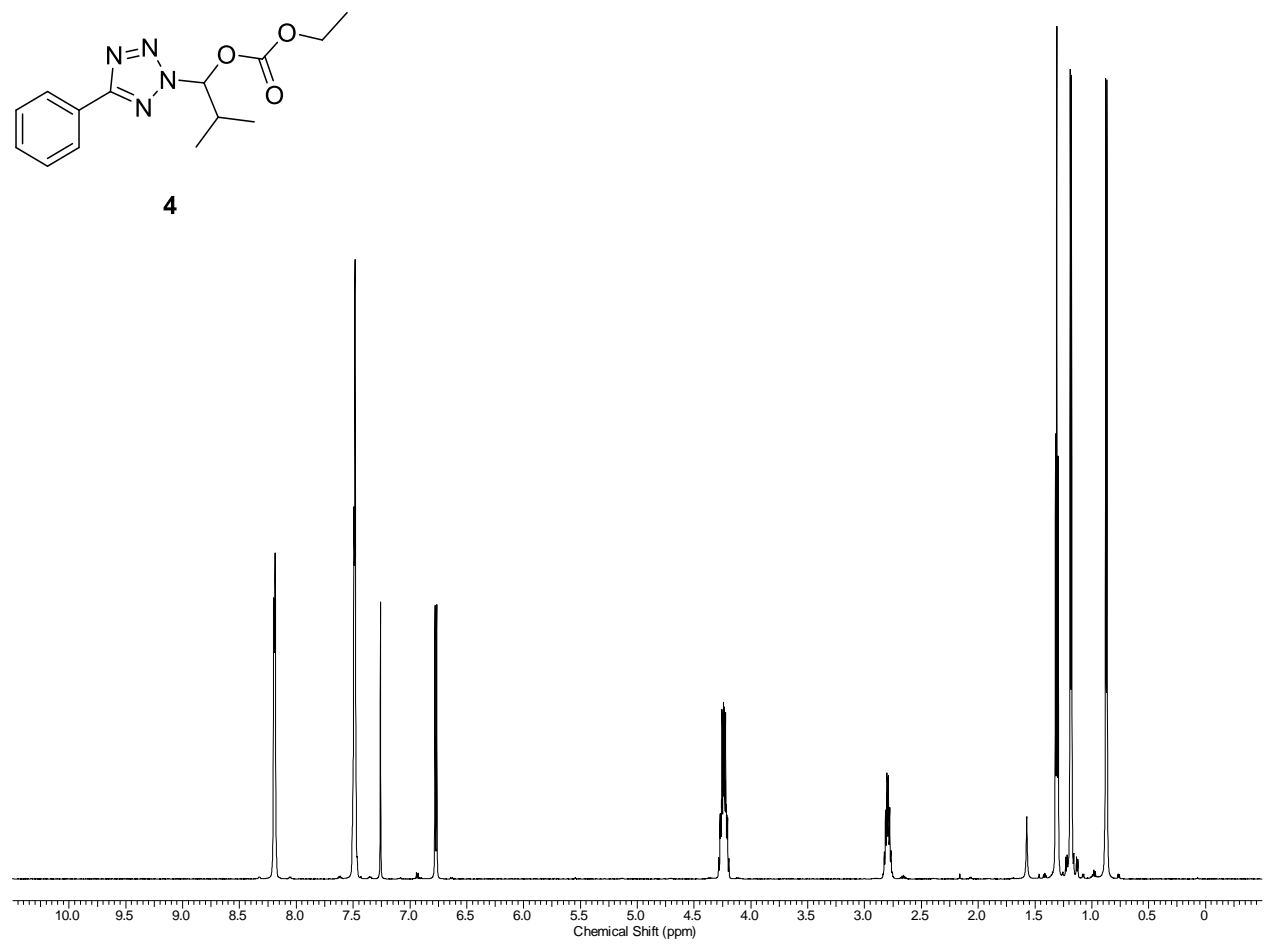

${ }^{1} \mathrm{H} \operatorname{NMR}\left(\mathrm{CDCl}_{3}, 25{ }^{\circ} \mathrm{C}\right)$

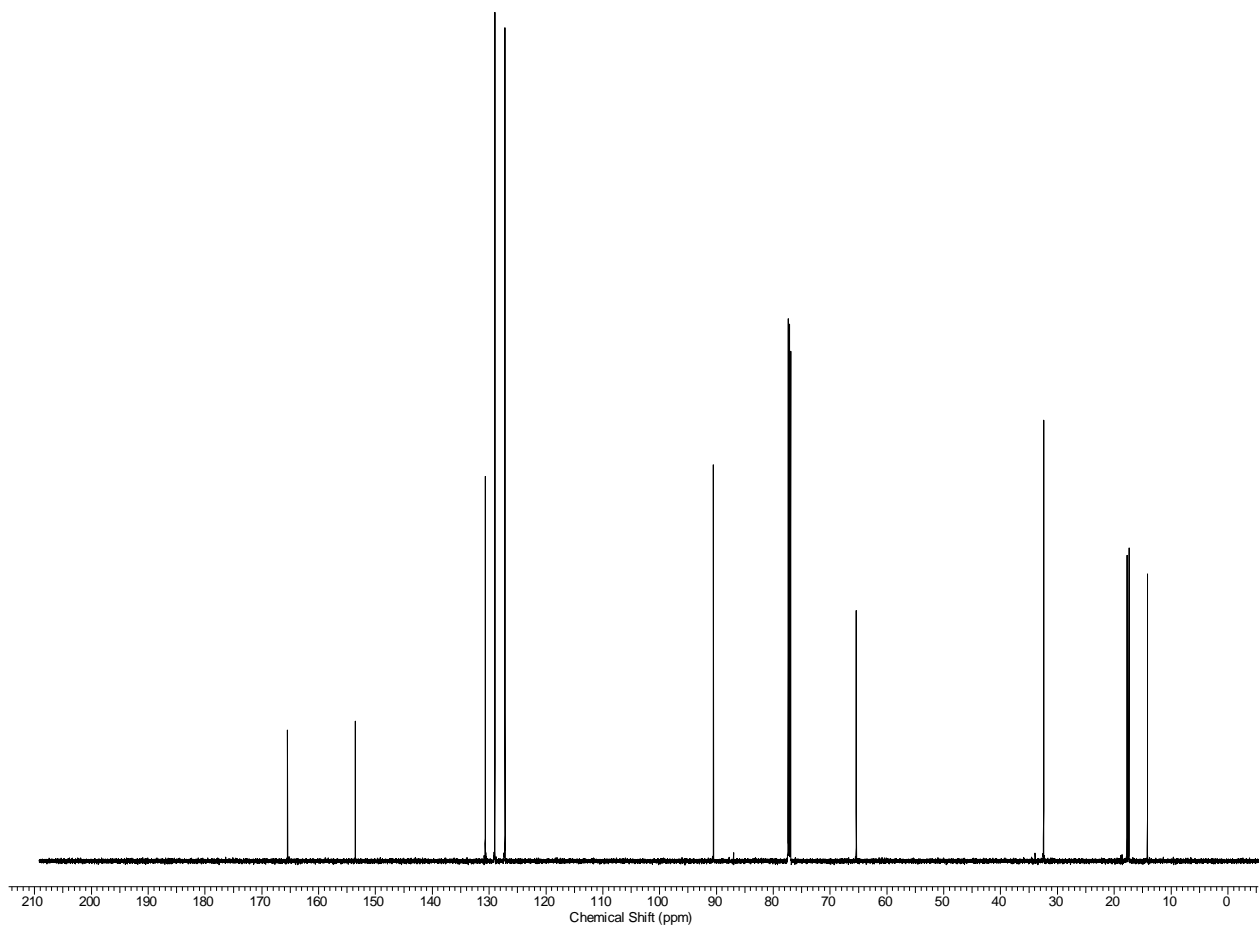

${ }^{13} \mathrm{C}$ NMR $\left(\mathrm{CDCl}_{3}, 25{ }^{\circ} \mathrm{C}\right)$ 

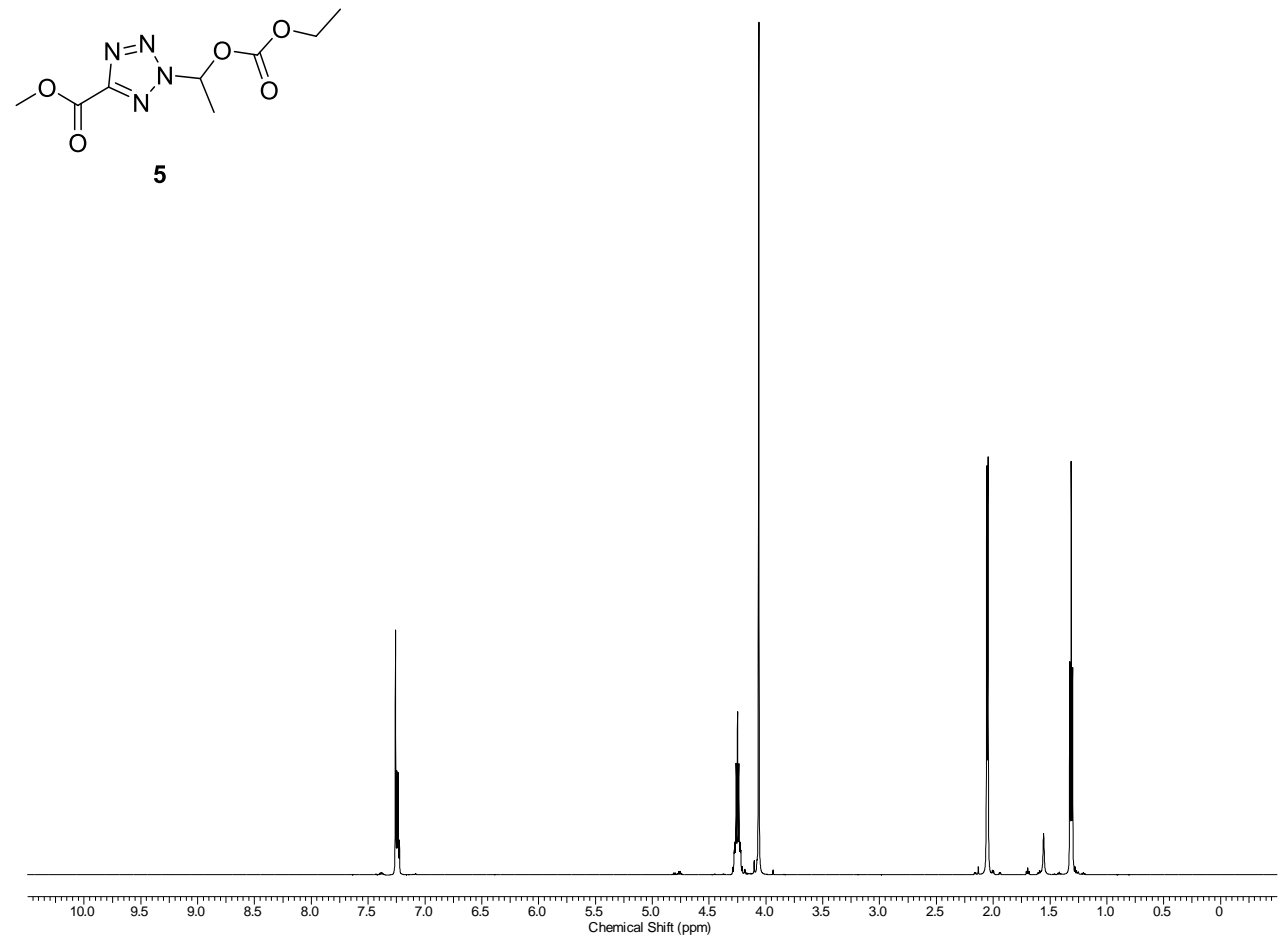

${ }^{1} \mathrm{H} \operatorname{NMR}\left(\mathrm{CDCl}_{3}, 25{ }^{\circ} \mathrm{C}\right)$

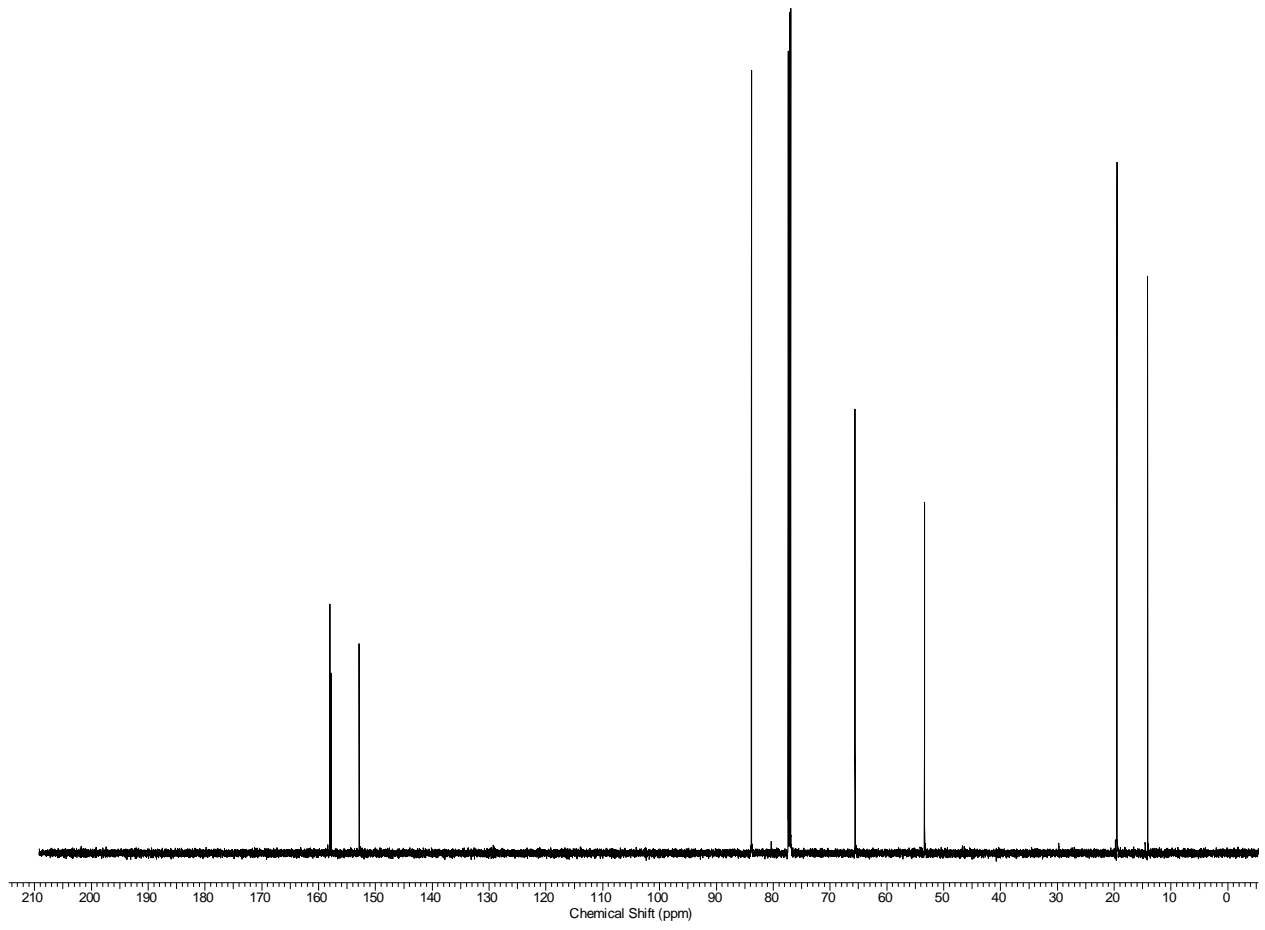

${ }^{13} \mathrm{C}$ NMR $\left(\mathrm{CDCl}_{3}, 25{ }^{\circ} \mathrm{C}\right)$ 


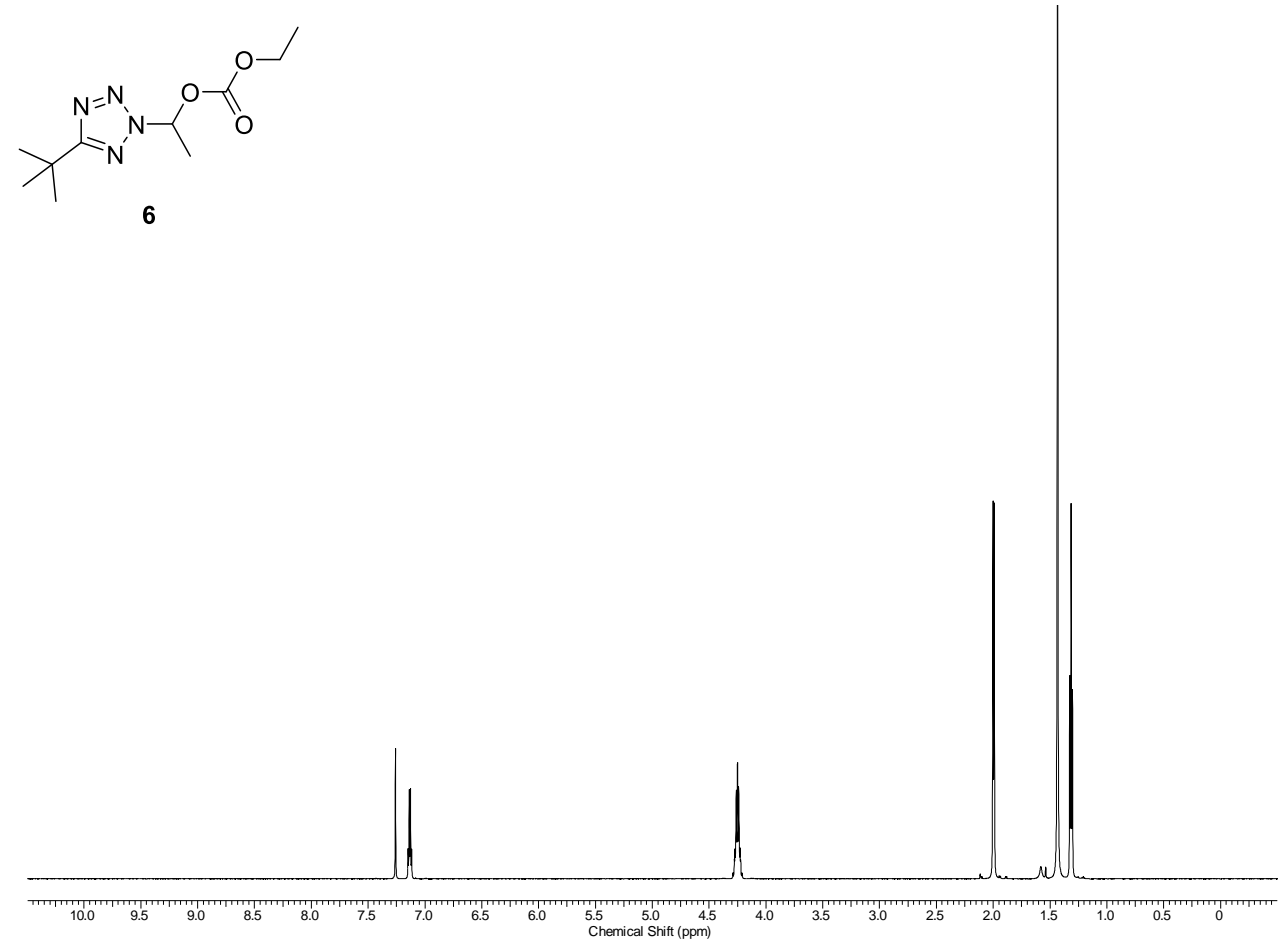

${ }^{1} \mathrm{H} \operatorname{NMR}\left(\mathrm{CDCl}_{3}, 25{ }^{\circ} \mathrm{C}\right)$

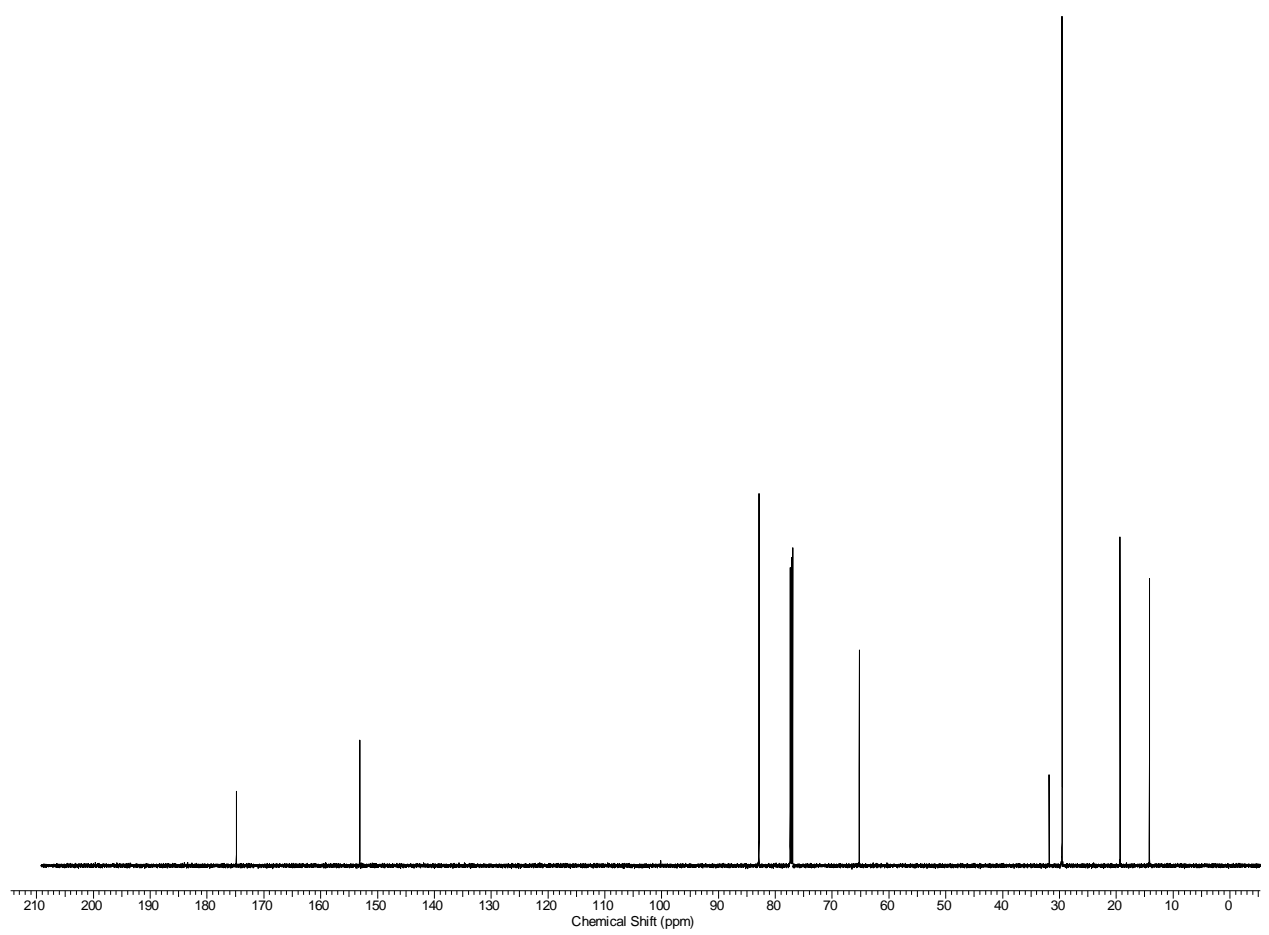

${ }^{13} \mathrm{C}$ NMR $\left(\mathrm{CDCl}_{3}, 25{ }^{\circ} \mathrm{C}\right)$ 

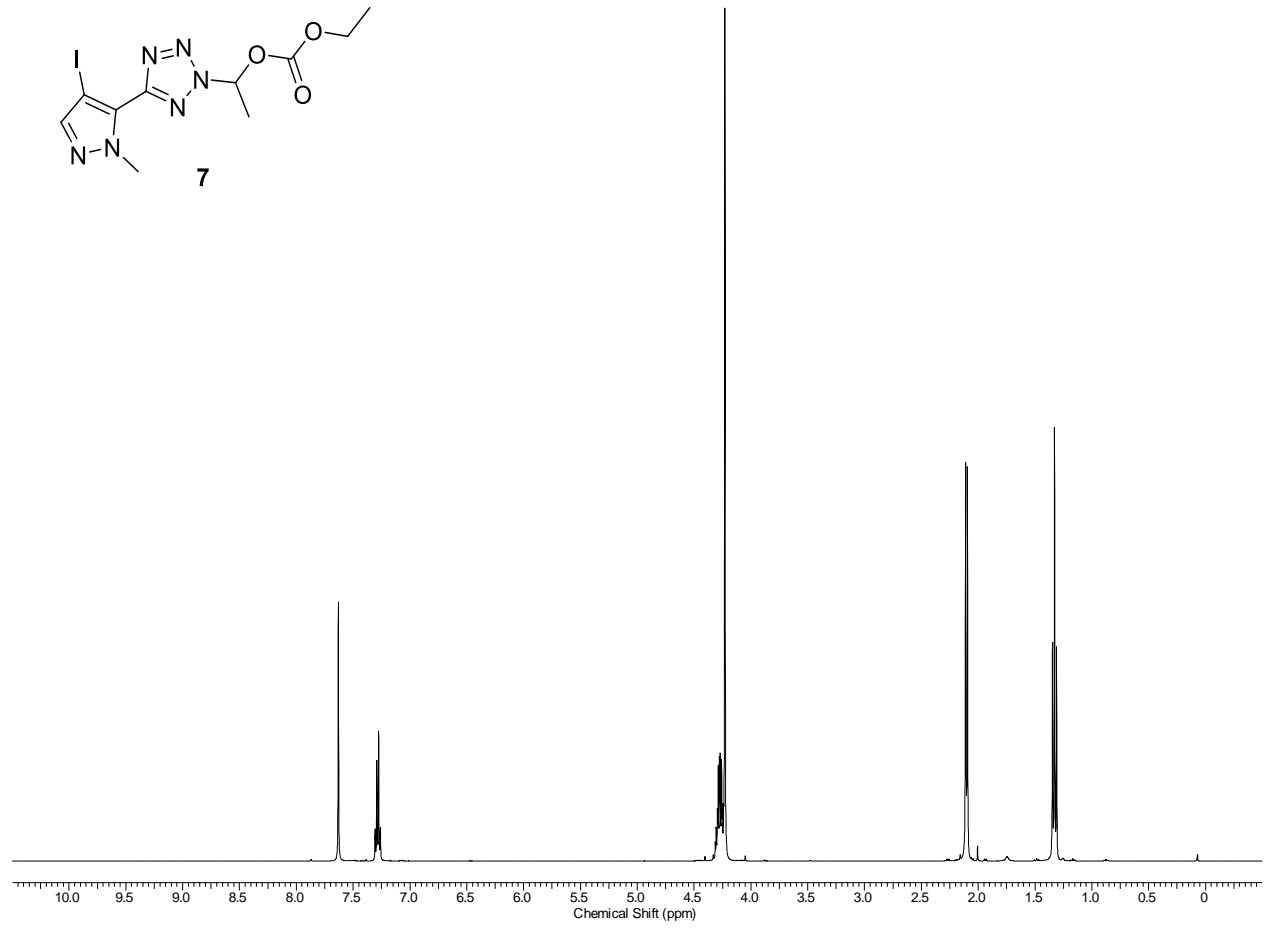

${ }^{1} \mathrm{H} \operatorname{NMR}\left(\mathrm{CDCl}_{3}, 25{ }^{\circ} \mathrm{C}\right)$

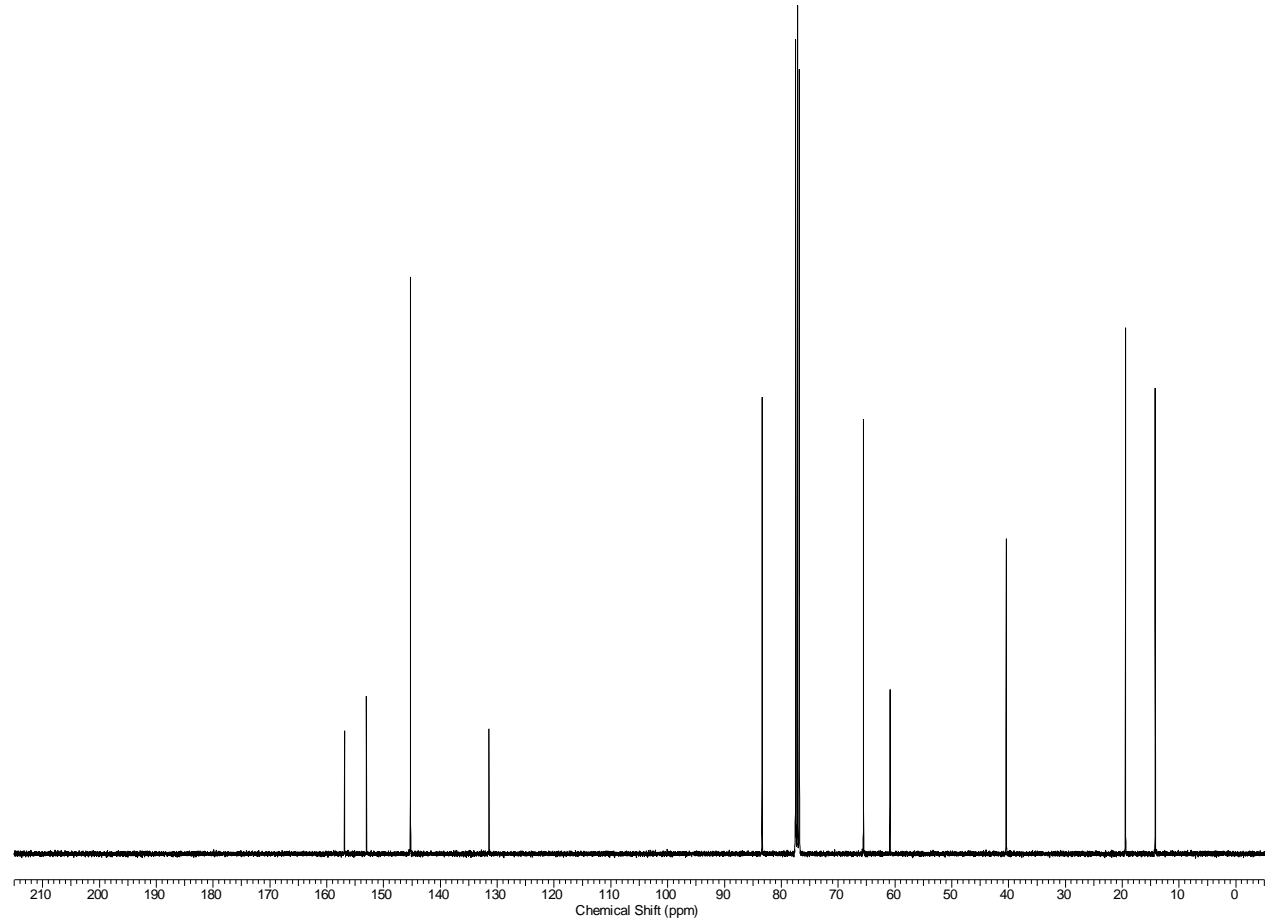

${ }^{13} \mathrm{C}$ NMR $\left(\mathrm{CDCl}_{3}, 25{ }^{\circ} \mathrm{C}\right)$ 


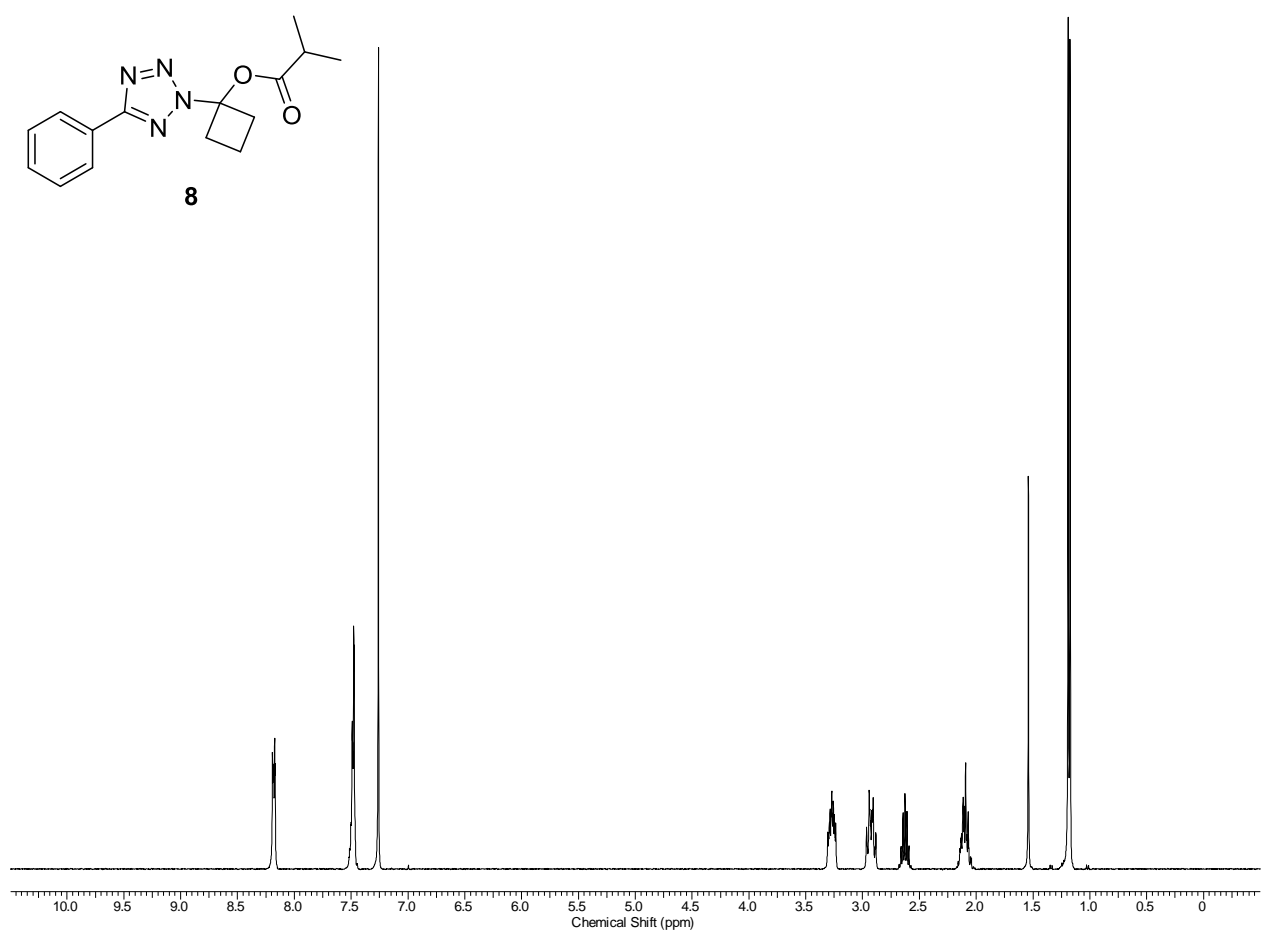

${ }^{1} \mathrm{H} \operatorname{NMR}\left(\mathrm{CDCl}_{3}, 25{ }^{\circ} \mathrm{C}\right)$

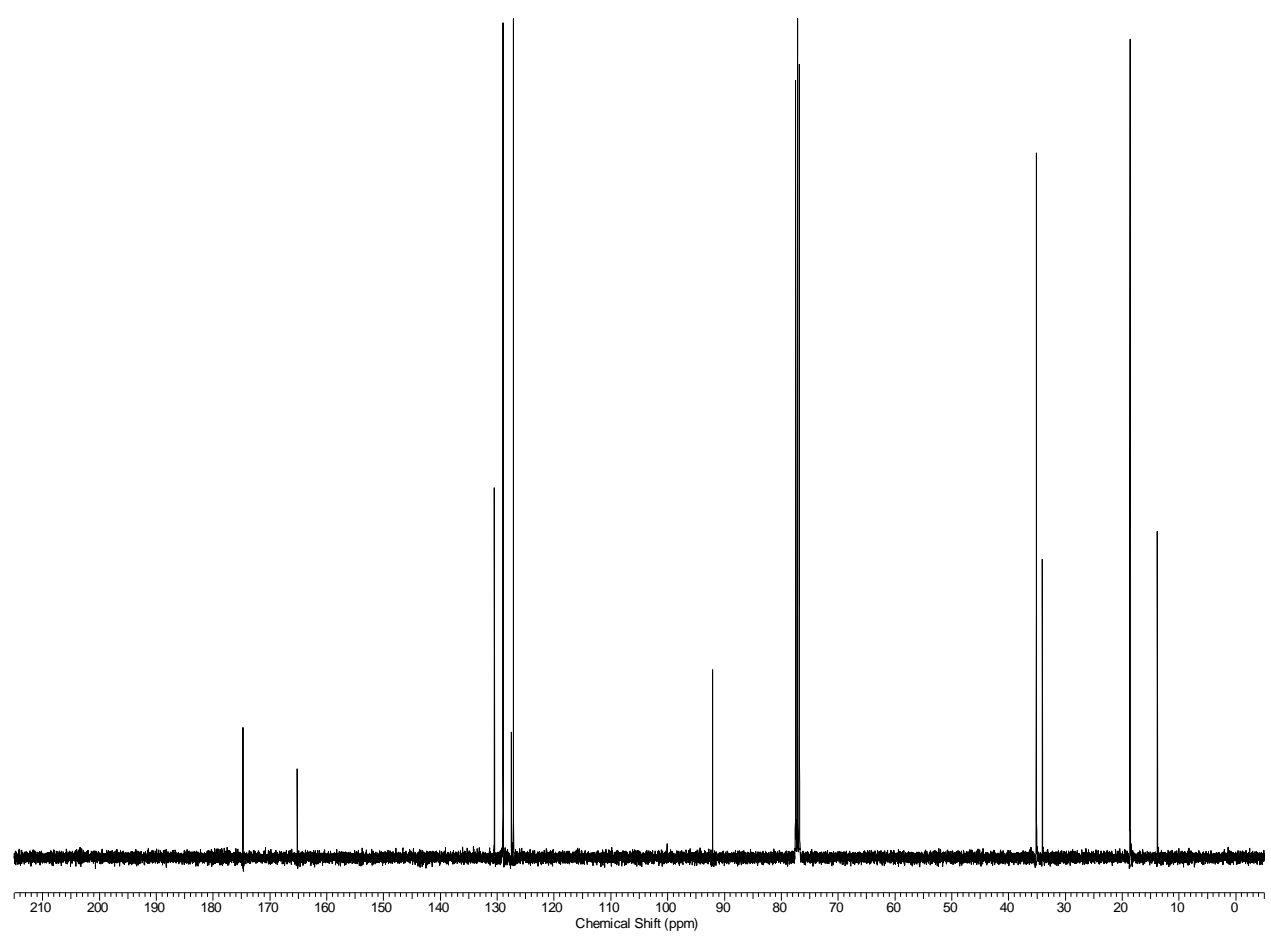

${ }^{13} \mathrm{C}$ NMR $\left(\mathrm{CDCl}_{3}, 25{ }^{\circ} \mathrm{C}\right)$ 

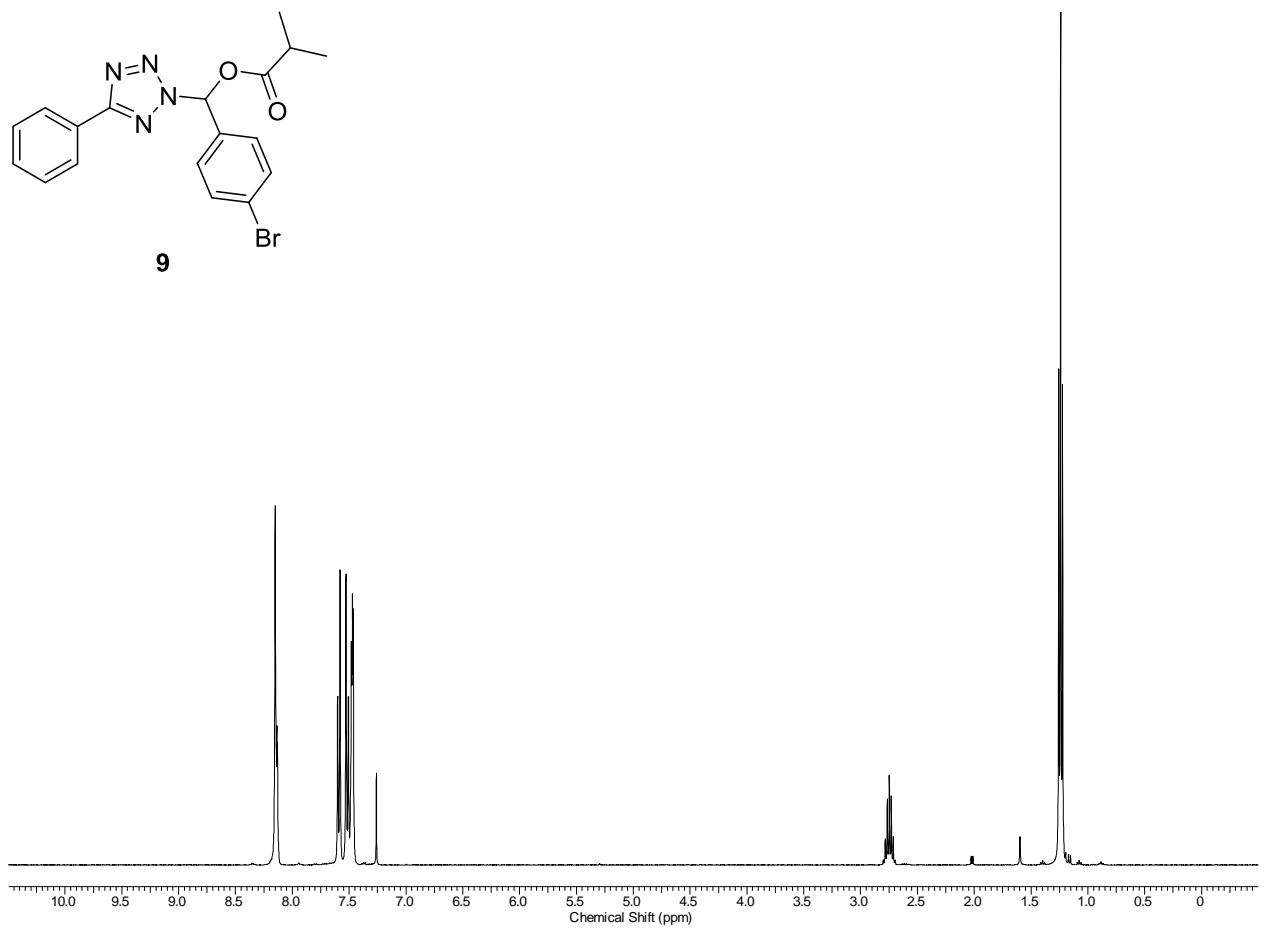

${ }^{1} \mathrm{H} \operatorname{NMR}\left(\mathrm{CDCl}_{3}, 25{ }^{\circ} \mathrm{C}\right)$

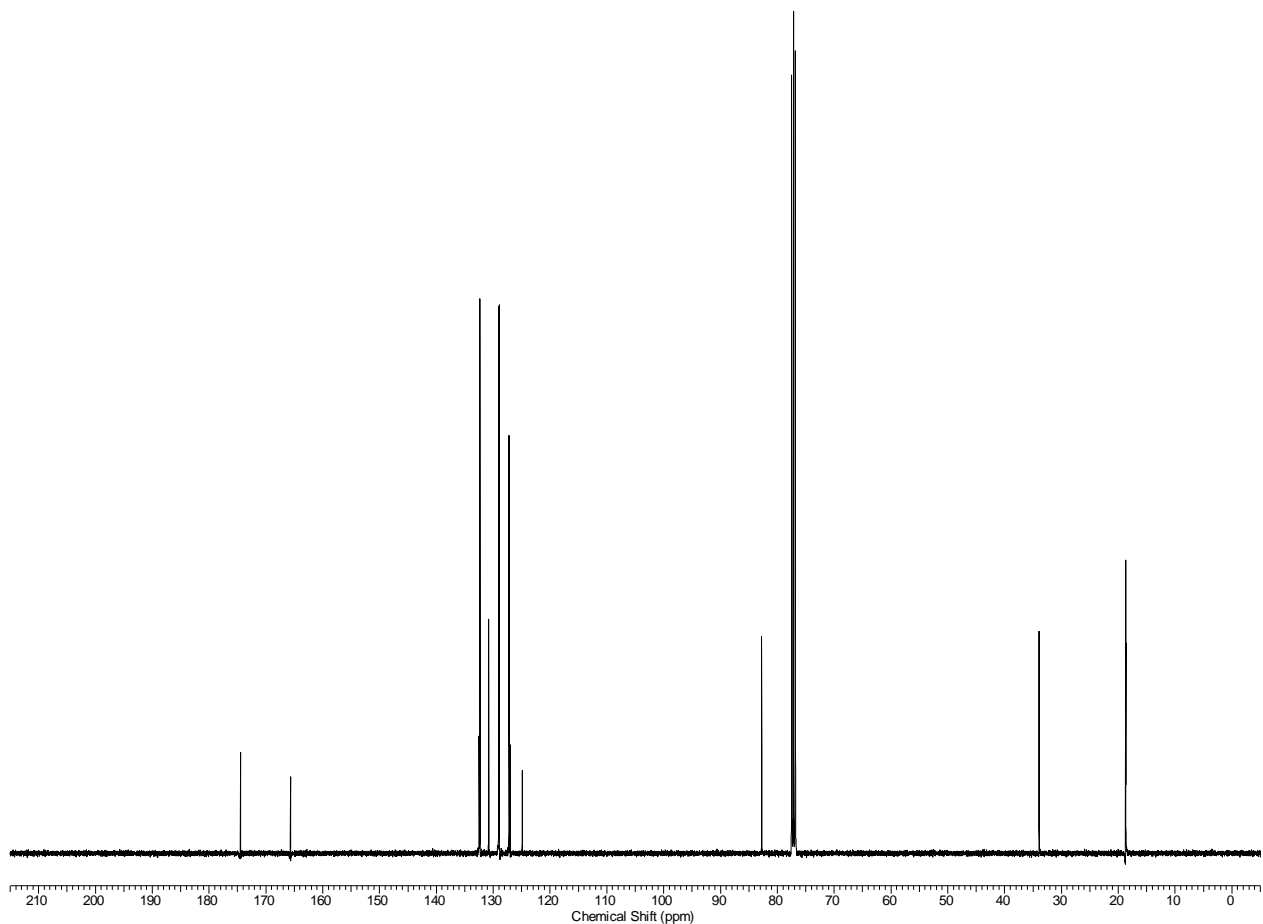

${ }^{13} \mathrm{C}$ NMR $\left(\mathrm{CDCl}_{3}, 25{ }^{\circ} \mathrm{C}\right)$ 


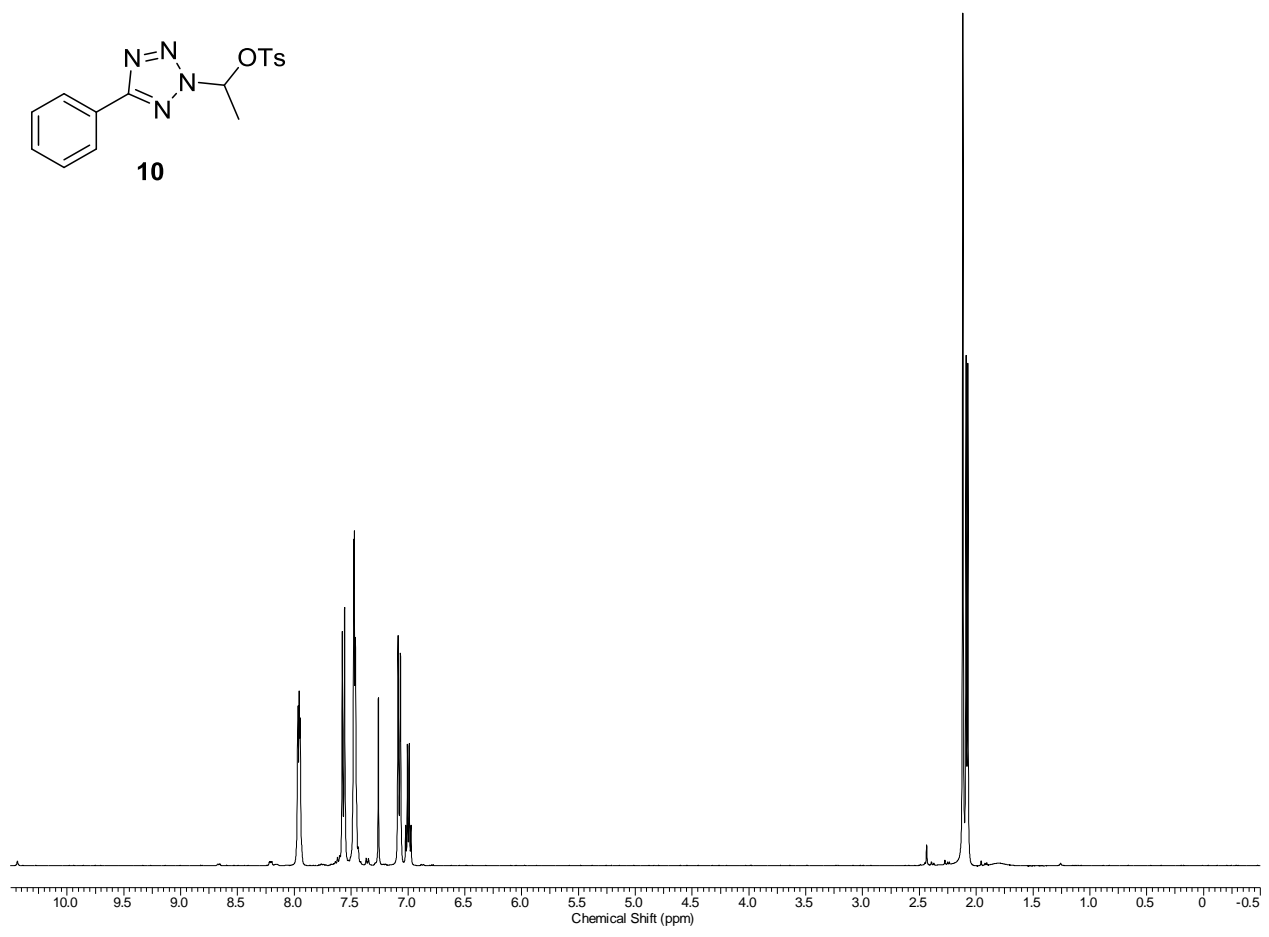

${ }^{1} \mathrm{H} \operatorname{NMR}\left(\mathrm{CDCl}_{3}, 25{ }^{\circ} \mathrm{C}\right)$

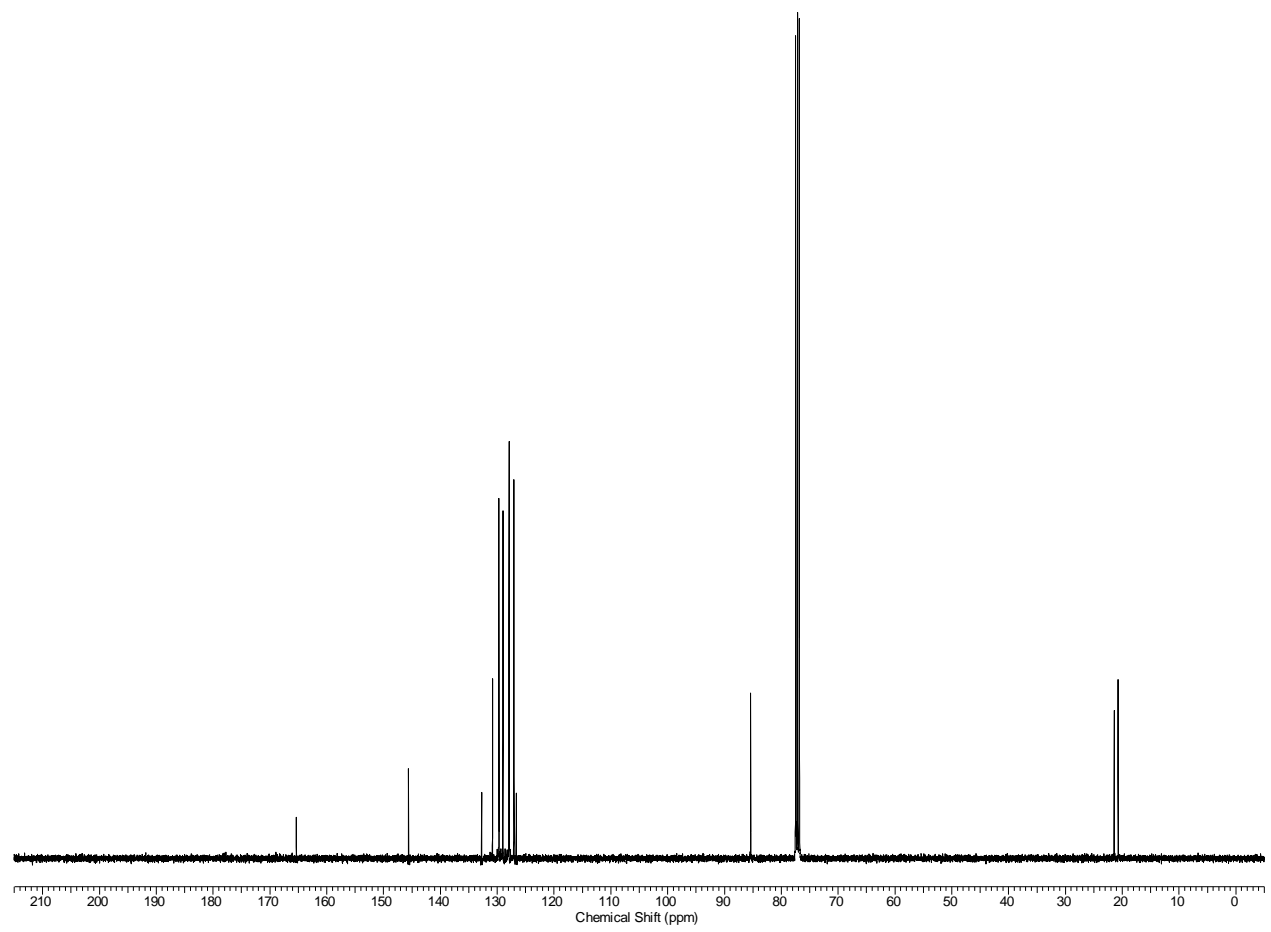

${ }^{13} \mathrm{C}$ NMR $\left(\mathrm{CDCl}_{3}, 25{ }^{\circ} \mathrm{C}\right)$ 


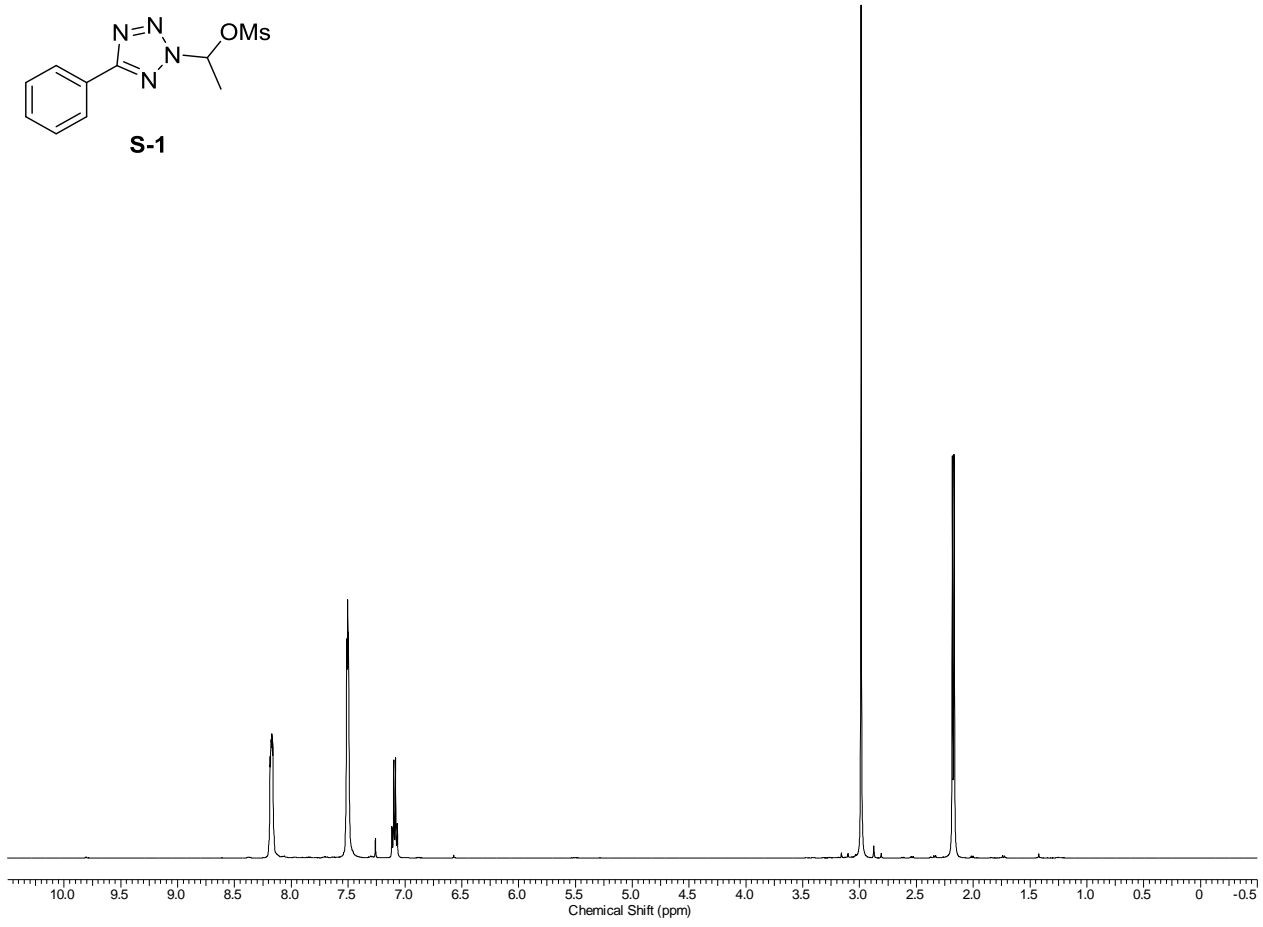

${ }^{1} \mathrm{H} \operatorname{NMR}\left(\mathrm{CDCl}_{3}, 25{ }^{\circ} \mathrm{C}\right)$

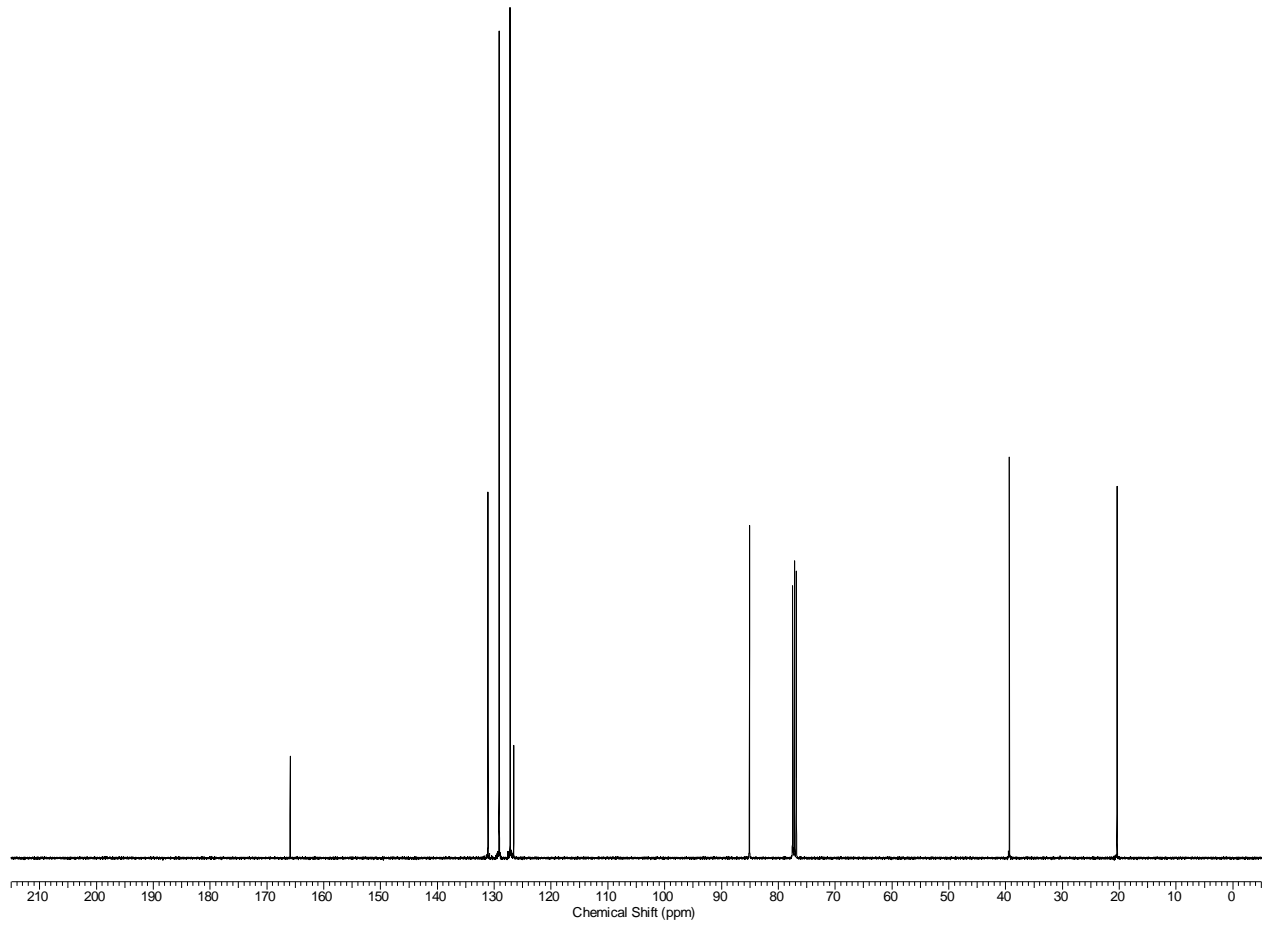

${ }^{13} \mathrm{C}$ NMR $\left(\mathrm{CDCl}_{3}, 25{ }^{\circ} \mathrm{C}\right)$ 


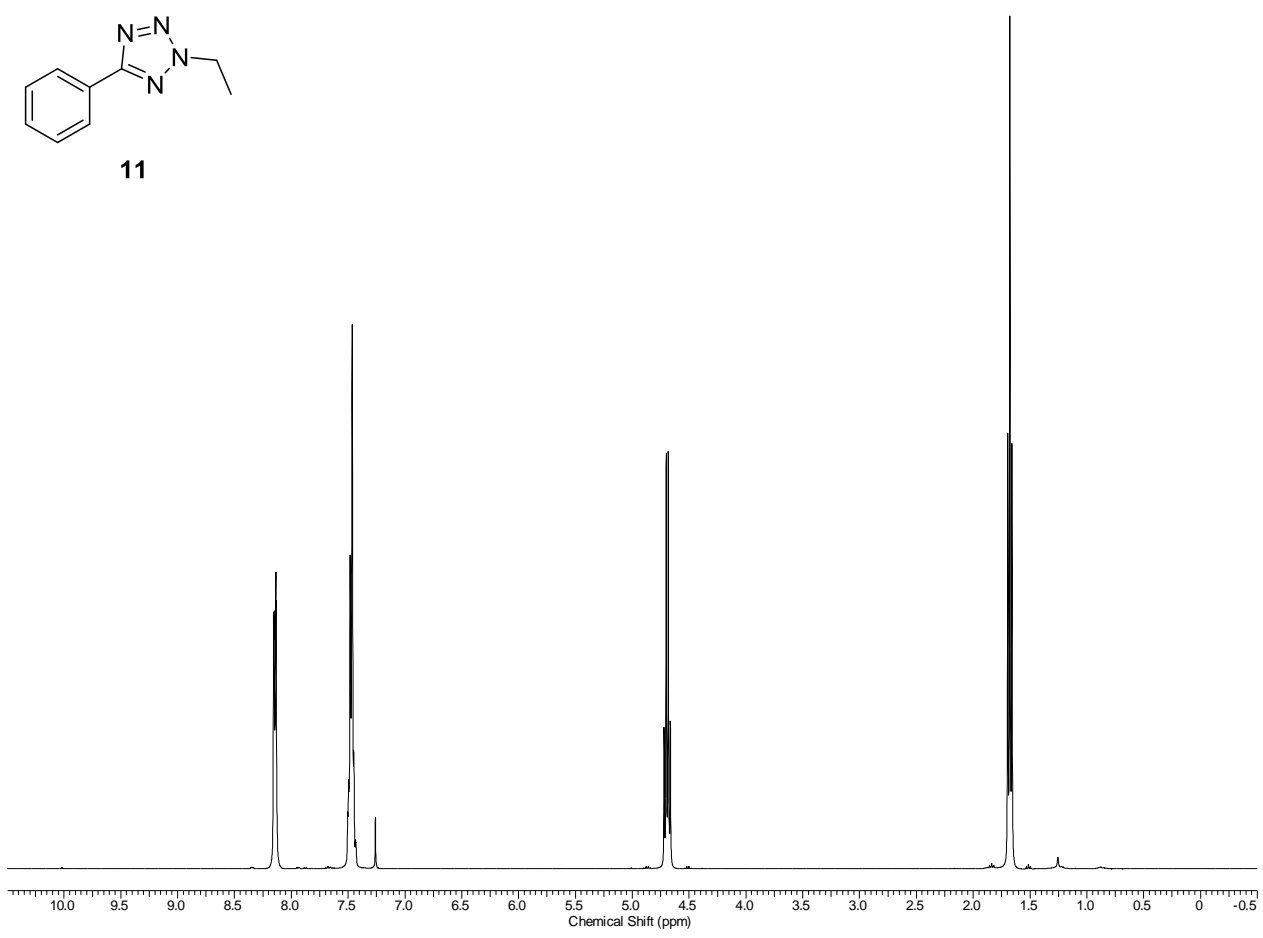

${ }^{1} \mathrm{H} \operatorname{NMR}\left(\mathrm{CDCl}_{3}, 25{ }^{\circ} \mathrm{C}\right)$

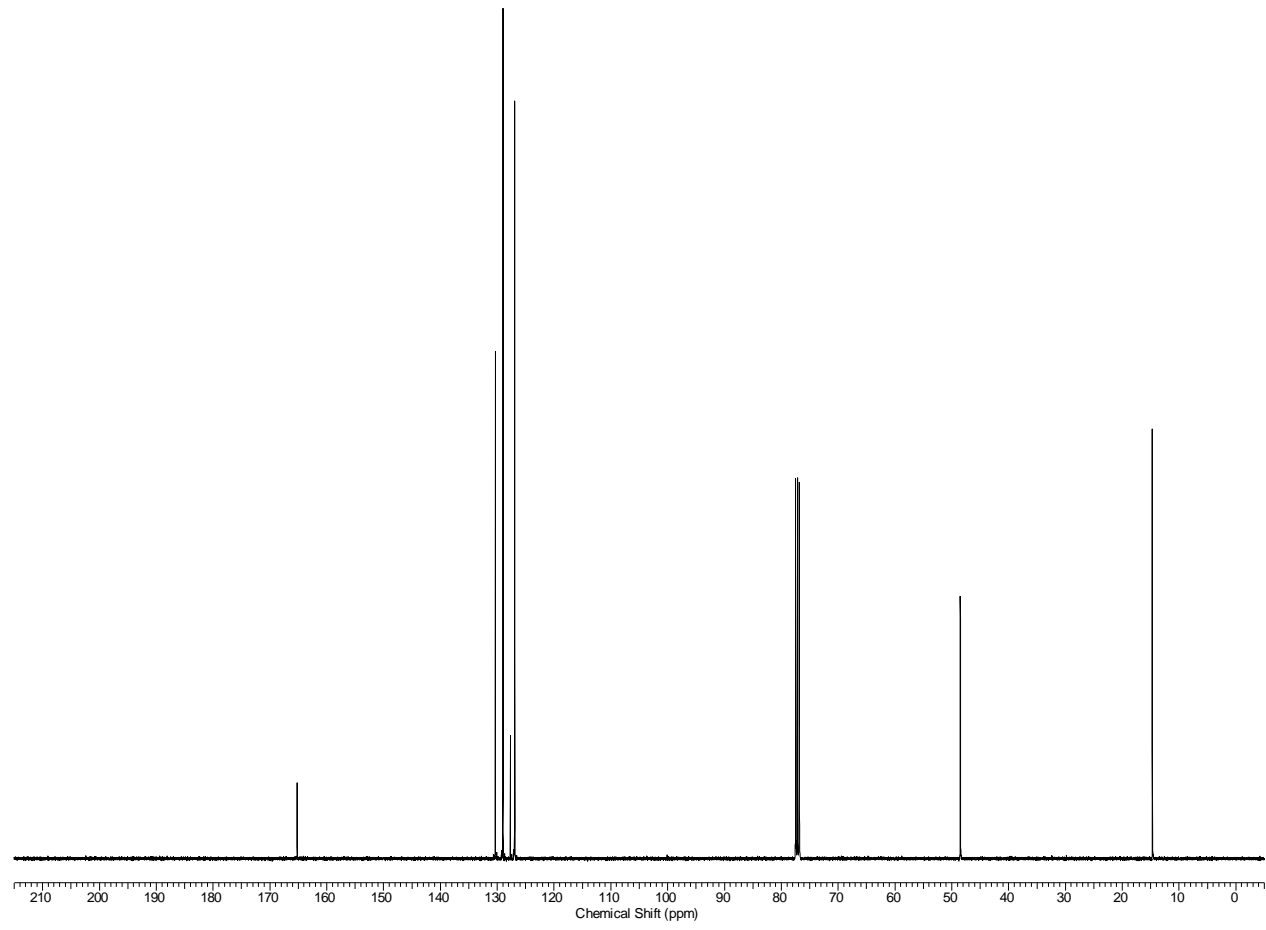

${ }^{13} \mathrm{C}$ NMR $\left(\mathrm{CDCl}_{3}, 25{ }^{\circ} \mathrm{C}\right)$ 


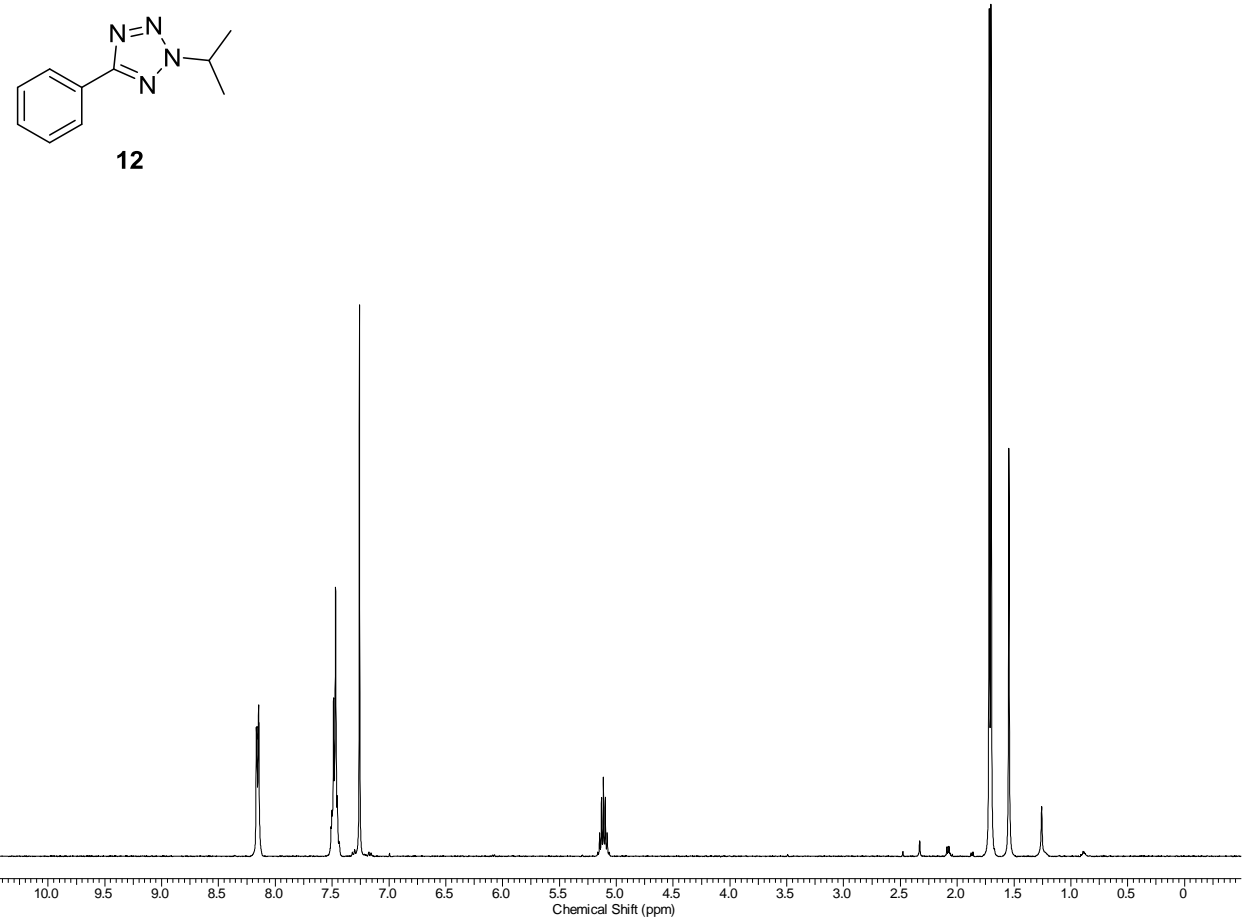

${ }^{1} \mathrm{H} \operatorname{NMR}\left(\mathrm{CDCl}_{3}, 25{ }^{\circ} \mathrm{C}\right)$

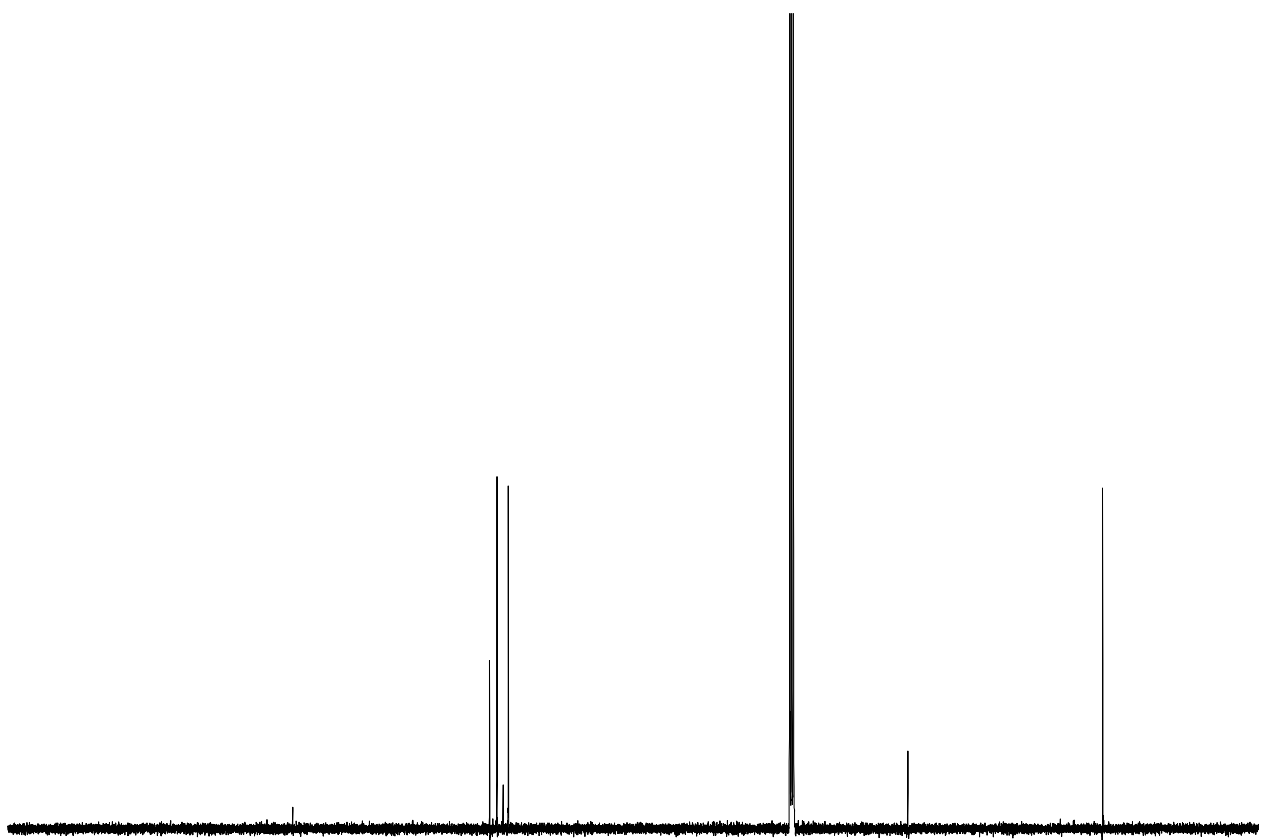

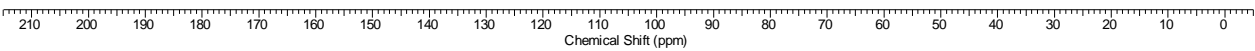

${ }^{13} \mathrm{C}$ NMR $\left(\mathrm{CDCl}_{3}, 25{ }^{\circ} \mathrm{C}\right)$ 


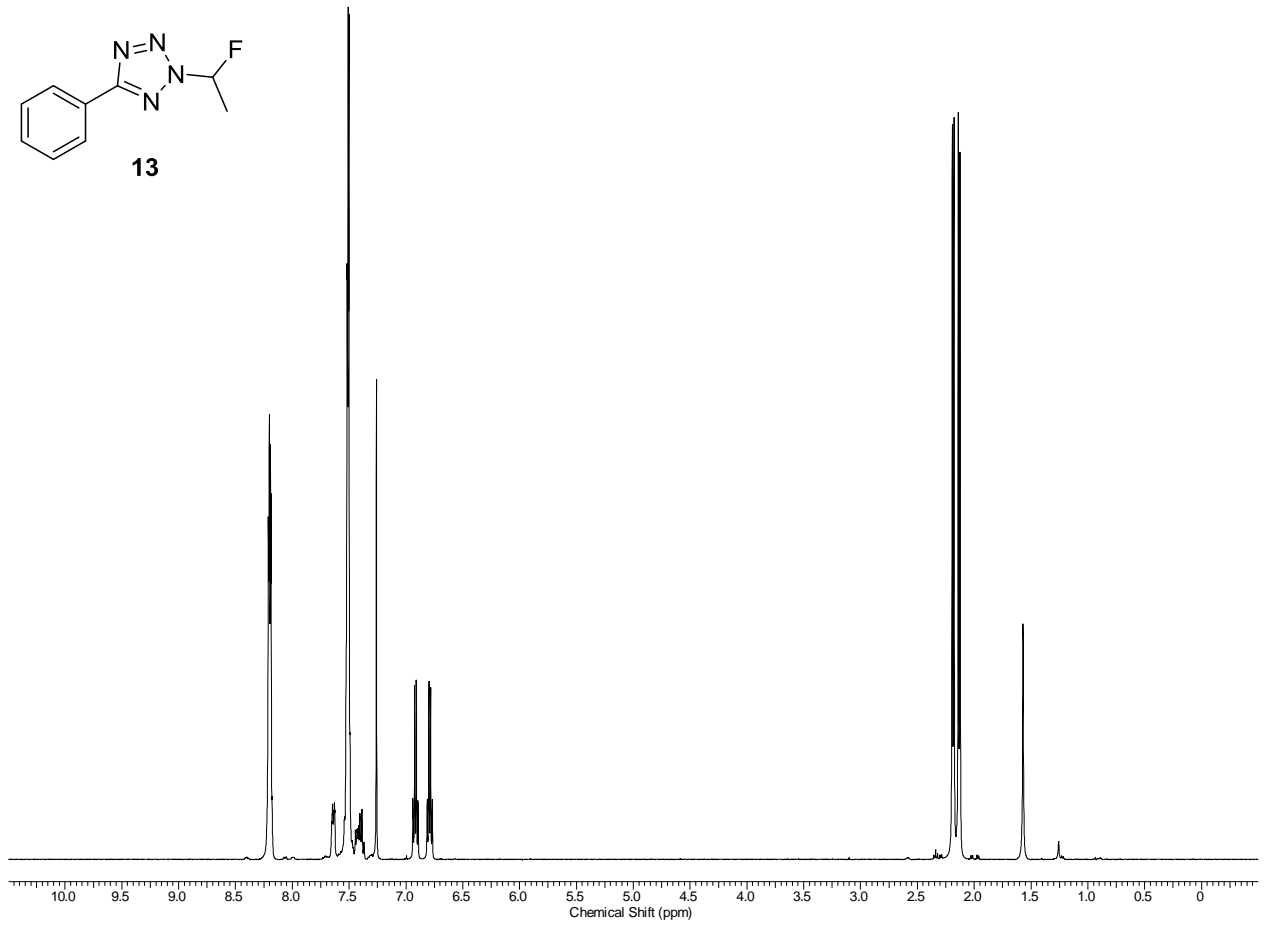

${ }^{1} \mathrm{H} \operatorname{NMR}\left(\mathrm{CDCl}_{3}, 25{ }^{\circ} \mathrm{C}\right)$

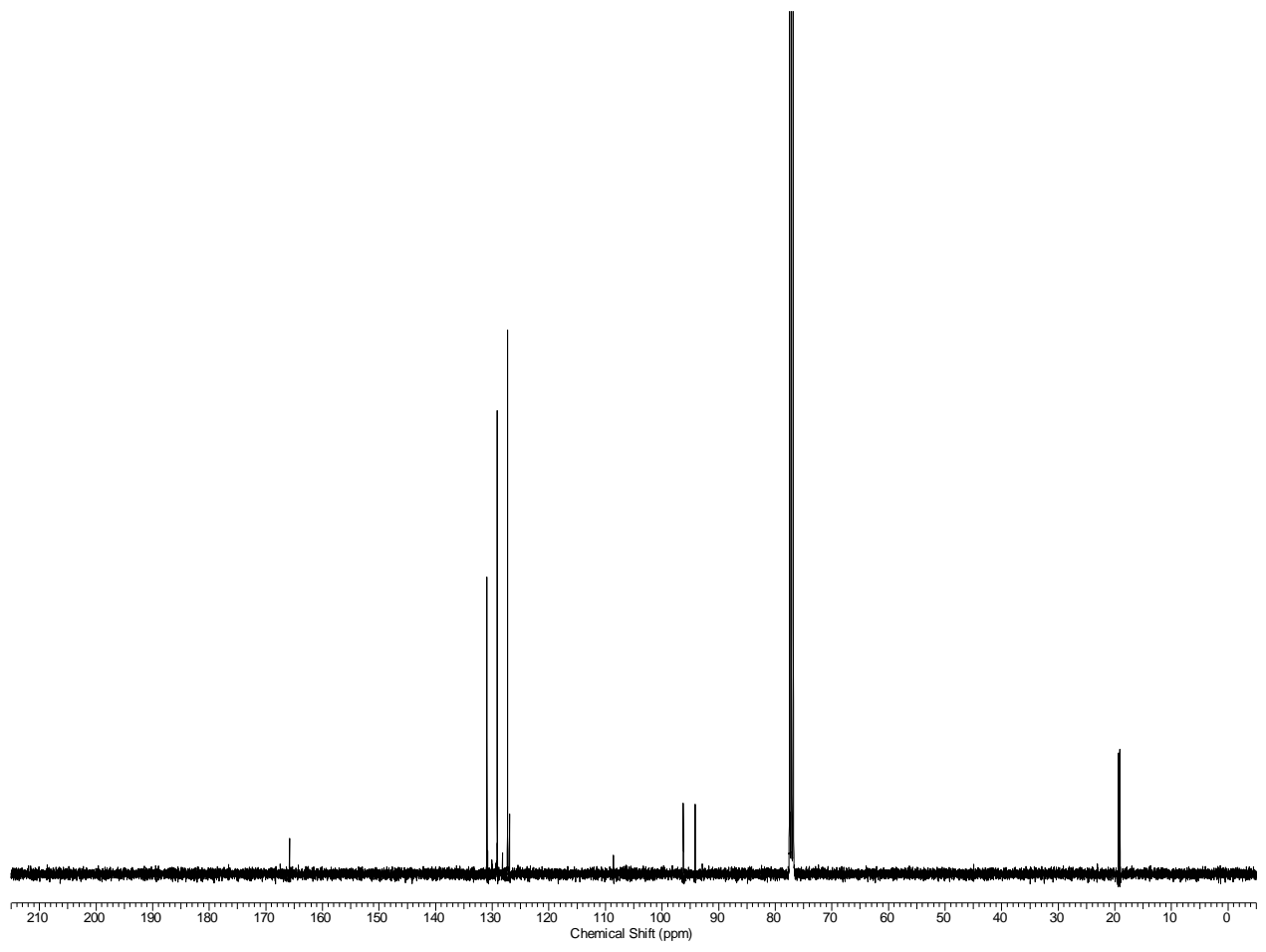

${ }^{13} \mathrm{C}$ NMR $\left(\mathrm{CDCl}_{3}, 25{ }^{\circ} \mathrm{C}\right)$ 

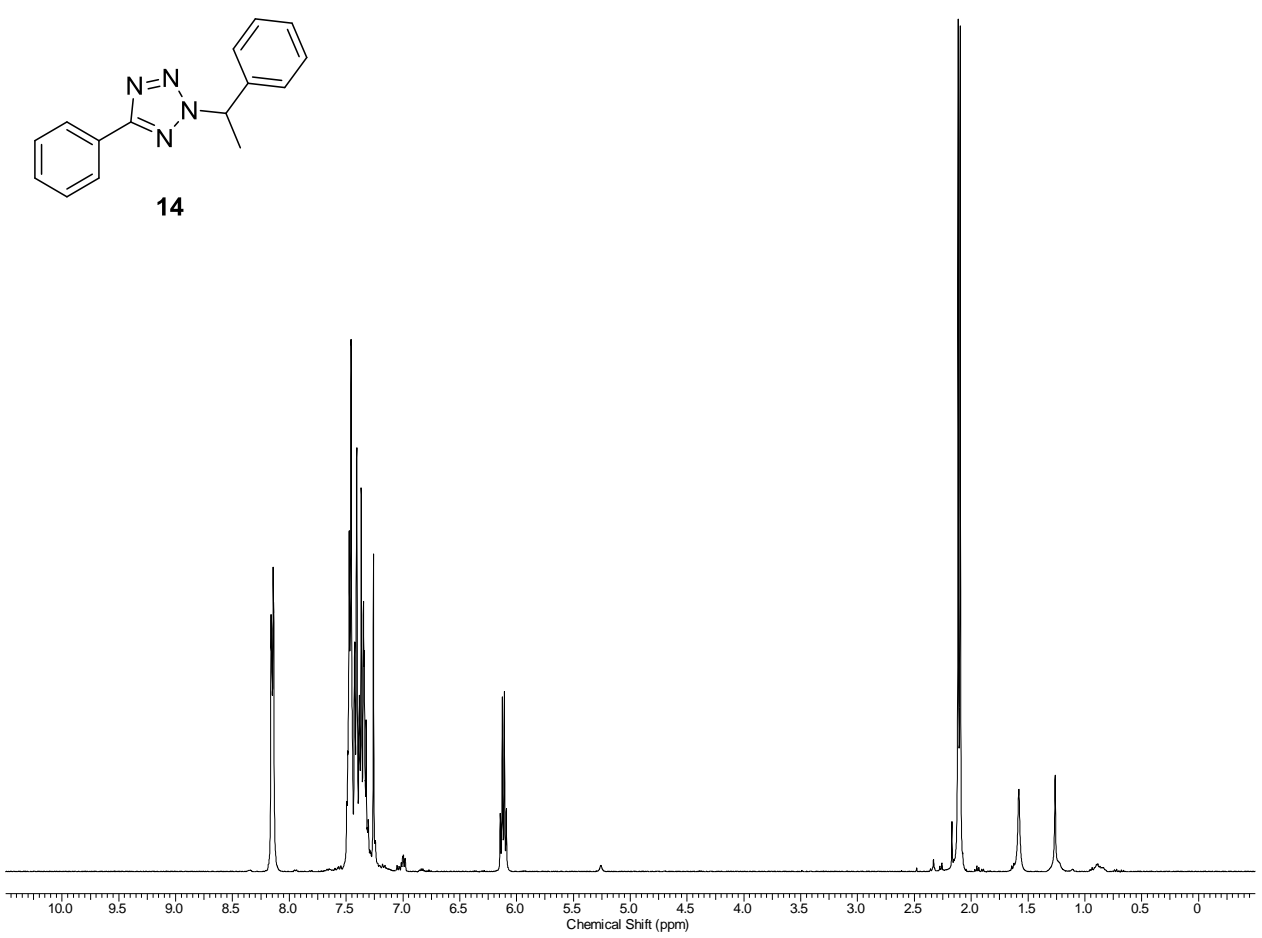

${ }^{1} \mathrm{H} \operatorname{NMR}\left(\mathrm{CDCl}_{3}, 25{ }^{\circ} \mathrm{C}\right)$

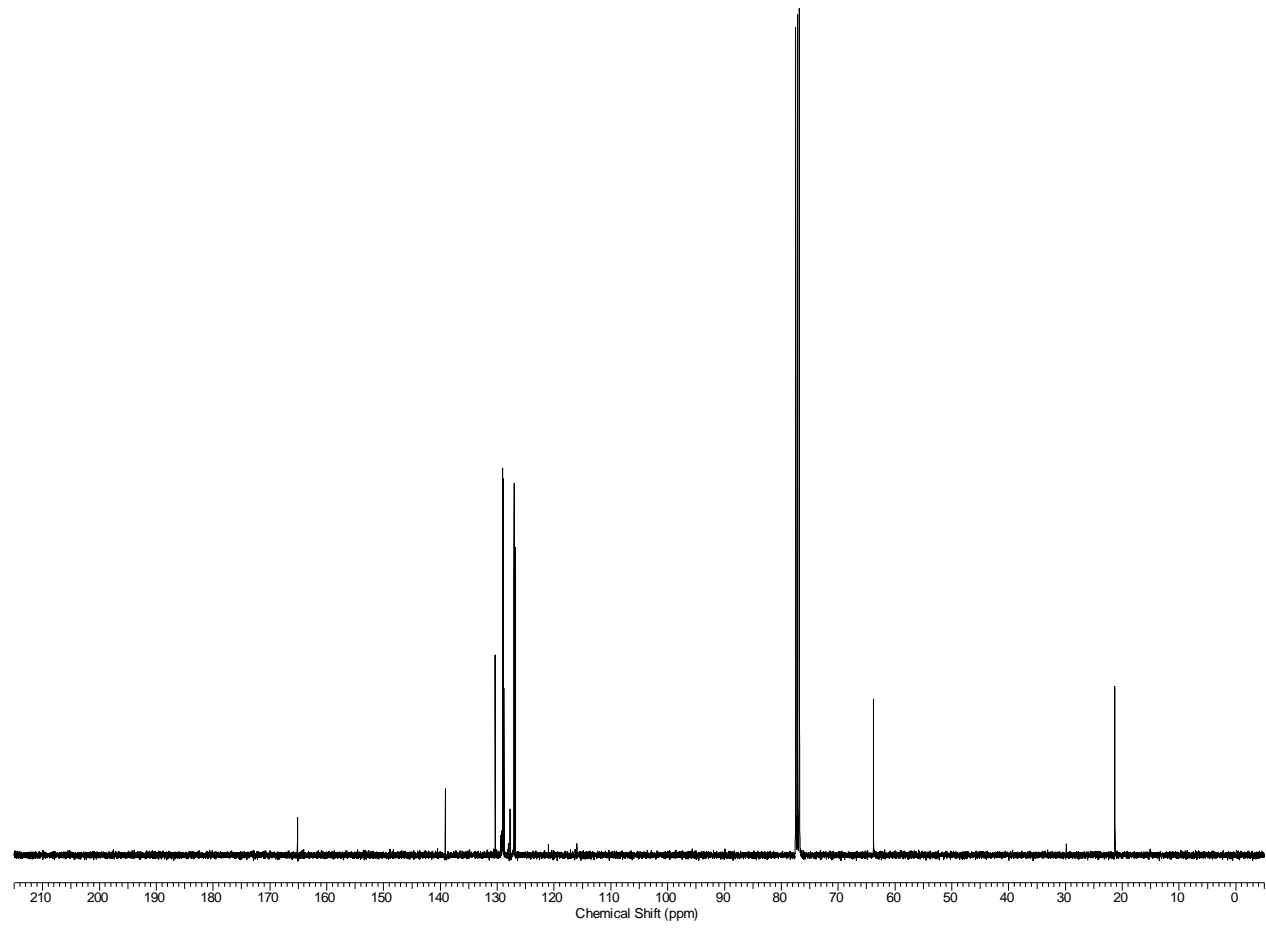

${ }^{13} \mathrm{C}$ NMR $\left(\mathrm{CDCl}_{3}, 25{ }^{\circ} \mathrm{C}\right)$ 


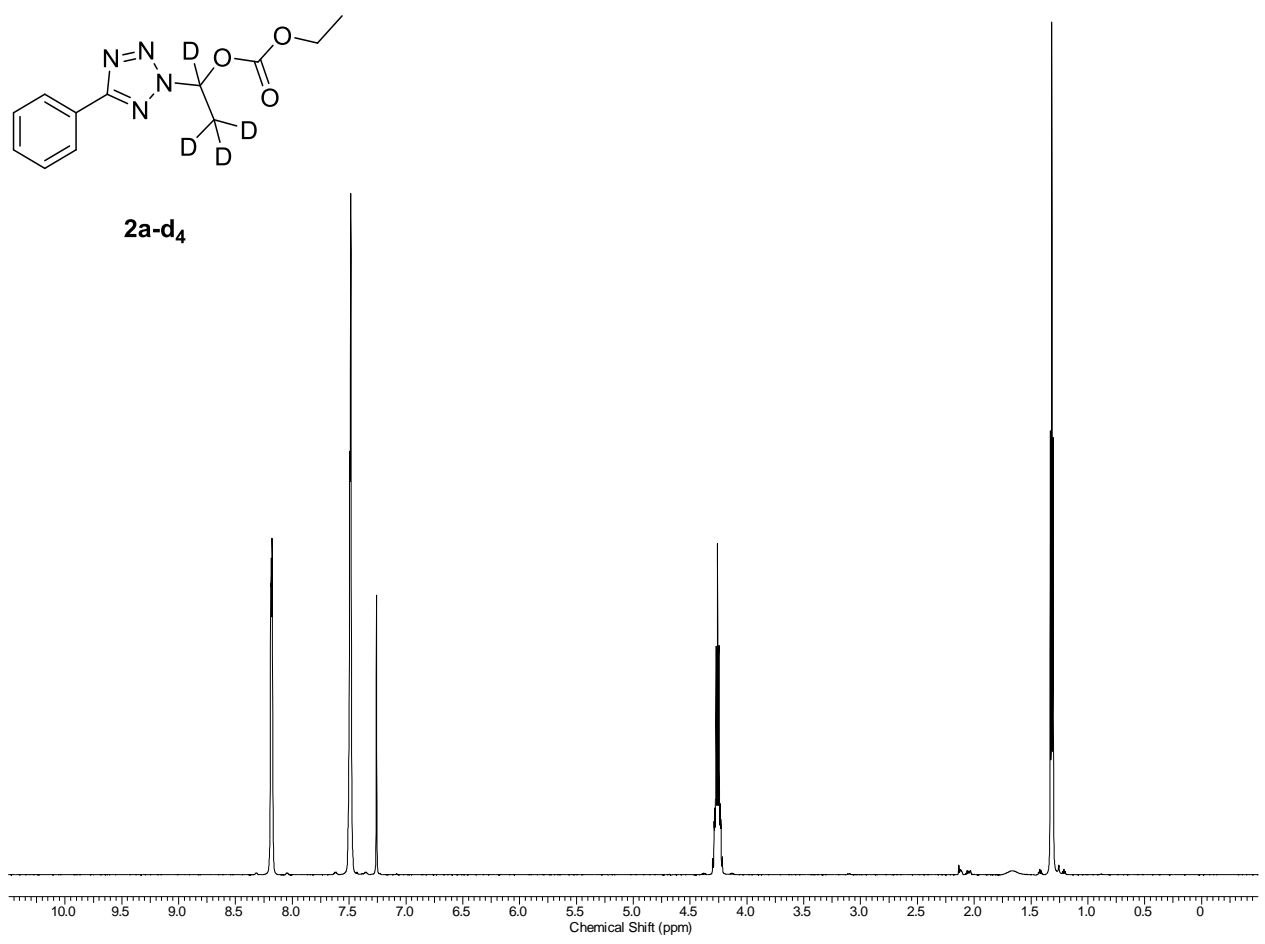

${ }^{1} \mathrm{H} \operatorname{NMR}\left(\mathrm{CDCl}_{3}, 25{ }^{\circ} \mathrm{C}\right)$

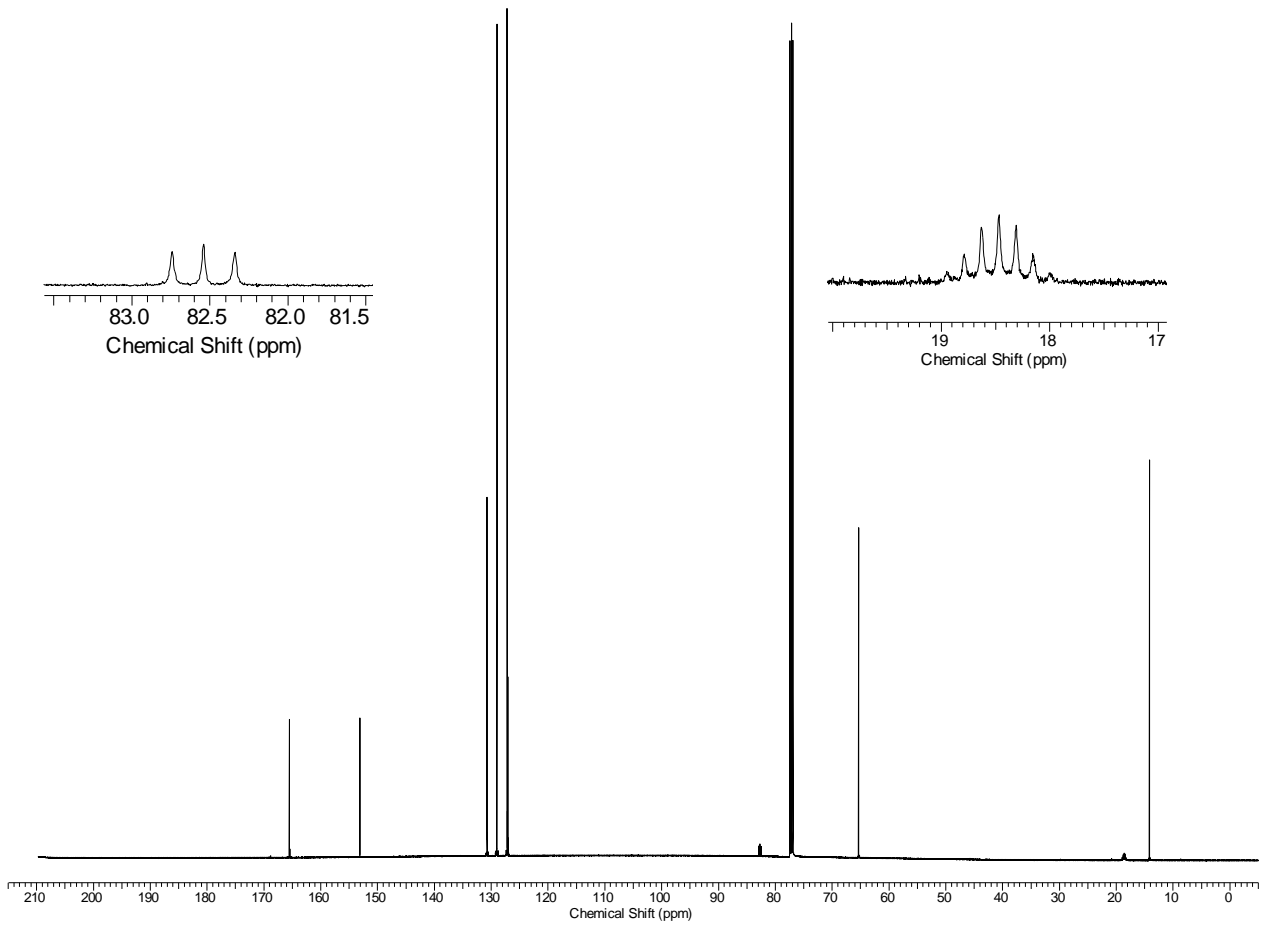

${ }^{13} \mathrm{C}$ NMR $\left(\mathrm{CDCl}_{3}, 25{ }^{\circ} \mathrm{C}\right)$ 


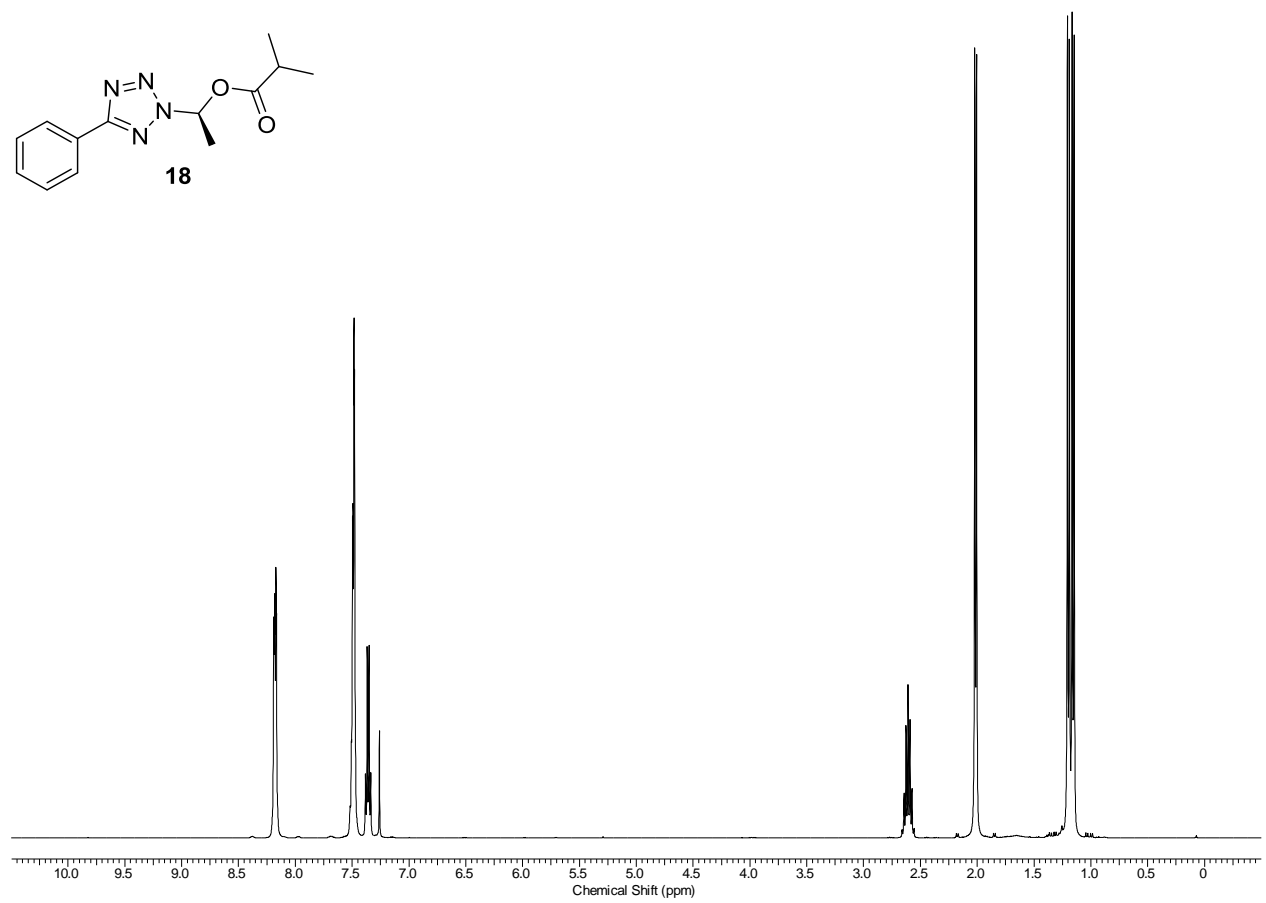

${ }^{1} \mathrm{H}$ NMR $\left(\mathrm{CDCl}_{3}, 25^{\circ} \mathrm{C}\right)$

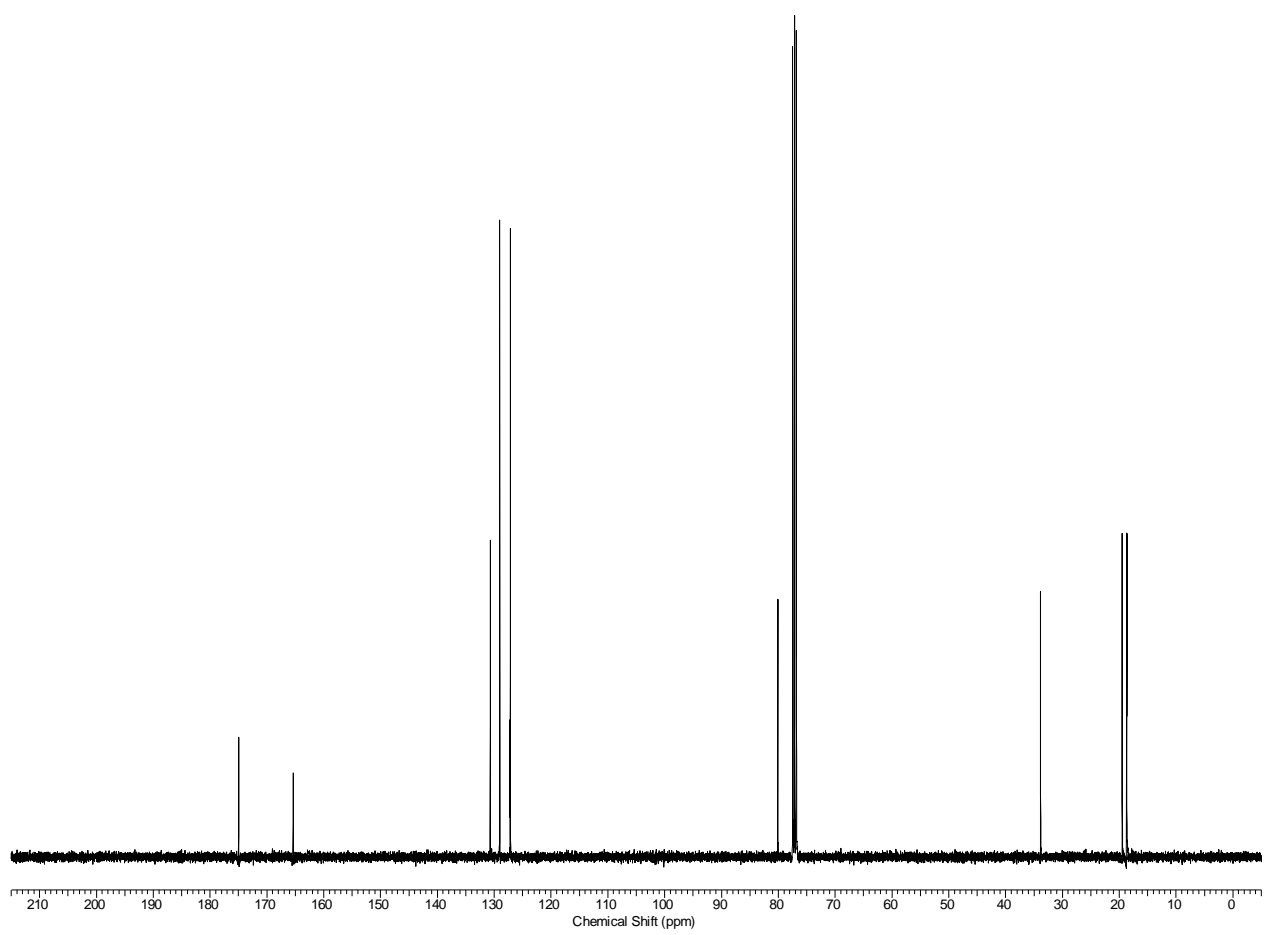

${ }^{13} \mathrm{C}$ NMR $\left(\mathrm{CDCl}_{3}, 25{ }^{\circ} \mathrm{C}\right)$ 


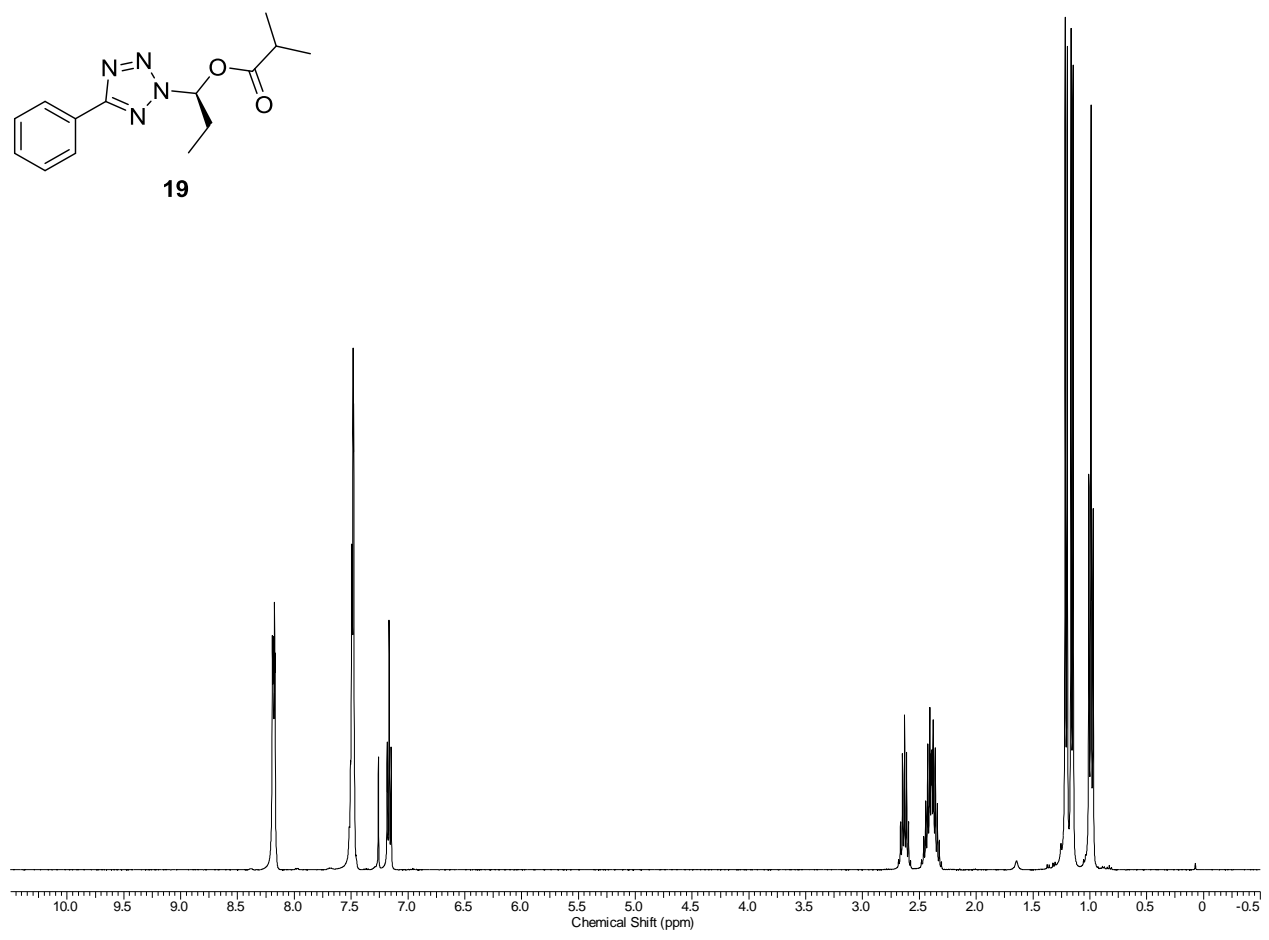

${ }^{1} \mathrm{H} \operatorname{NMR}\left(\mathrm{CDCl}_{3}, 25{ }^{\circ} \mathrm{C}\right)$

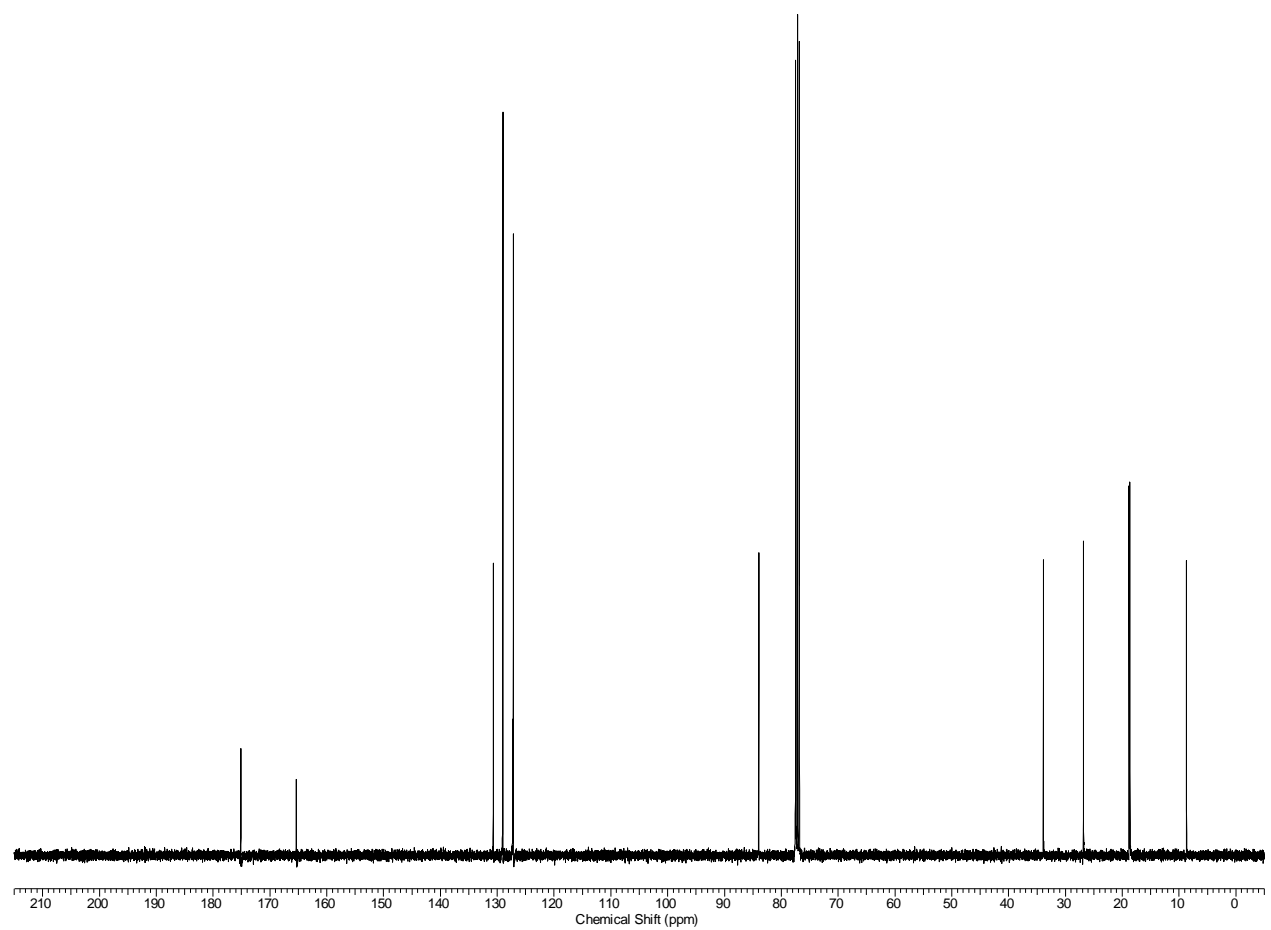

${ }^{13} \mathrm{C}$ NMR $\left(\mathrm{CDCl}_{3}, 25{ }^{\circ} \mathrm{C}\right)$ 


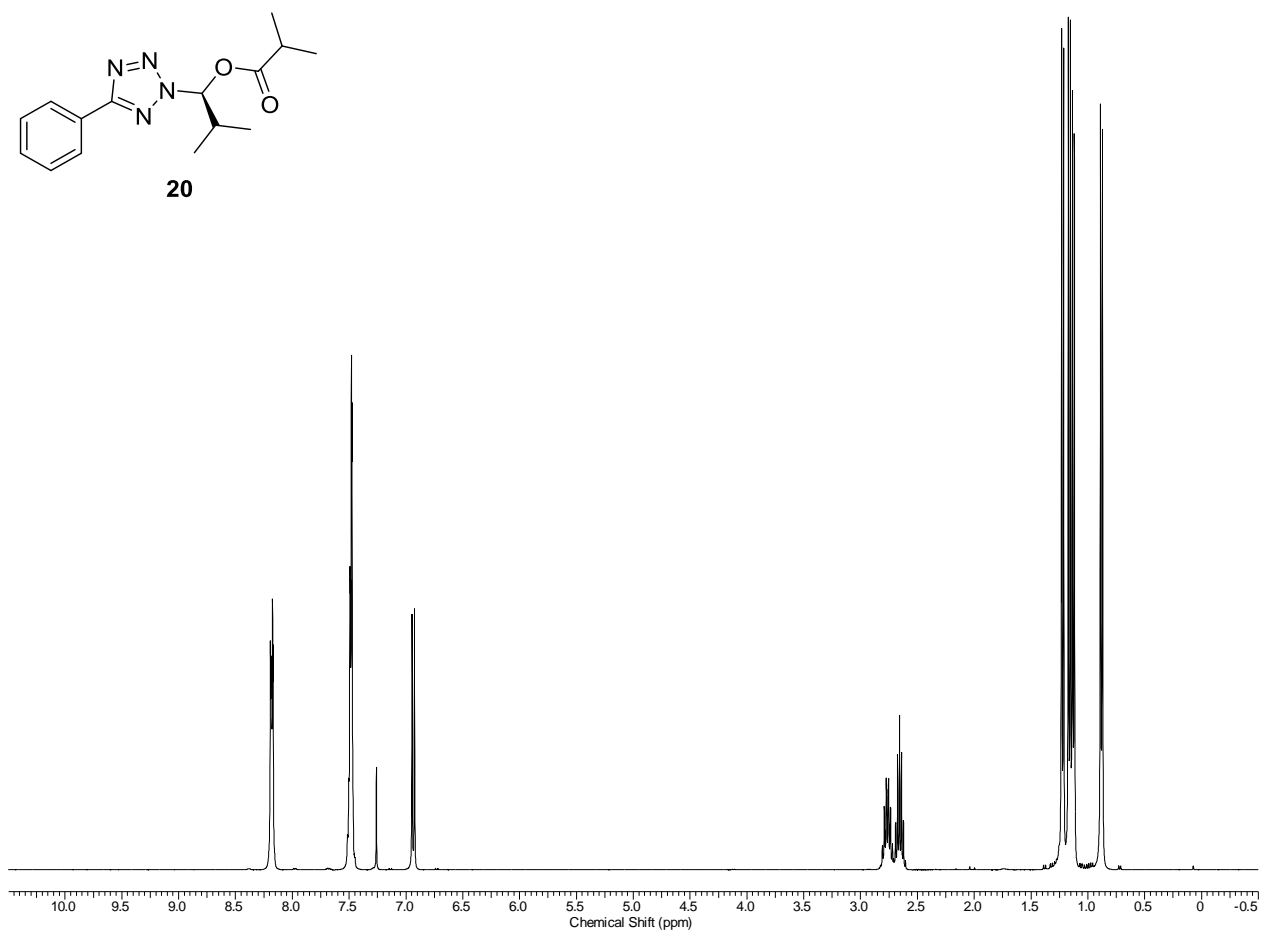

${ }^{1} \mathrm{H} \operatorname{NMR}\left(\mathrm{CDCl}_{3}, 25{ }^{\circ} \mathrm{C}\right)$

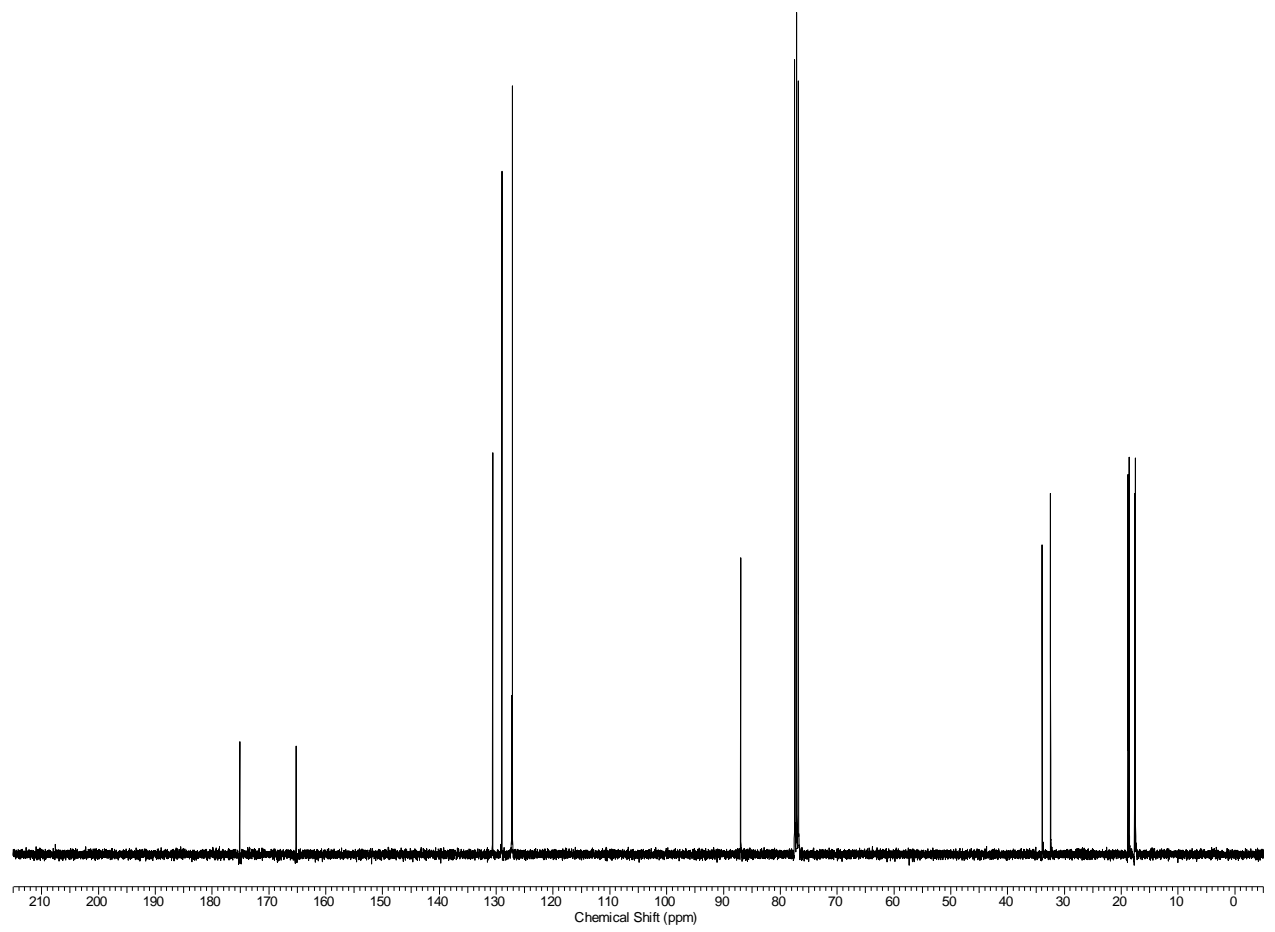

${ }^{13} \mathrm{C}$ NMR $\left(\mathrm{CDCl}_{3}, 25{ }^{\circ} \mathrm{C}\right)$ 


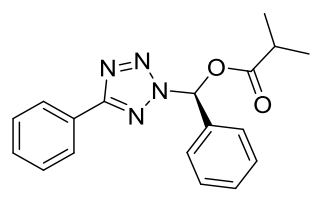

21

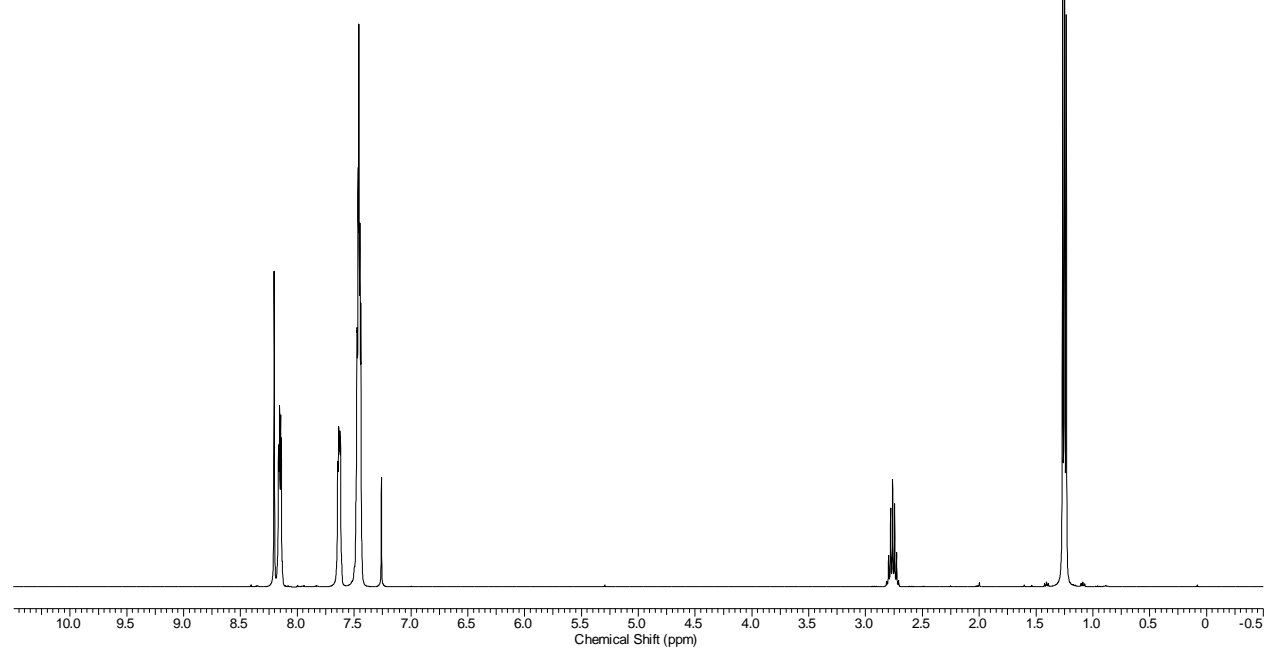

${ }^{1} \mathrm{H} \operatorname{NMR}\left(\mathrm{CDCl}_{3}, 25{ }^{\circ} \mathrm{C}\right)$

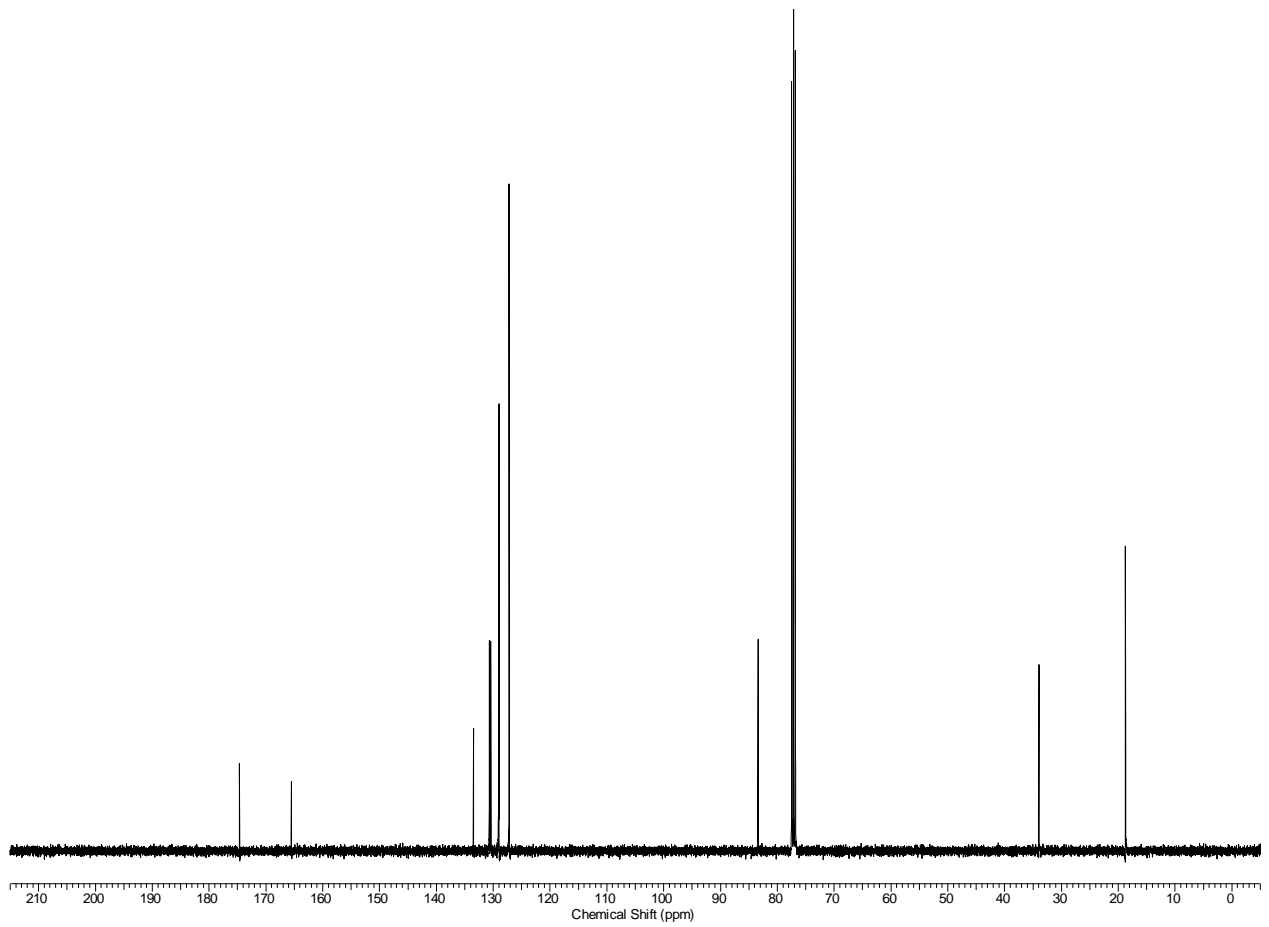

${ }^{13} \mathrm{C}$ NMR $\left(\mathrm{CDCl}_{3}, 25{ }^{\circ} \mathrm{C}\right)$ 


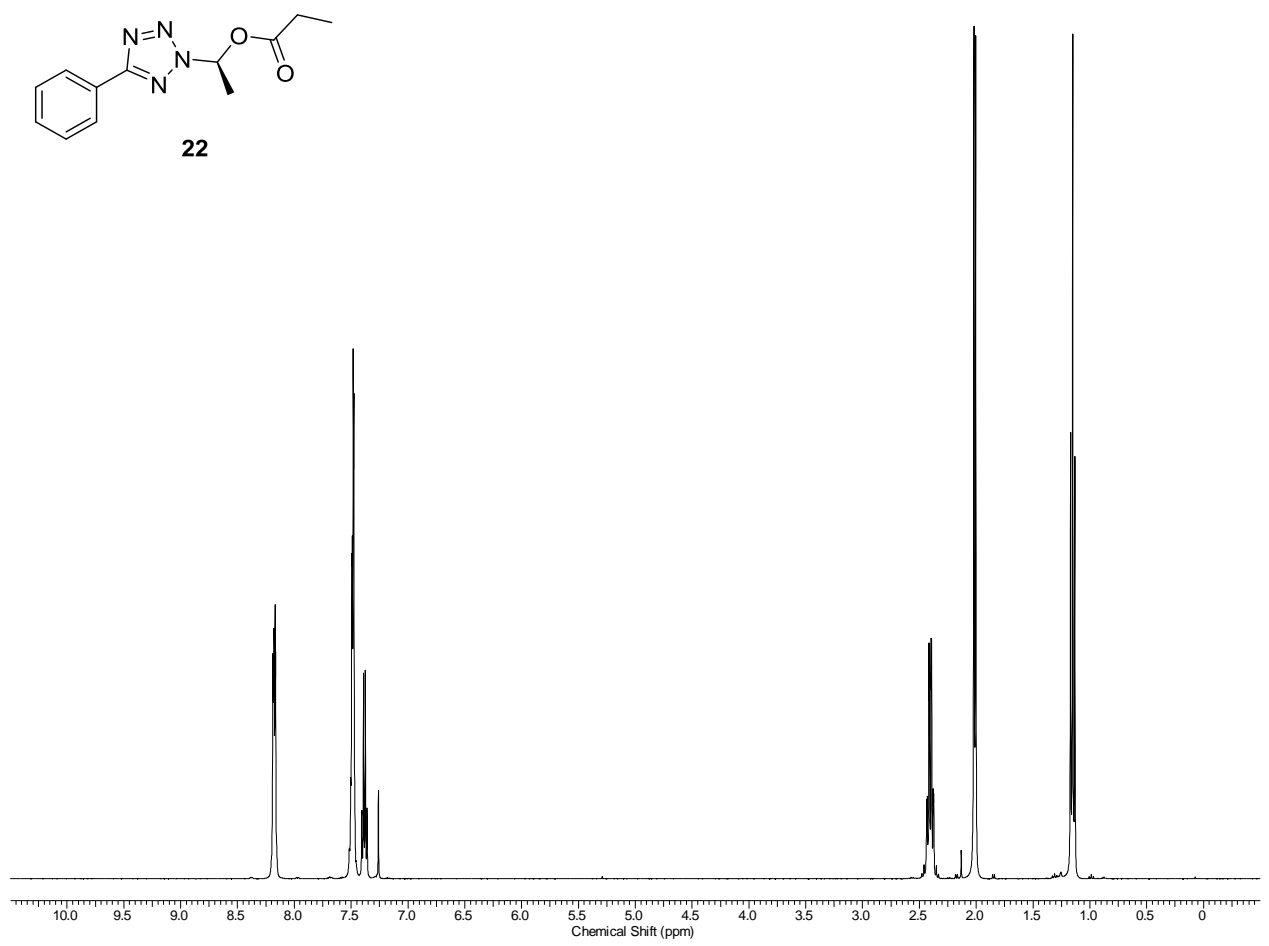

${ }^{1} \mathrm{H} \operatorname{NMR}\left(\mathrm{CDCl}_{3}, 25{ }^{\circ} \mathrm{C}\right)$

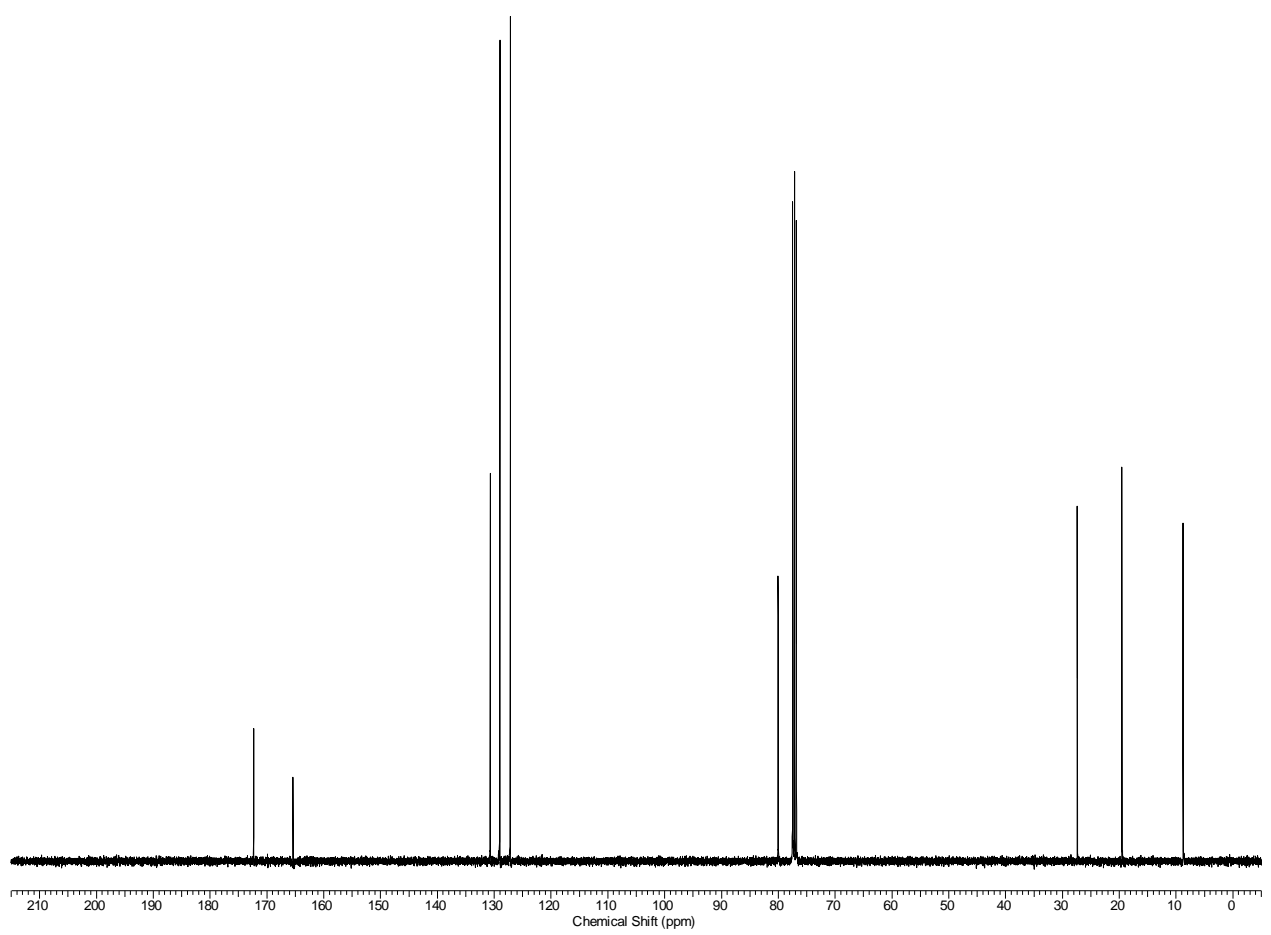

${ }^{13} \mathrm{C}$ NMR $\left(\mathrm{CDCl}_{3}, 25{ }^{\circ} \mathrm{C}\right)$ 


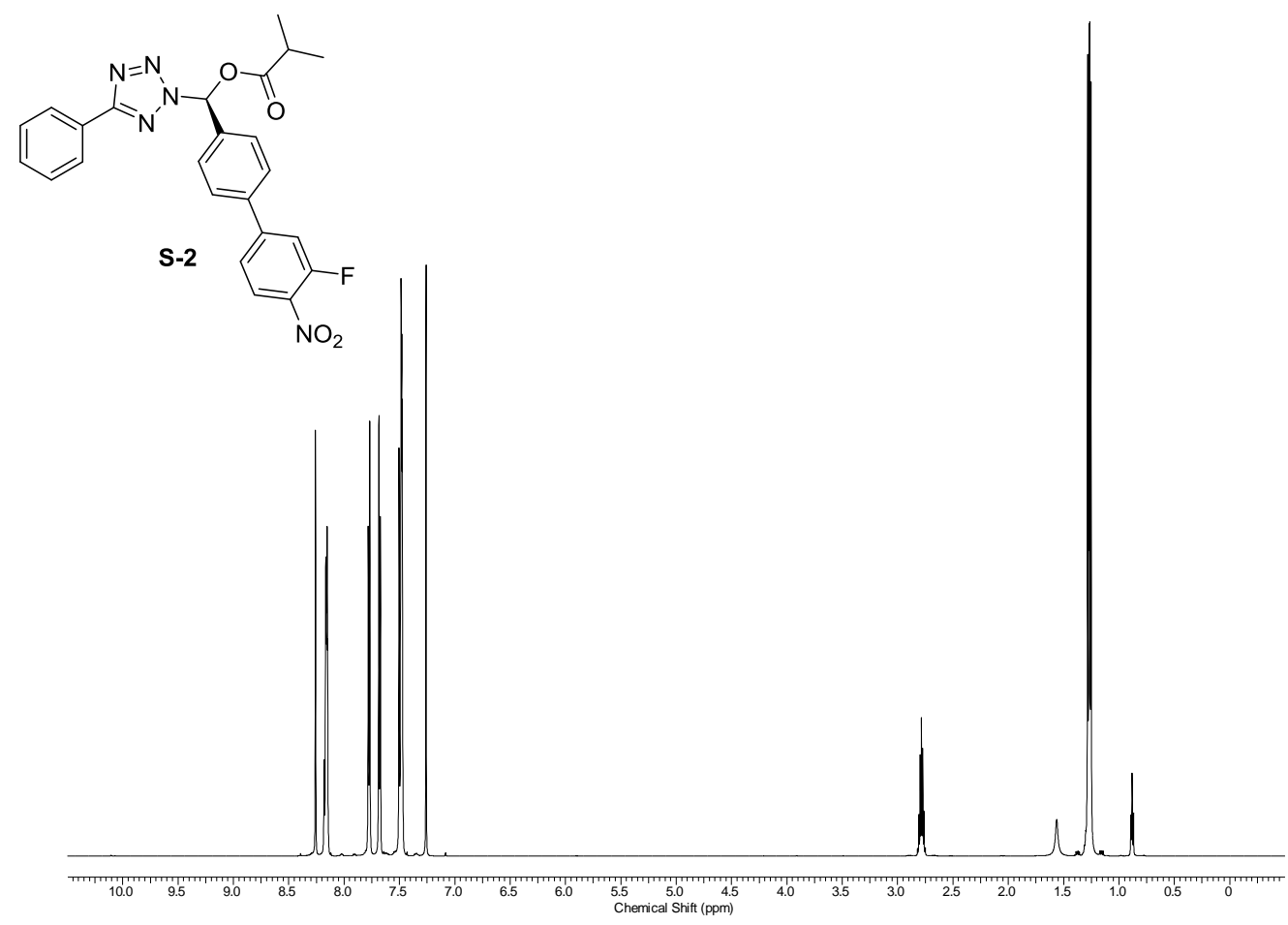

${ }^{1} \mathrm{H} \operatorname{NMR}\left(\mathrm{CDCl}_{3}, 25^{\circ} \mathrm{C}\right)$

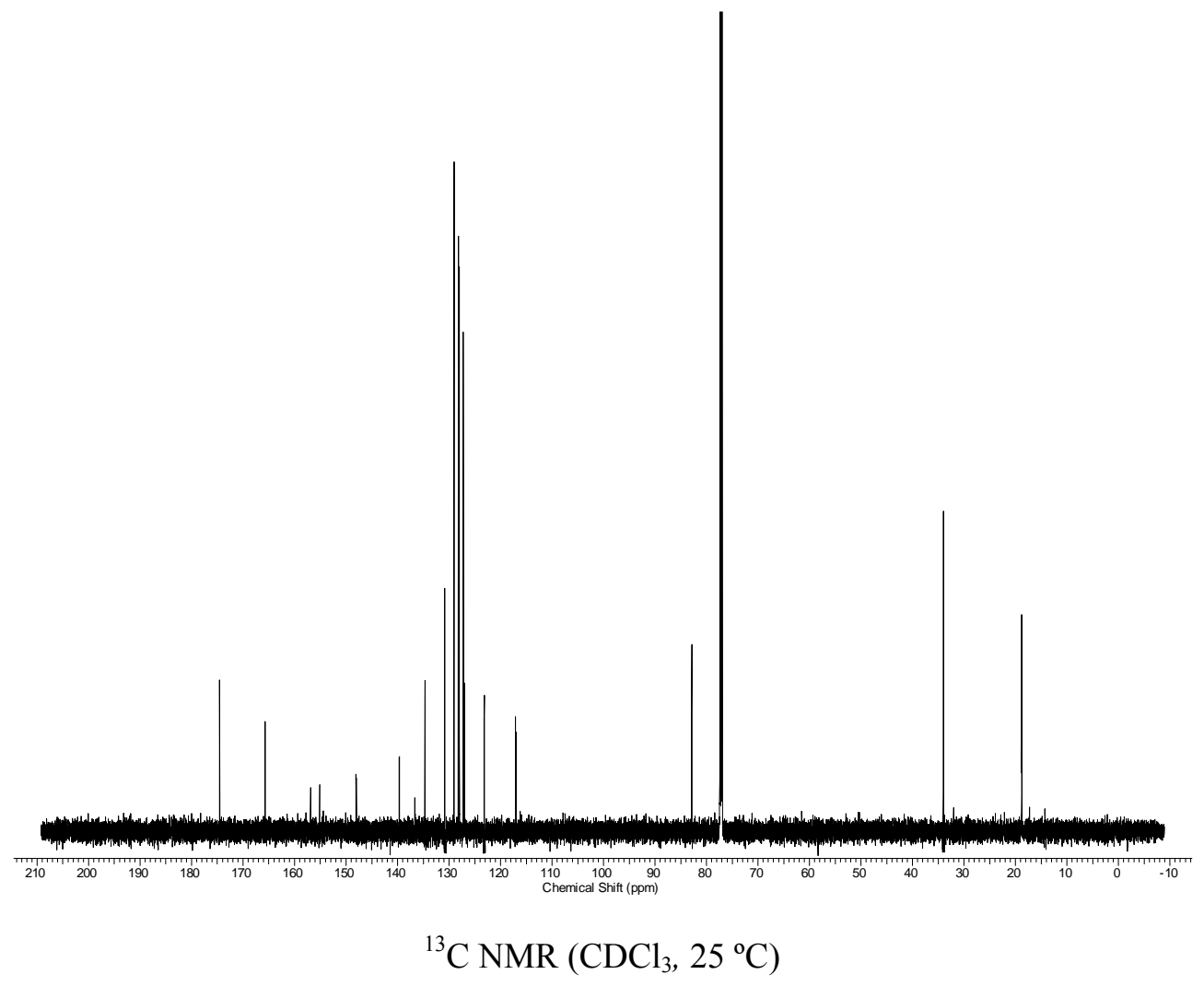




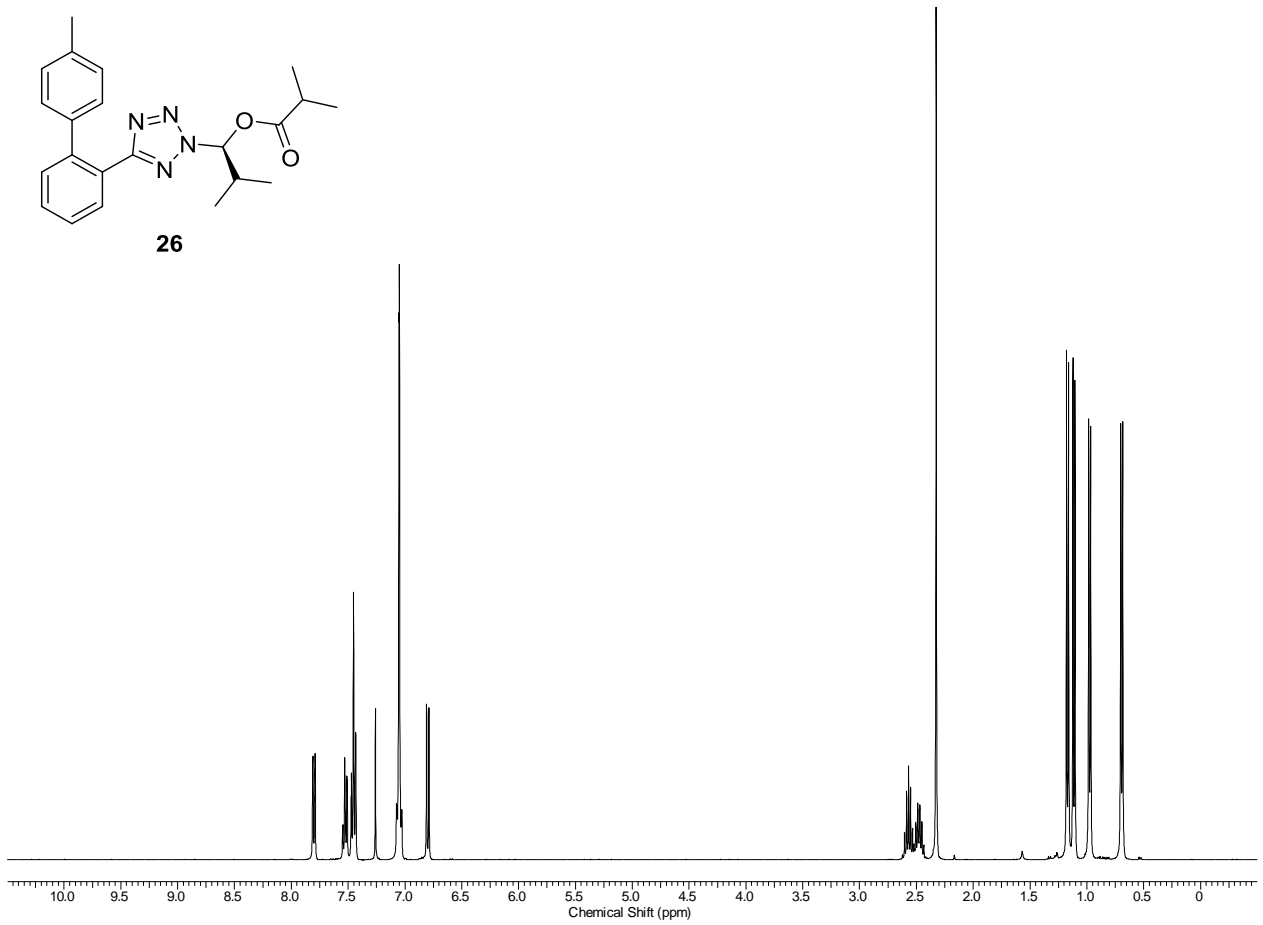

${ }^{1} \mathrm{H} \operatorname{NMR}\left(\mathrm{CDCl}_{3}, 25{ }^{\circ} \mathrm{C}\right)$

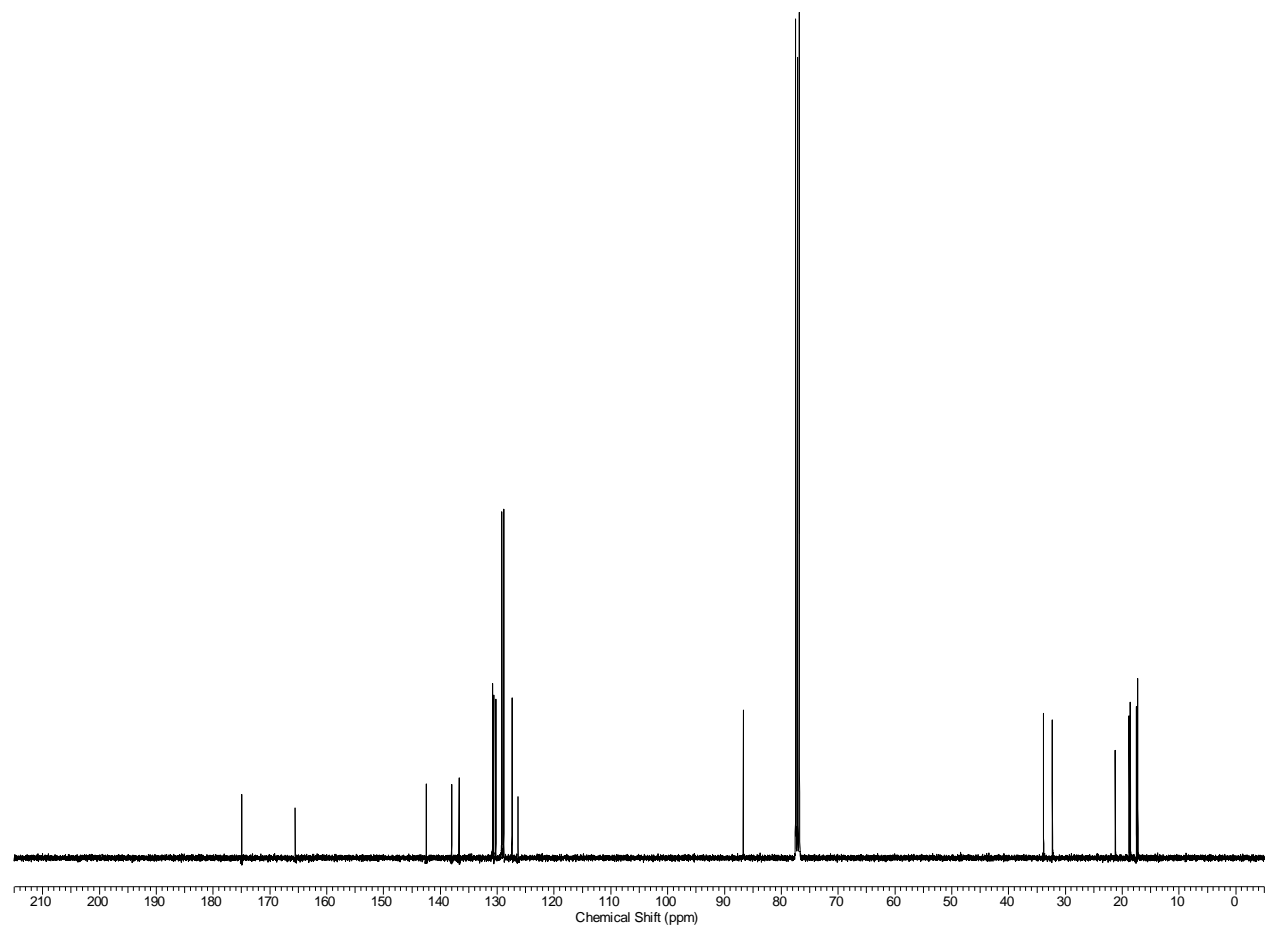

${ }^{13} \mathrm{C}$ NMR $\left(\mathrm{CDCl}_{3}, 25{ }^{\circ} \mathrm{C}\right)$ 

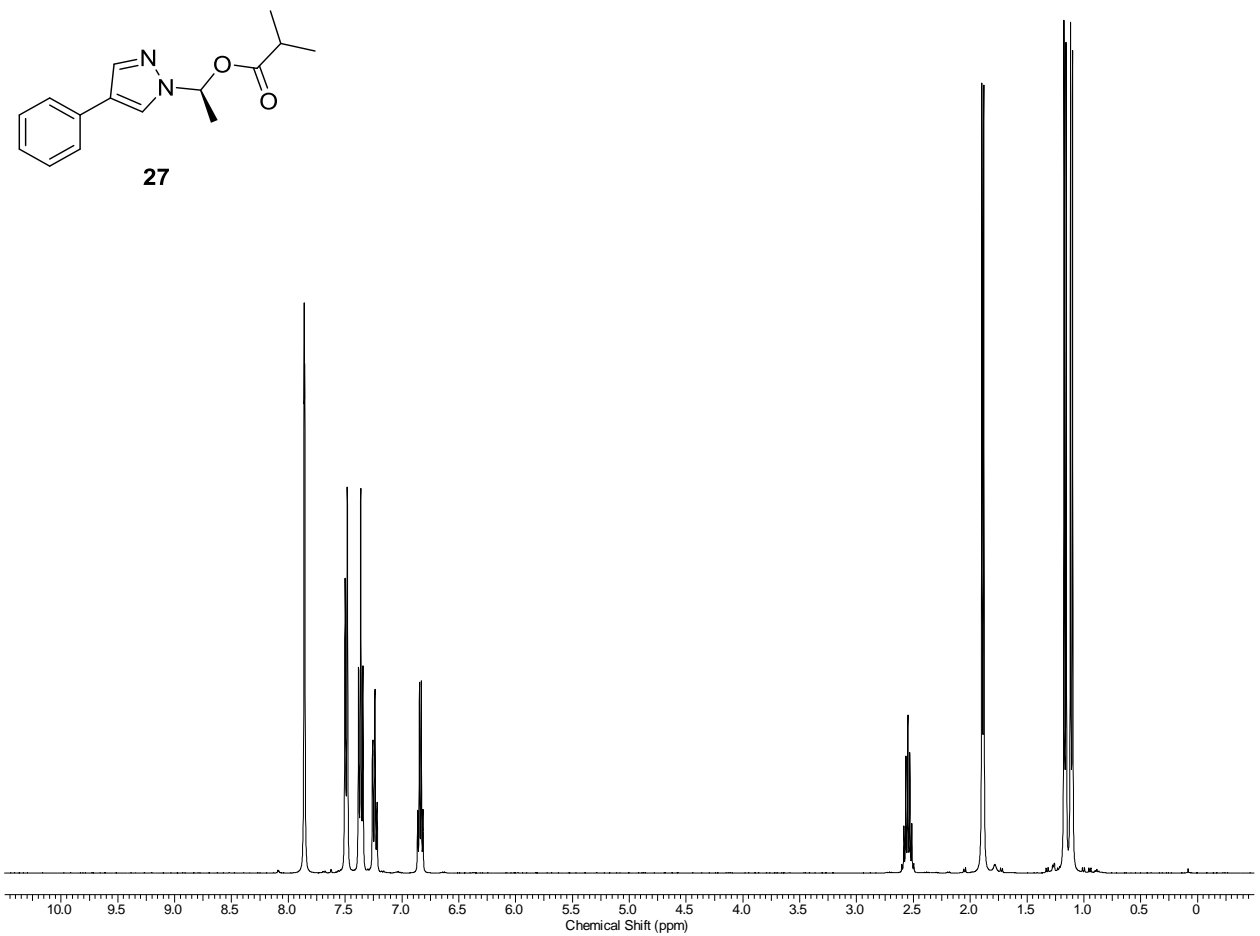

${ }^{1} \mathrm{H} \operatorname{NMR}\left(\mathrm{CDCl}_{3}, 25{ }^{\circ} \mathrm{C}\right)$

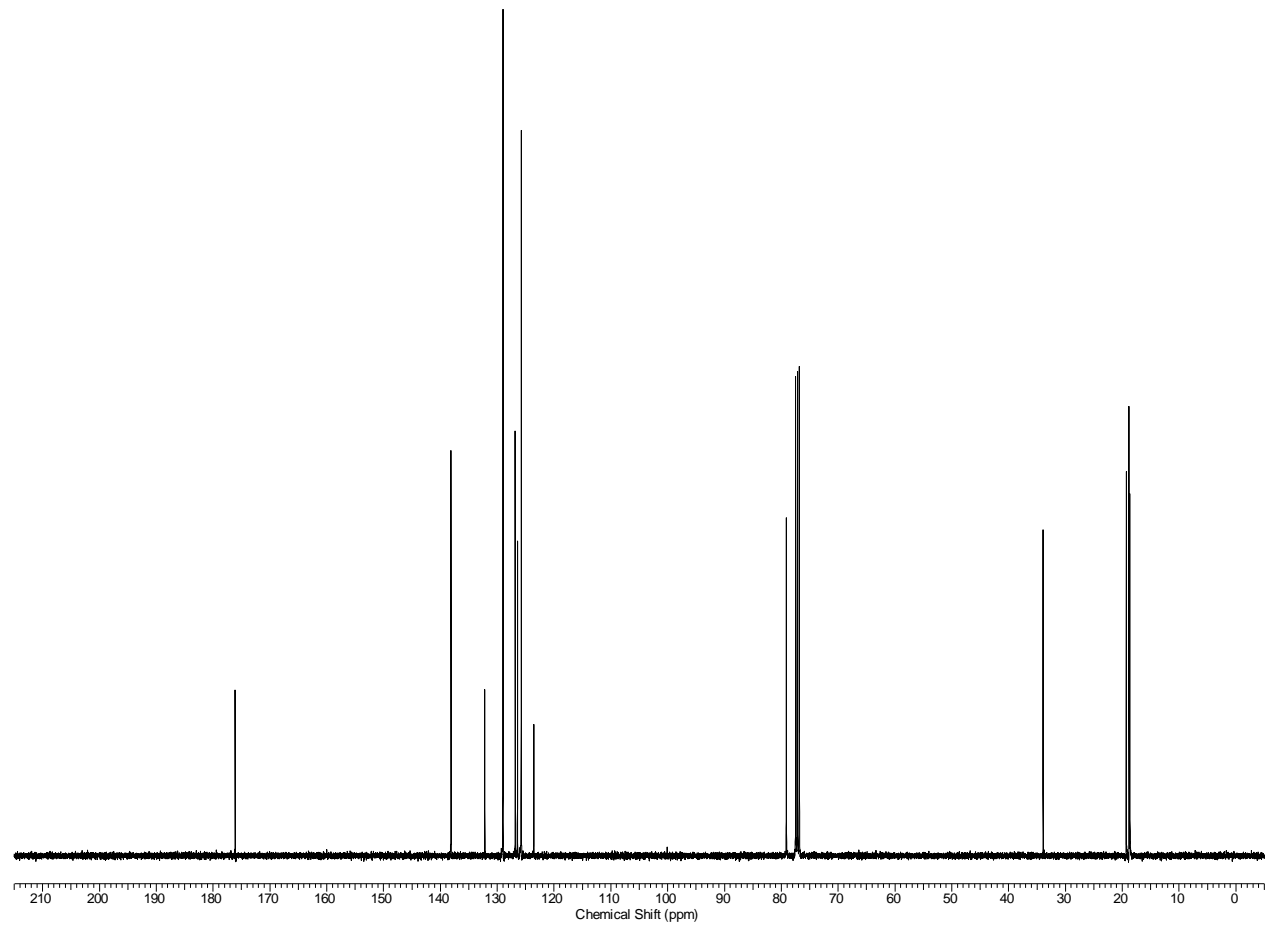

${ }^{13} \mathrm{C}$ NMR $\left(\mathrm{CDCl}_{3}, 25{ }^{\circ} \mathrm{C}\right)$ 


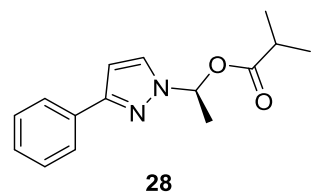

28

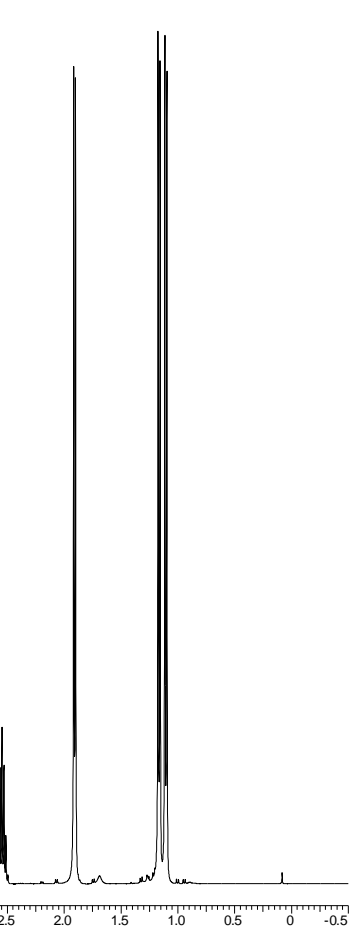

${ }^{1} \mathrm{H} \operatorname{NMR}\left(\mathrm{CDCl}_{3}, 25{ }^{\circ} \mathrm{C}\right)$

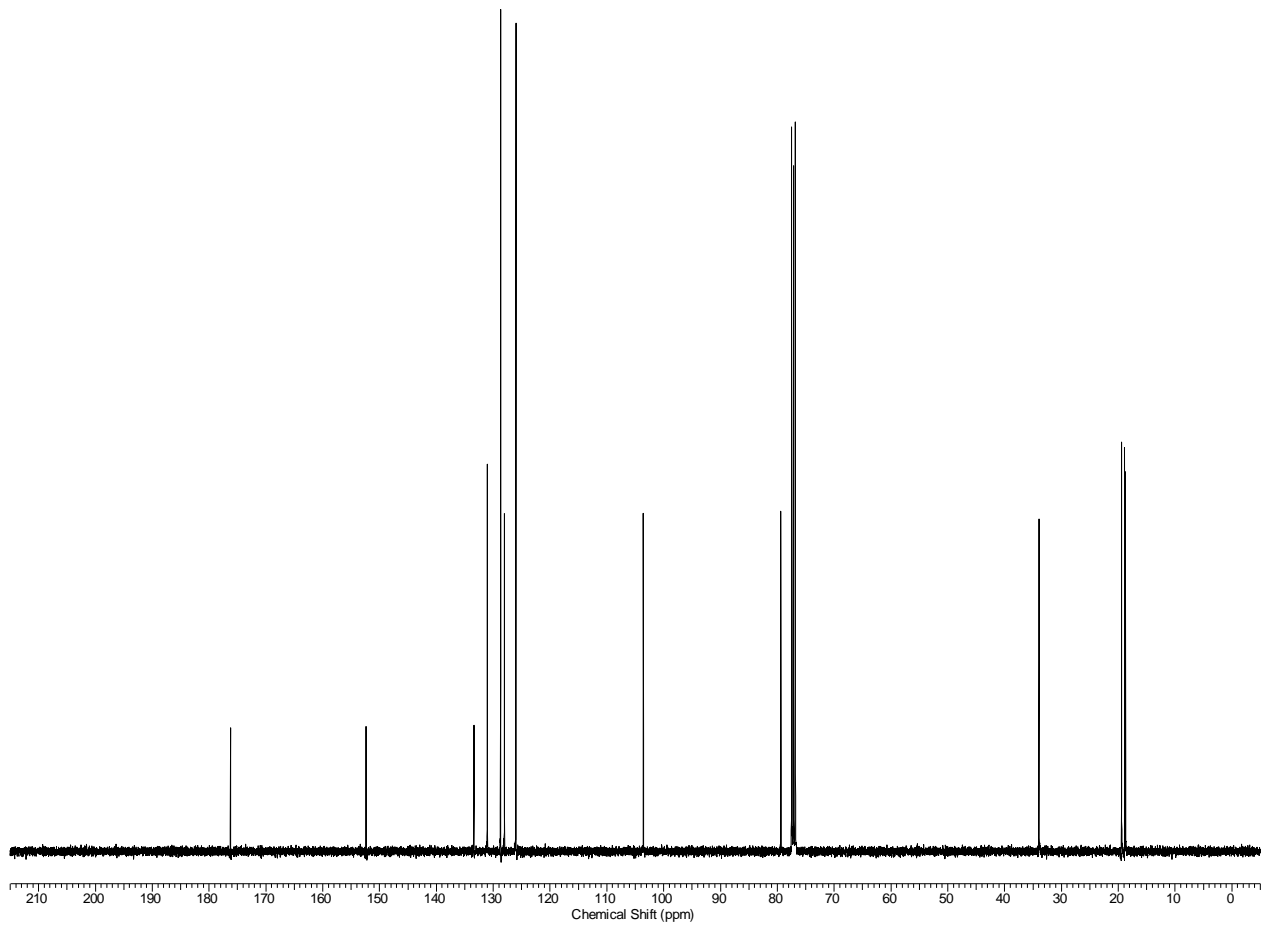

${ }^{13} \mathrm{C}$ NMR $\left(\mathrm{CDCl}_{3}, 25{ }^{\circ} \mathrm{C}\right)$ 

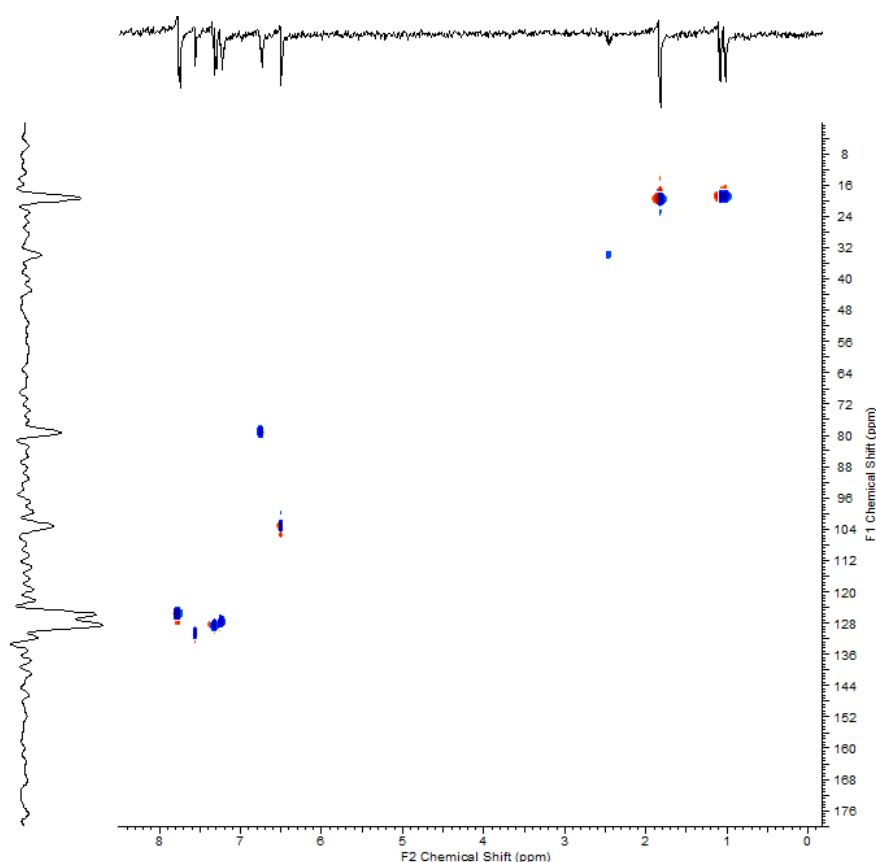

$\operatorname{HSQC}\left(\mathrm{CDCl}_{3}, 25^{\circ} \mathrm{C}\right)$

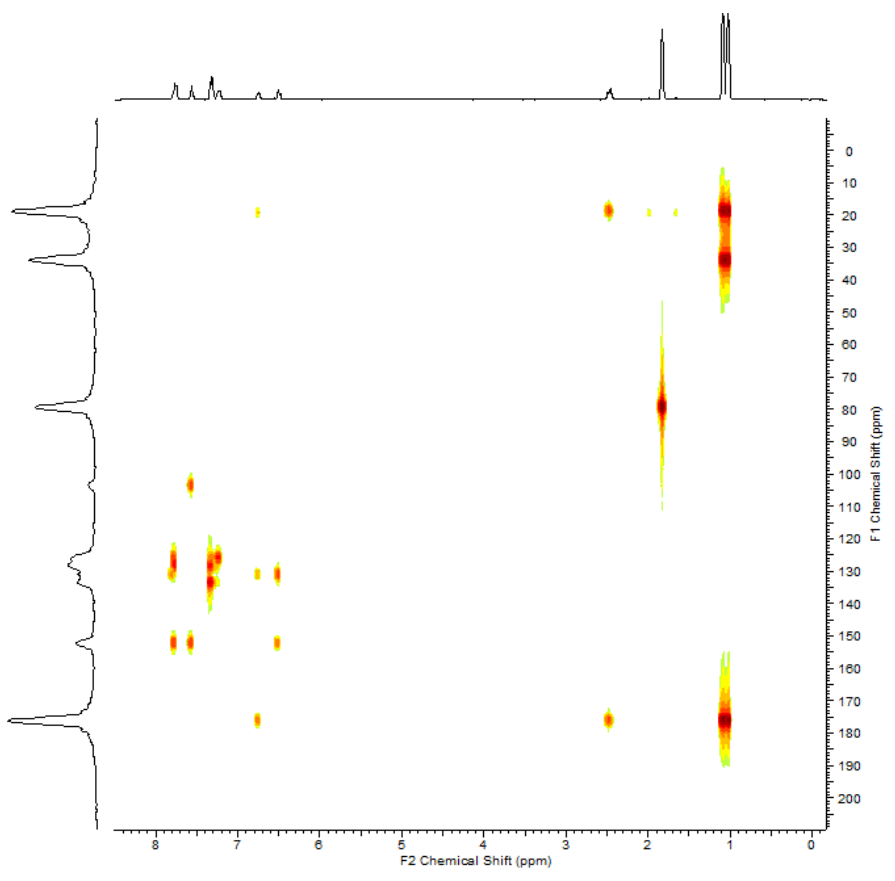

$\operatorname{HMBC}\left(\mathrm{CDCl}_{3}, 25^{\circ} \mathrm{C}\right)$ 


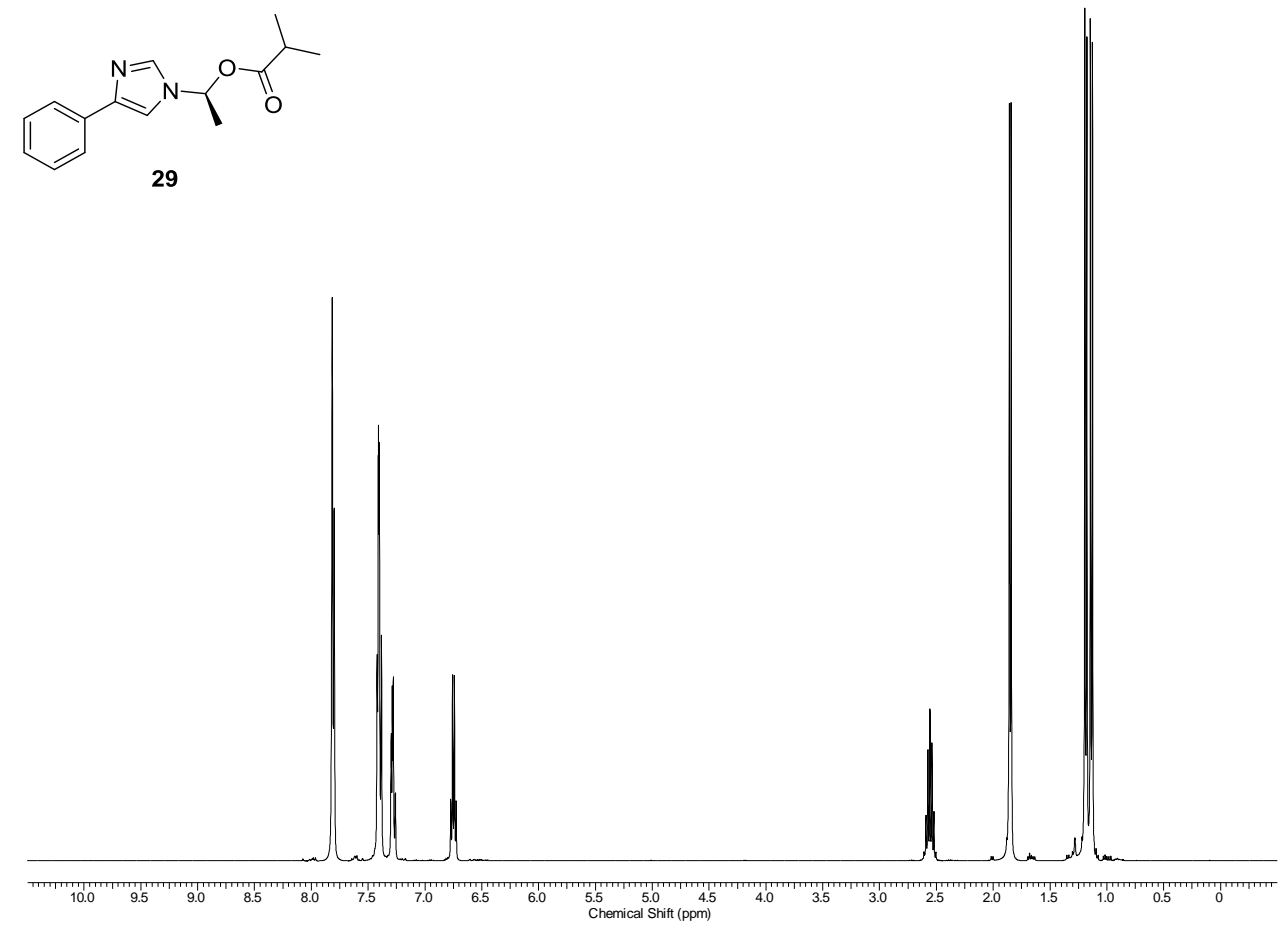

${ }^{1} \mathrm{H} \operatorname{NMR}\left(\mathrm{CDCl}_{3}, 25{ }^{\circ} \mathrm{C}\right)$

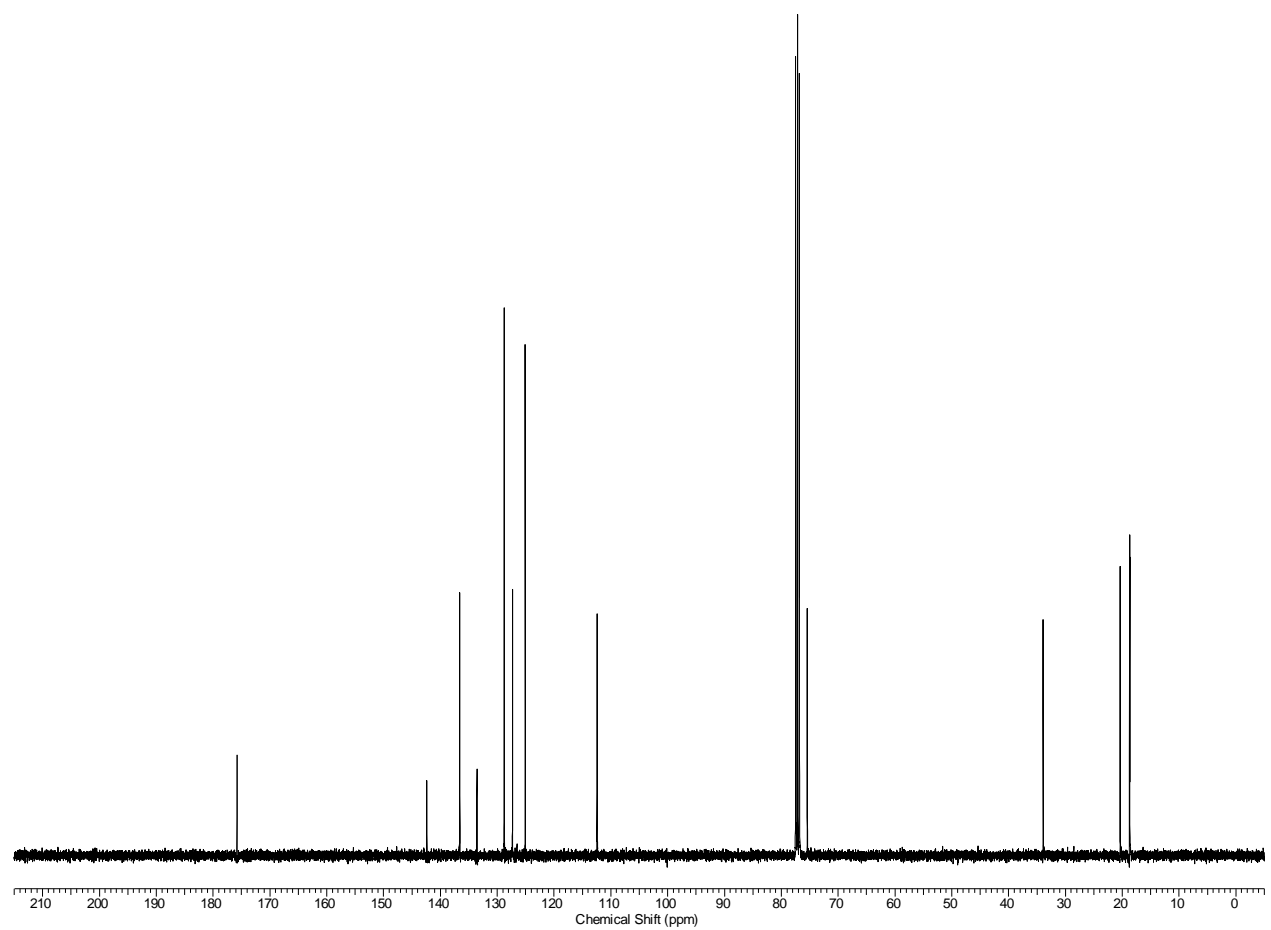

${ }^{13} \mathrm{C}$ NMR $\left(\mathrm{CDCl}_{3}, 25{ }^{\circ} \mathrm{C}\right)$ 


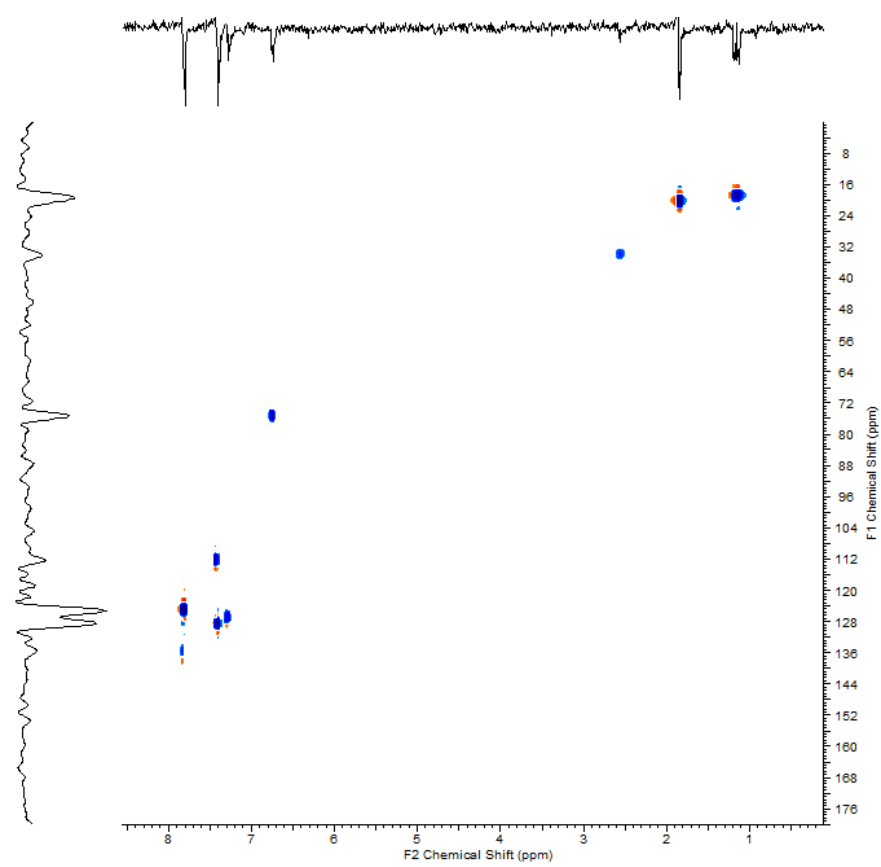

$\operatorname{HSQC}\left(\mathrm{CDCl}_{3}, 25^{\circ} \mathrm{C}\right)$

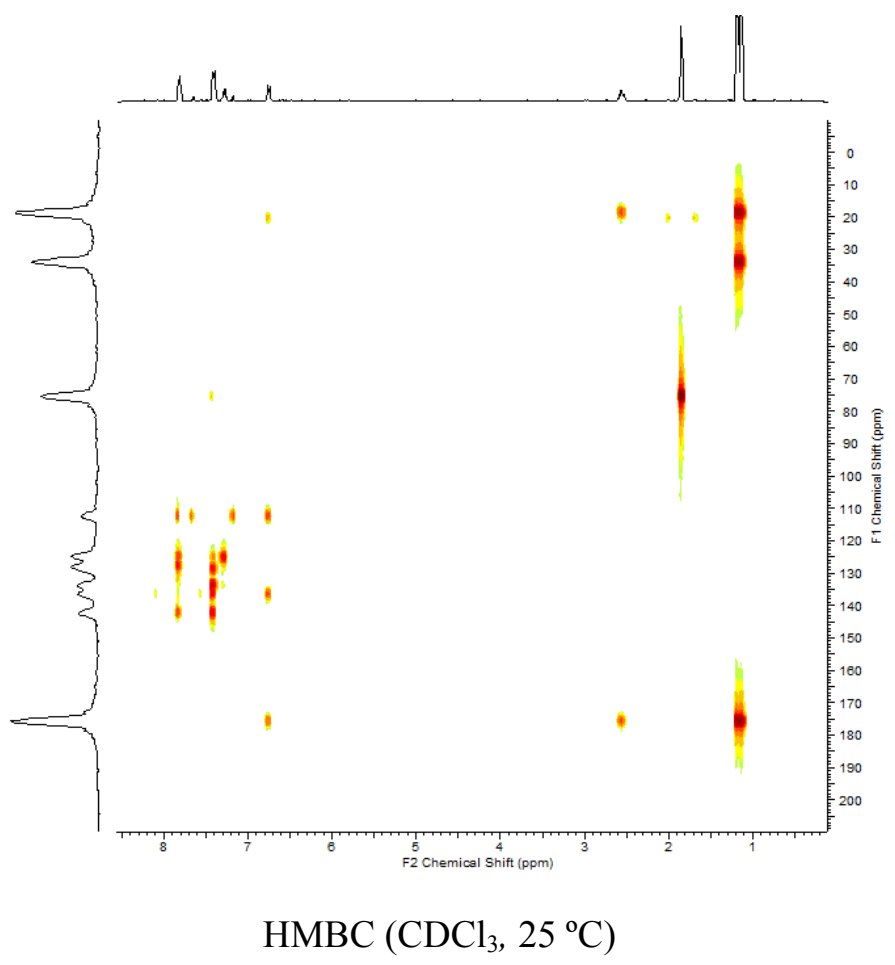




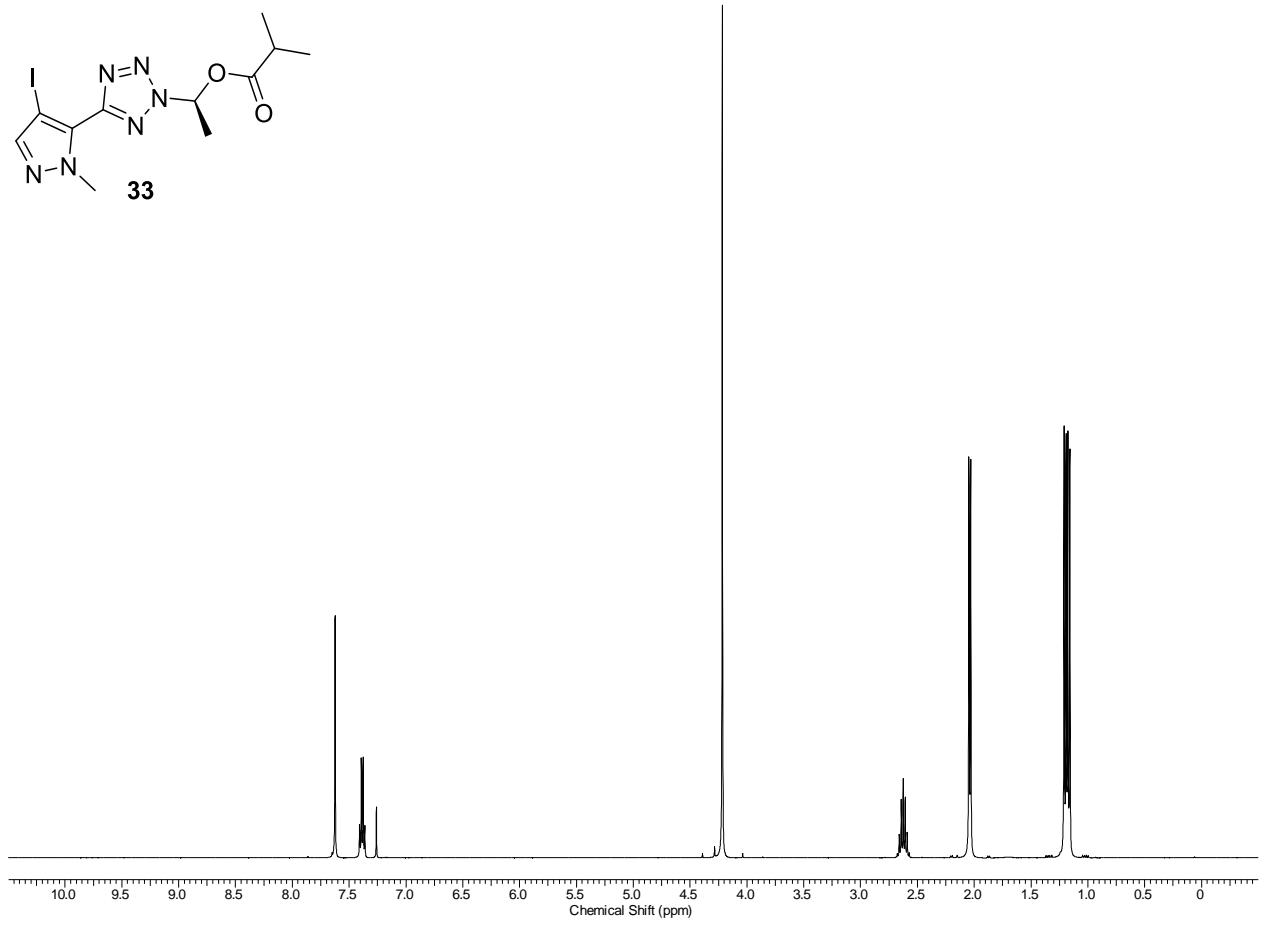

${ }^{1} \mathrm{H} \operatorname{NMR}\left(\mathrm{CDCl}_{3}, 25{ }^{\circ} \mathrm{C}\right)$

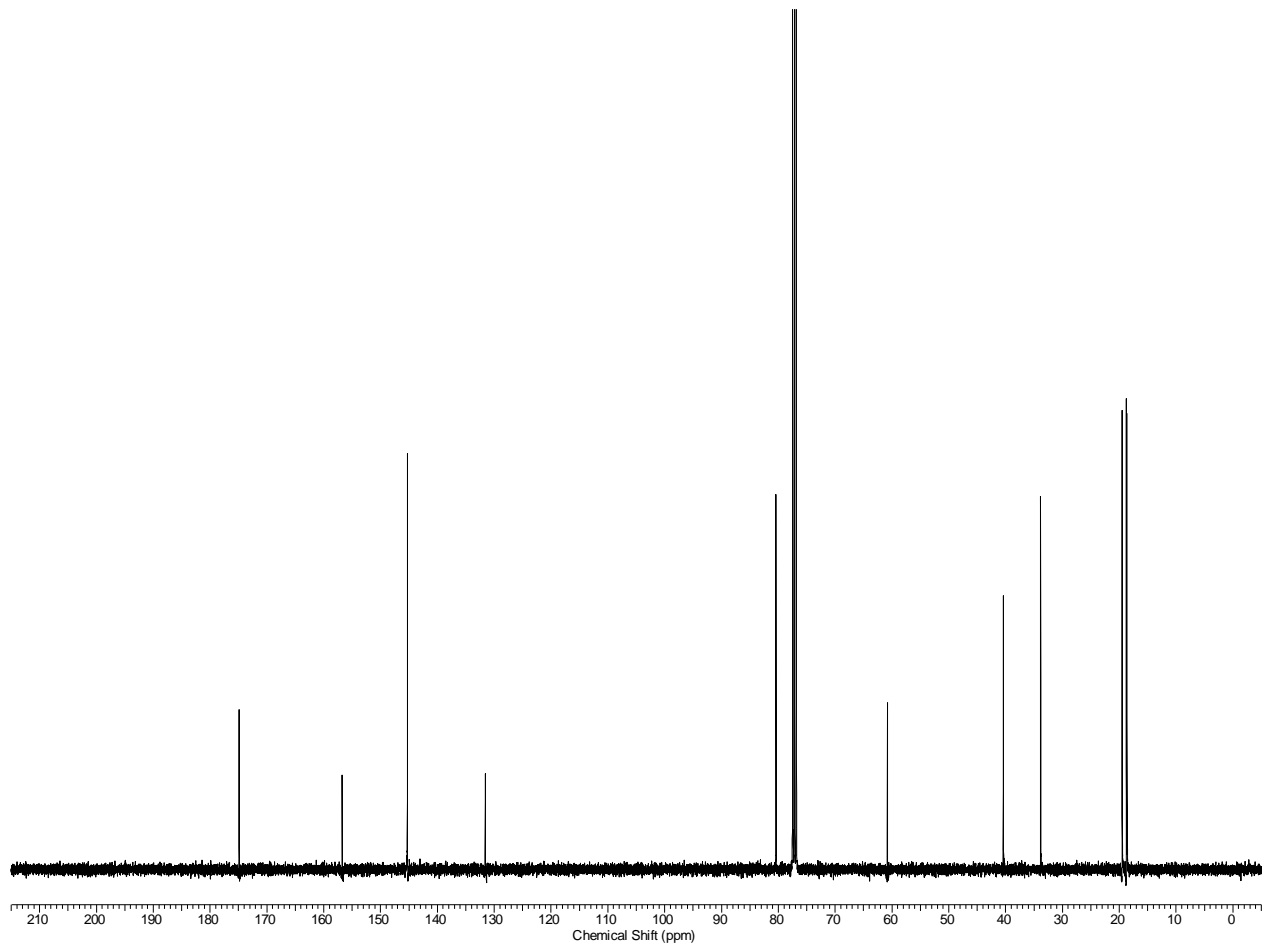

${ }^{13} \mathrm{C}$ NMR $\left(\mathrm{CDCl}_{3}, 25{ }^{\circ} \mathrm{C}\right)$ 


\section{References}

1) Fulmer, G. R.; Miller, A. J. M.; Sherden, N. H.; Gottlieb, H. E.; Nudelman, A.; Stoltz, B. M.; Bercaw, J. E.; Goldberg, K. I. Organometallics 2010, 29, 2176.

2) Darout, E.; Dullea, R.; Hawkins, J. J. L.; Londregan, A. T.; Loria, P. M.; Maguire, B.; McClure, K. F.; Petersen, D. N.; Piotrowski, D. W. PCT Int. Appl. (2014), WO 204170786.

3) Koren, A. O.; Gaponik, P. N. Int. J Chem. Kinet. 1993, 25, 1043-1051. 